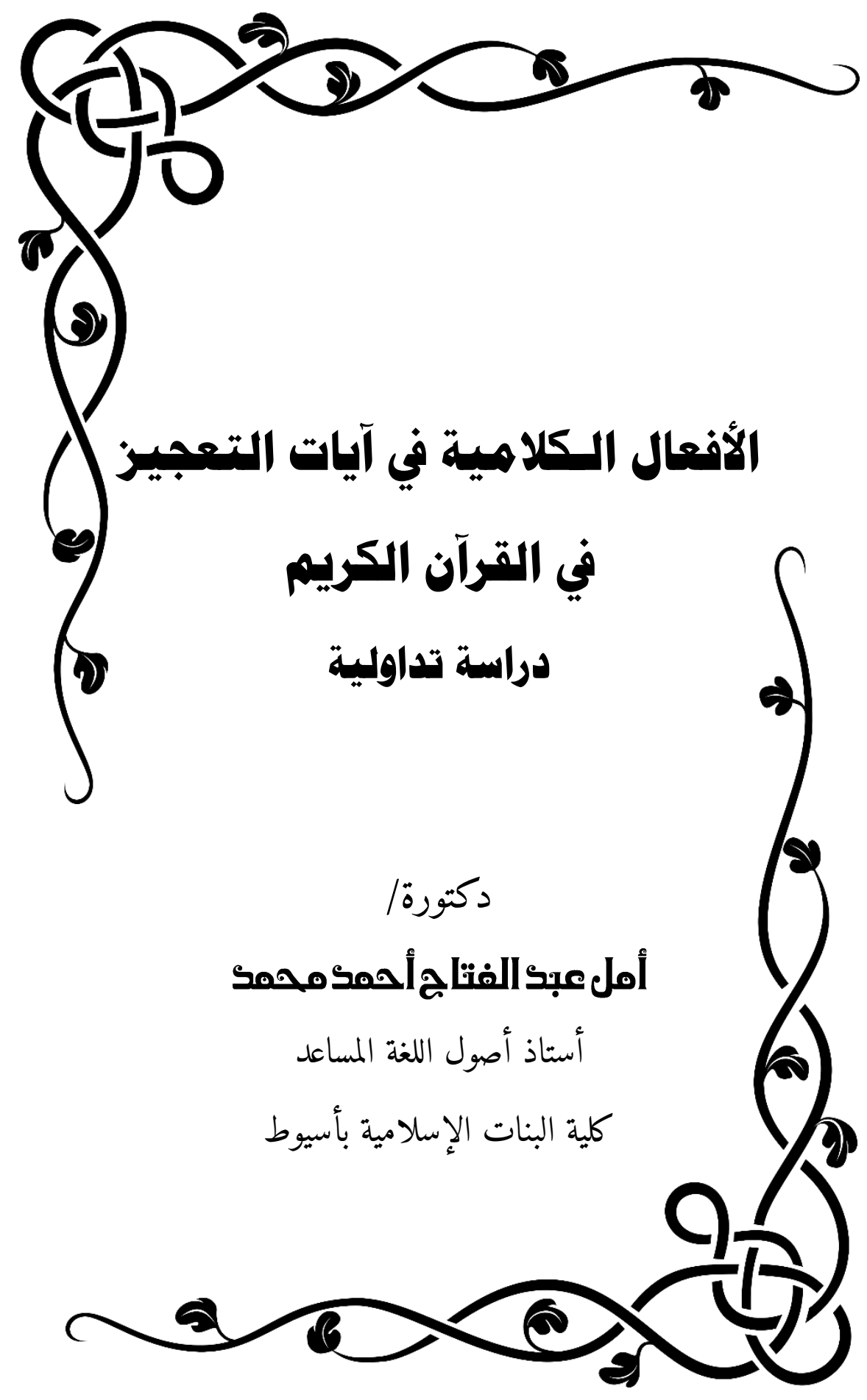


الأفعال الكلامية في آيات التعجيز في القرآن الكريم

\section{دراسة تداولية}

أمل عبد الفتاح أحمد محمد

قسم اللغة العربية، كلية البنات الإسلامية بأسيوط ، جامعة الأزهر ، جمهورية مصر العربية.

البريد الإكتروني: . Amlmohammed1376.el@azhar.edu.eg

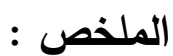

يتناول هذا البحث الأفعال الكلاميـة في آيـات التعجيز في القرآن الكريم: دراسة تداولية.

وقد جاء البحث في قسمين: قسم نظري، وقسم تطبيقي، أمـا القسم النظري فقد مَهدتُ فيه بالحديث عن مفهوم: التداولية والأفعال الكلامية، أمسا القسم التطبيقي، فكان البحث في دراسة الفعل الطلبي (الأمر ، الاستفهام) في آيات التعجيز ؛ وذلك بوصفه فعلاً لغويًا غير مباشر يحمل طاقة إنجازيـة الغرض دران منـه التلميح إلى عدد من الدلالات والمقاصد، مستخدمة المنهج الوصفي التحليلي، مستعينة ـ بالله ـ على تحقيق ذلك بما أبدعه علماء التفسير واللغة في تحليلهم للآيات القرآنية (موضوع البحث)، فَخُلَص البحث إلى تجليةِ ما تلمح إليه آيات التعجيز بتلك الأفعال، وبيان الأبعاد التداولية لذلك التلميح؛ ابتغاء الوقوف على قواهـا الإنجازيـة وأثره في النفس، طلبًا لخدمة الأهداف والمقاصد الدينية والتشريعية. الكلمـات المفتاحيـة: الأفعـال الكلاميـة ـ التداوليـة ـ أسـلوب الأمـر ـ أسـلوب

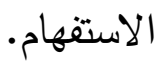




\section{The Verbal Acts of the Verses of the Miracles in the Holy Quran are a Deliberative Study}

\section{Amal Abd El-Fattah Ahmed Mohamed}

Department of Arabic Language, Faculty of Islamic Girls in Asyut, Al-Azhar University, Arab Republic of Egypt.

Email: Amlmohammed1376.el@azhar.edu.eg.

\section{Abstract :}

This research deals with the verbal acts of the verses of the Qur'an: a deliberative study.

The research came in two parts: a theoretical section, and an applied section, but the theory paved the way for talking about the concept of verbal and deliberative actions, and the applied section, so the research came to study the application act (order, question) of the verses of the obstruction; as an indirect linguistic act that carries an accomplished energy intended to hint at the number of using the descriptive analytical approach, using this to achieve this, which was created by the scholars of interpretation and language in their analysis of Qur'anic verses, the research concluded that the verses of the abrogation of these acts were manifested, and the deliberative dimensions of that insinuation were demonstrated, in order to identify their achievement forces and their impact on the soul, to serve religious and legislative objectives and purposes.

Keywords: Verbal, deliberative, Style of command, Questioning style. 


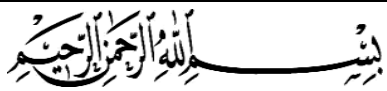

\section{المقدمة}

الحمـــــ لله رب العـالمين، والصــلاة والسـلام على سـيدنا محمــ النبـي الأمين، وعلى آلـه وصـحبه، ومـن اهتدى بهديـه وسـار على دربـه إلى يـوم

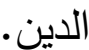

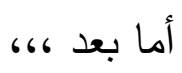

فإن اللغة سلوك اجتماعي يعبِّر به الناس عن أفكارهم، ونشاط تقوم به جماعة من الناس بهدف التواصل وتحقيق المصالح، والفرد يستخدم اللغة في مواقف الحياة حين يوجـه شكرًا، أو يقدم اعتذارًا، أو يصدر قرارًا، فـالكلام المصاحب لهذه الأنشطة وغيرها، هو مادة صالحة للدراسة(').

لذلك عُنيت بالدراسة والاهتمام من طرف العديد من التخصصات كعلم النفس، وعلم الاجتماع، والبنية، وهذه الأخيرة تنظر إلى اللغة على أنها بنية مغلقة، فقد شهد العقد السـابع مـن القرن العشرين منعطفًا جديدًا في الفكر اللغوي الحديث والمتمثل في التداولية التي ظهرت على يد (أوستين) وطوَّرها تلميذه (سـيرل)، وقد جـاءت كردّ على البنيويـة التي أهملت المعنى عامـة والكلام خاصـة كما حدث عند (دي سوسير)، والتركيز على الكفاءة وإهمال الأداء كمـا حدث عند (تشومسكي)، وهـي بـدورها أعـادت الاعتبـار للكـلام والأداء من خلال دراسة اللغة في علاقتها مع مستعمليها، إضـافة إلى كيفية فهم النـاس بعضـهم لبعض، وتنطلق التداوليـة مـن قاعدة أساسية هي "أننـا

( (1) الأفعال الكلامية في القرآن الكريم (سورة البقرة: دراسة تداولية)، محمد مدور ، (رسالة

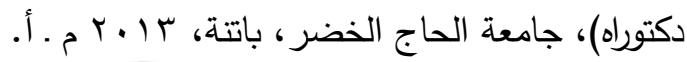




\section{الأفعال الكلامية في آيات التعجيز في القرآن الكريدردراسة تداولية}

عندما نتلفظ بقول فإنتا ننجز فعلاً كلاميًا في الواقع"، فهذا الاتجاه قد أتاح

للمستمع الكشف عن مقاصد المتكلم في مختلف المقامات('). هذا وتعد "نظرية الأفعال الكلامية" أهم نظرية في اللسانيات؛ حيث إن دراسة هذه الأفعال وما يفعله المتكلمون باللغة من تأثير وتبليغ وإنجاز أفعال

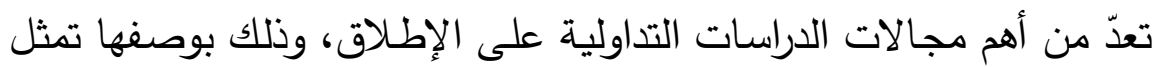
البنية الصغرى التي يتعين تحليلها والوقوف على طبيعتها قبل الانتقال إلى البنيـة الكبـرى التي تتمثـل في مختلـف أنـواع التبـادل فـي مجتمـع مـن

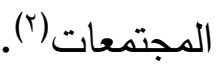

ومـن هـا المنطلق كـان اختيـاري لهـا البحـث الـذي جـاء عنوانـه:

(الأففال الكلامية في آيات التعجيز في القرآن الكريم: دراسة تداولية).

وأهم ما سأركز عليه في هذه الدراسة هو إسقاط هذه الأفعال الكلامية التي تمثل محور النظريـة التداولية والإنابـة في هذه النظريـة والتي تحساول الجمع بين التركيب والدلالة والسياق، وتعمل على استثمار الظروف المحيطة على نصــوص آيـات التعجيـز في توضـيح المعـاني المطلـوب إيصـالها للمخاطب ووصفها وتحليلها، ثم إبراز مدى تأثيرها في الخطاب ودورها في عملية التواصل والإببلاغ.

(1) أفعـال الكـلام في سورة مـريح: دراسـة تداوليـة، صباح حدادي، وسوسـن بوغداس،

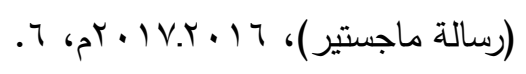

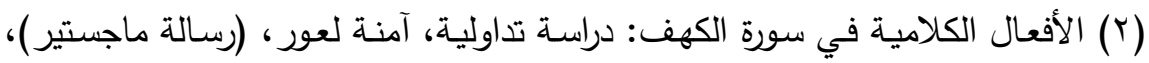

$$
. \wedge \text {, } r \cdot 11 . r \cdot 1 \cdot
$$




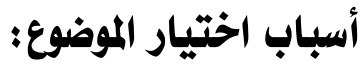

وأمسا عن سبب اختياري لهذا الموضوع، فهنالك أسباب ذاتية وأخرى

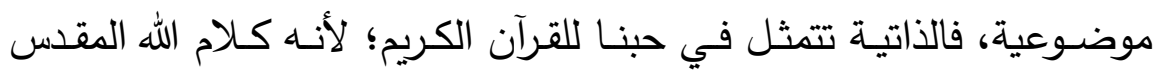

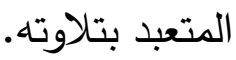

أما الأسباب الموضوعية فتتمثل في:

ا. العلاقة الوطيدة بين الدراسات اللغوية والقرآن الكريم؛ جعلت الكثير من

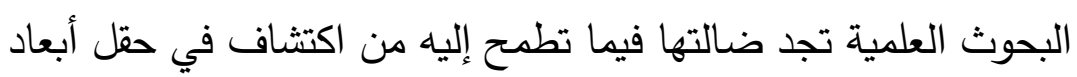

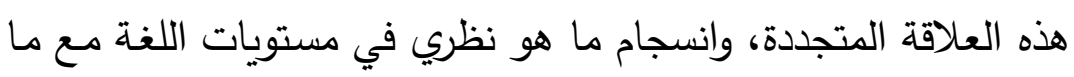
هو تطبيقي في نصوص الآيات القرآنية.

r. أن القرآن الكريم يحفل بالكثير من الأساليب التي خرجت عن معناها

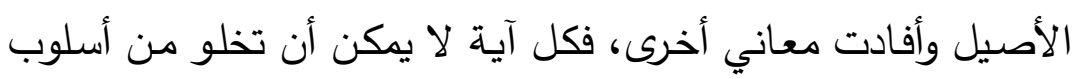

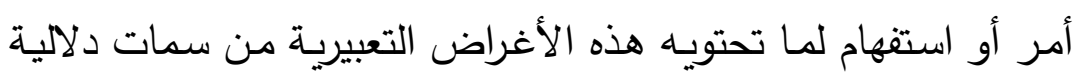

$$
\text { توحي بالمعاني المقصود إيرادها. }
$$

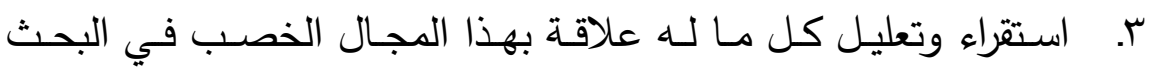

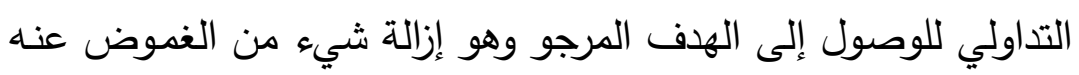
والتعق أكثر فأكثر في فهم المراد من الآيات الكريمة.

ع. الكثف عن أهية أفعال الكلام في العملية التبليغية التواصلية هذا من حن

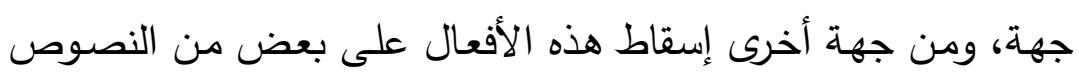

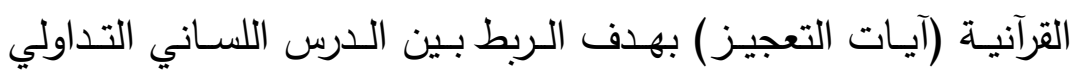

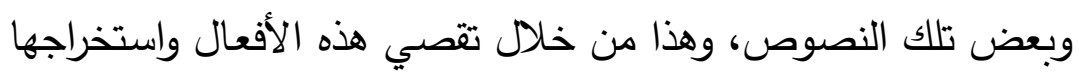
ودراستها بشيء من الوصف والتحليل. 


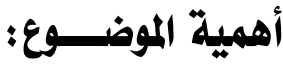

ا. كون القرآن الكريم في نظمه نمطًا واحدًا في القوة والإبداع؛ لأنهـ منزل

$$
\text { من الله . سبحانه وتعالى .. مورن }
$$

r. ما انفردت به آيات التعجيز من خصائص تفردت بها عن باقي الآيات، كالإكثار من أساليب الترغيب والترهيب، والوعد والوعيد، والثدة واللين، وتضمنها لقصص الأقوام السابقة، وأصحاب الجنة والنار وغير ذلك. ب. أن البحث يمثل جانبًا تطبيقيًا للـون مهم مـن ألـوان التداوليـة، وهـو

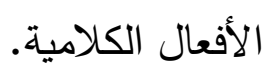

ع. استخراج الأفعـال الكلاميـة الواردة في آيـات التعجيز على اختلافها، للوصول إلى معنى المعنى منها.

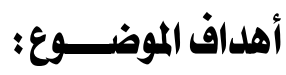

يمكن تلخيص الأهداف المرجوة من البحث، فيما يأتي:

1. التأصيل لظاهرة الأفعال الكلامية على مستوى التتظير والتطبيق، باحثة عن منطلقاتها، كاشفة عن أسسها، محاولة الإجابة عن التساؤلات التي يفرضها الموضوع. r. السعي إلى إيجاد مقاربة بين التراث اللغوي والمناهج البحثية الحديثة، وربط جسور التواصل المعرفية بين الجميع. r. الثرعية في بيان البعد التداولي الوظيفي على وجه العموم، وفي ظاهرة

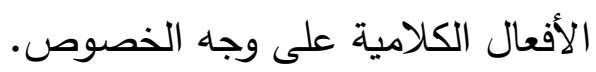




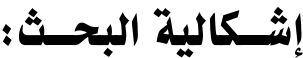

بناءً على ما سبق، جاز أن نتساءل حول ظاهرة الأفعال الكلامية:

1. هل هي ظاهرة لا تحمل إلا الجانب اللفظي/الهصطلحي منه؟ أو بعبارة

أخرى: هل الأفعال الكلاميـة مـا هي في جوهرهـا إلا اكتثـاف لصـرح

أثري عظيم عكف اللغويون عليه ببراعة فائقة؟

r. ماذا تحمل هذه الظاهرة في طياتها من عوامل تشير بتطور موضوعي؟ وكيف السبيل إلى فهم تلك المقاصد، وكيف يمكن فك ذلك التشـابك

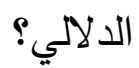

r. هـل ظـاهرة الأفعال الكلاميـة ظـاهرة عربية في حد ذاتها لها جانبها النظري والتطبيقي معًا؟ أم هي مجرد أفكار ومناهج غربية، طبقت على

$$
\text { نصوص عربية؟ }
$$

ع. هـل تعـدد مقاصــ الأفعـال الكلاميـة لتعـد صـيغها،مراعاة السـياقات

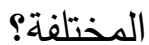

ه. ما مدى وظيفة الأفعال الكلامية في توجيه المعنى لآيات التعجيز في

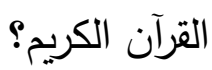

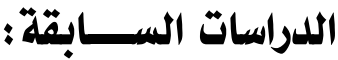

لم أقف ـ في حدود بحثي ومطالعتي . على تـاول بحث مفرد لهذا الموضـوع، كمـا لـم أعثر على رسـالة علميـة تتاولت هذا الموضـوع دراسـة تداولية، وإنمـا الذي عثرت عليه يتمثل في مجموعـة رسـائل علميـة تناولت 


\section{الأفعال الكلامية في آيات التمجيز في القرآن الكريم دراسة تداولية}

سورًا من القرآن الكريم في جملتها غير متعرضـة لآيات التعجيز بالتحديد إذا وجد فيها، وقد لا يوجد، ومن هذه الرسائل:

ا. رسـالة ماجستير، لآمنـه لعـور، بعنـوان: "الأفعـال الكلاميـة في سورة

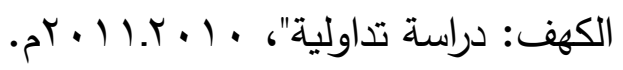

r. رسالة دكتوراه، لمحمد مدور ، بعنوان: "الأفعال الكلامية في القرآن الكريخ

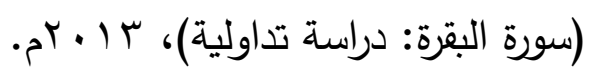

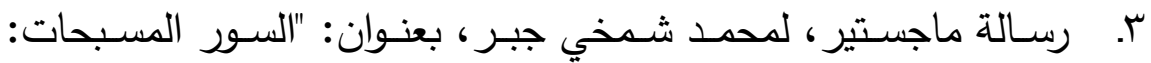

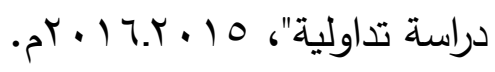

ع. رسالة ماجستير ، لصباح حدادي، بعنوان: "أفعال الكلام في سورة مريم:

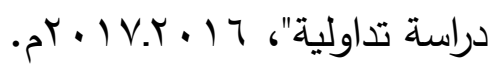

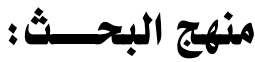

وقد اعتمدت في هذا البحث على المنهج الوصـي التحليلي؛ لأنسه الأنسب لهذه الدراسـة العلمية، وما يتبع المنهج من تحليل وتقرير واستتباط،

$$
\text { وذلك من خلال ما يلي: }
$$

ا. جمع الآيـات القرآنيـة المتعلقـة بموضـوع البحث وكتابتها، وعزوهـا إلى سورها في ضوء مصحف المدينة المنورة.

r. توزيع الآيات القرآنية التي تمّ جمعها إلى مقاصد حسب موضوعاتها في مباحث البحث ما أمكن.

r. الرجوع إلى كتب التفاسير القديمـة والحديثة، وتحليل الآيـات المتعلقـة بموضوع الدراسة والبحث في ضوء هذه النظرية. 
ع. شـرح الألفـاظ الغامضــة، وبيـان معانيهـا مسـتعينة في ذلـك بالكتب المتخصصة وأمهات المعاجم اللغوية.

ه. عرض آراء وأقوال العلمـاء المتعلقـة بالجزئيـة المدروسـة من مصـادرها الأصلية ومناقشتها وإبداء الرأي فيها.

T. بيـان السياق العـام والتحليل التداولي للآيـات، مـع محاولـة الربط بين الأفعال الكلامية وبين مقصود الآية ما أمكن ذلك.

\section{الصعــاب:}

ولم تكن مهمتنا في هذا العمل بمنأى عن الصسعاب والعوائق التي يتقدمها تعذر الحصول على مادة علمية متُبلورة بمنهج قائم بذاته في التراث اللغوي العربي، وخاصـة فيما يتعلق بالجانب التداولي، هذا من جهة، ومن جهة أخرى، فإن الوقوف على المعنى والسياق ما يزال يحتاج إلى قراءات عميقة، قراءات تقوم على فهم العلاقات الدلالية والسياقية في آيات الخطاب القرآني، وهو ما قد يكون واحدة من أكثر القضـايا صعوبة في هذا البحث، من جهة أن دلالة التعجيز في آيات القرآن الكريم تقوم على اعتبار دلالي تركيبي، وفهم عميق لبنية المعنى فيها والسبب من صعوبة هذا الأمر •

\section{خطة البحـــــ}

وقد مكَّن هذا المنهج من توجيه مسار خطة انتظم وفقها هذا البحث،

$$
\text { والتي تألفت من جانبين: }
$$

ا. الجاتب النظري: وتألف من مقدمة وتمهيد.

r. الجانب التطبيقي: وتألف من أربعة مباحث. 


\section{الأفعال الكلامية في آيات التمجيز في القرآن الكريم دراسة تداولية}

ففي المقدمسة: تتاولت أسباب اختيار الموضـوع، وأهميته، وأهدافـه، وإشكالية البحث، والدراسات السابقة، ومنهج البحث، وصعوبته. التمهيد: وعنوانه: "حدود المعاني للتداولية والأفعال الكلامية في آيات التعجيز"، وهذا ما جعلني أقسمه إلى ثلاثة عناصر تتمايز بمعانيها اللغويـة، وتبرز بعض ملامح اشتراكها مع النظرية التداولية، فتناول:

أولاً : التداولية: مفهومها ـ نشأتها ـ تطورها. ثانيًا : الأفعال الكلامية. ثالثًا : مفهوم التعجيز عند علماء اللغة.

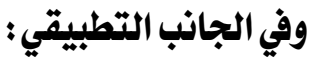

المبحث الأول: بعنوان: الأثر التداولي لأفعال الكلام في أسلوب الأمر. المب -جث الـ ـثاني: بعنوان: الأثر التداولي لأفعال الكلام بصيخ مخصوصـة لكلأمر . المبحث الثالث: بعنوان: الأثر التداولي لأفعال الكلام في أسلوب الاستفهام.

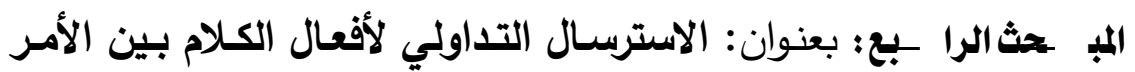
والاستفهام.

الخاتمة: وقد جمعت فيها أهم النتائج العامة التي تراءت لي أهميتها والتي تتفق ومضـمون البحث وتبين خصوصيته العلمية، مـع تسجيل أبرز توصيات البحث.

اللهم نسألك التوفيق في المسعى، فأنت الموفّقُ مسدِّد الخُطى إلى ما فيه صلاحنا حتى ترضى، فلك الحمد عند الرضا، ولك الحمد بعد الرضا. وآخر دعواي أن الحمد للّه رب العالمين

الباحثة 
التمهيد

حلود المعاني للتداولية والأففال الكلامية في آيات التمجيز

أولاً ــ التداولية . . مفهومها .. نشأتها وتطورها :

ـ التداولية ـ مفهومها (لفةً واصطلاحًا) :

لغة تعني: التحول من مكان إلىى مكان، قال ابن فارس: "الََّّالُ وَالْوَاوُ

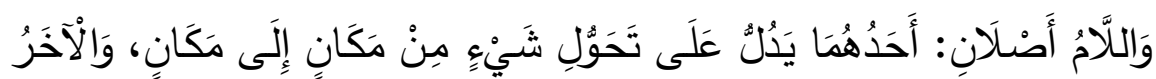

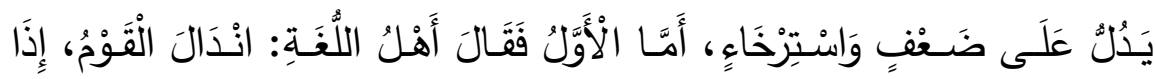

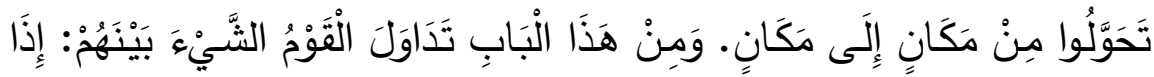

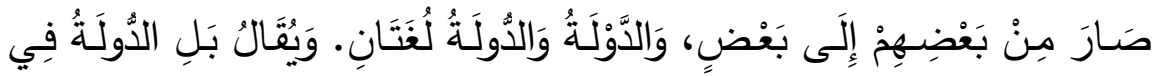

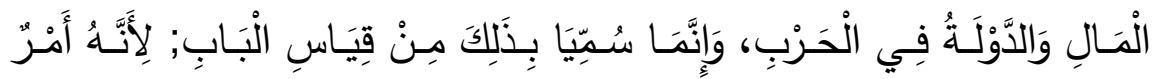

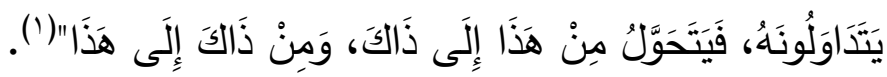
وقد أفاد اللغويون من المعجم القرآني في استشراف هذه المادة ولاسيما (التداولية)، ومن الشواهد القرآنيـة التي وردت فيها التداولية بمعناهـا اللغوي

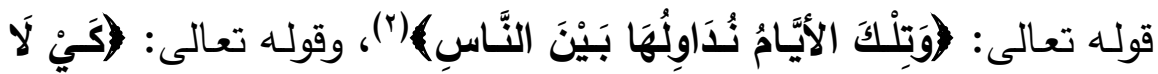

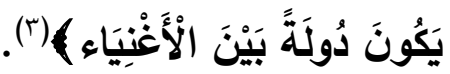


يتبين من الآيـات المباركات أنَّ التداول يأتي بمعنى التحول وعدم الثبوت؛ فهي لا تختلف كثيرًا عن معناها اللغوي؛ إذ يفهم منها انتقال الملك الك

$$
\text { والتعاقب والتتاوب على أمرٍ ما('). }
$$

اصطلاحًا : لقد اختلف علماء اللغة في تعريف التداولية نظرًا لاتساع مجالها المعارفي الذي يتشابك بالعديد من العلوم مما أدَّى إلى صعوبة وضـع تعريف خاص بها يلم بآفاقها وانشغالاتها (؟).

ومن أقدم التعريفات الاصطلاحية التي جرت على التداولية ما ذكره (شارلز موريس) عام مبه (م؛ حيث يدل على فرع من فروع ثلاثة يشتمل

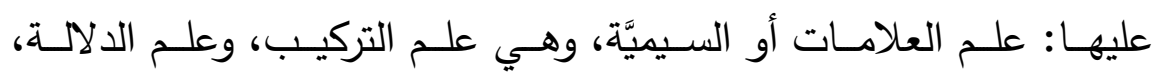
والتداولية، وهي فرع لساني يعنى بدراسـة التواصل بين المتكلم والمتلقي، أو

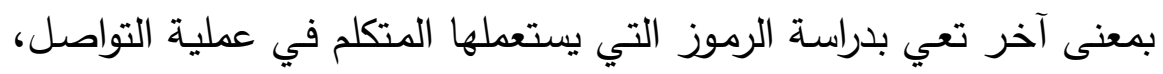

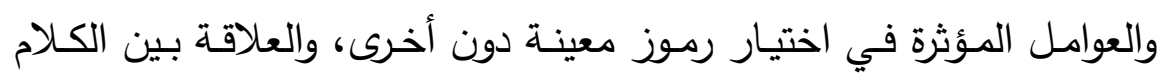
وسياق حاله، وأثز العلاقة بين المتكلم والمخاطب في الكلام(ب). فهي:" فرع من علم اللغـة يبحث في كيفية اكتشـاف مقاصد المتكلم (Speaker meaning) فقول القائل: أنا عطشان مثلا قد يعني: أحضر لي كوبًا من الماء، وليس

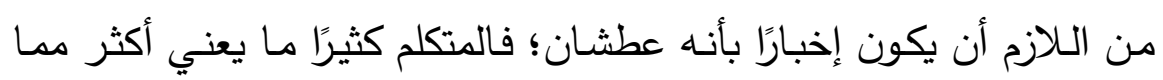

(') الفعل الكلامسي في سورة الأنفال، قراءة تداولية، حسين جعفر عبيد، جامعة بابل

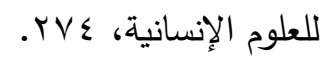

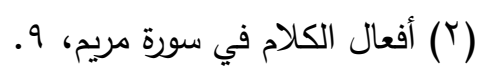

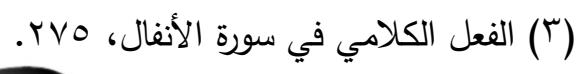


تقولـه كلماتـه، وإذا كـان ذلك كذلك فكيف يمكن للنـاس أن يفهم بعضـهم

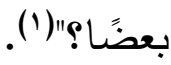

أنها "دراسـة جوانب السياق التي تُشَفَّر شكليًا في تراكيب اللغة، وهي

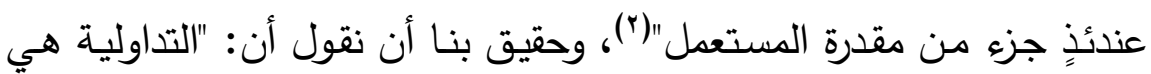
دراسـة المعنى الذي يقصده المتكلم ... التداولية هي دراسـة المعنى السياقي ... هي دراسة كيفية إيصال أكثر مما يُقال"(").

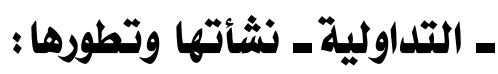

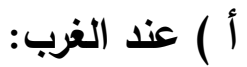

يظن بعض الباحثين في الدرس اللغوي المعاصر أن نشأة التداولية جاءت نتيجة أعمال فلاسفة اللغة المنتمين إلى التراث الفلسفي في جامعـة أكسفورد، وهم جون أوستين (J.L. Austin)، وجون سيرل (J.R. Searle) وجرايس (H.P.Grice).

(1) السور المسبحات: دراسـة تداولية، محمد شمخي جبر ، (رسالة ماجستير)، 10 • ب.

$$
\begin{aligned}
& . V 6 r \cdot 17 \\
& \text { (r) السور المسبحات، V. }
\end{aligned}
$$

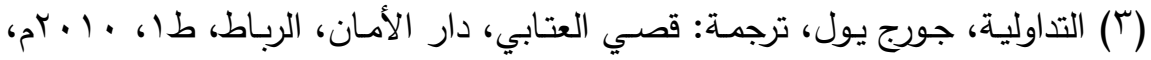




\section{الأفعال الكلامية في آيات التعجيز في القرآن الكريدر دراسة تداولية}

إلا أن البحث في أصول التداولية يصل بنا حقيقة ترجح أن الأرض التي نبتت عليها التداولية هي الفلسفة التحليلية؛ لأنها الينبوع المعرفي لأول

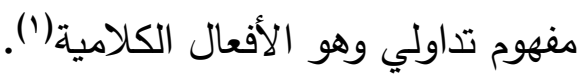
في بـدايات القـرن العشـرين ظهـر اتجــاه فلسـي بزعامـة الفيلسـوف

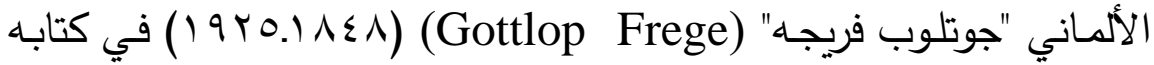
"أسس الحساب" ميَّز فريجه في كتابه بين مقولتين لغويتين تتباينان مفهوميًا ووظيفيًا وهما: اسم العلم والاسم المحمول، وعماد القضية الحملية. وحين تكون القضية دالة على علاقة واحدية نسميها قضية حملية، وحين تدل على العلاقات الأخرى نسميها قضية علاقية وليست حملية"(؟). لقد ميَّز الفيلسوف الألماني "فريجـه" بين اسم العلم والاسم المحمول، ومن الأمور التي ميز بينها هذا الفيلسوف تمييزه بين المعنى والمرجع محدثًا قطيعة معرفية ومنهجية بين الفلسفتين القديمـة والحديثة، كما أنها جمع بين بعدين تداوليين مهمين هما الإحالة والاقتضاء"("".

واعتبر الألفاظ (كل وبعض، وواحد، واثنان) لا معنى لها إذا دخلت على علَم، بل العكس؛ فعند دخولها على علَم قد تفسد، فلا يمكن القول: كل محمد، أو بعض محمد، أما إذا دخلت على محمول فإنها تأتي بمعنى جديد

(') التداولية عند العلماء العرب: دراسـة تداولية لظاهرة (الأفعال الكلامية) في التراث اللساني العربي، د. مسعود صحراوي، دار الطليعة، بيروت، ه. . . Yم، V V. (Y) في فلمسفة اللغة، لمحمود فهمي زيدان، دار النهضة العربية، 910 ام، ب ال. (T) التداولية عند العلماء العرب، · بـ. 
فنقول مثلاً: كل متعلم، كل موظف، وتعد هذه المباحث عند الفلاسفة ذات

قيمة عالية، وتعد ثورة وانقلابًا فلسفيًا جديدًا (').

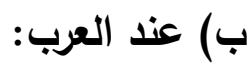

تميزت الدراسـات اللغويـة في التراث العربي بالاهتمام ببعض الجوانب

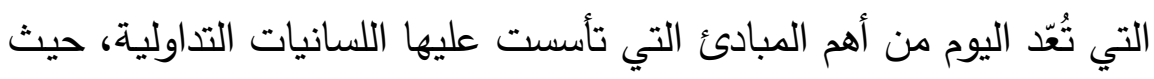
اهتم الدارسون القدامى بدراسة النص باعتباره خطابًا متكاملاً. متجاوزة بذلك مجرد وصف البنية والثكل النحوي وكل ما له علاقة بعملية التواصل اللغوي كما اهتمواُ بمعيار الصدق والكذب ومطابقة الخطاب للواقع وعدمهه ومراعاة. المقام ومطابقته لمقتضى الحال.

وتبدو هذه السمات التداولية واضحة المعالم في أعمال بعض الباحثين

$$
\text { القدامى، نحو: }
$$

الجاحظ (ت: ه ه هـ): فالبيان عند الجاحظ هو : "اسم جامع لكل شيء كثف لك قناع المعنى، وهتك الحجاب دون الضمير، حتى يفضسي السامع إلى حقيقته، ويهجم على محصوله كائنًا ما كان ذلك البيان، ومن أي جنس وهن كان الاليل؛ لأن مدار الأمر والغاية التي يجري إليها القائل والسامع إنما هو الفهم والإفهام. فبأي شيء بلغت الإفهام وأوضـت عن المعنى، فذلك هو

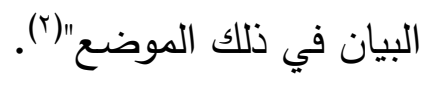

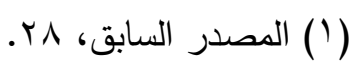

(Y) البيان والتبيين، الجاحظ، تحقيق: عبدالسـلام هارون، دار الهلال ـ بيروت، (د.ط)،

$$
.11 / 1 \text { (ه) }
$$




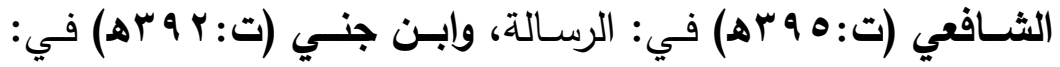
الخصائص، وأحمد بن فارس (ت:0 9 وه) في: فقه اللغة وسنن العرب في كلامها، والزمخثري (ت:^ بههـ) في: الكثاف. كما تبدو هذه المبادئ في أعمال:

السكاكي (ت: 7 ب 7هـ): فقد بدت ملامح الاتجاه التداولي في أعماله، واهتمامه بعناصر العملية التواصلية وربطها بمقتضى الحال، ويرى أنه لكل من هذين الطرفين (المتكلم/ المتلقي) دور فعال في تحديد المقصد وتبليغه وله وفهمه.

هذا إلى جانب بعض الأعمال الحداثية من مثل:

طـــه عبـــالرحمن الـذي قـام بوضــع مصـطلح (التداوليـة) كمقابـل

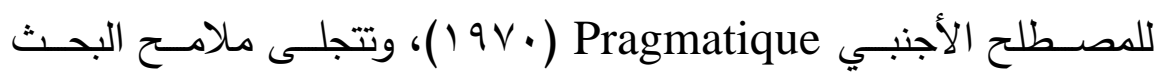
التداولي عنده من خـلا اهتمامسه بالكلام والعملية التخاطبية ككل، إذ يقول في هذا الصدد: "ولمّا كان التخاطب يقتضي اشتراك جانبين عاقلين في إلقاء الأقوال وإتيان الأفعال لزم أن تتضبط هذه الأقوال بقواعد تحدد وجوده فائدتها

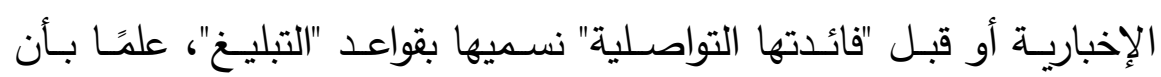
مصطلح "التبليغ" موضوع للدلالة على التواصل الخاص بالإنسان" ('). أما "أحمد المتوكل" فيُعدّ من أبرز ممثلي الاتجاه التداولي.

(1) اللسان والميزان أو التكوثر العقلي، طه عبدالرحمن، المركز الثقافي العربي، الدار

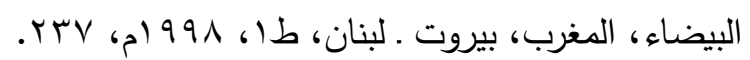


ومهما يكن من أمر فيمكن إجمال ما تقدم بالقول: إن التداولية منهج في تحليل الخطاب تبحث عن كل ما من شأنه أن يقرِب الفهم والتواصل بين

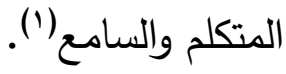

\section{ـ المفاهيم الأساسية للتداولية:}

تأسسـت التداوليـة على مفـاهيم كثيـرة، ســـتقي بأهمهـا حتى يمكِن للدارس من التعرف على المنهج التداولي ونظرّياته، وهي: ا. الفعل (Acte): حيث إن اللغة تتجلى في كونها نشاطًا عمليًا يسعى إلى تحويل الملفوظات إلى أفعال لها وضعيتها الاجتماعية، والكلام هو تحقيـق الأفعـال مسـيَّة وفـق مجموعــة مـن القواعـد مـن شـــنها تغييـر معتقداته ووصفه السلوكي لما تمارسه من تأثير (ז)، ويترتب على ذلك ملك أن فهم قول معين يعني التعرف بمحتواه الاجتماعي وتوجهه التداولي، أي قيمته وقوته الكلامية فيما يسمى عبارات مؤدية. r. السياق (Context): يتضح السياق في مقدمة مفاهيم التداولية حسب تصــنيف (فرانسـواز أرمينكـو)، والمـراد بالسـياق: مجموعـة الثـروط الاجتماعية (الموقف الفعلي) التي تأخذ بعين الاعتبار دراسة العلاقات الموجـودة بـين السـلوك الاجتمـاعي واسـتعمال اللغـة، وهـي المعطيـات

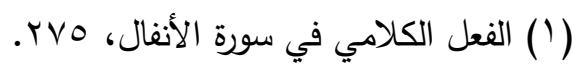

(Y) في تداولية الخطاب الأدبي (المبادئ والإجراء)، نواري سعودي أبو زيد، بيت الحكمة

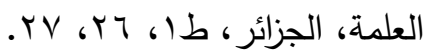


المشتركة بين المرسل والمتلقي والوضعية الثقافية والنفسية، والتجارب

والمعلومات الثائعة بينهما (').

\section{ـ التداولية وعلاقتها بالأففال الكلامية ؛}

"ولفظــة التـداول تفيـد في العـــم الحـديث الممارسـة، ويعبـر عنهــا بـ(LAPRASCIS) والتـي تفيـد تمــام الدراسـة، وتفيـد أيضًّــا التفاعـل في التخاطب...."(؟). (والخطابات التوجيهية تخرج من إطـار التناوب في أخذ الكلمة، ذلك بأنها تجعل المتلقي للخطاب محل طرف مالك المعارف، أمـا الطـرف المتلقي فمـا عليـه إلا الأخـذ أو الاسـتماع وعليـه يتبلـور مصـطلح التداولية كممارسة ويعني امتلاك اللغة وجريـان الكلام على الألسن، أي من التلفظ ذاته كعملية خاصـة بالفرد والتي تتجلى في ممارسة اللغة إلى هدف إيصـال الرسـالة أو الخطـاب إلى المخاطب والتـأثير عليـه ضـــن عنصـر التفاعليـة، فـالتلفظ إذن أسـاس التداوليـة في الشـكل الظـاهري؛ إذ مـن دون الأولى لا تتحدد الثانية كعملية، وكلتا العمليتان تخضعان إلى عامل السياق، الإطار المجهول الذي نبحث عنه في تبعية الخطاب في غيابه، حتى نتمكن

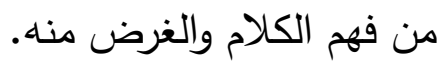

وعليـه، فإنـه كلمـا تـوفر المتلقي على معلومـات عن هذه المكونـات (المتكلم) الملتقي للرسالة، الزمان، والمكان، ونوع الرسالة، تكون له خطوط

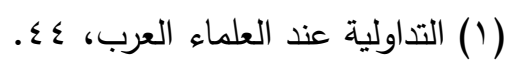

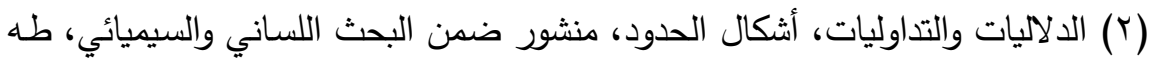

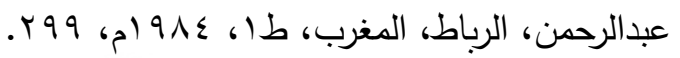


قويـة لفهم الرسـالة وتأويلها، أي وضـعها في سياق معين من أجل أن يكون لديها معنى (')

ثانيًا ــ الأفعال الكلامية :

\section{أ ) الأفمال الكلامية في الفكر اللساني الفربي:}

تُعدُّ الأفعال الكلامية من الموضوعات المهمة التي أسست لظهور علم

التداولية، وهي الأفعال التي يكون لها إنجاز دلالي يقتضيه المقام أو السياق، فيخرج الملفوظ من معناه الحرفي إلى معنى آخر هو المقصود من العملية التواصلية.

وظهر أثر نظريـة الاستعمال، أول مـا ظهر في مدرســة (كمبـردج) وخاصة في أعمال (أوستين)، ولاحقًا في أعمال فيلسوف اللغة (جون سيرل)

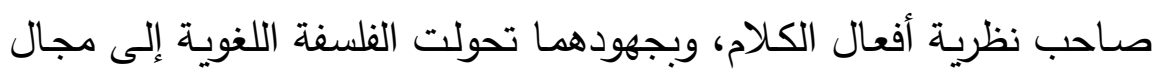
يبحث في مشكلات اللغـة(؟)، ولا يقول أوستين بالتقسيم التقليـي للقضـايا والجمل إلى خبريـة وإنشائية، وبالتالي الاحتكام إلى معيار الصدق والكذب، وإنما ينطلق من موقف جديد، وهو أن الوحدة الأساسية للغة، هي الأفعال الكلامية، وإذا اعتبرنا الأقوال أفعالاً فإنها تسعى لتحقق شئيًا ما، وبالتالي فإن إن

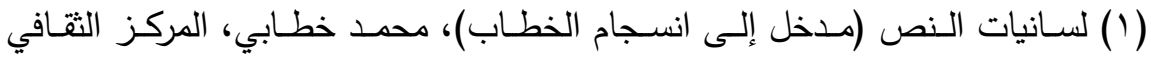

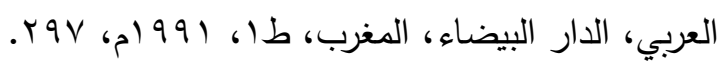

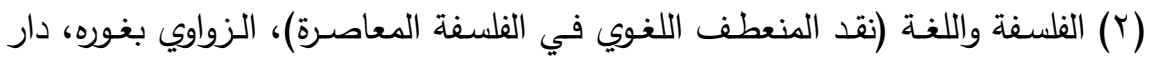

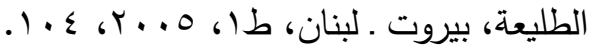




\section{الأفعال الكلامية في آيات التعجيز في القرآن الكريدر دراسة تداولية}

المسألة لا تتعلق بالصدق والكذب فقط، وإنما بالسياق والمناسبة التي تمّ فيها

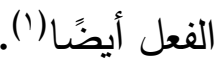

Speech إن مصطلح الأفعال الكلامية ترجمة للمقابل الإنجليزي acts، وحين نتحدث عن الفعل نقصد بـ الحدوث والوقوع، ومن ثمَّ إنجاز

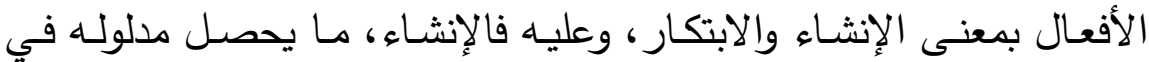
الخارج بالكلام، وهذا المعنى للإنشاء هو الذي يقدمه (أوستين)، فنحن ننجز الأثياء بالكلام، أي نخرجها من حيز العدم إلى الوجود(؟). "ومـن الضـروري أن لا يغيـب عـن ذي بـال أن فعـل الكـلام شـامل

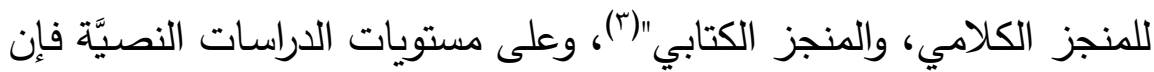
الفعل الكلامي يمثل التأكيد على أثياء، أو إعطاء أوامر، أو إثارة أسئلة، أو الو التئي القيام بوعود، أو غير ذلك من الأفعال التداوليـة التي تركز على تأويل التيل النصوص باعتبارها أفعالاً للغة: كالوعود، والتهديدات، والاستفهام، والطلبات.

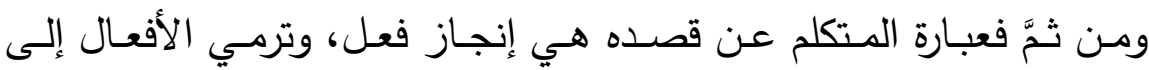

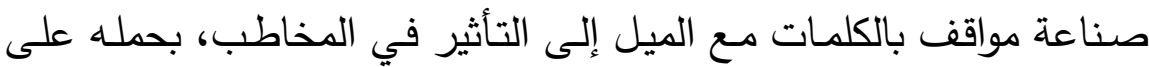
فعل، أو ترك، أو تقرير حكم، أو إبرام عقد، أو إفصاح عن حالة نفسية. إن النتائج الأولية التي توصل إليها أوستين في الخمسينيات خضعت

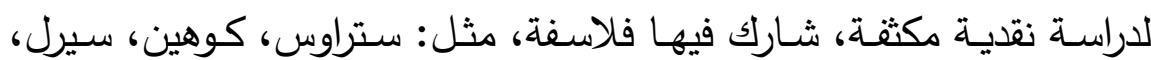

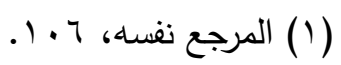

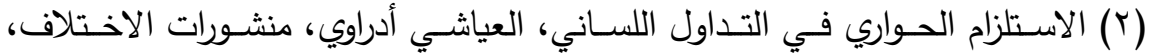

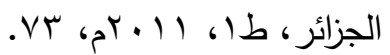

(ץ) محاضرات في المدارس اللسانية المعاصرة، نعمان بوقرة، منشورات جامعة باجي الماني

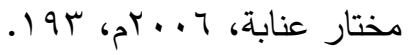


وفاندرفكن. "ويرى أوستين أن الأقوال ليست خالية من المعنى، ومن تحديد السمات المميزة لها، وأهم تلك السمات هي: ارتباطها بالمتكلم وبالموقف الذي تقال فيه، ومن ثُّ نحكم بأنها ملائمة أو غير ملائمة" ('). ثم راح أوستين يوسـع المفهوم ليشمل جميع الجمل، حتى تلك التي تقبل الصدق والكذب، فأنتج بذلك فلسفة عامة للغة، ثم مضى يثبت أن هناك

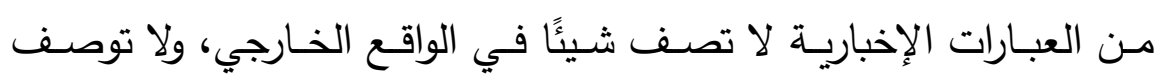
بالصدق أو الكذب، فهي إنشائية.

فمثلاً: إذا قيل لك: ما اسم مولودك؟ قلت: سميته يحيى، أو في جملة أخرى: أوصي بنصف مالي للجمعيات الخيرية، أو في عبارة: زوجتك ابنتي. فهذا النوع من الجمل إذا نطقت به فإنك لا تلقي قولاً، بل تتجز قولاًً) (؟). فـأطلق أوسـتين على هـذه الأفعـال مصــلح الأفعـال الإنجازيــة Performative الوصية، التزويج، الاعتذار، الترحيب، أو النصح ... إلخ). فهي لا توصف بصدق أو بكذب، بل تكون موفقة أو خائبة إذا راعى المتكلم شروط أدائها،

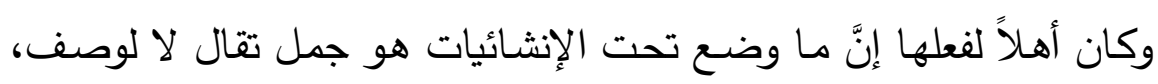
إنما التلفظ بها هو جزء دن القيام بفعل.

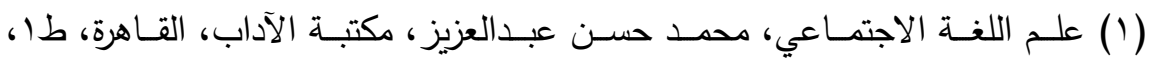

$$
\text { . T }
$$

(Y) نظرية الأفعال الكلامية بين فلاسفة اللغة المعاصرين والبلاغيين العرب، طالب سيد

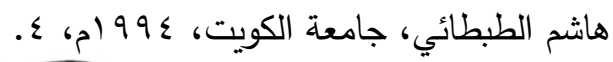




\section{الأفعال الكلامية في آيات التعجيز في القرآن الكريدر دراسة تداولية}

ولاحظ أوستين أن هذه الأفعال في اللغة الإنجليزية يستخدم معها غالبًا ضمير المتكلم مسندًا إليه، والفعل في صيغة المضارع المبنى للمعلوم، وقسم أوستين الأفعال الإنجازية إلى نوعين:

ا. إنشائيات صريحة مثل قولنا: آمرك أن تعرض عن الجاهلية.

r. إنشائيات ضمنية أولية مثل قولنا: اعرض عن الجاهلية(').

ولقد وجد أوستين أن الفعل الكلامي مركب من ثلاثتة أفعال تُؤدَّي في وقت التلفظ بالفعل، وهي: ( (. فعل القول، r. فعل متضـمن في القول، ؟r. فعل ناتج عن القول)، فهي ليست أفعالاً ثلاثة يستطيع المتكلم أن يؤديها واحدًا تلو الآخر، بل هي جوانب لفعل واحد(r)، مركب من ثلاثة أقوال: أ ) الفعل اللفظي: وهو يتألف من أصوات لغويـة تنتظم في تركيب نحوي صحيح ينتج عنه معنى محدد وهو المعنى الأصلي، وله مرجع يحيل إليه.

ب) الفعل الإنجازي: وهو ما يؤديه الفعل اللفظي من معنى إضـافي يكمن خلف الأصـلي، أو يعني بـه محاولـة المتحدث إنجاز غرض توضل تواصـلي

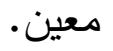

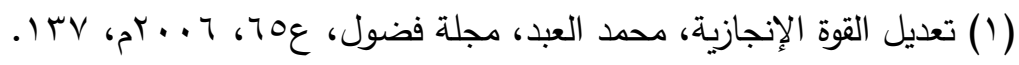

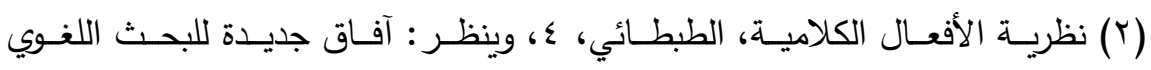

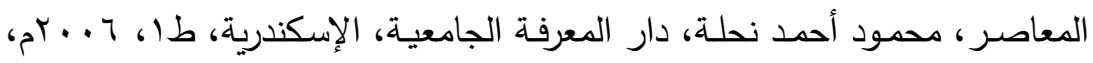


ج) الفعـل التـأثيري: ويقصــ بـه الأثر الـذي يحدثـه الفعـل الإنجازي في

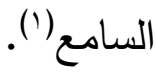

وعمد أوستين إلى تقسيم الأفعال الكلامية إلى نوعين:

1. أفعال إخباريـة (تقريريـة): وهي أفعال تصف حقائق العالم الخارجي، ويمكن الحكم عليها بالصدق أو الكذب، نحو: (السماء تمطر) فهي تنقل معلومـة إلى المتلقي أو تقرر واقعًا، وتوصف بالصـدق إذا كان المطر حادثًا، كما توصف بالكذب إذا كان المطر غير حادث. وقد سمَّي أوستين الجمل التي تحتوي على هذا النوع من الأفعال بـ(الجمل الوصفية) التي تصف حدثًا أو حالة معينة من دون حصول فعل.

r. أفعـال إنثــائية (أدائيـة): تُؤََّّي بها أفعـال في ظـروف ملائمـة، ولا توصـف بصـدق ولا كذبٍ، وإنمـا تكون ناجحـة، طبقًا لمعيـار الموائمــة والمخالفة، وكون المتكلم مؤهلاً للقيام بالفعل، نحو: (أوصسي بساعتي

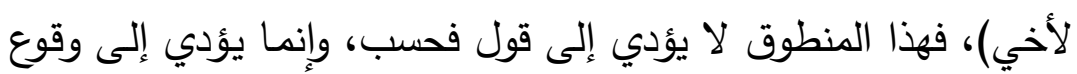
فعل هو الوصية، ويدخل فيها (التسمية، والاعتذار، والرهان، والنصـح،

$$
\begin{aligned}
& \text { والإرشاد)(r). } \\
& \text { - جهود (ســـرل) : }
\end{aligned}
$$

جاء (سيرل) ليكمل ما بدأه أوستين، فيرى (سيرل) بمشاركة (فاندرفكن) أن الفعل الإنجازي هو وحدة الاتصال الإنساني باللغة، فالفعل الإنجازي هو

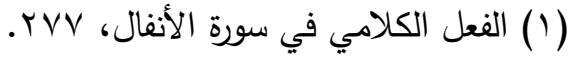
(Y) المصدر السابق، الصفحة نفسها. 
الوحدة الأولية لمعنى الجملة، وهو الوحدة الأولية للاتصال"('). وأعاد (سيرل)

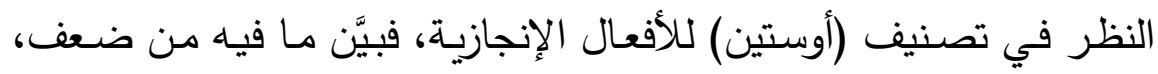
وقدم تصْنيفًا بديلاً، وقد جعله خمسة أصناف:

ا. الإخباريات (التقريريات) Assrtives: والغرض الإنجازي فيها هو نقل المتكلم واقعة ما من خلال قضية.

r. الوعـديات (الالتزاميـات) Commissives: وغرضــها الإنجـازي هـو التزام المتكلم بفعل شيء في المستقبل.

r. التوجيهـات (الأمربــات) Directives: وغرضـها الإنجـازي محاولــة المتكلم توجيه المخاطب إلى فعل شيء ما.

ع. التعبيريــات (البوحيـات) Expressives: وغرضــها الإنجـازي هــ التعبير عن الموقف النفسي.

•. الإعلانيـات (الإيقاعيـات) Declaratives: والغـرض منهـا إحداث تغيير

\section{ب) الأفضال الـكلامية في التراث اللفوي الصربي:}

لقد تنبّه العرب القدامى إلى ظاهرة الأفعال الكلامية، واعتبروها فروعًا

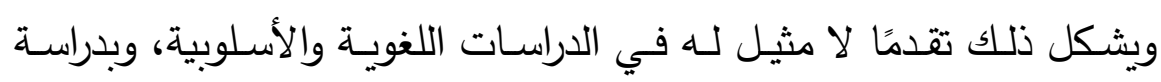
نظريـة الخبر والإنشـاء عند العرب تبين الأدوات المنهجية لدراستهم لظـاهرة (الأفعال الكلامية) التي تندرج ضمن مباحث علم المعاني، وقد كانت ظاهرة الخبر والإنشاء حقلاً مشتركًا بين علوم الفلسفة والبلاغة، والنحو، والأصول،

(1) تعديل القوة الإنجازية، محمد العبد، 10. 
وتتجلى تطبيقـاتهم في كتبهم وشـرحهم مركزين على أبعادهـا التداوليـة(')

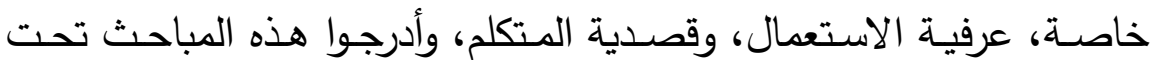
مفهوم الأغراض البلاغية للأساليب التي تقابل الأفعال الكلامية. والذي نسعى إليه من خـلال هذا البحث هو استثمار هذه النظريـة في آيات التعجيز في القرآن الكريم؛ من أجل الوقوف على الجهود التي قدمها علماء العرب في هذا المجال.

\section{ج) دلالة الإقناع من خلال الأفعال الــكلامية:}

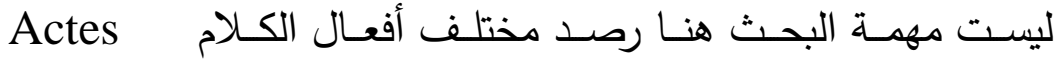
deparoles ذلك المتعلق بالرسالة الموجهة إلى مخاطبين معينين من أجل بـلاغ معتقد، أو إبلاغ معرفة، أو تبليغ وجهات نظر • ولكن البحث يركز على قوى أفعال

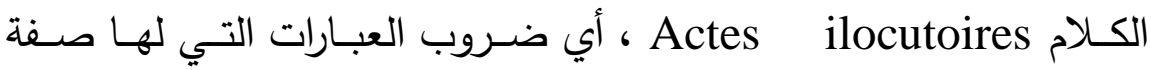
Actes المواضعة وقوتها وقيمتها، كما تتطرق إلى لوازم أفعال الكلام هذه perlocutoires إنفاذه تامًا ووقع الفراغ منه كالحمل على الاعتقاد والوصول إلى الإقناع أو

يتعين علينا إذًا أن ندرك العلاقة بين القائم بفعل القول وتحقيقه وبين آثاره ونتائجه، وبما أن الخطاب القرآني كله يمكن اعتباره حوارًا مع مختلف لفين

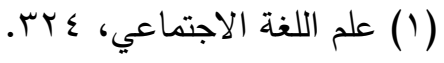

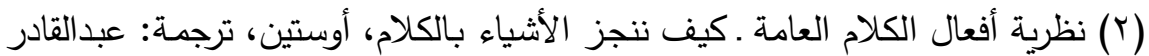

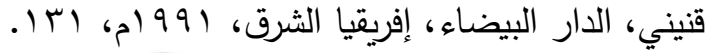




\section{الأفعال الكلامية في آيات التمجيز في القرآن الكريم دراسة تداولية}

أصناف المخاطبين، فإن النتائج والآثار تتجلى من خلال أدوارهم الواقعة أو المفترضة؛ أو من خلال ما ينتج عن أفعال الكلام ذاتها على الرغم من أن أوستين (Austin) يرى أن "نتائج حدوث الفعل ليست من صنف القول ولا

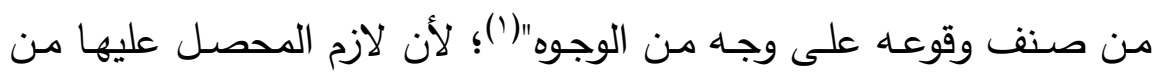
متضمنات القول التي هي في الأصل مترتبة عن تلقي فعل الكلام وليس عن الكلام ذاته بدليل أن ما يفهمهـ ويتأثر بـه متلق في سياق قد لا يحدث عند متلق آخر • هي إذن دواعي الإقناع والنفوذ الخاص بصـاحب الكلام وسريان

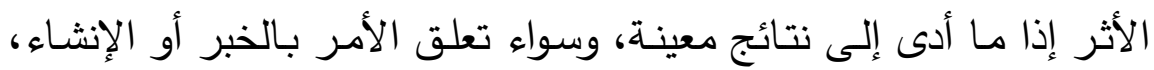
فإن قوة أفعال الكلام تكمن في الأثر الذي يتولد من القول، والذي لا يتحقق بدوره إلا بأمرين اثثين، هما:

1. بيان وجوب مطابقة الكلام لحال السامعين والمواطن التي يقال فيها. r. المعاني المستفادة من الكلام ضمنًا بمعونة القرائن(؟). ثالثًا ــ مفهوه التعجيز عند علماء اللفة (لفًّة واصطلاحًا) :

لغةت: يقول ابن فارس: "العين والجيم والزاي أصـلان صحيحان، يدل

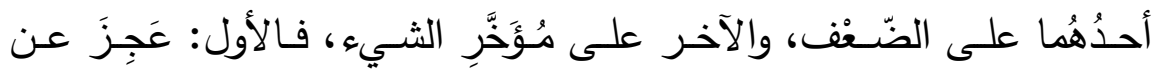

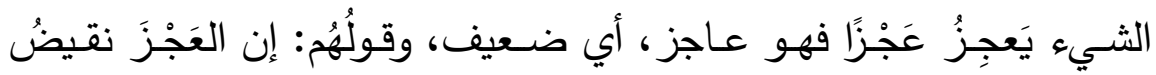

(1) (1) نظرية أفعال الكلام العامة، سبام ا.

(r) علم المعاني في البلاغة العربية، عبدالعزيز عتيق، دار النهضـة العربية، بيروت .

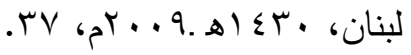




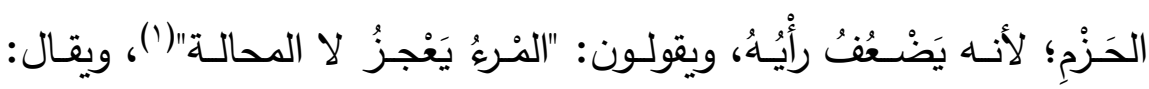

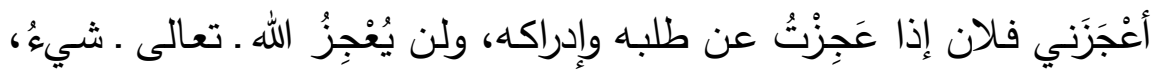

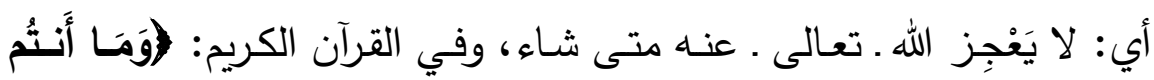

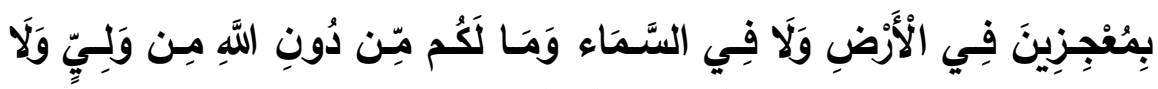

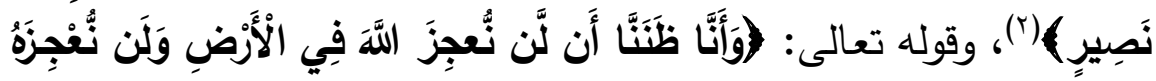

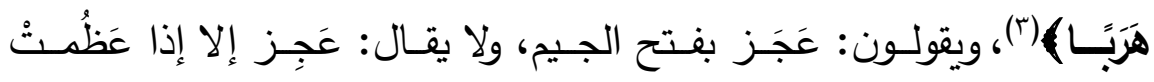

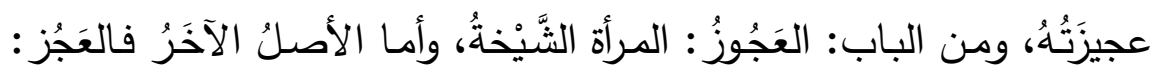

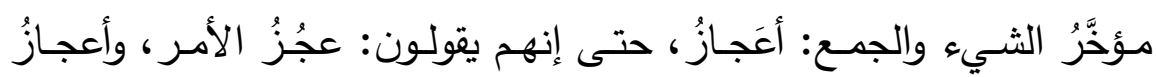

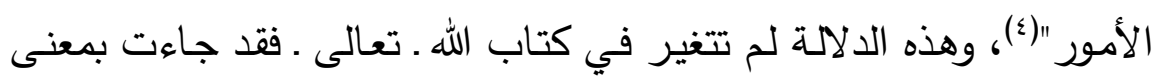

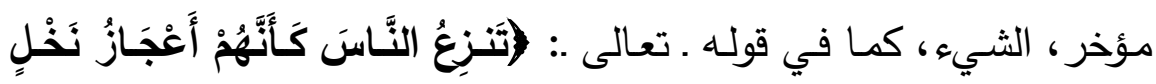

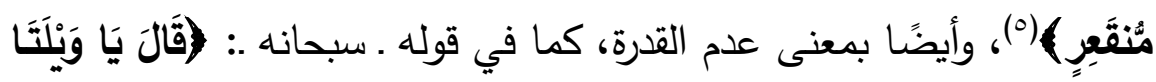

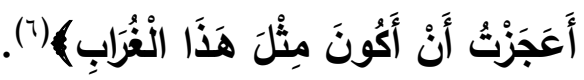

وقد يظن القارئ أن الأصلين لا صلـة بينهــا، ولكن "الصـلة بينهــا

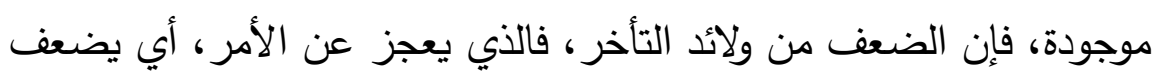
عنه، إنما هو آتيه في آخر ذلك الأمر، فلا يستقيم له الاقتدار عليه ... وكل

(1) المرء يضجر من طلب الحاجة ويتركها ولو استمر على طلبها والاحتيال لها أدركها

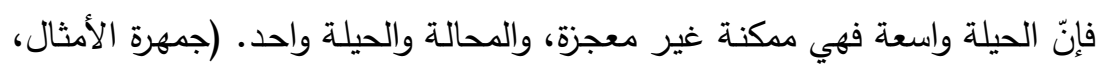

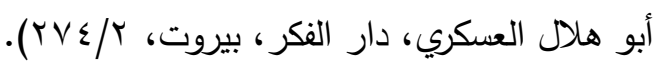

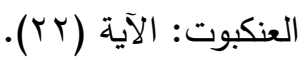

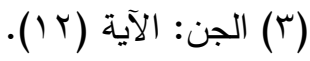

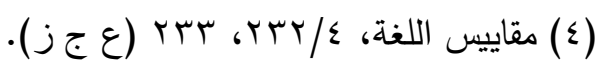

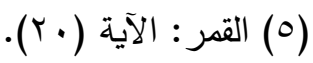

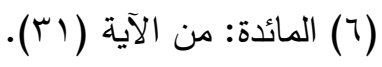




\section{الأفعال الكلامية في آيات التعجيز في القرآن الكريدر دراسة تداولية}

من تأخر عن القيام بالأمر في عجزه: ضعف عنها، وأيضًا من حاول في آخر أمره شييًا لم يقتدر عليه في أوله، فسواء أكان التأخير من شأن الفاعل

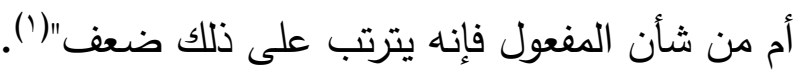
اصـطلاحًا: التعجيز محاولـة مـن أحـد طرفي الحـوار جعل الآخر لا حول له ولا قوة، وذلك حين يطلب ما هو متعذَّر، أو في حكم المستحيل، "أو هو مطالبـة المخاطب بعدل لا يقـوى عليـه؛ إظهـارًا لعجزه وضـعفه وعدم قدرته، وذلك من قبيل التحدّي"(؟). ومن الممكن أن يقال: عجز كذا مـع أنـهـ لـ يحـاول ولم يرغب في المحاولة؛ ذلك لأنه يعلم علم اليقين أن هذه المعجزة خارجة عن طوقه؛ ولذا

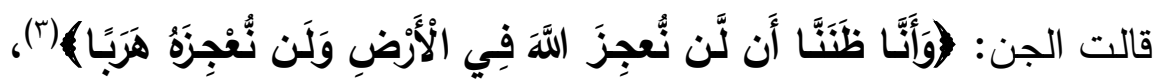
فهم لم يحاولواً: ولم يدر بخلدهم أن يحاولواً. ـ الفرق بيز وجه التمجيز ووجه التحلدي:

إن هناك فرقًا كبيرًا بين وجـه التعجيز ووجـه التحدي، ولعل أول من لفت النظر إلى هذه القضية هو ابن عطية، حين قال: "وجهه التحدي في القرآن إنما هو بنظمه وصـة معانيه وتوالي فصـاحة ألفاظه، ووجه إعجازه أن الله قد أحاط بكل شيء علمًا، وأحاط بالكلام كله علمًا يعلم بإحاطته أي

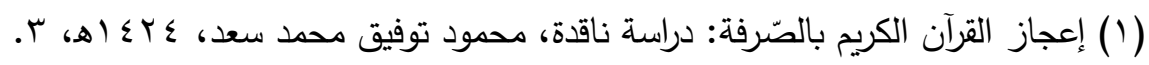

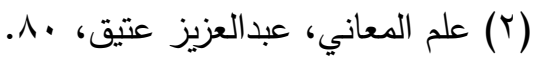
(Y) الجن: الآية (Y (Y). 
لفظة تصلح أن تلي الأولى وتبين المعنى بعد المعنى، ثم كذلك من أول

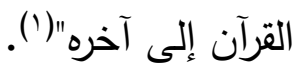
فكل شيء في القرآن هو مناط إعجاز، وأن مناط التحدي هو نظمه، أي صورة المعنى وليس المعنى نفسـ، فالمعنى القرآني نفسـه معجز، ولكنـه ليس هو مناط التحدي، والنظم القرآني معجز ومناط تحد"(؟). وبناءً على ما سبق يمكن أن يتبادر إلى ذهني مجموعة من الأسئلة حول النص القرآني الذي سأحاول التطبيق عليه، وهي: • كيف يمكن أن نضع أو نخضع النص القرآني ـ وهو نص خاص ومتميز عولج عند اللغويين ضمن مجاز القرآن وعند المتكلمين في إطار تأويل

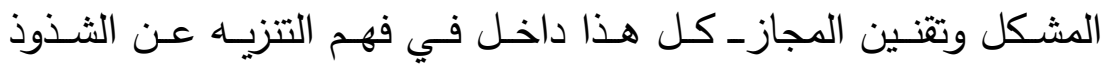
والتناقض، ثم تلاه البحث عن المزية البديعية ضمن سؤال الإعجاز وهذا العمل يلتقي مع عمل اللغوين والأسلوبين المحدثين على استكثاف ما لم يستوعبه النحو ولم تستوعبه المعايير الصرفة، وكيف نخضعه إلى دراسة لغويـة تمارس عليه سلطة التحليل كباقي النصوص الأخرى؛ لأن الكلام كثر قبله وطال؟(r). • مـا دور الأفعـال الكلامية كظـاهرة تداوليـة في توجيـه المعنى في النص القرآني؟

(1) إعجاز القرآن، محمد بن الطيب أبو بكر الباقلاني، دار المعارف، مصر، 9 ×. بع، ro/

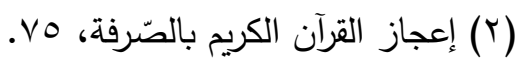

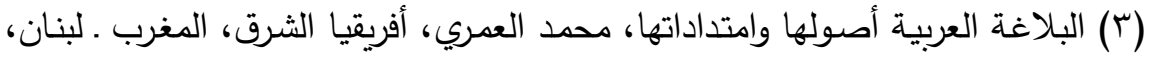

$$
\text { .r人 } 6 \text {, } r \cdot 1 \text {. }
$$




\section{الأفعال الكلامية في آيات التعجيز في القرآن الكريدردراسة تداولية}

• كيف يمكن أن نصل من خلال النص القرآني إلى اللغة، وما يردفه من

توجيه وإرشاد للمتلقين والمخاطبين (')؟ (الدراسة التداولية).

ومهمـا كانـت الانطباعـات والتصـورات بشـأن دلالـة الأفعال الكلاميـة

وأنماطها، ومميزاتها، ومرجعياتها، فإنها تن عن العائد الدلالي لكيفيات الأداء

المتميز ، والقدرة الكامنـة لمستوياتها التي تعجز بُنَي الألفـاظ المألوفـة عن وهن

تحقيقها.

(1) البلاغة العربية في ضوء الأسلوبية ونظرية السياق، محمد بركات حمدي أبو علي،

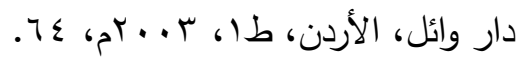




\section{اللدراسة التطبيقية}

طرق وأساليب أفمال الكلام للالالة التمجيز

توطئة :

لم يقتصر القرآن الكريم في إقامة حججه وبراهينه على طريقة واحدة، بـل تنوعـت طرقـه في عرضـها لتكـون ألـزم للحجـة، وأدعـى إلـى القبـول والملاءمة لكل عقل بشري، وحالة نفسية في كل زمان ومكان، تحقيقًا لخلود القرآن الكريخ وإعجازه إلى ما شاء الله تعالى.

وكان التعجيز والتحدي إحدى طرق إثبات هذه القضية التي سلكها

القرآن الكريم وتعددت آيات التعجيز ، وتنوعت بين عدة أسـاليب؛ لذا يهدف المبحث الآتي إلى الوقوف على الأسـاليب التي يسلكها القرآن الكريم في

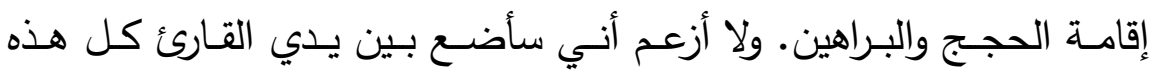
الآيـات، فهذا مـا لا طاقـة لبشـر بـه مـع كتاب لا تضضـب معانيـه، ولكننـي سأحاول جاهدة أن أتحدث عن بعض منها ما استطعت إلى ذلك سبيلا؛ لذا فهذا الجانب يتناول الأسـاليب التي طبقها القرآن الكريم في إطـار المحاور الرئيسـة، وإنمـا كانــت التسـمية (طــرق وأسـاليب)؛ لأن الطريقــة أعـم مـن الأسلوب، فالأسلوب يطبق في إطار الطريقة(')، كما أن القارئ سيجد بعض الرض آن أسـاليب حجج القرآن الكريم يرد ذكرها في أكثر من آيـة قرآنية، وليس هذا تكرار للأساليب، ولا تتاقضًا في الأسلوب الذي سلكه النص أو الحجة، وإنما جاء ذلك نتيجة طبيعية لكون كثير من حجج القرآن الكريم تحمل أكثر من

(1) التنفيذ العملي للتدريس، محمد زياد حمدان، عمان، دار التربية الحديثة، 910 ام،

$$
\text { (بتصرف يسير ) } 19 \text { / } 19
$$


أسلوب في التعجيز والتحدي، وسيلمس القارئ هذا الأمر، فالأسلوب القرآني هو: طريقته التي انفرد بها في تأليف كلامهه واختيار ألفاظه(')، ولقد تواضـع العلماء قديمًا وحديثًا على أن للقرآن الكريم أسلوبًا خاصًا بـه مغايرًا لأساليب العرب في الكتابة والخطابة والتأليف، فيتمخض هذا المعنى ويبرز في تلك المباحث التي سوف تأتي في هذا البحث.

إضافةً إلى ذلك فالقرآن الكريم باعتباره نص تأثيري فإنه لا يفصح عن

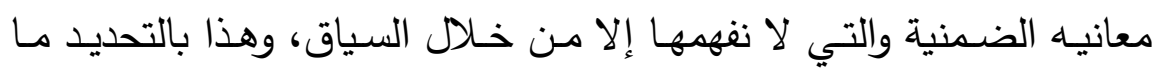
يتجسـ في نظريـة الأفعـال الكلاميـة(؟)، والتهي سـأتناولها بالدراسـة والتحليـل خـلا هذا البحث؛ للوقوف على هذه المعـاني التداوليـة التي تحويها هذه الأفعال ودور السياق في تحديدها وأثره في المعنى العام، وسأحاول توظيف هده التداولية بوصفها آلية كاشفة عن الاستعمال من جهة، ومصورة الحال والمقام من جهة أخرى، في إصابة الدلالة المرادة.

أما بالنسبة للمنهجية المعتمدة في التطبيق، فإن آيات التعجيز مجموع مركب وغير قابل للتجزيء، هذا ما دفعني إلى عدم التعامل مع أجزاء من

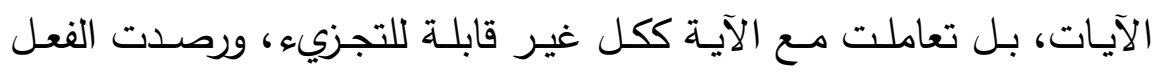
الإنجازي الأكثر تواترًا، وهو الذي مثل القوة الإنجازية في تلك الآيات. وبناءً على ذلك متُّلتِت كل آية من الآيات فعلاً كلاميًا أو جمعت بين عدد من الأفعال الإنجازية، وتستخدم الأفعال الإنجازية الأخرى في دعم هذا

(1) مناهل العرفان في علوم القرآن، محمد عبدالعظيم الزقاني، عيسى البابي الحلبي،

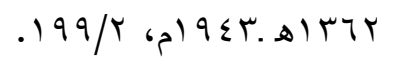

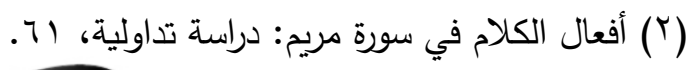


الفعـل الإنجـازي المهـيمن، أي فـي تأكيـــ نجاحسه، وتســى أوجــه إنجـاز

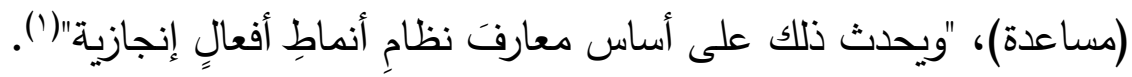
كما يجب أن ينظر إلى الإنجاز بوصفه جانبًا قصديًا لفعل كلامي في

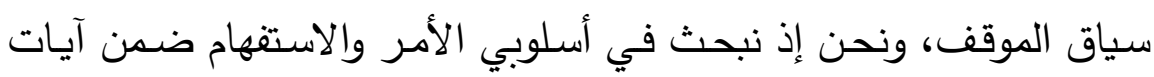

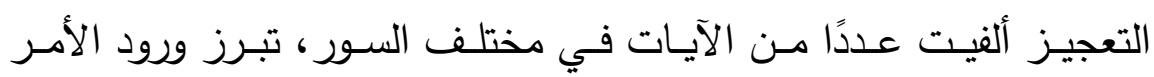

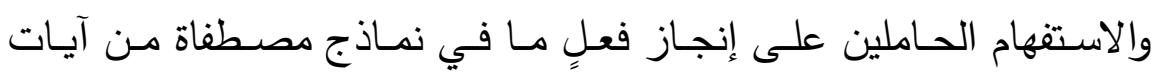
التعجيز في القرآن الكريم على النحو التالي:

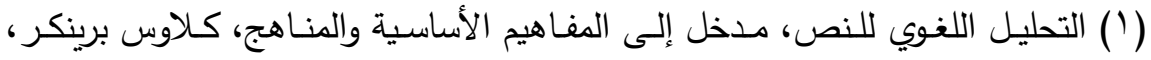

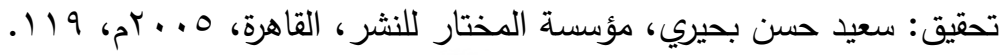




\section{المبحث الأول}

\section{الأثر التداولي لأفضال الكلاه في أسلوب الأمر}

توطئة:

يُعـد أسلوب الأمـر فـي البلاغــة العربيـة واحدًا مـن الأفعـال اللغويــة الإنجازية المنشئة للأفعال في واقع الناس، وهو أسلوب أو فعل قولي مباشر ،

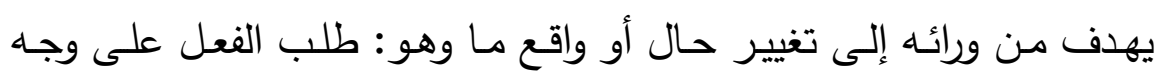

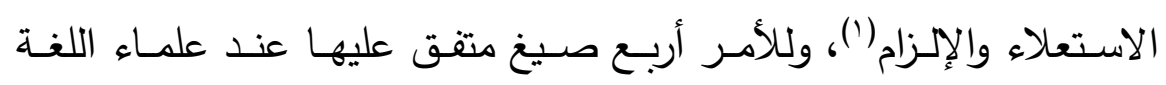

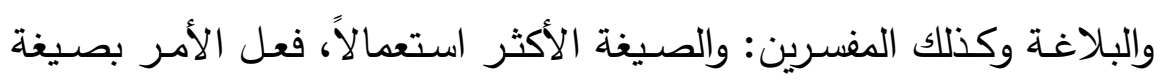
(افْعَل)

يأتي فعل الأمـر ضـمن أفعال التتفيذ والتوجيه، ويكون إمـا بغرضـهـ

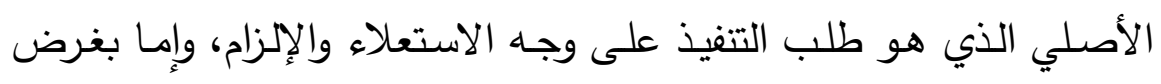

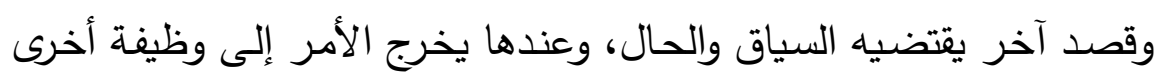

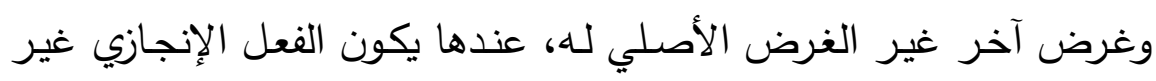
مباشر، والأفعال الإنجازية كلها أفعال قصدية تهدف إلى التأثير والتغيير.

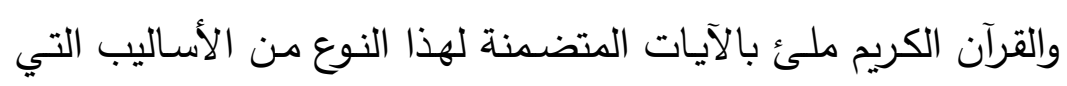

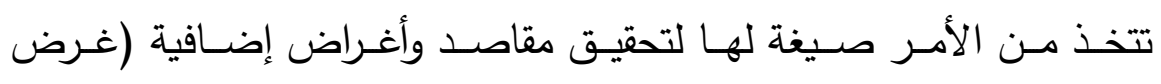

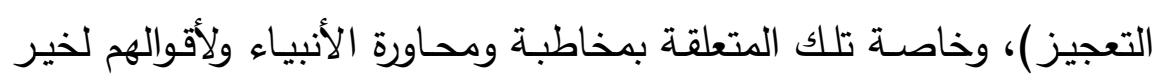

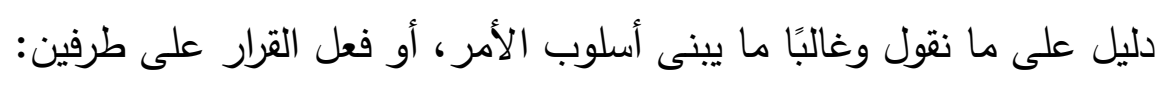
الأول: ويمثله الطرف الأدنى وهم الكفار.

(1) (1) علم المعاني، عبدالعزيز عتيق، 
والثاني: ويمثله الله ـ عز وجل ـ والأنبياء (')؛ ولهذا كان لفعل الأمـر أهمية بالغة في تحريك النفوس وردعها وزجرها، وبيان ذلك كالتالي:

\section{أولاً ـتمجيز من الله ـ عزوجل ــللكافرين:}

\section{توطئة:}

عرض القرآن الكريم مسألة الثك في القرآن الكريم في غير آية وغير

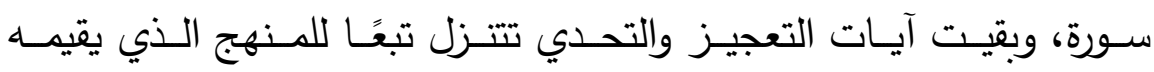

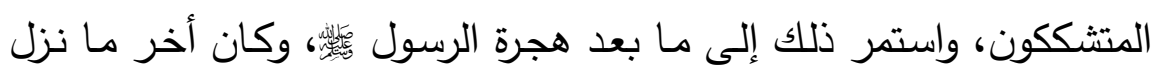

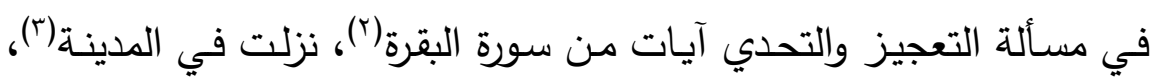
وتمثل آيات التعجيز خطابين في القرآن الكريم:

أحدهما: إقامة التحدي فعليًا، وهو ما يساوي طلبًا حقيقيًا للإتيان بقرآن آخر • والآخر: إقامة التعجيز فعليًا، وهو ما يساوي نفيًا حقيقيًا للإتيان بقول آخر، وخطاب الله تعـالى للكفـار كان مباشرًا وغير مباشرِ بوسـاطة رسوله

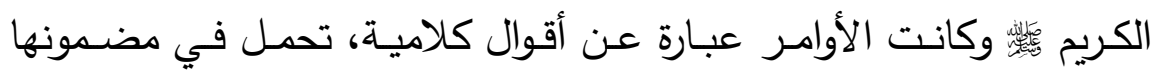
مقاصـد تنفيذيـة وتوجيهيـة، وتحمل أوامر تدعو إلى التكليف بأعمـال تعود بالفائدة، ومن أمثلة ما جاء في هذا الغرض لآيات التعجيز ما يأتي:

(1) لغـة الخطاب القرآني في بني إسرائيل: دراسـة أسلوبية دلالية، (رسالة ماجستير)،

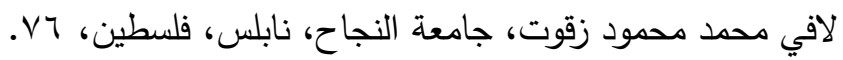

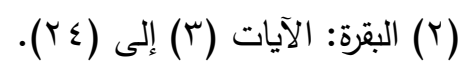

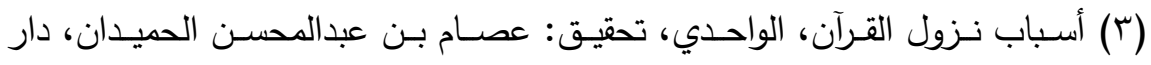

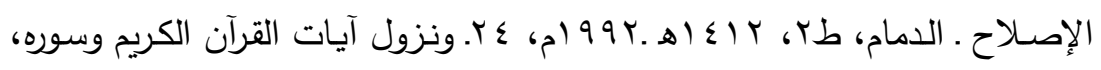

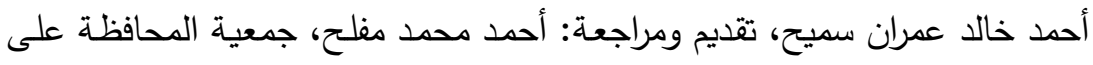

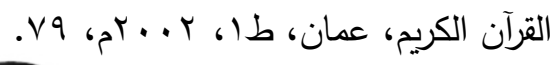




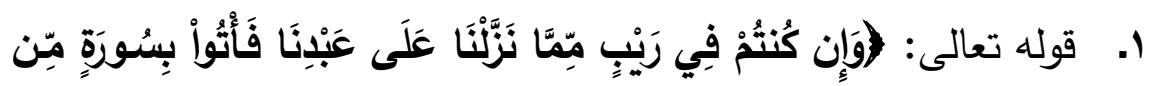

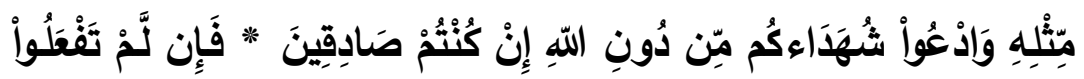

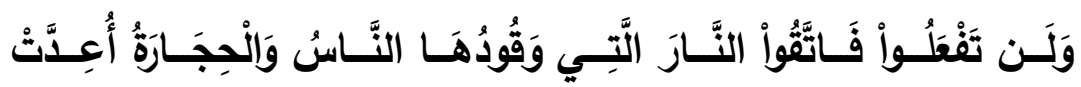

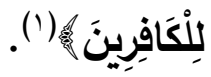

المعنى اللفوي:

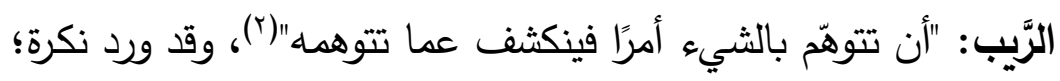

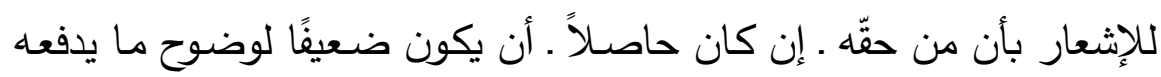
ووجود ما يزيله"(").

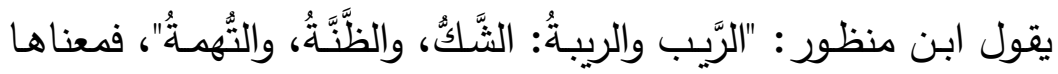

$$
\text { يدور حول الثك المصاحب للتهمة(؛). }
$$

نزلنا: "إيثار التتزيل المنبئ عن التدريج على مطلق الإنزال لتذكير منشأ ارتيابهم وبناءٍ التحدي عليه إرخاءً للعنان وتوسيعًا للميدان، فإنهم كانواً

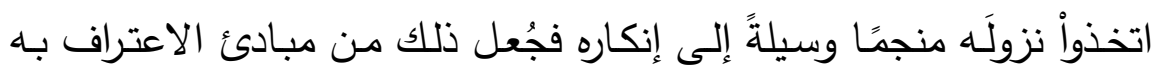
كأنه قيل: إن ارتبتم في شأن ما نزلناه على مهل وتدرجٍ فهاتواً أنتم مثلَ نَوبـةٍ

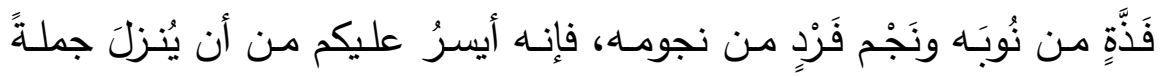

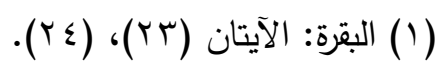

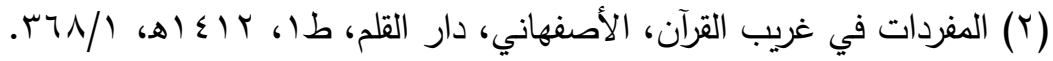

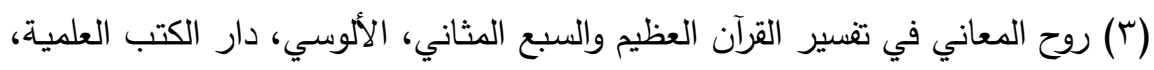

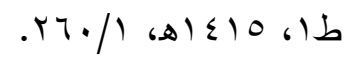

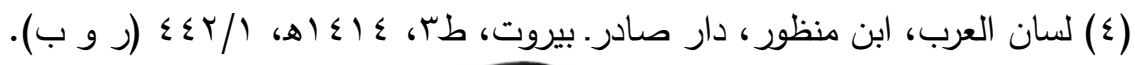


واحدة، ويُتحذّى بالكلّ، وهذا كمـا ترى غايـةُ مـا يكون في التبكيت وإزالـة

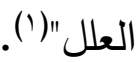

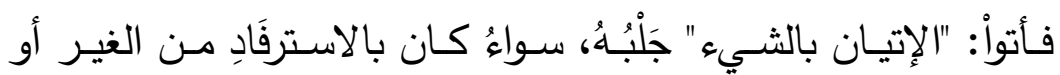

بالاختراع من الجالب، وهذا توسعةُ عليهم في التحدِّي"(().

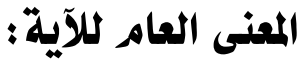

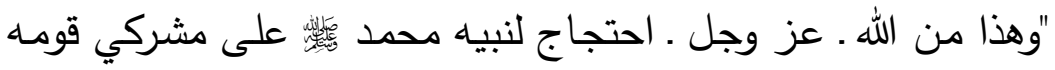

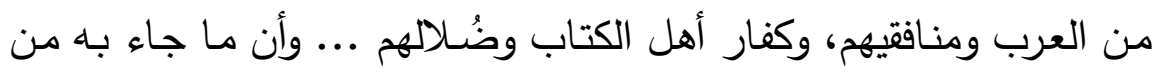

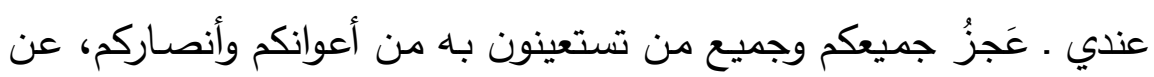

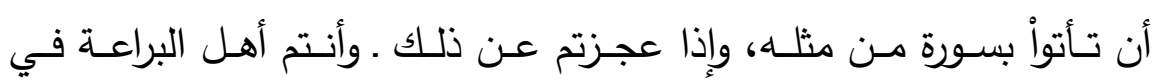

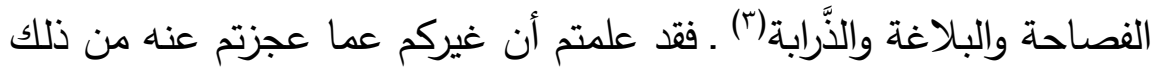

أعجزٌ "(i)

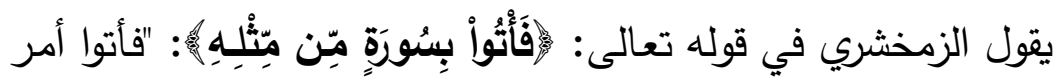

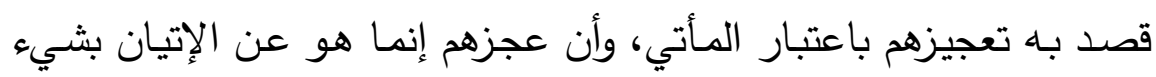

( (1) إرشاد العقل السليم إلى مزايا الكتاب الكريم، أبو السعود، دار إحياء التراث العببي،

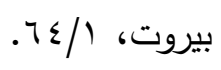

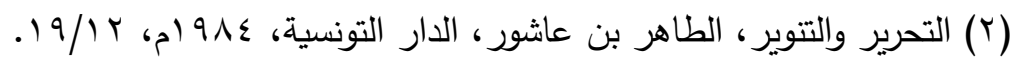

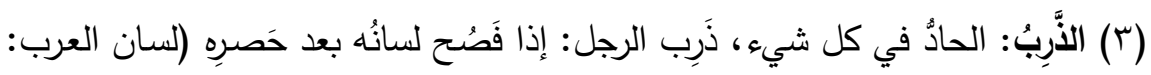

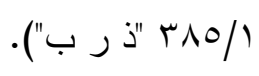

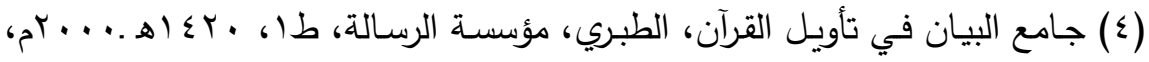

$$
\text { . TrL/ }
$$




\section{الأفعال الكلامية في آيات التعجيز في القرآن الكريدر دراسة تداولية}

منه على قياس معناه: فأتواً بسورة مما هو على صفته في البيان والغريب

وعلو الطبقة وحسن النظل" (').

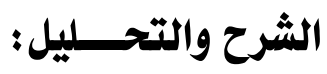

"ويبدأ هذا التحدي بلفته لها قيمتها في هذا المجال ... يصف الرسول

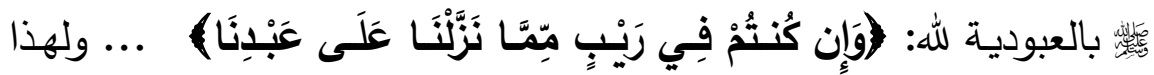
الوصف في هذا الموضع دلالات متنوعة متكاملة:

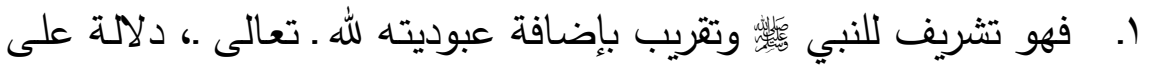
أن مقام العبودية لله هو أسمى مقام يدعى إليه بشر ويدعى به كذلك.

r. أما التحدي فمنظور فيه إلى مطلع السورة ... وهذا التحدي ظل قائمًا

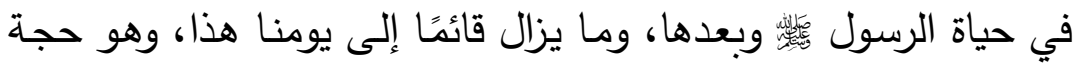

لا سبيل إلى المماحكة فيها"(؟).

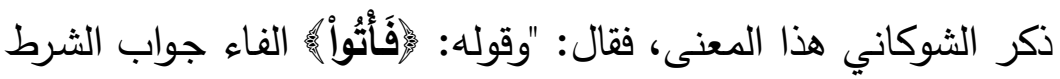

وهو أمر معناه التعجيز ... فتحداهم بأن يأتواً بسورة من سوره.... (وَادْعُواْ)،

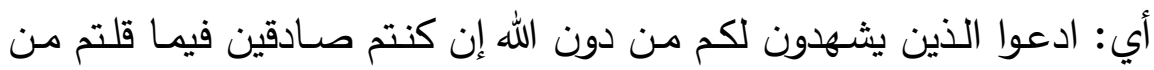

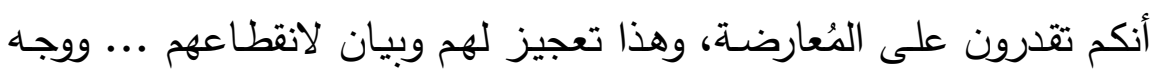
الإعجاز في القرآن الكريم هو كونه في الرتبة العليّة من البلاغة الخارجة عن

(1) الكثاف عن حقائق غوامض التززيل، الزمخشري، دار الكتاب العبب، بيروت، ط؟،

$$
\text { rTV/r (ه) } \varepsilon \cdot V
$$

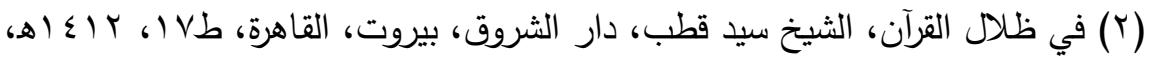
.$\leqslant \wedge / 1$ 
طَوْقِ البشر"(")، فهو فوق قدرتهم وإمكاناتهم، أي: "ادعوا الذين يشهدون لكم من دون الله إن كنتم صـادقين في قولكم من أنكم قادرين على المعارضــة،

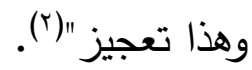

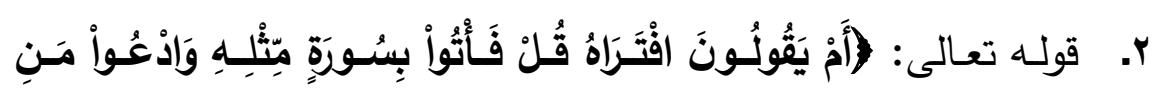

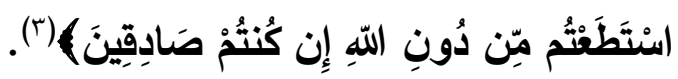

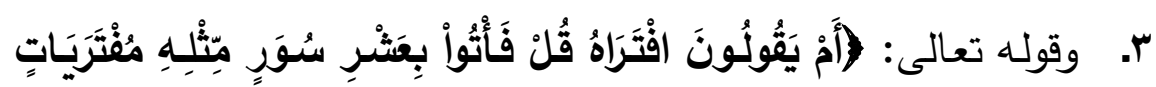

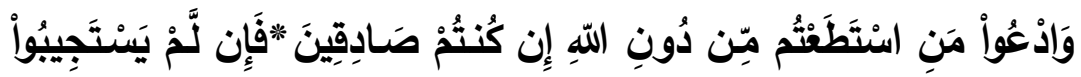

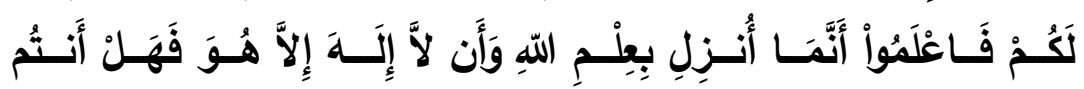

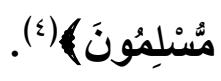

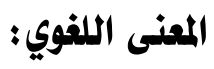
الافتـراء : مـن الفـري وهـو "قطـع الجلـد للخـرز والإصــلاح، والإفـراء للإفساد والافتراء فيهما، وفي الإفساد أكثر ؛ وكذلك استعمل في القرآن في

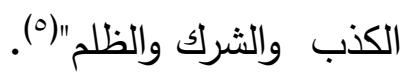
المعنى العام للآيات:

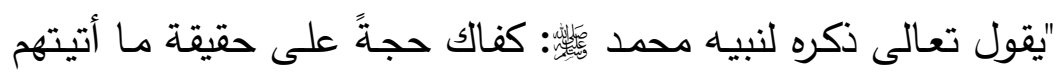
بـه، ودلالة على صحة نبوتك هذا القرآن، من سائر الآيات غيره، إذ كانت

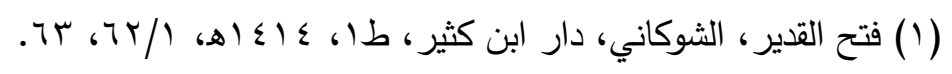

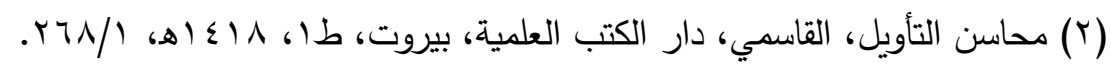

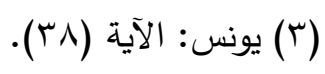

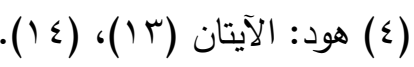

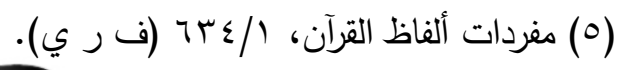




\section{الأفعال الكلامية في آيات التعجيز في القرآن الكريدردراسة تداولية}

الآيات، إنما تكون لمن أُعَطيها دلالة على صدقه، لعجز جميع الخلق عن أن يأتواُ بمثلها، وهذا القرآن، جميع الخلق عَجَزَة عن أن يأتواً بمثله..."(').

\section{الشرح والتحـــليل : - الش}

أول مـا يلفت النظر- هنا ـ هو تصدُّر الآيتين الكريمتين بـ(أم) وهي هي للإضراب الانتقالي من النفي إلى الاستفهام الإنكاري التعجبي. والغرض منهـ إبطال دعواهم أن يكون هذا القرآن مفترَّى من دون الله . جلا وعلا .. و"أم" هذه هي التي تتقدر عند النحاة بـ(همزة الإنكار) و(بل)، وعليه

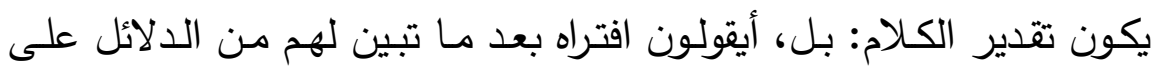
صدقه وبراءته من الافتراء؟، وقيل: إنكار لقولهم واستبعاد، "فجاء هذا الكلام على كلام العرب قد علم تبارك وتعالى وذلك من قولهم، ولكن هذا على كلام

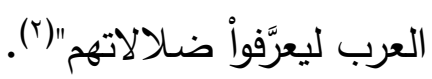




\section{ـ الفعل الإنجازي المتضمن في القول(') - (1)}

قوة المنطوق الإنجازية جزء مكمل لمعناه؛ ولذلك استخدم القرآن الكريم

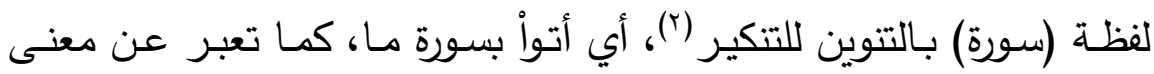
التبكيت والتحميل لهم، وكذلك يدعم الإنجاز باستخدام لفظ (من) التبعيضية

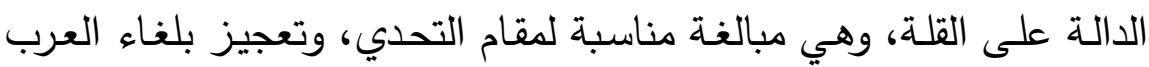

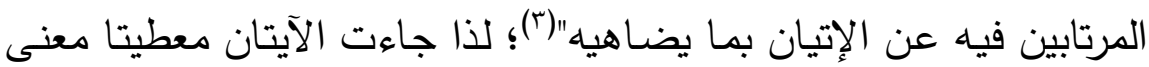

( () لكل فعل كلامي . كما حدد أوستين . لابد أن يتضمن داخله ثلاثة أفعال جزئية، وهي:

• "ا. الفعل اللفظي (الفعل اللغوي أو فعل القول): وهو يتألف من أصوات لغوية

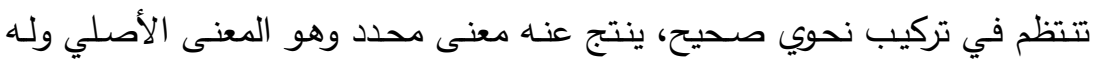

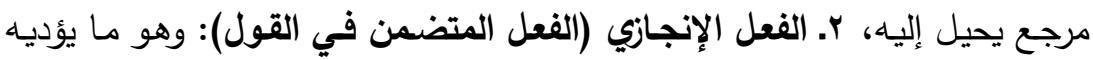

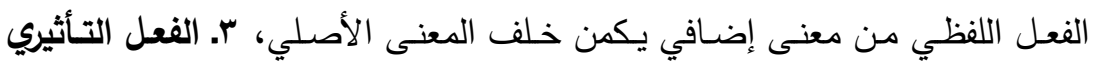
(الفعل الناتج عن القول): ويقصد به الأثر الذي يحدثه الفعل الإنجازي في السامع".

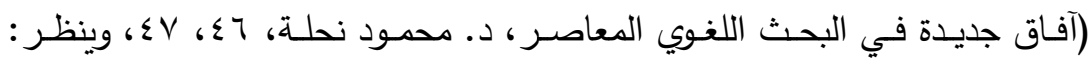

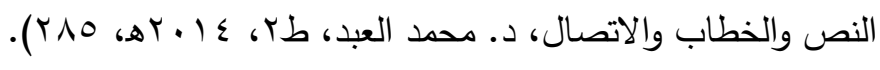

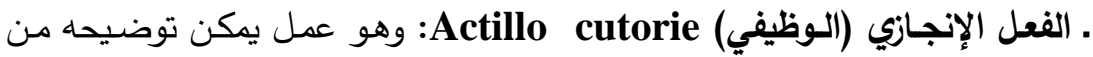

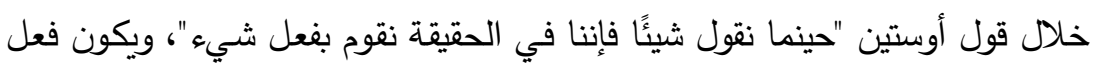

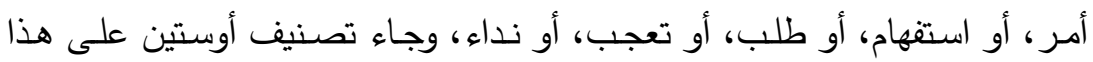

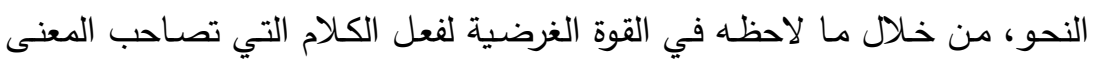
الصريح والحرفي الذي ينجزه هذا الفعل. (تجليات مفاهيم التداولية في التراث العربي، التربي،

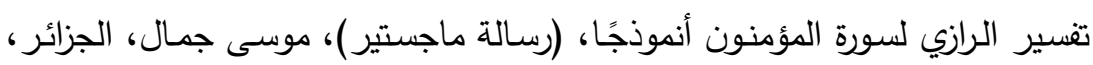

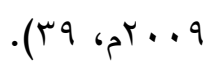

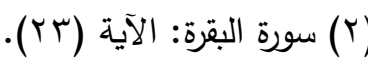
(T) الأفعال الكلامية في القرآن الكريم (سورة البقرة)، .11. 


\section{الأفعال الكلامية في آيات التعجيز في القرآن الكريدر دراسة تداولية}

التعجيز بغرض إظهار عجز مـن يـرى أن في وسـعه أن يفعل أمـرًا ليس بمقدوره أن يفعله.

كما أن العجز كفعل تأثيري حاصل لا محالة، فقد خاطبهح مجتمعين، وأردف تحديهح حينما طلب منهم دعوة شهدائهم لإعانتهم أو قضاء حاجاتهم، وهو ما يسميه (أوستن) "بمصاحبة المنطوق الخاصـة بالمتكلم"('). فالتداولية في الفعل الكلامي ملحوظة في الفعل الإنشائي وهو الأمر (فادعواً) المراد بـه التعجيز وهو معنى خفي في غير ملفوظ.

ثم احتج · سبحانه ـ على صحة القرآن، وأنه ليس بمنقول، فقال تعالى:

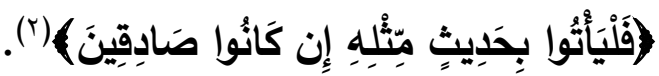

والفـاء هنـا للتعقيب، أي: إذا كان القرآن منقولاً كمـا يـدعون، فيجب عليهح بأن يأتواُ بحديث مثله، إن كانوا صادقين.

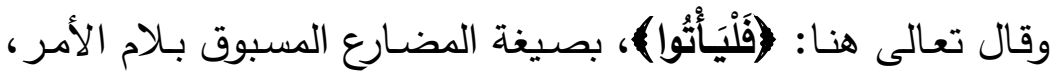

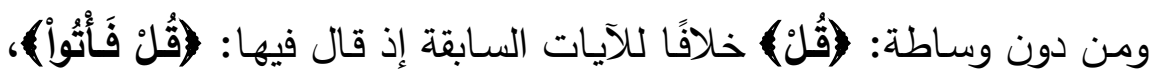
والسر في ذلك:

أولاً: أن التحدي بقوله تعالى: (فَلَيَاتْتُوا) تحدِّ غير مباشر يعمٌ كل من نسب إلى النبي

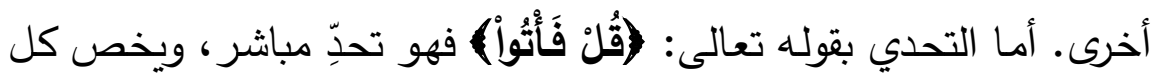

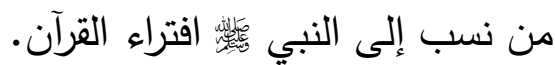

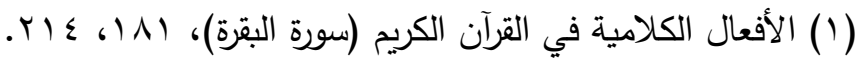

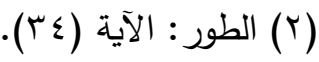


ثانيًا: أن التعبير بصيغة المضارع المسبوق بـلام الأمر (فَلََأْتُوا) يفيد

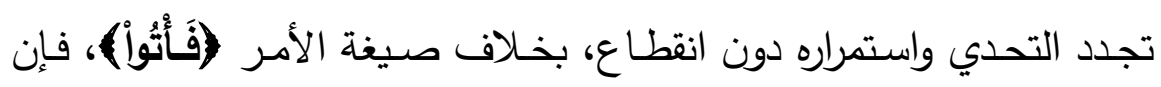

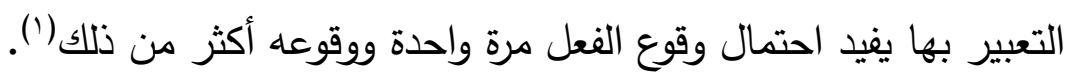
وبالرجوع إلى بعض كتب التفسير ثبت أن "الأمر في قولـه تعالى:

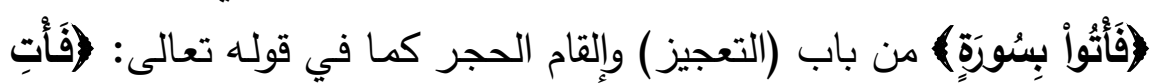

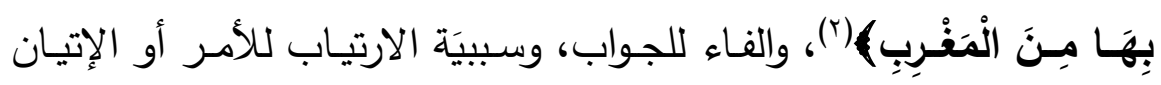
بالمأموريه، لما أشير إليه من أنه عبارة عن جزمهم المذكور فإنه سبب للأول

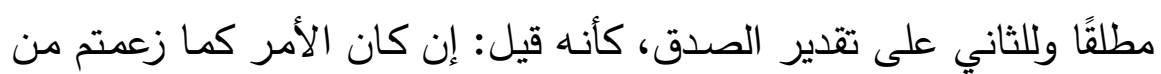
كونه كلام البشر فأتواُ بمثله"(؟).

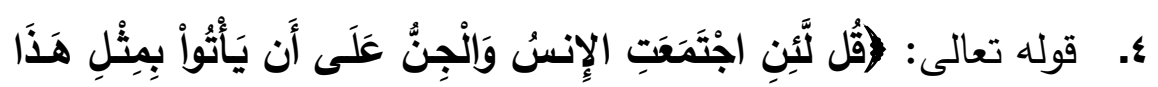

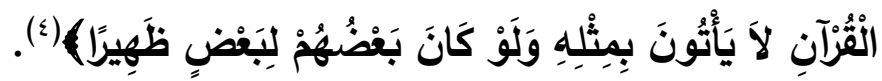

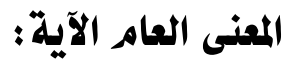

"قل يا محمد للذين قالوا لك: إنا نأتي بمثل هذا القرآن: لئن اجتمعت

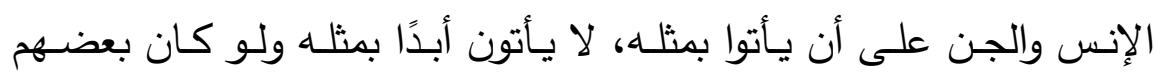

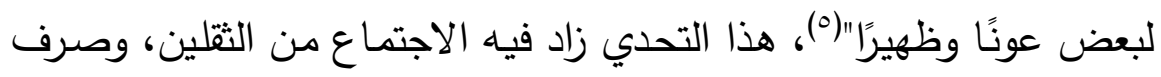
الهمم للتظاهر والتعاون والتطافر، فقال مؤكدًا باللام الموطئة للقسم لادعائهم

(1) الإعجاز اللغوي والبياني في القرآن الكريم، جمع وإعداد: علي بن نايف الثحود، . $\{9$

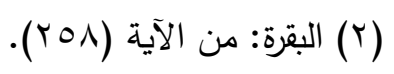

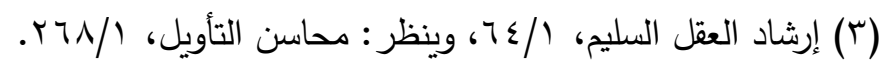

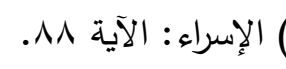

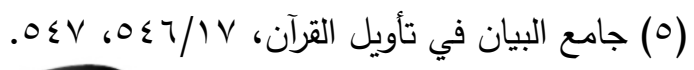




\section{الأفعال الكلامية في آيات التعجيز في القرآن الكريدر دراسة تداولية}

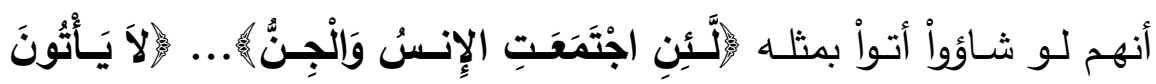

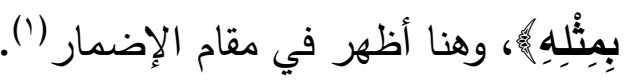

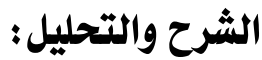

افتتحت الآيـة بفعل الأمر (قل)، وأغلب الآيـات القرآنية التي تفتتح

بفعل الأمر (قُل) يراد بها التتبيه أو الاهتمام بما يقال، أمسا في هذه الآيـة المباركة، فإن فعل الأمر جاء للتنويه والاهتمام بمقام القرآن، "وافتتاحه بـ(قُلن)

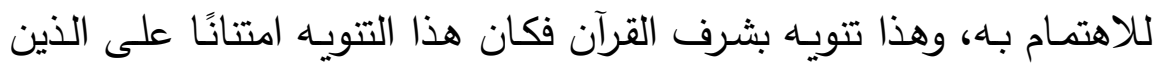

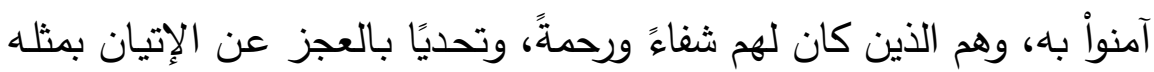

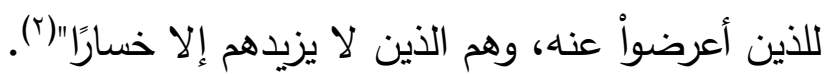
قال الخطابي: "إن قومًا ذهبواً إلى أن العلـة في إعجازه ـ أي القرآن

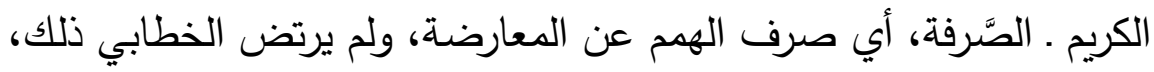

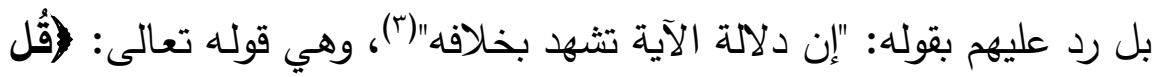

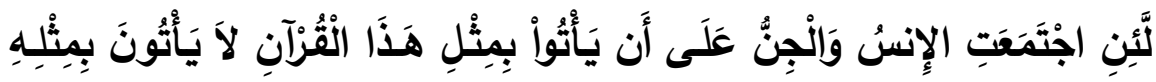

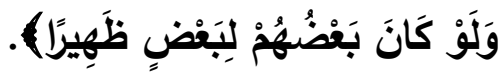

كما قرر السيوطي بطلان المذهب، فقال: "فإنه يدل على عجزهم مـ

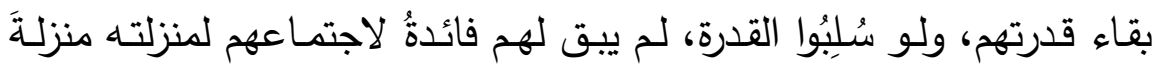

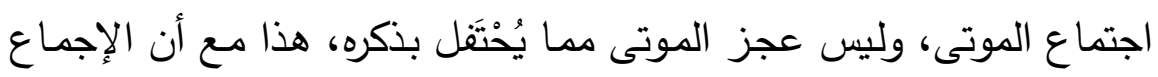

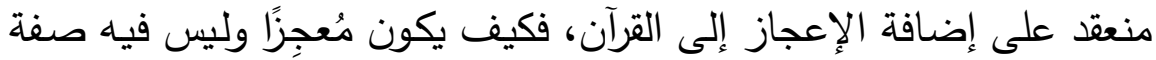

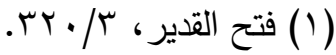

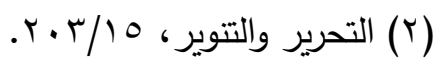

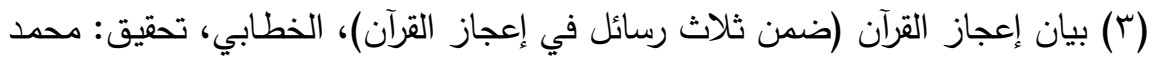

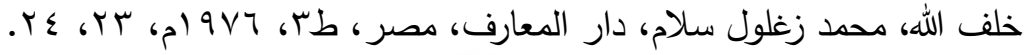


إعجاز ؟ بل المعجز هو الله تعالى، حيثُ سَلَبَهم القدرةَ على الإتيان بمثله،

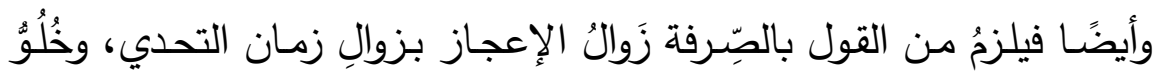

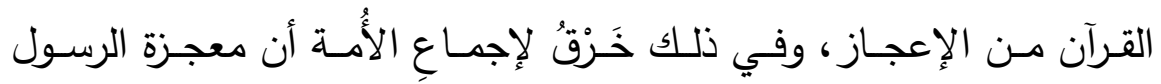
العظمى باقية، ولا معجزة لله باقية سوى القرآن"(').

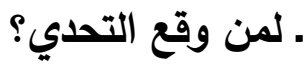

قال الإمـام الزركثي:"التحدي إنما وقع للإنس دون الجن؛ لأن الجن ليسواُ من أهل اللسان العربي الذي جاء القرآن على أساليبه، وإنما ذُكِرُواْ في لإني

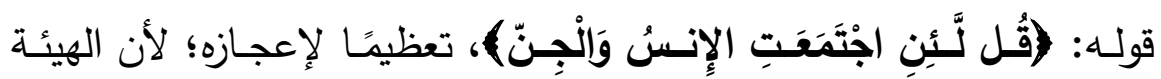

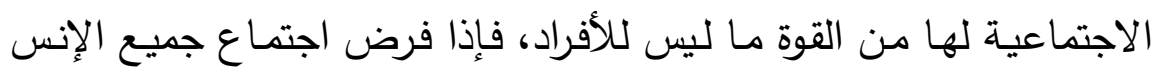

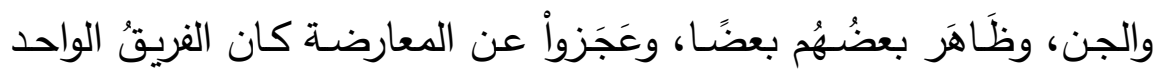

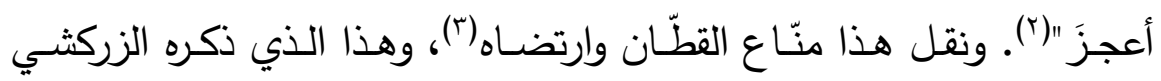

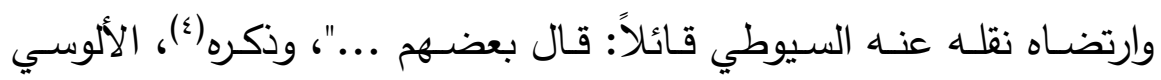

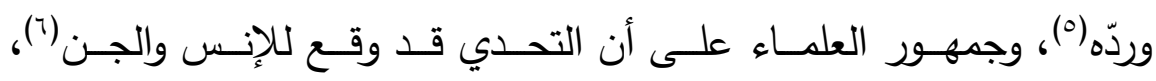

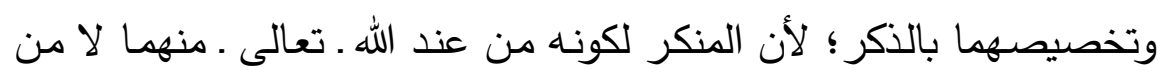

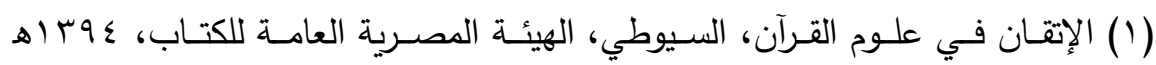

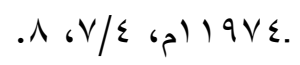

(Y) البرهان في علوم القرآن، الزركثي، تحقيق: محمد أبو الفضل إبراهيم، دار إحياء

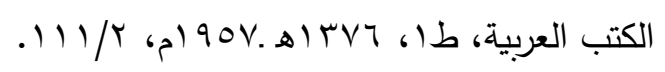

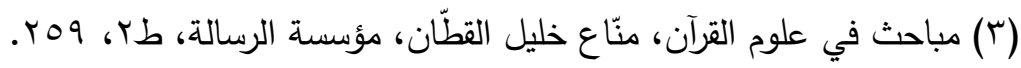

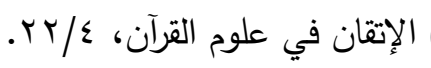

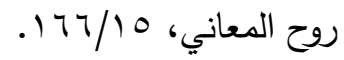

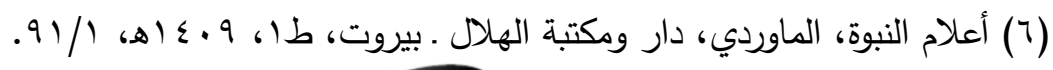




\section{الأفعال الكلامية في آيات التعجيز في القرآن الكريدر دراسة تداولية}

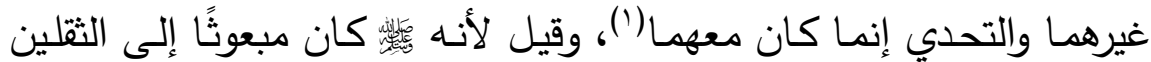

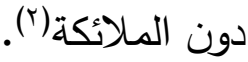

ـ الفعل الإنجازي المتضمن في القول:

أرى أن القوة الإنجازيـة للفعل الكلامي (وهو الفعل الذي يتركب من

ثلاثة أفعال سبق ذكرها في هامش (r)، الصفحة اب) في هذه الآيـة هو الإخبار عن المعجزة التي نزل بها الرسول الكريم أعجز أهل الفصاحة والبلاغة، أما القوة الإنجازية الملتزمة للفعل الكلامي في لهي هذه الآية، فهي التحدي وتعجيز المنكرين لهذا القرآن بالأمر (قُلن) وتتمثل قوتـهـ الإنجازيـة المباشـرة فـي طلب الأداء، وهـو أمـر الله تعـالى للكـافرين والمشركين أن يأتواُ بمثل القرآن الكريم، هذا هو المعنى الحرفي المباشر، أما القـوة الإنجازيـة غيـر المباشـرة أو المعنى الضــنـي فهـو التعجيز ، والفعـل التأثيري هاهنا يتمثل في كثف كذبهم وزيغهم وتوبيخهم وإقامة الحجة عليهح للعـودة إلى الحقى، وذكـر الجـن في الآيـة الكريمـة هـو زيـادة ومبالغـة في تعجيزهم؛ "لأنهم إذا عجزواً عن الإتيان بمثله ومعهم الجن القادرون على ونى

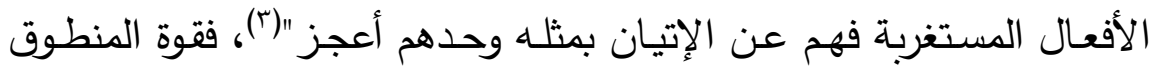
الإنجازية جزء مكمل لمعناه.

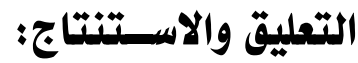

بناءً على ما سبق من آيات يتضح الآتي:

$$
\begin{aligned}
& \text { (1) روح المعاني، 101/1. }
\end{aligned}
$$

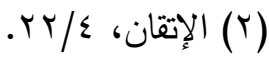

$$
\begin{aligned}
& \text { روح المعاني، 101/ 1. }
\end{aligned}
$$


1. تتعالق هذه الآيات السابقة في إقامة وظيفة عميقة تثير إلى علاقة بين الله تعـالى، والخطـاب الإلهي، تتمثل هذه الوظيفـة في بنيات متكافئة دلاليًا:

(مِّمَّا نَزَّنَنَا عَلَى عَبْدِنَا) (1): هذه البنية تمثل وظيفة التنزيل من أعلى إلى أدنى، وتؤسس لواحدة من أهم القضايا في الخطاب القرآني، وهي مسألة توحيد الله، في مقابل هذه الوظيفة توجد وظيفة مهمة ذات علاقة بتكوين وظيفة التوحيد، وهي وظيفة التعدد في الألهة، قال ابن كثير : "الأن التحدي عامُّ لهم كُلُّهم، مع أنهم أفصح الأمّم، وقد تحدّاهم بهذا في

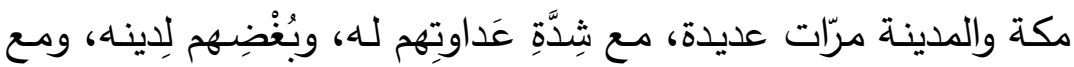

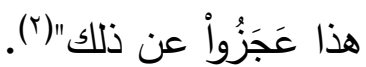

r. تتعالق هذه الآيات من وجهتين في التحليل اللساني؛ من وجهة البنية أو الثكل، ومـن وجهـة المعنى الذي يتمثل في وحدة الموضـوع، فآيـات التعجيز والتحدي السابقة لم تخرج عن بنية الموضوع في إثبات صدق الخطاب الإلهي، وكان ذلك ممـا يصـح وقوعـه في آيـة واحدة، إلا أن سرد الآليات يقدم فكرة التعجيز والتحدي بتكوينات مختلفة، يجري ذلك في مغزى يظهر عجزهم، ويظهر صدق نزول الوحي من الله. سبحانه

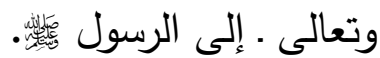

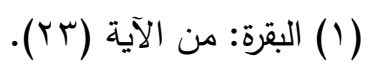

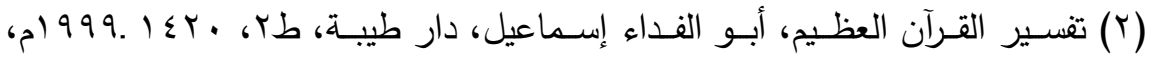




\section{الأفعال الكلامية في آيات التقجيز في القرآن الكريدر دراسة تداولية}

r. التكرار اللفظي والـدلالي ('): حيث استعمل القرآن الكريم صـيغًا بديلـة متكافئة وظيفيا(؟)، من مثل: عشر سور ، سورة، من مثله، كما نلحظ

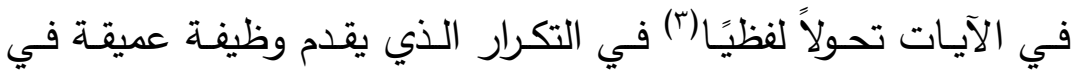
التحليل الدلالي، فعشر سور لا يمثل سورة، وإن كان الأمر في تركيب واحد، وفي مقصد واحد، إلا أن بناء المعنى يتصعد تبعًا لعلاقة المقصد باللفظ المستعمل، فالتعليق الإعجازي مستمر في إقامـة حقيقـة مطلقـة حول الخطـاب الإلهـي في أصسر السور القرآنيـة حجمًا، لكن طلب الإتيان بسورة يختلف عن طلب الإتيان بعشر سور، حيث ينحوا السرد القرآني إلى تمكين البنيـة الإعجازيـة بإقامـة التحدي بمستويات دلاليـة غير متوقعة(๕). ع. الإحالـة الدلاليـة(ْ): تتمثل في استعمال تكوينـات دلاليـة متماثلـة، مـن ذلك:

( (1) لسانيات النص (مدخل إلى انسجام الخطاب)، محمد خطابي، ـ ب، وينظر أيضًا:

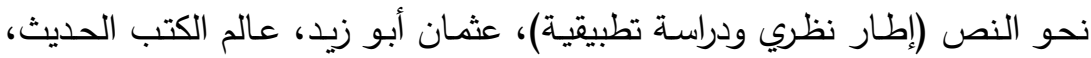

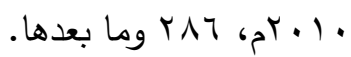

(Y) مدخل إلى علم النص ـ مشكلات بناء النص ـ ز زتسيسلاف واورزنياك، ترجمة: سعيد

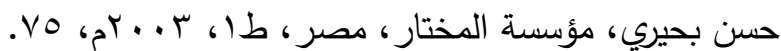
(r) تكرار وظيفيًا، حيث يبقى المعنى دون اللفظ. (؛) البلاغة والأسلوبية نحو نموذج سيمائي لتحليل النص، هنريش بليث، ترجمة وتحقيق:

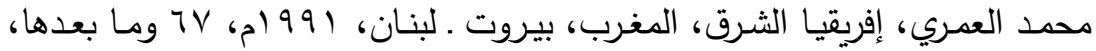

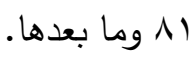

(0) الإحالــة فـي علـم الدلالــة هـي: العلاقـة بين الأسماء والأشياء، أو بـين الضـمائر

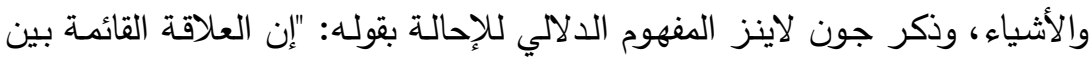

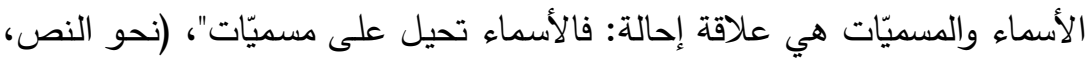

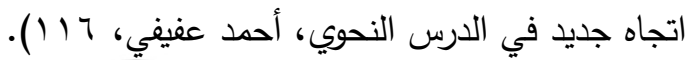




$$
\text { أ ) اللفظ (افتراه). }
$$

ب) اللفظ المعقود عليه التحدي (سورة)، (عشر سور)، (حديث مثله)، وهذه تكوينات وظيفية في الإعجاز والتحدي تمثل عمقًا في المنحنى الدلالي؛ من جهة أن خطاب الإعجاز لم يستقر على تمثيل واحد في طلب الإتيان، فكان مرة بسورة، ومرة بعشر سور ، ومرة بمثل القرآن.

\section{ـ الحروف المقطعة في فواتح السور:}

من روائع البيان القرآني المعجز (فواتح السور)، حيث كان افتتاح كل سورة قرآنيـة افتتاحًا مناسبًا لها، من حيث موضـوعها وكلماتها، وحروفها، محققًا الإعجاز البياني فيها المؤدي إلى التعجيز •

قـال الإمـام السيوطي عن روعـة فواتح السور نـاقلاً عن أهل البيان

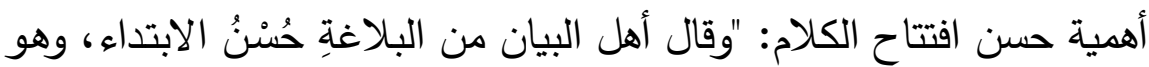

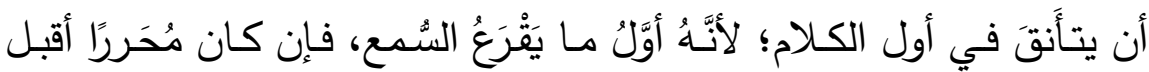
السـامعُ على الكـلام ووعـاهُ، وإلا أعـرضَ عنـه، ولـو كـان الباقي في نهايـةِ

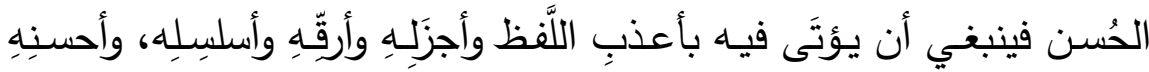

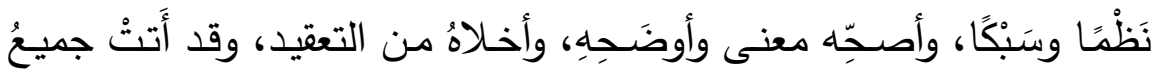

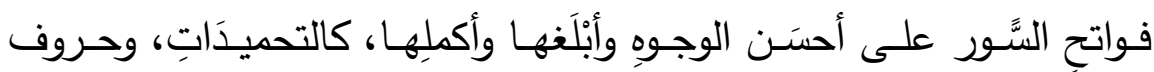
الهجاء، والنداءِ، وغير ذلك" (1).

ومن التفصيل لهذه الفكرة الإثارة إلى مسألتين، هما: • الأولى: صور افتتاح السور . 


\section{الأفعال الكلامية في آيات التمجيز في القرآن الكريم دراسة تداولية}

$$
\text { ـ الثانية: الحروف المقطعة في فواتح السور . }
$$

وقد تكلم العلمـاء عن هـاتين المسـألتين، وبينواُ روعـة البيان القرآنـي

فيها، منهم: الإمام الزركثي(')، والإمام السيوطي (r)، ونوجزه فيما يأتي:

\section{أولاء_صور افتتاح السور:}

افتتاح السور القرآنيـة افتتاح رائع، يحقق الإعجاز البياني القرآني، وسور القرآن مئـة وأربـع عشرة سورة، وصسور افتتاحها محصسورة في عشر صور ، منها: الحروف المقطعة: في تسع وعشرين سورة.

\section{ثانيًا ــ الحروف المقطعة في فواتح السور:}

افتتاح بعض السور بالحروف المقطعة مظهر من مظاهر الإعجاز

البياني في القرآن الكريم، ويطلق عليها (الحروف النورانيـة)، وقد اختلف العلماء والمفسرين والبيانيون في المراد بهذه الأحرف، ولهم في هذا أقوال

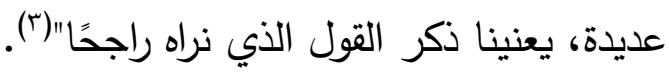

القـول الـراجح هـو: أن الله تحدى الكافرين، وطـالبهج بالإتيـان بمثل القـرآن، فـافتتح بعض السـور بهـذه الأحـرف المقطعـة مـن بـاب التحـدي والتعجيز؛ لأنه يخبرهم بذلك أن القرآن مكون من هذه الحروف الهجائية، وهم عرب يتكلمون لغـة عربيـة مكونـة من هذه الأحرف الهجائيـة نفسها، فهذا القرآن في بيانه لـ يخرج عن حروف وكـلام لغتهم العربية، فإذا كان هذا القرآن كلام بشر فإنهم يستطيعون الإتيان بمثله، وإذا عجزواً عن معارضته لئه

$$
\begin{aligned}
& \text { (1) البرهان في علوم القرآن، / / آ أ. }
\end{aligned}
$$

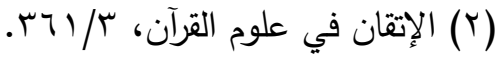

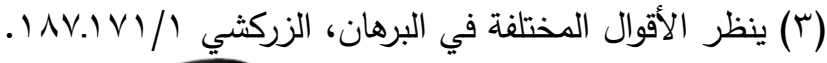


ثبت أنه كلام الله ـ تعالى .، وكأنه ـ سبحانه وتعالى . يقول لهم من خلال هذه الأحرف: ها هي ذا الأحرف الهجائية نضسها بين أيديكم مفردة كل حرف على حدة: أ ، ل ، م، ن ، ص ، ك ، هـ ، ، هي ... فخذوها وألفواً منها كلامًا مثل هذا القرآن! فإن عجزتم عن ذلك فاعلموا أن القرآن كلام الله !؛ قال الشيخ سيد قطب في توضيحه لهذا الرأي: "إنها إثارة للتنبيه إلى أن هذا الكتاب مؤلَف من جنس هذه الأحرف، وهي في متتاول المخاطبين به من العرب، ولكنه ـ مع هذا ـ هو ذلك الكتاب المعجز، الذي لا يملكون أن هذئ يصوغوا من تلك الحروف مثله. الكتاب الذي يتحداهم مرة ومرة ومرة أن يأتواً بمثله، أو بعشر سور مثله، أو بسورة مـن مثله، فـلا يملكون لهذا التحدي

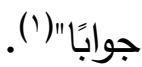

\section{الفعل الإنجازي المتضمن في القول : - المئ}

إن إنجاز الأفعال الكلامية قد يكون بالمعنى الحرفي الدصرح به في

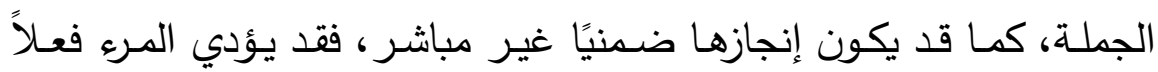
كلاميًا بصـورة غير مباشـرة تسمى بالأفعال الكلاميـة غير المباشرة، وهنـاك أنواع أخرى من الحالات حيث يختلف معنى الجملة نسقيًا عن المعنى الذي يقصده المتكلم، وقد أسهمت الحروف المقطعة في القرآن الكريم في انسجام تراكيبه، وفي جعله خطابًا حواريًا مبنيًا على المسـاءلة، كمـا أسـهم تتويـع

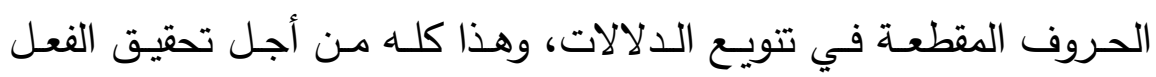

التأثيري

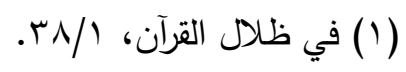


تعليق واستنتحــاجـاج

كما أن نظم القرآن الكريم معجز فبحرفه معجز ، وكل ذلك لأسـرار إلهية وأغراض نبويـة، وإنما خفيت على الناس؛ لأنها أسرار باطنية لا تدرج إلا بالفتح الربـاني، فهي بمنزلة الألفاظ، والحروف المقطعة التي في أوائل السور ، فإن لها أسرارًا عظيمة ومعاني كثيرة. ثانياً : ـ تعجيز من الله ـ عز وجل ـ لليهود:

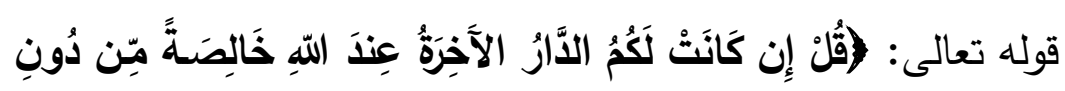

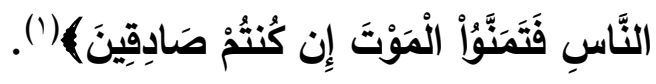

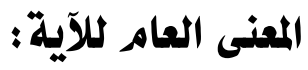

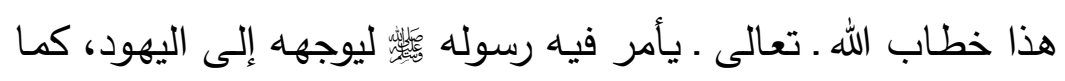

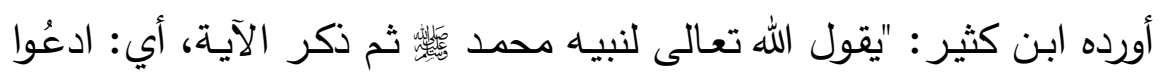
بالموت على أيّ الفريقينِ أكذبَ"(r)، كما أن هذه الآية ردًا على اليهود أنهم يدخلون الجنـة ولا يشاركهم فيها المسلمون، والـلام في الناس للجنس، وربمـا

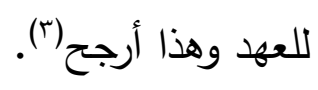

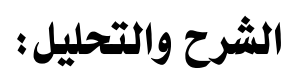
يخبـر المـولى . عـز وجـل ـ في هـذه الآيـة عـن اسـتمرار اليهود في

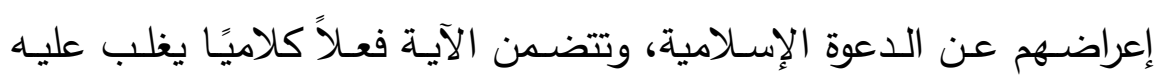

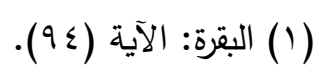

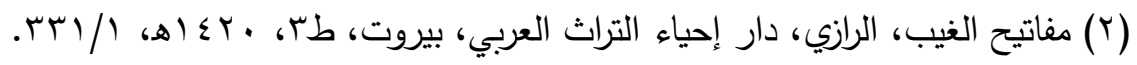

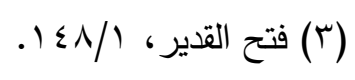


الإخبـار، وزيـادة على الإخبـار، فـإن هنـاك: تبكيـت وتعجيز ، وهذا الفعـل الكلامي يقدم صورة من طبيعة بني إسرائيل التي تأبى التغيير والتبديل. لقد اختار السياق القرآني الفعل الكلامي، الذي يشكل البنية الحواريـة الحجاجيـة في هذه الآيـة، "إن الوظيفـة الإقناعيـة من وظـائف البلاغـة؛ لأن تأثيرها التداولي أقوى"(')

\section{ـ الفعل الإنجازي المتضمن في القول:}

في هـــا الموقـف الحـواري اسـتعمل القـرآن الكـريم معنـى التعجيـز والتحدي، وجعل للفعل الإنجازي موقفًا ملائمًا يقتضيه السياق، وهو تحقيق فعل متضمن في القول هو التكذيب وإبطال الدعوى بدخولهم الجنة من دون

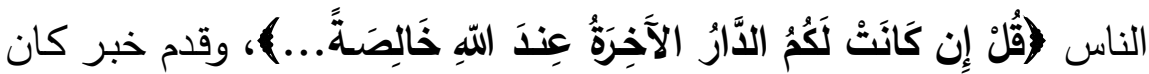
لغرض تداولي هو الاهتمام بأمر المتقدم أو إفادة الحصر لتقويـة التأكيد، ثم

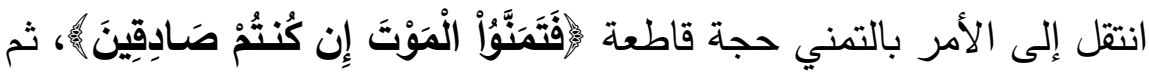
يختم هذه المحاجة بالجواب الحاسم، مستعملاً الإخبار في قوله تعالى: (وََلَن

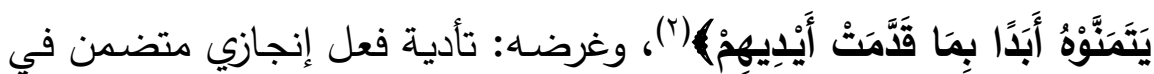
القول، هو التحدي والتعجيز، وهي جملة اعتراضية غير داخلة تحت الأمر

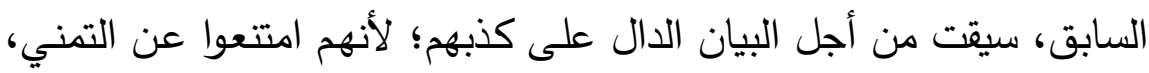
وقد ساهمت الجملة الاعتراضية بعقوبة كذبهم، وإظهاره، ونفي التمني عنهم "موجه إلى النبي

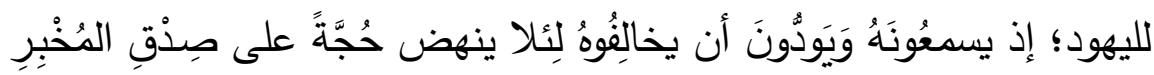

(1) استراتيجيات الخطـاب، مقاربـة لغويـة تداوليـة، عبدالهادي بـن ظـاهر الثـهري، دار

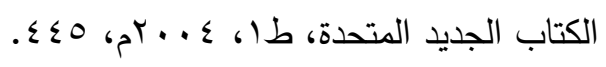

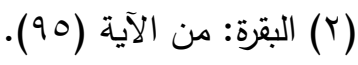




\section{الأفعال الكلامية في آيات التمجيز في القرآن الكريم دراسة تداولية}

بـهـ فيلزَمهُم أن الـدار الآخـرةَ ليسـتُ لهُم" (')؛ وبـذلك يتحقق للحجـة القرآنيـة غرضـها، وبالتالي فإن الحجـاج يـدعم القوة الإنجازيـة للفعل المتضـمن في التعجيز، ومـا يحمله من معنى الذم والتحدي، ومن ثم إسقاط ودحض كل

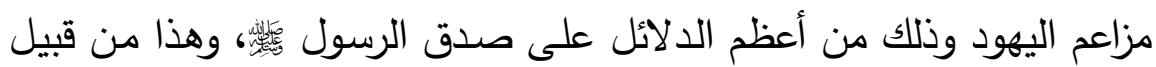
الإعجاز النفسي في القرآن الكريم(؟).

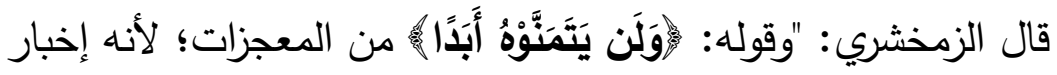
بالغيب، وكان كما أخبر بـه كقوله "ولن تفعلوا" فإن قلت مـا أدراك أنهـ لـ لم

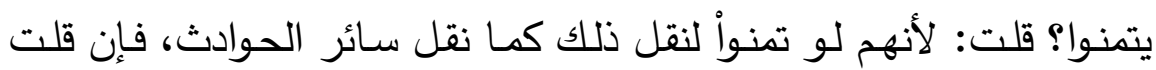
التمني من أعمال القلوب وهو سر لا يطلع عليه أحد، فمن أين علمت أنهم لـم يتمنـوأْ قلـ: ليس التمنـي مـن أعمـال القلـوب، إنمـا هـو قول الإنسـان بلسـانه: ليت ليّ كذا ...، ولو كان التمني بالقلوب وتمنواً لقالواُ: قد تمنينـا الموت في قلوبنا، ولم ينقل أنهم قالواً ذلك"(؟)، بينما نقل عن الصحابة قول بل ذلك كقول عمار بن ياسر بصفين: "اليوم نلقي الأحبة محمدًا وحزبَه"(๕)؛ ذلك بلك

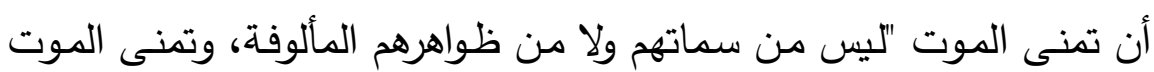

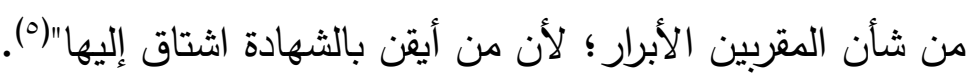

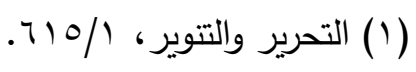

(Y) الإعجاز النفسي: "عدم مقدرة الكافرين أن يأتواً بكلام مثل القرآن في بلاغته وبيانه

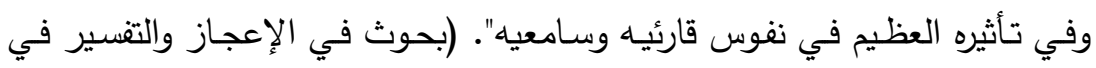

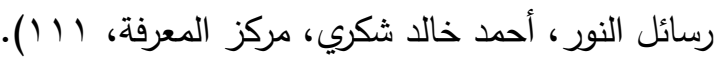

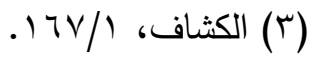

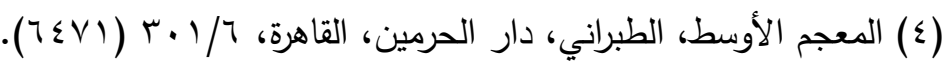

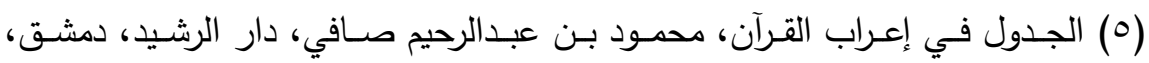

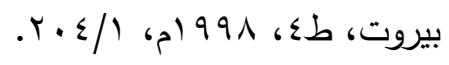




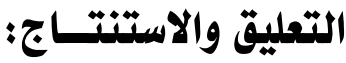

ا. الجملة الخبرية في الآيـة المذكورة استخدمت (لن) للنفي، منحت هذا الخبر من القوة الإنجازية ما تبطل به إنكار المنكرين.

r. الفعل الكلامي (فتمنوا) يحمل دلالة غير مباشرة، هي ذلك التعجيز

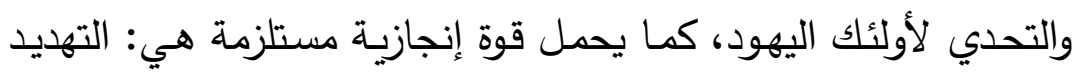

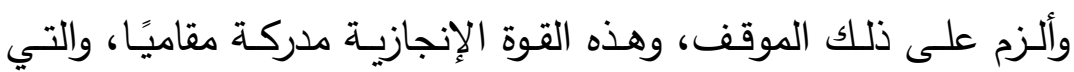

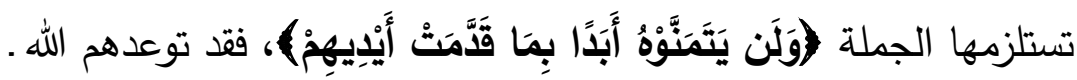
سبحانه وتعالى ـ بفعل حاصل في المستقبل هو عدم التمني. r. جاء التعجيز في السياق، وسيلة للدعم القوة الإنجازية المتعلقة بتهديد بني إسرائيل، هذا الفعل الكلامي غير ظاهر في البنية اللغوية، وذلك ما دلت عليه قرائن ظاهرية، وأخرى ضمنية استدلالية.

ثالثًا : تعجيز من الله ـ عز وجل ـ للملائكة (إقامة الحجة على الملائكة) :

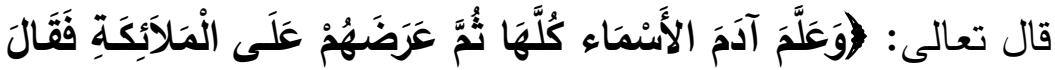

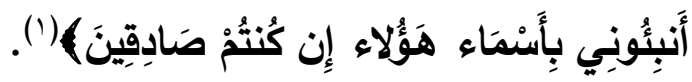

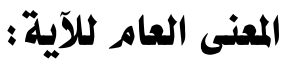

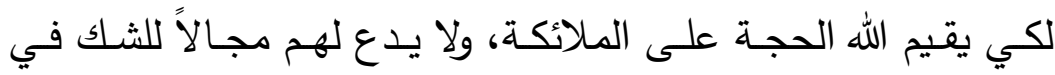
صلاح هذا الخليفة، عَلَّم آدم الأسماء كلها. "ذلك السر الإلهي العظيم الذي أودعـه الله ـ سبحانه وتعالى ـ هذا الكائن البشري، وهو يسلمه مقاليد الخلافة، سر القدرة على الرمز بالأسماء الألياء

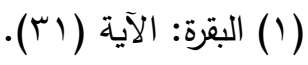




\section{الأفعال الكلامية في آيات التمجيز في القرآن الكريم دراسة تداولية}

للمسميات"(')، ولولا هذا السر مـا كان لسـلالته أن تتفاهم وتتعامل بسهولة ويسـر، فعلـم آدم أســاء الأشـياء كلهـا والظـاهر كمـا يقـول ابـن عاشـور : "والظاهر أن الأسماءَ التي عُلِّهها آدمُ هي ألفاظُ تدل على ذواتِ الأشياءِ التي يحتاجُ نوع الإنسان إلى التعبير عنها لحاجته إلى ندائها أو استحضـارها، أو أو

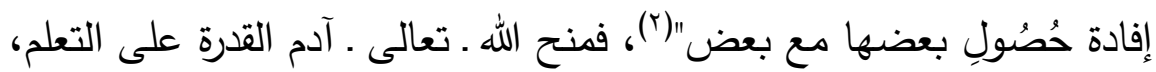
وأقدره على إيجاد الأسماء للمسميات.

\section{الشرح والتحـليل: - (الشيل}

هنا تقف الملائكة عاجزين منبهرة بفضل الله على آدم، ثم عرض الله هذه الأشياء على الملائكة ـ إقامـة للحجـة ـ إذ طلب منهم أن ينبئوه بأسماء المعروضـات بفعـل كلامسي تمثـل في الأمـر ، والغـرض منــه لـيس الأمـر الحقيقي، وإنما هو التعجيز والتحدي، وقوة الفعل وشدّته تكمن في المواجهة بالأمر (أنبئوني).

يقول الألوسي: "أنبئوني بأسماء هؤلاء تعجيز لهم وليس من التكليف بمـا لا يطاق"(r)، وقد قدّم هنـا جواب الشرط على الشرط المتمثل في قولـه

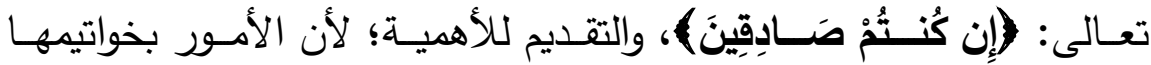
ونتائجها، لا ببدايتها ومقدماتها، فهاهو ذا سيدنا آدم يتحدى الملائكة بالعلم الـذي علمـه الله، ويستحق لـذلك أن يكـون خليفـة الله في الأرض "والإنبـاءُ

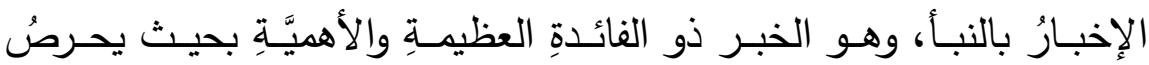
السامِعون على اكتسابه؛ ولذلك تضمن معنى الإنباء الإعلام؛ لأن المُخْبَر به

$$
\begin{aligned}
& \text { (1) في ظلال القرآن، أ. (1). } \\
& \text { (Y) التحرير والتتوير ، 9/ • ع. } \\
& \text { روح المعاني، / رrV/ }
\end{aligned}
$$




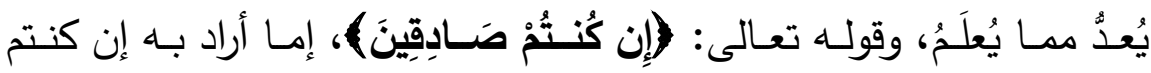
صادقين في أنكم أفضل من هذا المخلوق إن كان قولهج: ونحن نسبح ...،

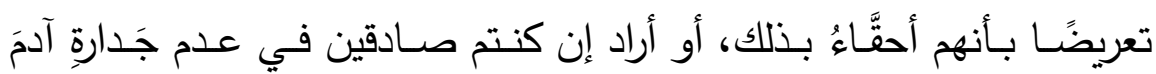

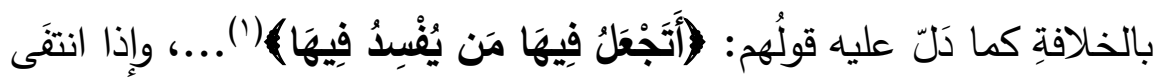
الإنباءُ انتفى كونُُهُ صادقين في إنكارهم خلافةَ آدمَ، فإن كان محلُّ الصدق هو دعواهُم أنهم أجدَرْ فقد ثبَتَ عَدمُهَا" (؟).

\section{ـ الفعل الإنجازي المتضمن في القول:}

تضمنت هذه الآية فعلاً كلاميًا توجيهيًا مباشرًا هو الأمر، تمثلت قوته الإنجازيـة الحرفية في طلب الأداء، أي طلب فعل شيء مـا، وهو أمـر الله تعالى لملائكته بأن يخبروه بالأسماء التي علمها لآدم، والدليل الإنجازي هو صيغة الأمر (أنبئوني)، أما القوة الإنجازية غير المباشرة المستلزمة(؟) مقاميًا فهي (التعجيز)، إذ يقول الزمخشري: "وإنما استنبأهم وقد علم عجزهم عن الإنباء على سبيل التبكيت"(؛)، والفعل التأثيري يتمثل في الرد على الملائكة ليعلموا الحكمة التي استخلف الله من أجلها آدم في الأرض، وليعلموا أن علم الله وسع كل شيء، كما أشارت الدراسات التداولية إلى دور الآمر في تتبيه المتلقي على خطورة ما سيأتي من أمور عليه أن يترقبها، ومن ذلك الدور

$$
\begin{aligned}
& \text { (1) البقرة: من الآية (•r). }
\end{aligned}
$$

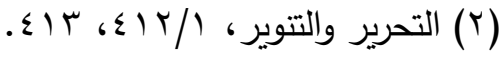

(r) الاستلزام الحهواري: "هي نظريـة في إنتاج الخطاب من خـلال التركيز على آليات الفعل الكلامي، تتحول من مرحلة الفعل اللغوي المباشر إلى مرحلة الفعل اللغوي

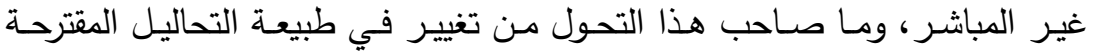

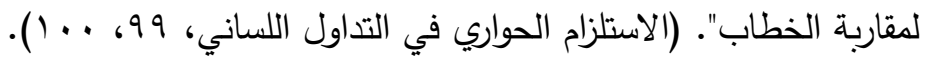

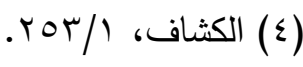




\section{الأفعال الكلامية في آيات التعجيز في القرآن الكريدر دراسة تداولية}

الذي يقوم به الخطاب والأمر في الآية "بما أن النبأ "إنما يطلق على الخبر الخطير والأمر العظيم"(') - (1)

ويرجع ذلك حسب تحليل (غرايس) إلى خرق قاعدة الكيف(؟)؛ لأن الله . سبحانه وتعالى . لا يريد أن يمتثل الملائكة لأوامره فهو يعلم أنهم عاجزين

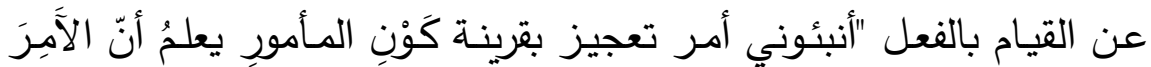
عَالُِّ بذلك فليسَ هذا من التكليفِ بالمحالِ ... ثم إنّ ذلك المعنى المجازي

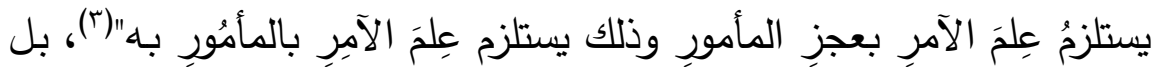
يرغب في إيصـال معنـى التعجيز ، فـاله ـ سبحانه وتعـالى . حين رأى مـن الملائكة علامـات رفض خلافـة هذا المخلوق تحدّاهم بـأن يخبروه بأسماء علّمها لسيدنا (آدم) ليثبت لهم أنه حقيق لهذه الخلافة وأنهم عاجزون عما هـاع يستطيع فعله (๕):

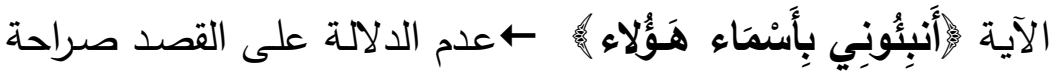
— خرق قاعدة الكيف ـ خروج الأمر إلى معنى التعجيز •

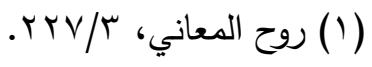

(Y) رأى غرايس أن العملية التخاطبية التي تقوم على التعاون الحواري بين المتخاطبين ترتبط بقواعد تخاطبيـة تضبط عملية الحوار من بين هذه القواعد: قاعدة الكيف ويقصد بها: منع ادعاء الكذب أو إثبات الباطل، وكذلك يطلب من المتكلم ألا يورد

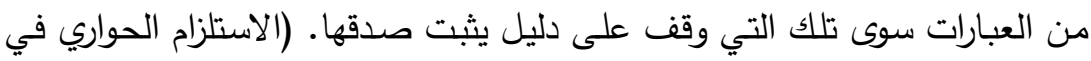

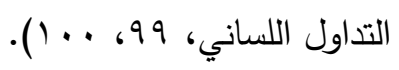

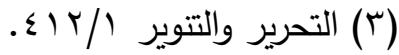

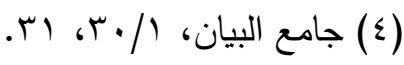




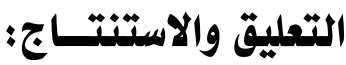

ا. كان التفاعل الحواري(') تفاعلاً إيجابيًا أدى إلى فعل إنجازي متعلق

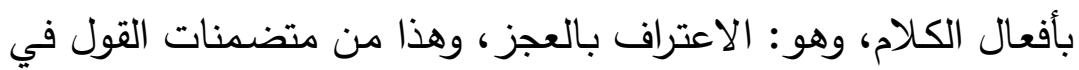

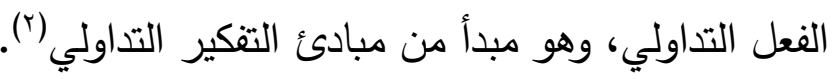
r. الأمر وإن كان ظاهره ظاهر أمر، فغير أمر على الحقيقة، بل المراد به

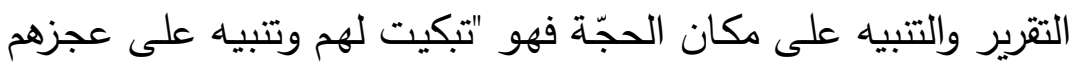

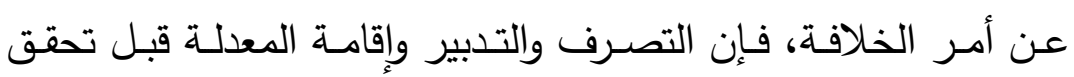

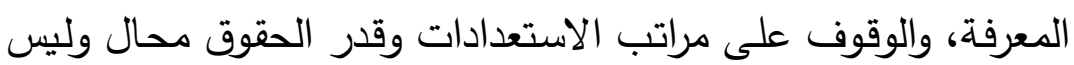

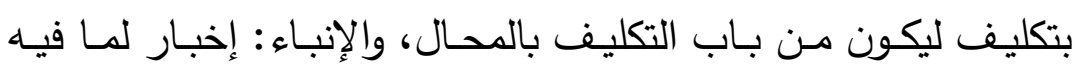
إعلام؛ ولذلك يجري مجرى كل واحد منهما"(").

رابعًا ـ تعجيز بعض الأنبياء ـ عليهـ السلام ـ لاققوامهم:

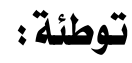

اقتضت حكمة الله ـ تعالى ـ ورحمته بعباده أن يختار بحصض فضله

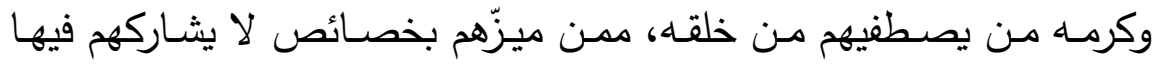

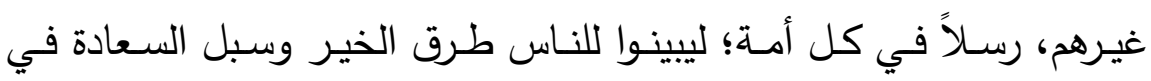

( (1) التفاعلات الحوارية تُبْلِ مقاصدها بمقتضى التعاون القائم بين أطراف الحوار ، وهو

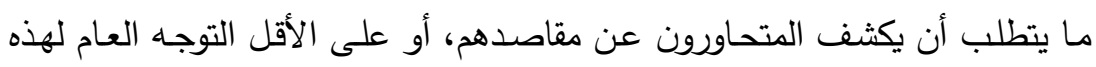

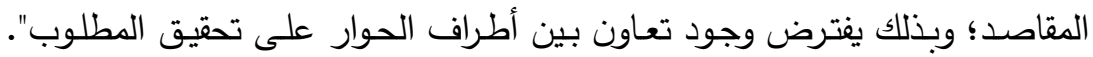

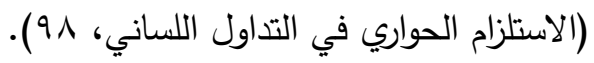

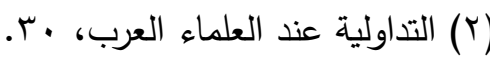

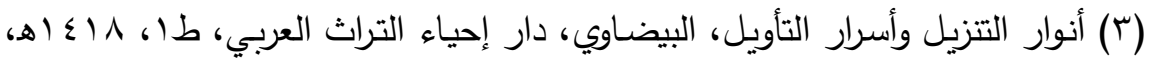




\section{الأفعال الكلامية في آيات التعجيز في القرآن الكريدردراسة تداولية}

الدارين، فيدعونهم إلى عبادة الله وحده، ويحذرونهم مـن عبادة غيره، وقد

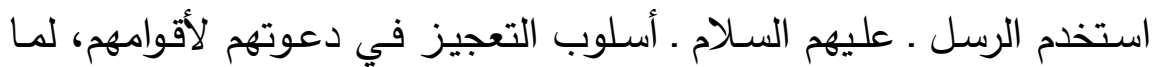
لهذا الأسلوب من نتائج طيبة وآثار إيجابية في الدعوة إلى الله تعالى، ومن الآيات الدالة على ذلك: - الك

\section{ـ تعجيز من موسى الئليله لقومه :}

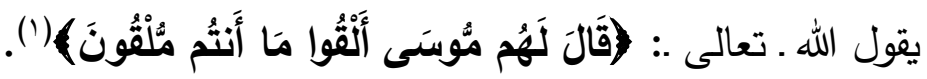

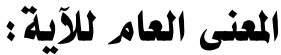

لم يرد استئذان السحرة لموسى الئليَّ) في هذه السورة (الشعراء)؛ لأنها

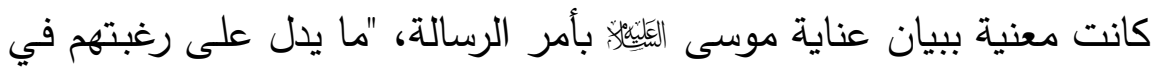

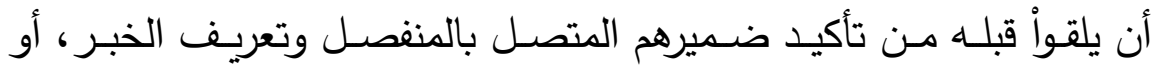
تعريــف الخبر وإقحسام الفصل، وقد سوّغ لهم موسىى مـا تراغبواُ فيـه، ازدراء

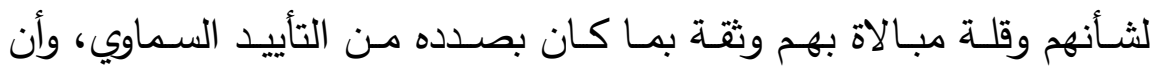

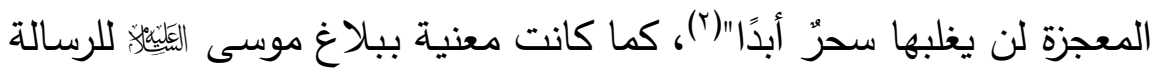

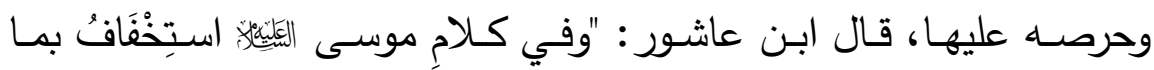
سَيْلْقُونَه؛ لأنها عبَّر عنه بصيغة العموم، أي ما تستطيعون إلقاءَهُ"(").

\section{الشرح والتحليل : - الشيل}

فطن موسى الئليَّة) إلى خبث فرعون وهدفه، فلجأ إلى ما نعرفه اليوم في اللســانيات وتحليـل الخطــاب (بقـوة التســاند الحجــاجي وســلمية التـدرج

$$
\begin{aligned}
& \text { (1) الثعراء: الآية (r؟). }
\end{aligned}
$$

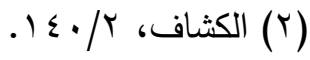

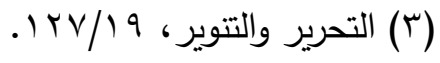




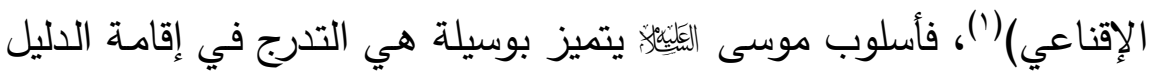
والحجة، وعدم إدراج كل البراهين والحجـج دفعة واحدة، بل الاقتصـار على الضروري منها حسبما يتطلبه الموقف، وتقتضيه الحاجة إلى البيان والإقناع أو الرد، ومن ثم التأثير على الحاضرين الذي يمثل الهدف العام للتعجيز .

\section{الفعل الإنجازي المتضمن في القول :}

الفعل الإنجازي يؤدي على نحو غير مباشر من خلال فعل إنجازي

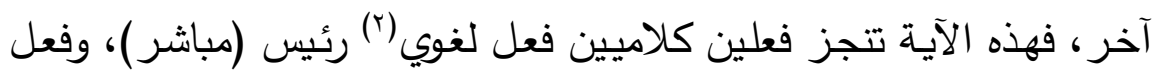
لغوي ثانوي (غير مباشر)، ويمكن للفعل الثانوي أن يرد داخل بنية التدخل(r) قبل الأفعال الرئيسة أو بعدها أو فيما بينها.

(1) قَعَّد لمسألة الحجاج كل من (جون أوستين)، و(جون سيرل) ضمن نظريـة الأفعال

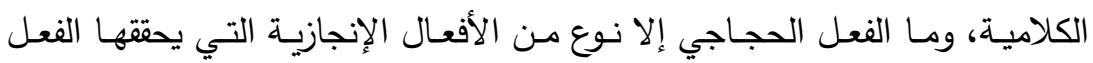

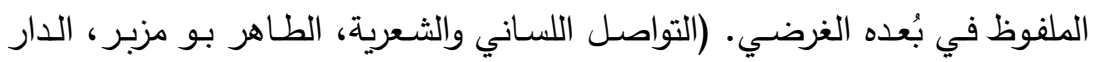

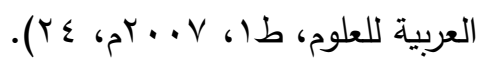

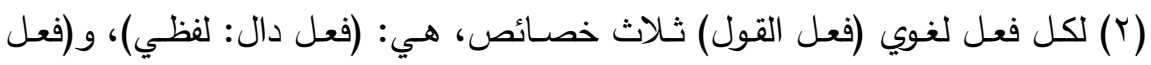

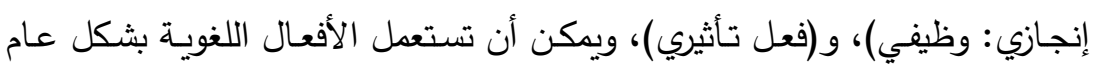

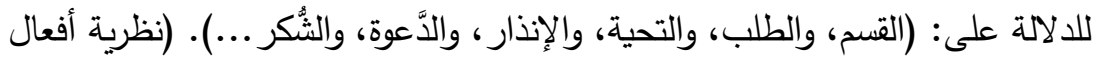

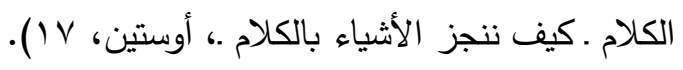

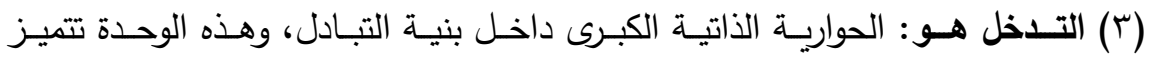

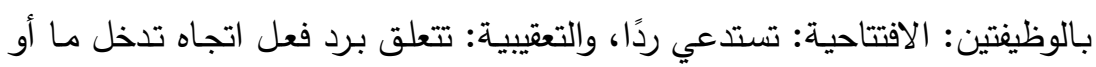

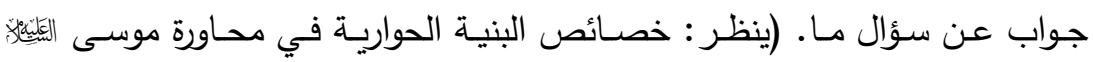
لفرعون وأسسها الحجاجية، د. بو شعيب بن مسعود راغين، جامعة طيبة، المدينة

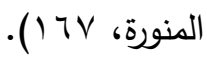




\section{الأفعال الكلامية في آيات التعجيز في القرآن الكريدر دراسة تداولية}

"إن القول ليس هو دائيًا القول تصـريحًا، فالنشاط الخطابي شـاملاً باستمرار بين المقول وغير المقول، وليس أقل فوائد التداولية إعطاء الجمل التضمينية أحقية كاملة، ابتداءً من المقولة التقليدية عن الحذف في التركيب،

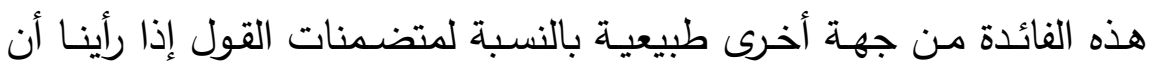

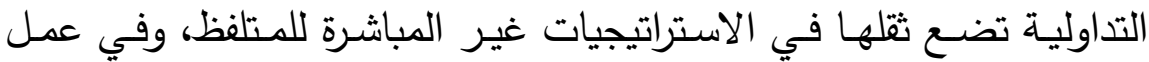
تأويل الملفوظات عند المتلفظ المشارك"((). هذه الوظيفة التفاعلية المسندة إلى الفعل (ألقواً) حجة تعجيزية تمنح حضورًا لفهم الآليات المتحكمـة في انتظامـه الخطابي اللسـاني والتداولي،

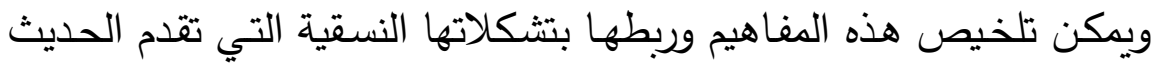
عنها كالتالي: - الي التبادل > = التدخل > الأفعال اللغوية (الإنجاز الخطابي)

$$
\text { وكل تذخل له وظيفتان: }
$$

تعقيبية: تستدعي رد الفعل تجاه تدخل ما ذي وظيفة افتتاحية، أو جواب

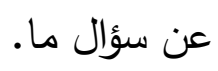

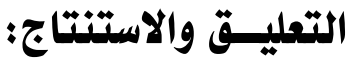

تصور الآية حالة من العناد الجامح كالذي يؤْبر الهلالك على الإذعان

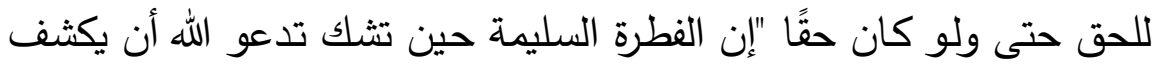

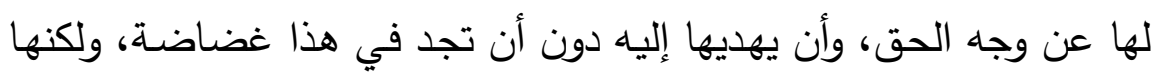

( (1) تداولية الخطاب السردي: دراسة تحليلية في وحي القلم للرافعي، محمود طلحة،

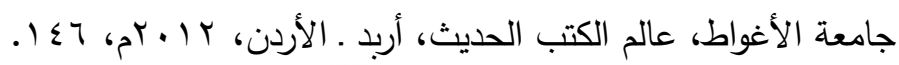


حين تفسد بالكبرياء الجامحة تأخذها العزة بالإثم حتى لتؤثر الهلاك والعذاب

على أن تخضع للحق" (').

خامساً ـ تعجيز من بعض الأقواه لأنبيائهم ـ عليهم السلامــ:

توطئة:

التعجيز لـم ينطلق إلا في إطـار الجـو الذي يملك المشـركون أمـر

التحرك فيـه، وهو الجانب البياني، أمـا الجـانبين العلمي والغيبي فههـا مـن إلن

الجوانـب التي تنهض دليلاً على صـدق القـرآن الكـريم، وليس في إطـار التعجيز؛ لأن التعجيز لا يعني شينًا في المجال الذي لا يملكون أمر المعرفة لـه، فقد يكون لهم أن يعتذرواً بعدم الاختصـاص، فيقولون: ليس ليس لنا القدرة على علم الغيب، فهي سـالبة بانتفاء الموضوع، بـل يطـارحهم القرآن حوارًا

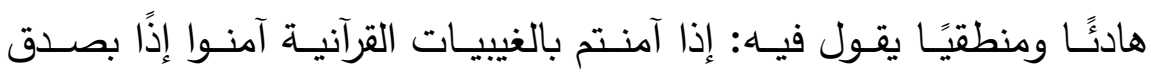

قائلها (r).

ومن هنا لا يمكن أن تكون قضايا العلم والغيب مجالاً للإعجاز وإن

كانت دليلاً على صدق رسالة الرسول فئس

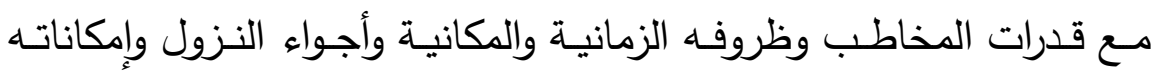

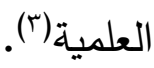

(1) في ظلال القرآن، / 10.0.

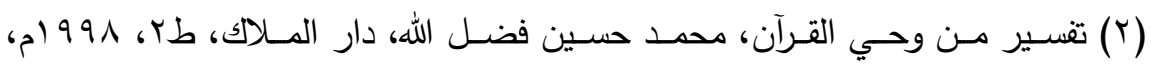
$.11 \leq / 1$

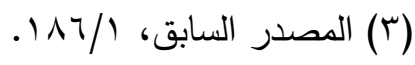




\section{الأفعال الكلامية في آيات التمجيز في القرآن الكريم دراسة تداولية}

إذًا، فالإعجاز البياني هو وحده الحاضـر على سـاحة تعجيز الكفار والمشركين، أو تعجيزهم للأنبياء، ومن الآيات الدالة على ذلك: ـ تعجيز من الكفار للنبي :

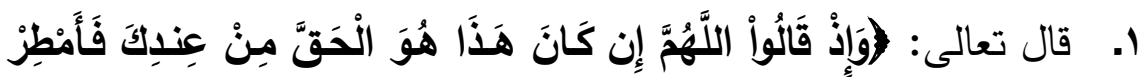

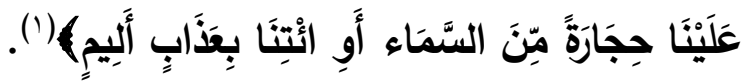

المعنى العام للآية :

نقل الألوسي عن أهل العلم "أن قريشًا قال بعضـها لبعض أكرم الله

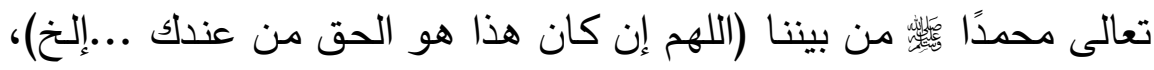
وهو أبلغ في الجحود من القول الأول؛ لأنهم عدُّواْ حقيته محالاًا(ب)، فتحدَّواً بدعائهم هذا قدرة الله عليهم في أن يأتيهم بعذاب، كما كان الثأن مـع الأقوام الذين من قبلهم ودلالة الدعاء تحيل على استهزائهم وتعجيزهم للفعل الإلهي.

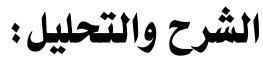

كلامُ الكفار في هذه الآيـة المباركة "جار مجرى القسم ...، فمعنى

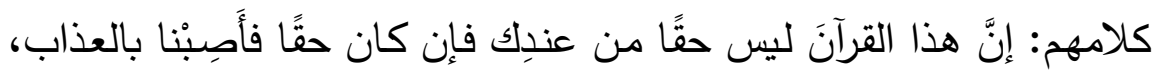

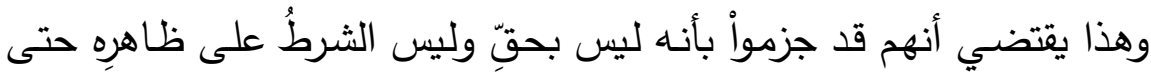

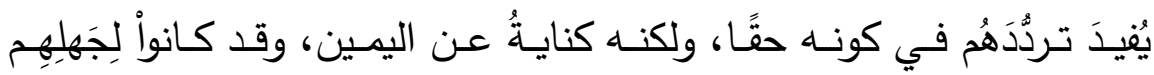

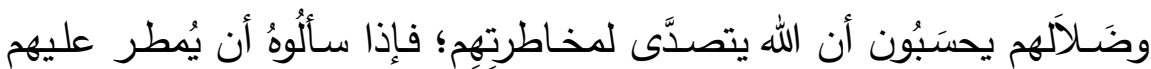
حجارة إنْ كان القرآنُ حقَّاً منّه أمطَرَ عليهُ الحجارةَ وأرادواُ أن يُظهِرواْ لقومِهِح

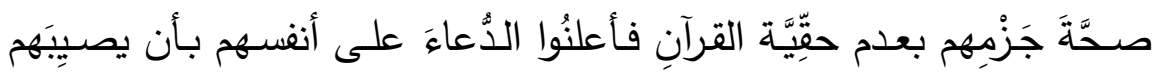




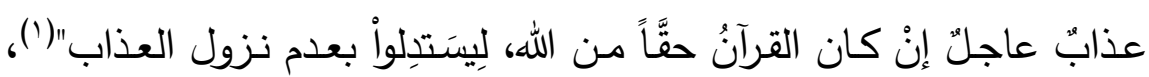

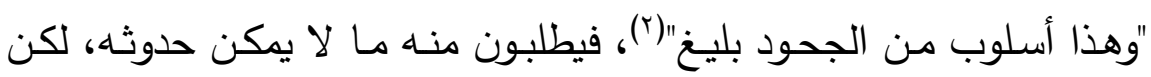
الرسول بشر ، أو لكون ما يطلبونه يخالف سمة صاحب الرسالة.

\section{الفعل الإنجازي المتضمن في القول :}

نلمح في النص المبارك إثارات عجيبة تدل على ورود الفعل الكلامي (أمطر)، (آتتا)، بصيغة الأمر ، وذكر ابن فارس أنه لا يقال: (أُمْطِرَ) إلا في

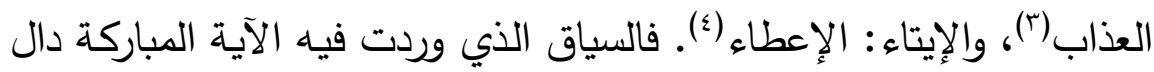
على أن فعل الأمر (أمطر ـ آت) ليس في معناهما الحقيقي، وإنما يراد بهما معنى غير مباشر وهو الدعاء، والسخرة، والاستهزاء، والاستخفاف، بالإضافة

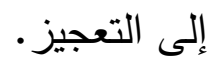

وتتجلى القوة الإنجازية للفعل الكلامي في:

· إذ) التي تفيد الظرفية، وفيها دلالة على القوة.

· واستعمال لفظ (اللهم) وهو مركب من لفظ الجلالة (الله) والميم التي هي عوض عن حرف النداء (يا)؛ إذ لا يجمع بين (يا) والألف واللام إلا مـع لفظ الجلالة خاصة، وهو دليل على عظمة وتفخيم اسمه تعالى.

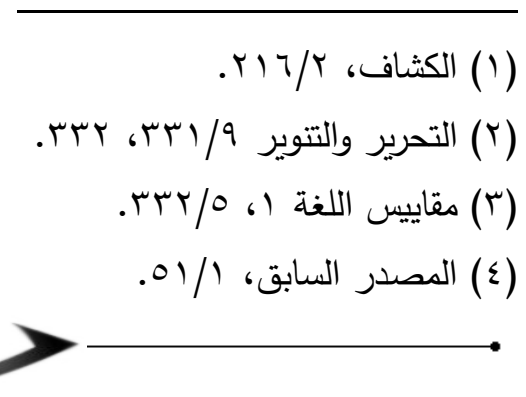




\section{الأفعال الكلامية في آيات التعجيز في القرآن الكريدر دراسة تداولية}

· ت تعليق الشرط بحرف (إنْ)؛ لأن الأصل فيها عدم اليقينِ بوقوع الشرط، فهم غيرُ جازمينَ بأنَّ القرآن حقُّ ومُنَنَّزلْ من الله، بـل هم موقنون بأنَّهُ غيرُ حقّ، واليقينُ بأنهُ غير حقّ أخصُّ من عدم اليقين بأنَّهُ حقُ. · استعمال ضمير الفصل (هو) فهو يقتضِي تقوِى الخبر . · تعريـف المســـ (الحـق) بـلام الجنس يقتضـي الحصـرَ وذلك تعبيـرهم

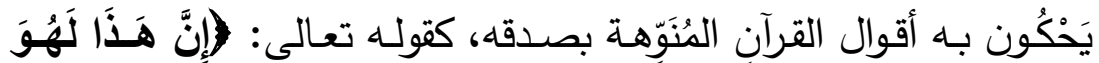
الْقَصَصُ الْحَقُّ)(') ...، وهذا الدعاءُ كنايةُُ منهم عن كونِ القرآن ليس

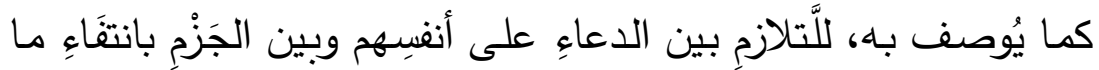

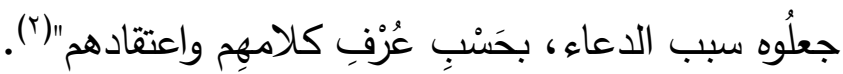
· استعمال شبه الجملة الظرفية (من عندِك) الواقعـة في محل الحال من الباري • سبحانه وتعالى ي؛ إذ هم يطعنون ويجحدون كونـه مَنزَّاً من عند

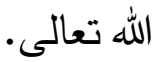
• استعمال فعـل الأمـر (أَمْطِز ) الـذي يـدل على قـوة شـديدة متأتيـة مـن استعماله بصورة غير مباشرة بالدعاء على أنفسهم. · العطف الذي يعطي قوة للجملـة العربيـة وزيـادة في التأكيد (آتنـا على أمطر)، والمراد بهذا الدعاء هنا التهكم والسخرية وإظهار اليقين والجزم

التام على كونه باطلاًً) (r).

$$
\begin{aligned}
& \text { (1) آل عمران: من الآية (rآ). }
\end{aligned}
$$

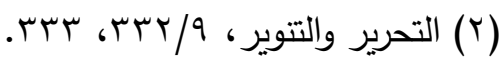

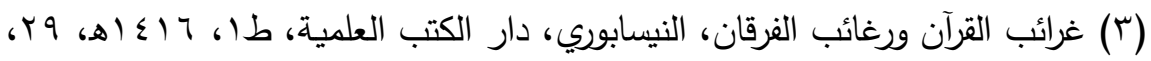

$$
\text { . }
$$


وممـا يُزاد على مـا تقدم يمكن تجلية القوة الإنجازيـة للفعل الكلامسي المُؤديّي الأمريّة غير المباشرة في ضوء ما يأتي:

المحتـوى اللفظــي ('): إذ قـالوا اللهـم، والجملـة الشـرطية (إن كـان) وضـمير الفصل (هو)، والألف والـلام الجنسية (الحق) وشبه الجملـة (من إلـ عندلك)، الفاء (أمطر، آنتنا)، واو العطف، عذاب، أليه. والمحتوى القَضَوِيّ(؟): إنكار الكافرين وجحودهم بأن ما جاء بـه النبي

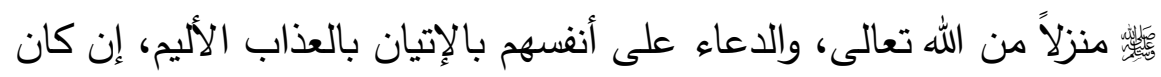
ذلك حقًا.

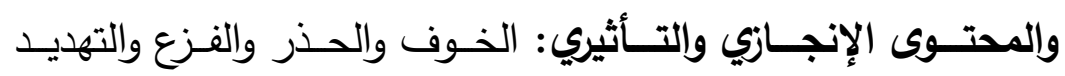

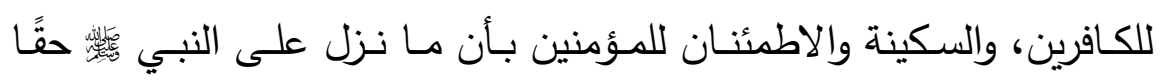
مصدقًا، وكذلك الخزي والعار للكافرين في الآخرة.

(1) المحتوى اللفظي (الفعل النُطقي): وهو يشمل الجوانب الصوتية والنحوية والمعجمية، وهو يضم كل من الفعل الصوتي والتركيبي عند أوستين.

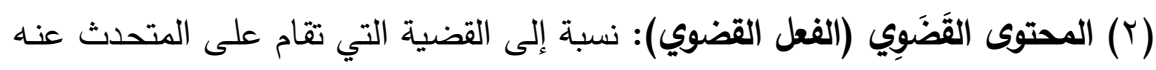

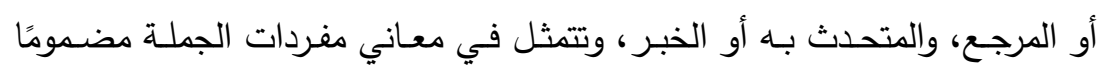

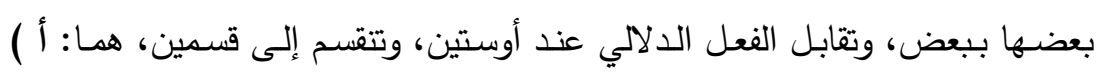

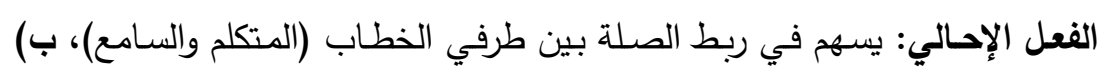

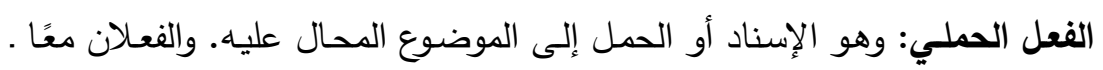

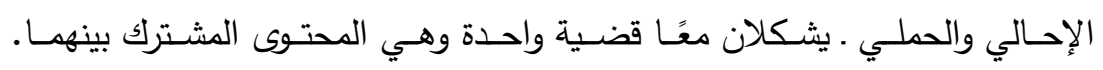

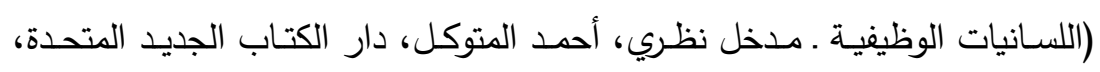

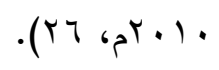




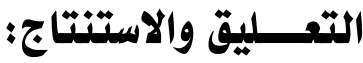

طالعنا النص القرآني الكريم بصورة تعجيزيـة تجسدت وفق نمطين من

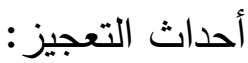

الــنمط الأول: تحدى المعانـدين للإبــلاغ الرسـالي خـلال محاكـاتهم

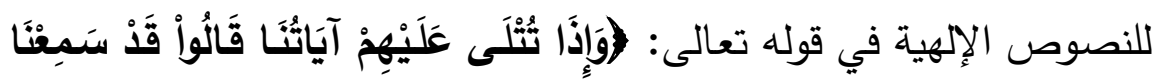

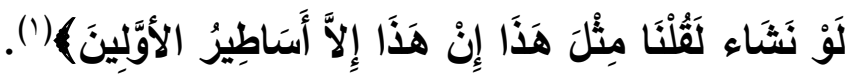

النمط الثاني: تحدى المعاندين لأنفسهم لتحقيق هلاكهم إن كان هناك

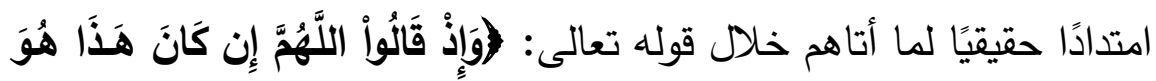

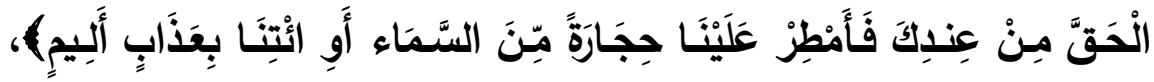

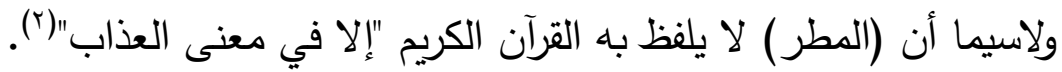

ويبدو أن محور التعجيز المتمثل في صورة الحجر الساقط من السماء

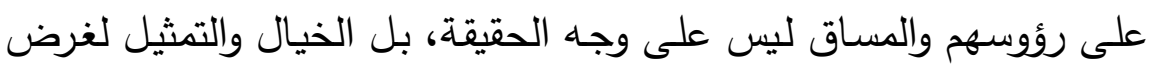
وعظ المعاندين من أنّ الله تبارك وتعالى لديه قدرة على الإطاحة بالمعاندين

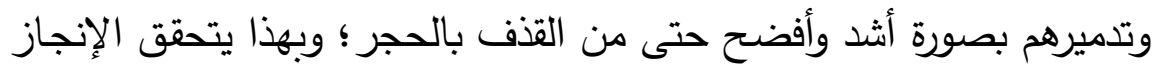

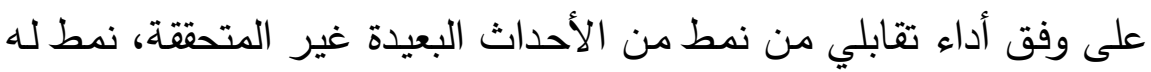

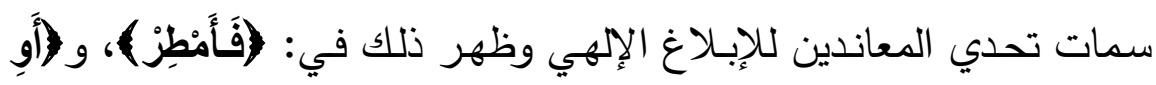

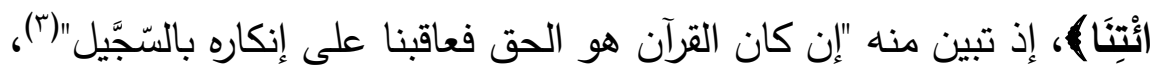

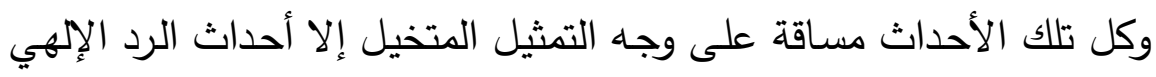

$$
\begin{aligned}
& \text { (1) الأنفال: الآية (Y) (Y). } \\
& \text { (Y) الكثاف T/ T/ }
\end{aligned}
$$

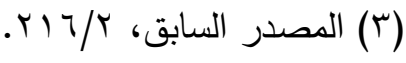


جمعت بين سمة المثل المقدس والحقيقة المساقة على سبيل وعظ المعاندين بالابتعاد عن التحدي بفعل فرط أنغتهم واستناكفهم أن يغلبواْ (').

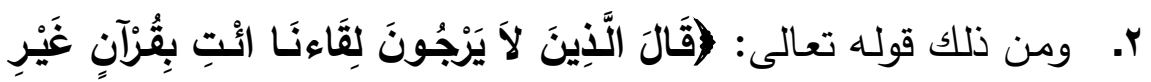

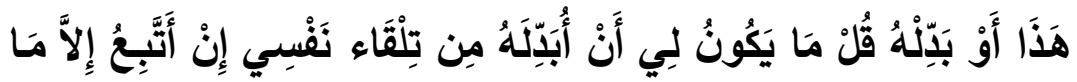

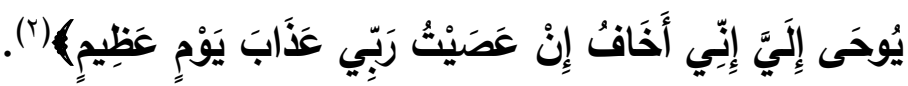

\section{المعنى العام للآيةه:}

قال الإمـام الزمخشري: "غاظهم مـا في القرآن من ذم عبادة الأوثان والوعيد للمشركين، فقالوأ: ائت بقرآن آخر ليس فيه ما يغيظنا من ذلك نتبعك

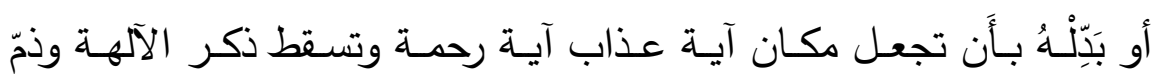

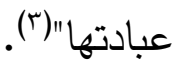

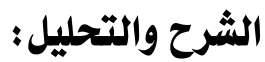

خاطب الكفـار رسول الله

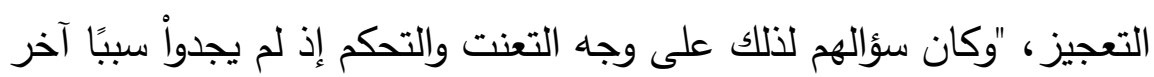
يتعلقون به"(؛)، وفي اختيارهم فعل الإتيان تتاقض بين غرضههم وهو تعجيز

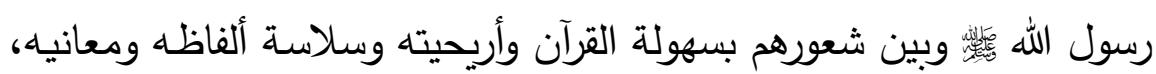

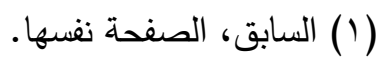

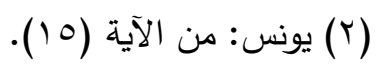

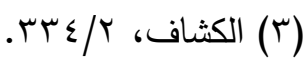

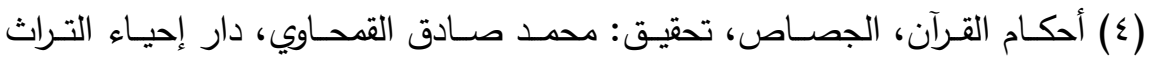

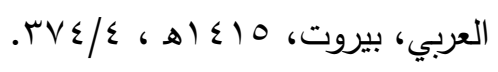




\section{الأفعال الكلامية في آيات التعجيز في القرآن الكريمدراسة تداولية}

فمن المقرر أن الإتيان "مجيء بسهولة ويتصل بالسهولة معنى الاستجابة

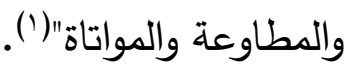

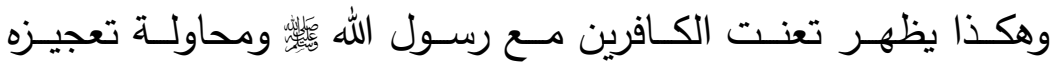
والاستهزاء به، "وهو طلب عجيب لا يصدر عن جد، إنما يصدر عن عبث وهزل وعن جهل كذلك بوظيفة هذا القرآن وجدية تنزيله ...، وأغلب الظن أن أولئك الـذين لا يتوقعـون لقـاء الله كـانواُ يحسبـون المســألة مســألة مهـارة، ويأخذونها مأخذ المباريات في أسواق العرب في الجاهلية ..."(؟).

\section{الفعل الإنجازي المتضمن في القول : - المئ}

الفعل (فأت) قوته الإنجازيـة كامنة فيه، تضـافرت عوامل لغويـة أخرى

لتزيـده قـوة أخـرى؛ لتفصـح الآيـات عـن انطبـاع نفسي خبيـث عنــــــــاء الجاحدين وحقد متجذر في قلوبهم على الله ورسوله وقرآنه، ومن ذلك:

وضـع المظهـر موضـع المضــر : كـان مقتضـى الظــاهر أن يعبـر بالضمير فيقال مثلاً: وإذا تتلى عليهم آياتنا بينات قالوا ... لكنه عبر بالاسم الموصول: (قََالَ الأَنِينَ) ليشير إلى أبرز صفاتهم وعلة إنكارهم وهي تتمثل في جحودهم لقاء الله حيث يظهر "وحي الكلمة وعملهُا بما يثيره لفظها من شئون في النفس لا يستطيعها الضمير العائد عليها، فالضمير لا يعمل في العقول عمل الإفصاح والتكثيف"(r).

(1) الإتيان والمجيء فقه دلالتهما واستعمالهما في القرآن الكريم، محمود موسى حمدان،

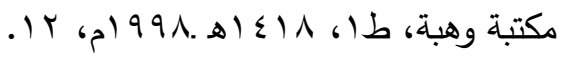

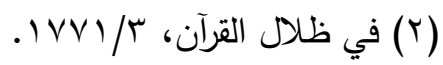
(r) خصائص التراكيب: دراسة تحليلية لمسائل علم المعاني، د. محمد محمد أبو موسى،

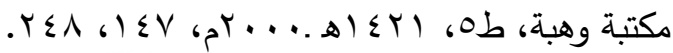




\section{التعليق والاستنتاج: - الت}

امتازت الآيـة القرآنيـة ببعض الصفات الميزة، منها: البنـاء اللغوي: جـاء التعجيز مبنيًا بنـاءً استـلاليًا يـتم فيـهـ اللجوء إلى الحجـة والاستـلال والمنطق والعقل معتمدًا على الأبنية والوسـائل اللغويـة، فقد وظف الخطاب القرآني وسيلة لغوية لتحقيق الإمتاع، وهي: وضع المظهر موضع المضمر .

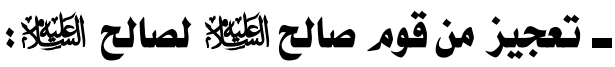

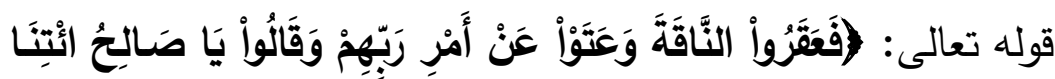

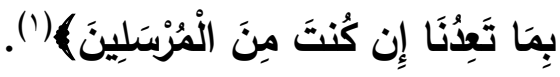

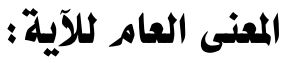

"فعقرت ثمود الناقة التي جعلها الله لهم آية وعتوا عن أمر بهم، يقول: تكبرواً وتجبرواً عن اتباع الله، واستعلوا عن الحق" (؟). الشرح والتحليل : - | (الشيل

ورد التعبير القرآني على سبيل التعجيز، فكان الجدل بين النبي صـالح

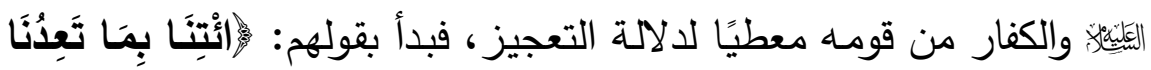

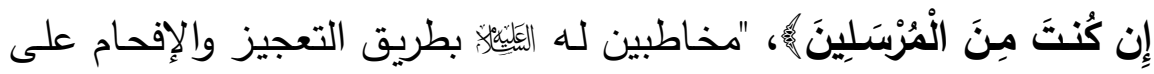

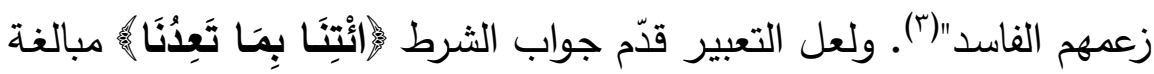

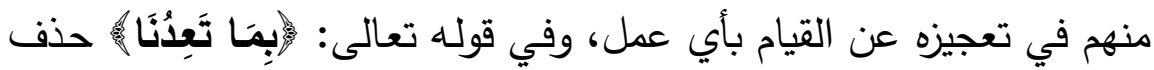

$$
\begin{aligned}
& \text { (1) الأعراف: الآية (YV). }
\end{aligned}
$$

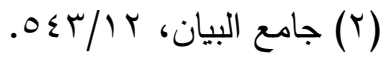

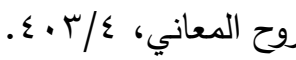


تقديره: بمـا تعـدنا "مـن العـاب وأطلق للعلم بـه"(')، ثم جـاء قولـه: (إنِ)

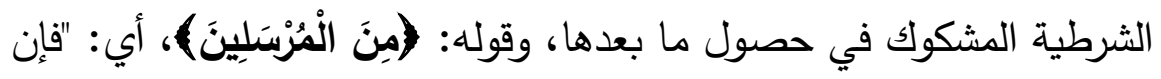
كونك من جملتهم يستدعي صدق ما تقول من الوعد والوعيد"(r).

\section{الفعل الإنجازي المتضمن في القول :}

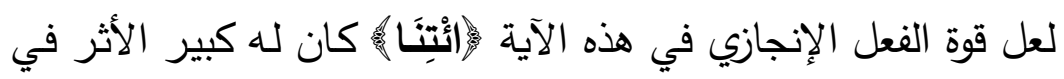

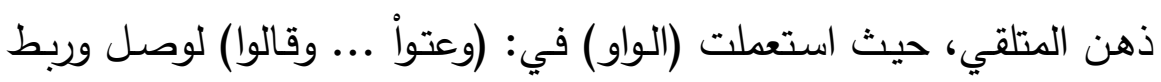
أفعال الكلام المختلفة من الرفض والتحدِّي. ومنـه تتضـح الطبيعة الإنجازيـة

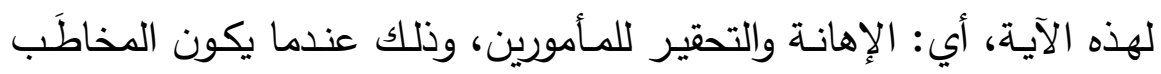
قليل الشأن في نفس الآمر، مع عدم المبالاة به؛ لذا لا يحمل على ظاهره؛

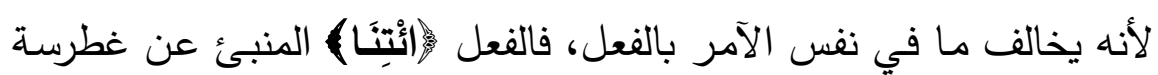

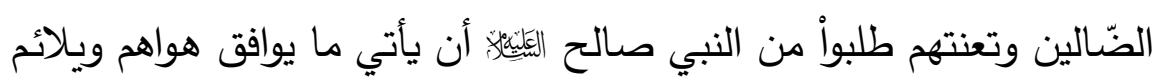
غرضهم "ولا يخفى على القارئ أن هذا محض الاستهزاء والسّخرية منهم"(؟).

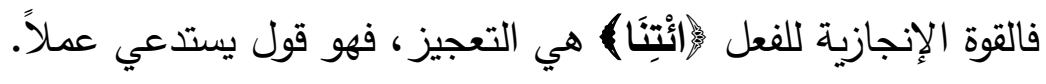

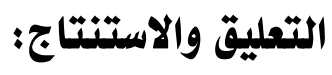
في الآية إثارة إلى:

ا. طبيعـة الأفعال الكلاميـة وتراتيُهـا، انطلاقًا من إنجازيتها المخصوصـة

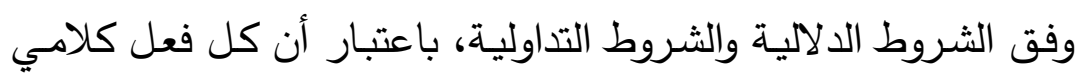

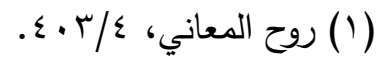

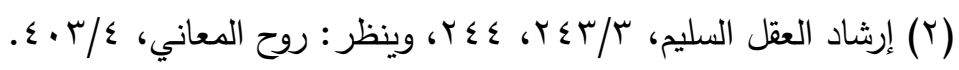

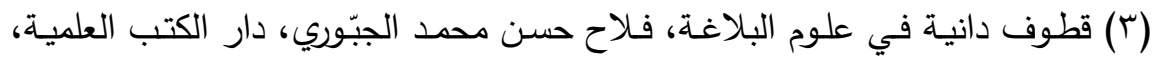

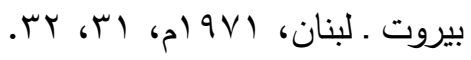


في الخطاب اللغوي المضبوط يهيئ وجود شرط الفعل الكلامي التالي له انطلاقًا من الحال الذي تعبر عنه من جهة، ومن الفرض الكلي لها

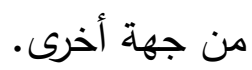

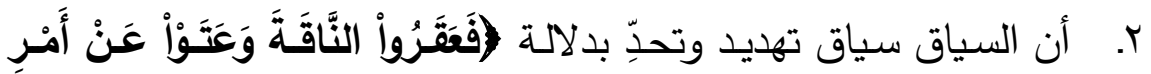

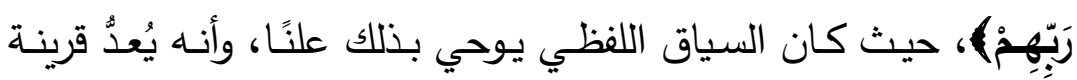
كاشفة لمعنى (ائتِنَا) )؛ لأن هذا المعنى ينسجم كليًا مـع الدلالة العامـة للسياق والتي تمثلت في المواجهة والتحدّي والتعجيز معًا.

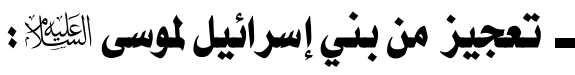

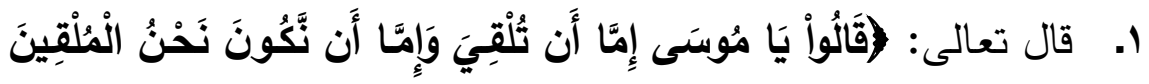

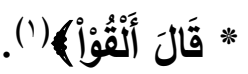

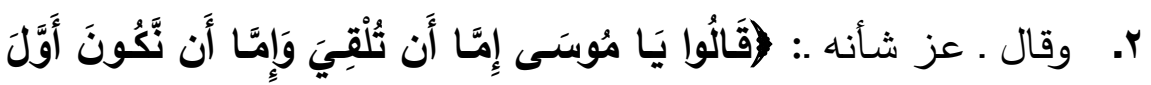

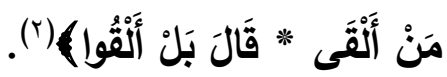

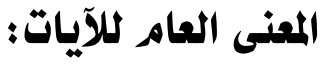

في سورتي الأعراف وطه، استأذن السحرة موسى الِيلِّنَّ في أيهما الذي يبدأ، ولـم يـكر الاستئذان في سورة الثـعراء، بـل اقتصـر على ذكر قول موسى للسحرة بالإلقاء، وسبب ورود ذكر الاستئان في الأعراف وطه، هو ما اختصت به سورة الأعراف من اقتصاص الخبر، وهي بذلك تسجل العظة

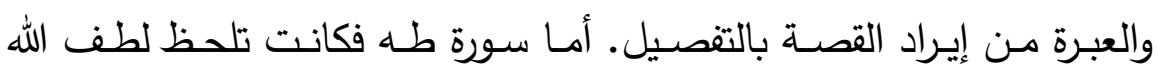
بموسى ومن هذا اللطف ما جرى بينه وبين السحرة فبدأت السورة خبره مـع

$$
\begin{aligned}
& \text { (1) الأعراف: الآية (10 (1))، ومن الآية (1 (1)). }
\end{aligned}
$$

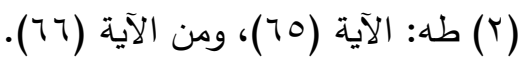




\section{الأفعال الكلامية في آيات التعجيز في القرآن الكريدردراسة تداولية}

الســحرة مـن أولـه، "تخييـرهم إيـاه أدب حسـن راعـوه معـه، كمـا يفعـل أهـل

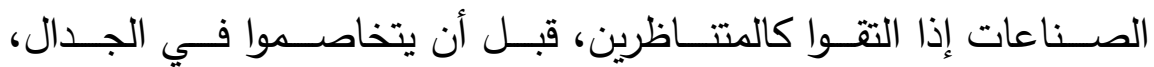

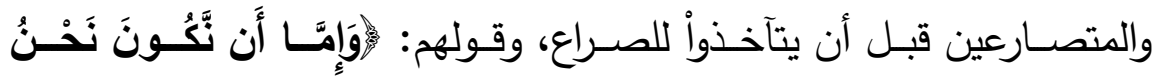

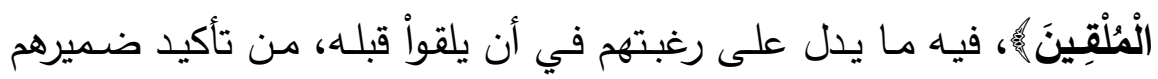

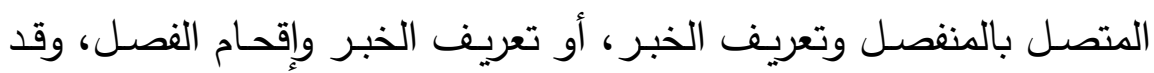
سوغ لهم موسى ما تراغبواً فيه، ازدراء لشأنهم وقلة مبالاة بهم وثقة بما كان بصدده من التأييد السماوي، وأن المعجزة لن يغلبها سحرٌ أبدًا"(').

\section{الشرح والتحليل : - | (الشيل}

"ابتدأ السَحَرةُ موسى بالتخيير في التقدُّم، إظْهارًا لثقتِهِهِ بمقدَرتهم وأنهم

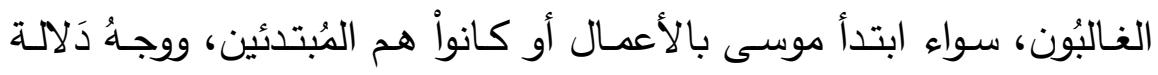

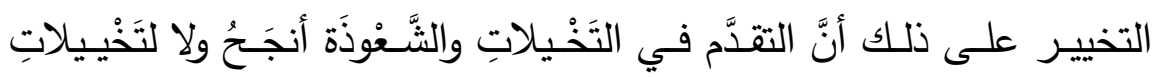

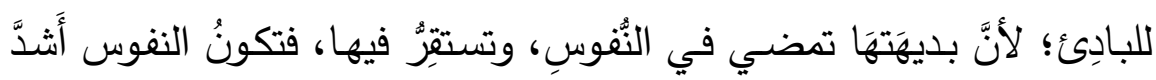
تأثرًا بها من تأثُّها بما يأتي بعدها، ولعلَّهم في ذلك أرادواً أن يَنْبُرُواْ مِقدَار

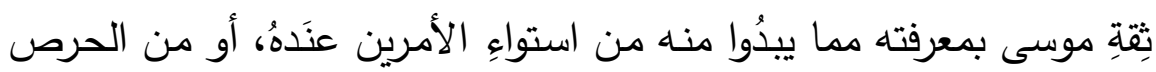
على أن يكون هو المقَدَّمَ، فإنَّ لاستضعاف النفس تأثيرًا عظيمًا في استرهابها

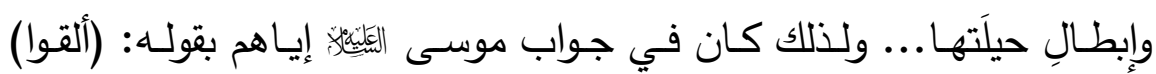

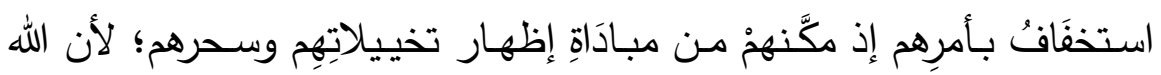
قَوَّى نَفْسَ موسى بذَلك الجواب لتكون غلَبتُُهُ عليهم بعد أن كانوا هُمُ المبتدئينَ

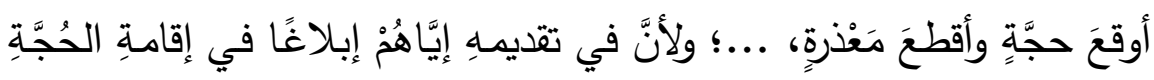

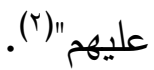

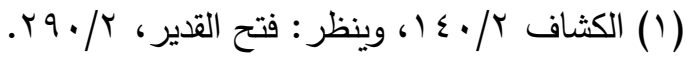

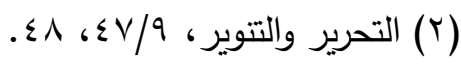




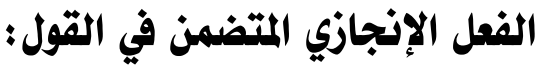

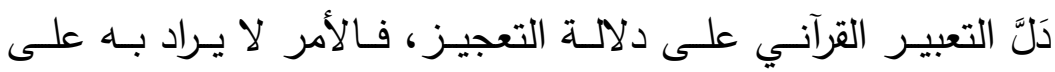

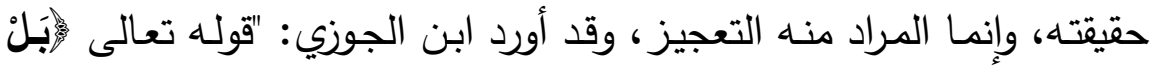

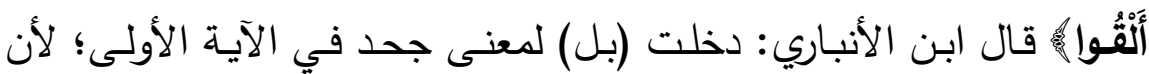
الآية الأولى إذا تؤملت وجدت مشتملة على إما أن تلقي وإما أن لا تلقي" ((').

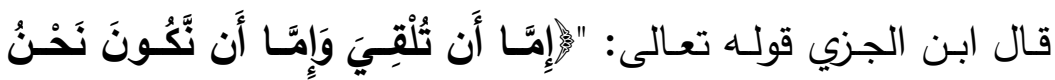

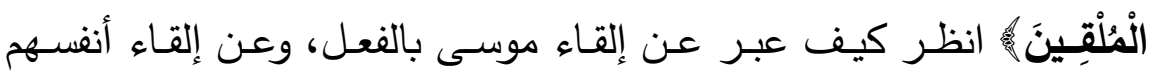
بالجملة الإسمية؟ إشارة إلى أنهم أهل الإلقاء المتمكنون فيه" (r).

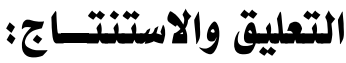

ا. تتوعت الأفعـال الكلاميـة الإنجازيـة في الآيتين السـابقتين، وتعددت

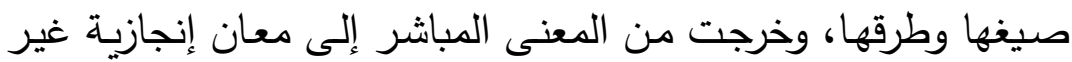
مباشرة يفسرها المقام الذي وردت فيه، وهو غرض التعجيز . r. كان النص الحواري في بنية كبرى من الأفعال الكلامية، تؤدي فعلاً

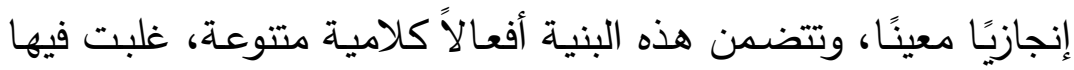
القوة الإنجازية غير المباشرة على القوة الإنجازية الصريحة.

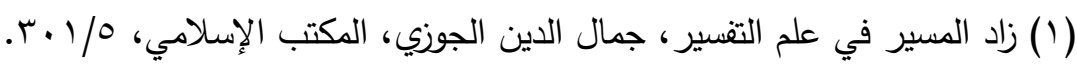

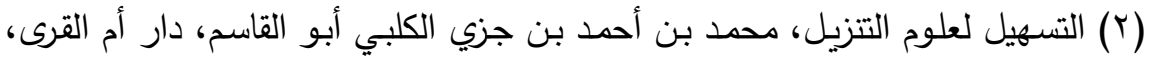

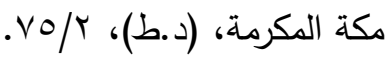




\section{المبحث الثاذي}

\section{الاثثر التداولي لأفعال الكلامر بصيخ مخصوصة للأمر}

\section{أولا ـ الأمر بصيغة أسماء الأفهال:}

\section{توطئــة :}

بعد عرض آيات صيغة الأمر الصريح، ها هي ذا صورة أخرى ووجها آخر للأكر ورد عن الأصوليين والنحاة الأوائل، وهي لون من ألوان الكلام عند علماء العربية، أدت وظيفتها من حيث الثكل والمضمون، وعملت على الهي

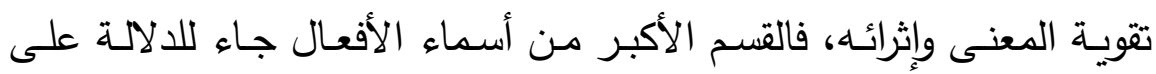

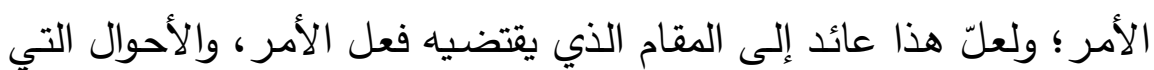
تستدعي المبالغـة والاختصـار في الطلب وهو "مـا نـاب عن الفعل معنى واستعمالاً ولم يتأثر بالعوامل ولم يكن فضله"(')، وقيل أسماء الأفعال هي:

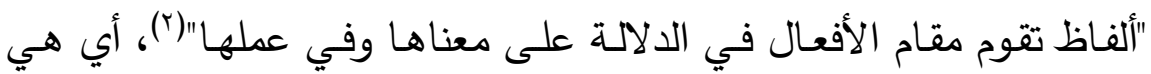
صيغ مخصوصة تقوم مقام الفعل في الدلالة والوظيفة، وهي مبنية دائمًا، فلا

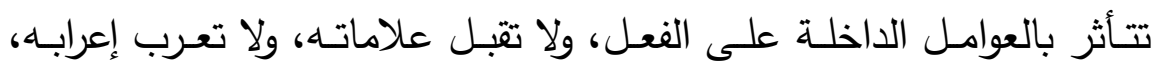
وتتقسم إلى ثلاثثة أقسام: اسم الفعل الماضسي، واسم الفعل المضـارع، واسم فعل الأمر (ז)، ومن هذا الأخير في آيات التعجيز :

(1) صور الأمر في العربية بين التتظير والاستعمال، سعود بن غازي أبو تاكي، دار

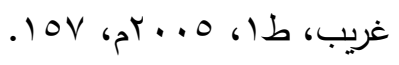

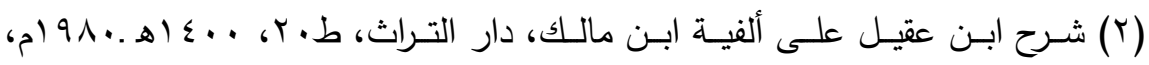

$$
r \cdot r
$$

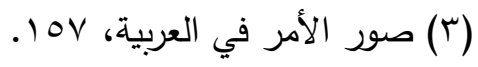




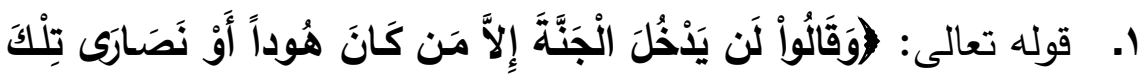

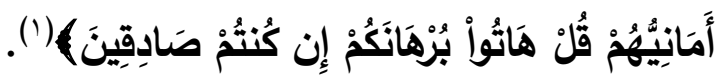

\section{المعنى اللغوي: - nمي:}

(هاتوا) اسم لفعل الأمـر بمعنى (أعطين) أو ما في معناه فهو غير

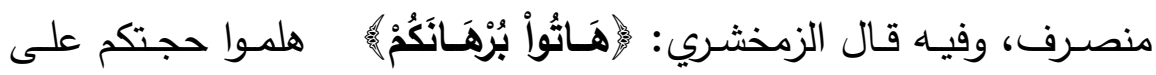
اختصاصكم بدخول الجنـة إن كنتم صـادقين في دعواكم، وهذا أهدم شيء لمذهب المقلدين. وأن كل قول لا دليل عليه فهو باطل غير ثابت و (هات) صوت بمنزلة هاء بمعنى (أحضر)"(r).

المعنى العام للآية:

يرى الطبري أن ظاهر الآيـة هو "ظاهر دعاء القائلين ـ دعوة اليهود

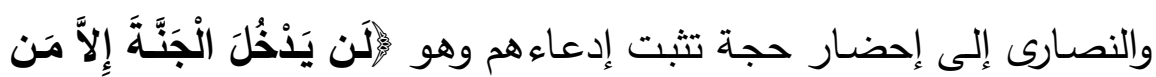

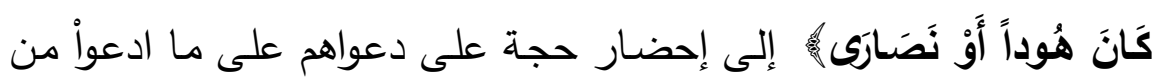
ذلك، فإنـه بمعنى تكذيب من الله لهم في دعواهم وقيلهم؛ لأنهح لم يكونواً قادرين على إحضار برهان على دعواهم تلك أبدًا"(r)، ولكن المعنى الضمني والمقصـود (التعجيـز) الخاضـع لسـلطة السـياق بعيدًا تمائـا عـن الصــورة الثكلية.

$$
\text { (1) (1) (1) (1) (1) (1) (1). }
$$

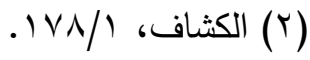

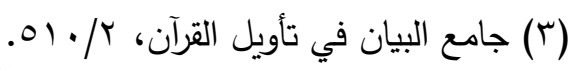




\section{الأفعال الكلامية في آيات التمجيز في القرآن الكريم دراسة تداولية}

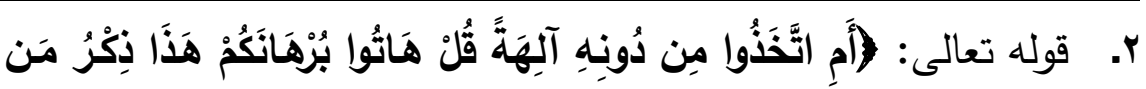

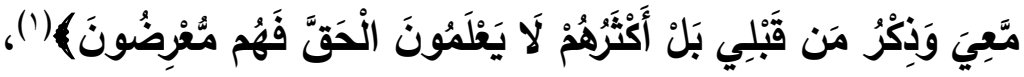

\section{المعنى العام للآيةه:}

"يقول تعـالى ذكره: أتخـذ هـؤلاء المشـركون مـن دون الله آلهـة تتفـع وتضر، وتخلَق وتحيي وتميت، قل يا محمد لهم: هاتواً برهانكم، يعني حجتكم

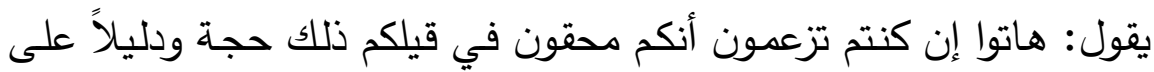

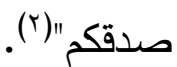

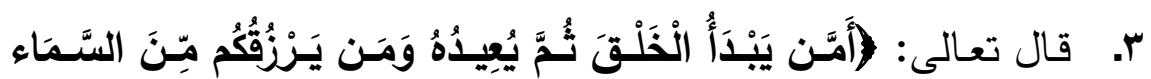

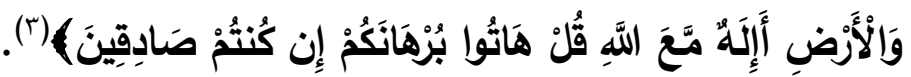

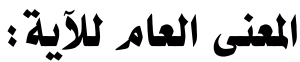

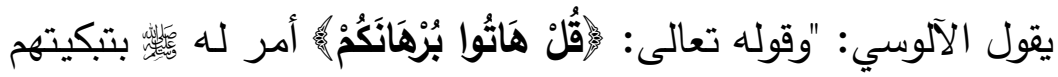

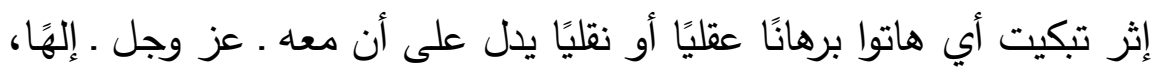
وقيل: أي هاتوا برهانًا على أن غيره . تعالى . يقدر على شيء مها ذكر من هن

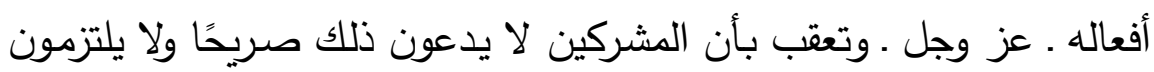
كونه دن لوازم الألوهية، وإن كان منها في الحقيقة فمطالبتهم بالبرهان عليه لا على صـريح دعواهم ممـا لا وجـه لله، وفي إضـافة البرهان إلى ضـيرهم تهكم بهم لما فيها من إبهام أن لهم برهانًا وأنى لهم ذلك؟ وقيل: إن الإضـافة

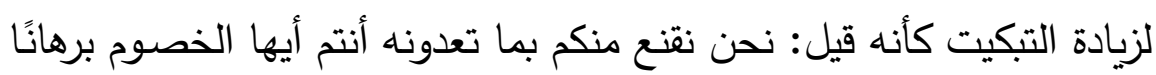

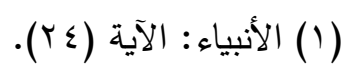

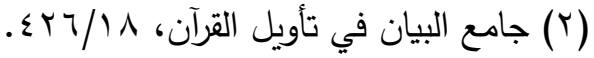

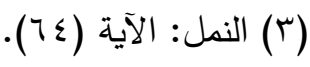


يدل على ذلك وإن لم نعده نحن ولا أحد من ذوي العقول كذلك، ومع هذا أنتم

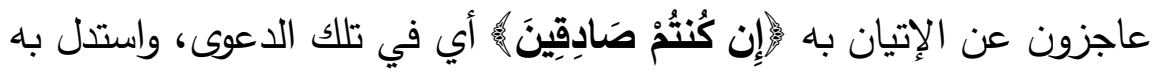
على أن الدعوى لا تقبل ما لم تنور بالبرهان" (').

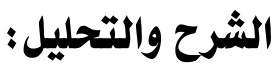

في هذه الآيـات أكثر مـن فعل كلامسي تأتي متتابعـة حسب تـوع

المقامـات، وكان "الإخبار في هذا عن أهل الكتاب"(؟)، فمقام الاستفهام في هي البدايـة مقتضـيًا لإيراد الخبر لنقل معلومـة، وإنجاز فعل كلامسي مباشر هو

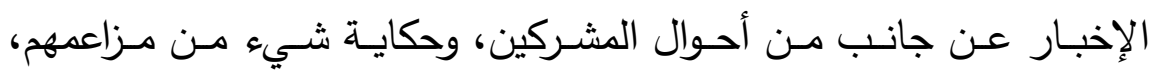
وإدعاءاتهم وأمنياتهم، ويتضمن الاستفهام فعلاً كلاميًا متضمنًا في القول وهو وحئ

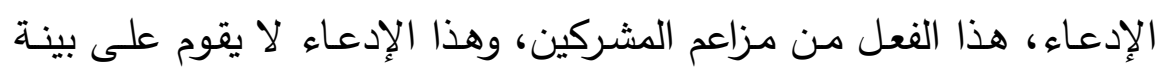
ويفتقر إلى دليل. والجملة الاعتراضية "قل هاتوا برهانكم"، "لا تكون إلا بين

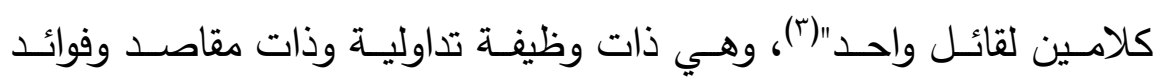
الاعتراض "تختلف بحسب قصد المتكلم وسياق الكلام"(£).

\section{الفعل الإنجازي المتضمن في القول:}

القصد هو إبطال دعوى المشركين السابقة، واقتضى كل من الإدعاء

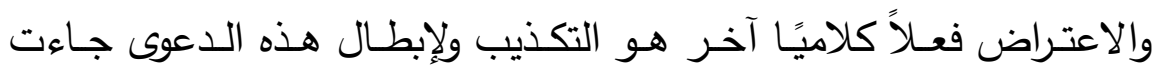
الجملة الأمريـة متكونـة من اسم فعل أمر (هات) وفاعل متصل ببنيته (واو هوعل

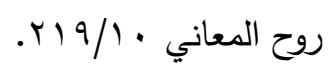

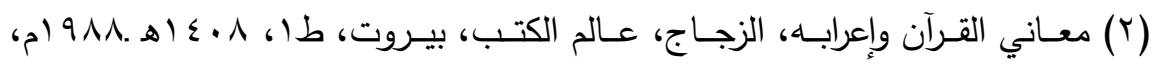
$.19 \leq / 1$

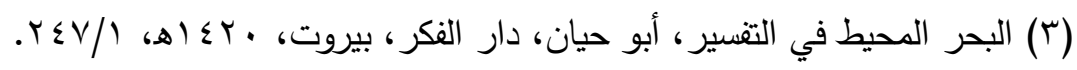

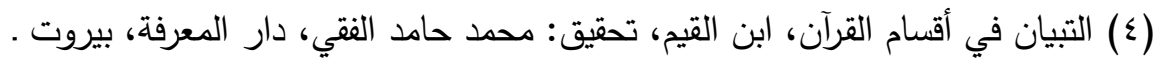




\section{الأفعال الكلامية في آيات التمجيز في القرآن الكريم دراسة تداولية}

الجماعة)، وهو المأمور، وفي الأمر دلالة التعجيز؛ لأن (هات) أتت للأكر مبالغة في الطلب، والجملة الأمريـة المكونـة من فعل الأمر والفاعل (هاتواً) تؤكد وجوب القيام بالفعل، وهذا أمر صريح في طلب البرهان على صحة وهل

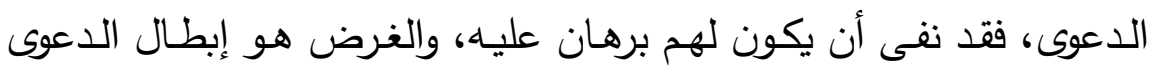

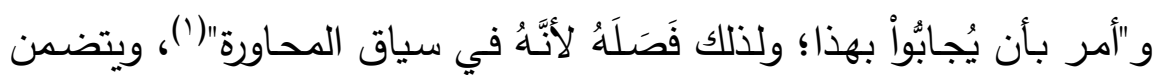
الأمر فعلاً كلاميًا غير مباشر وهو التعجيز ، وهو فعل مستلزم مقاميًا، وذلك لتخلف عنصر الإرادة لتخلف الإمكان. ففي دلالة التعجيز يتخلف الإمكان

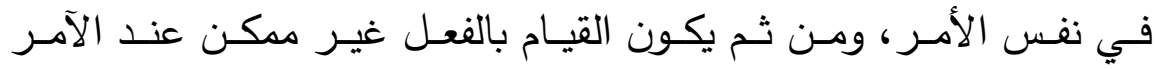
والمـأمور ... أمـا في دلالـة التحدي فيكون تخلف الإمكان من وجهـة نظر الآمر فحسب، بينما بزعم المأمور وهم المشركون يزعمون أن لهم قدرة عليه قولاً أو فعلاً بأن يسلك سلوك من يعتقد ذلك، كما في قوله تعالى : (هَاتُوا بُرْهَانَكَعُمْر).

وهكـذا يـراد بـالأمر التعجيـز والتحـدي لإبطـال دعـوى المشـركين، ويقتضي التعجيز فعلاً كلاميًا غير ظاهر هو التكذيب، وهذا الفعل الكلامي لإي مترتب على الذي قبله، ويراد بالتكذيب معنى الاستبعاد. وحسب تحليل (غرايس) يرجع السبب في هذه الآيـة إلى مبدأ (خرق قاعدة الكم)(؟)، فقد احتوت الآية على بعض المعلومات التي أدت إلى خروج

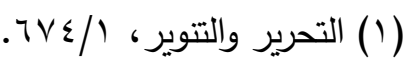

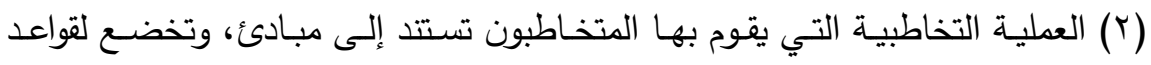
حوارية من بين هذه القواعد كما حددها غرايس:

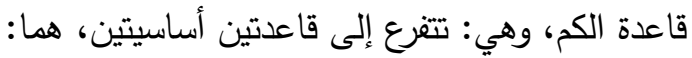

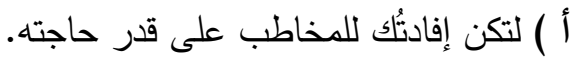
ب) لا تجعل إفادتك تتجاوز الحد المطلوب.

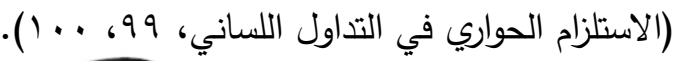


الأمر إلى معنى التعجيز، وتتمثل هذه القرينة اللغويـة في قوله تعالى: (إِن

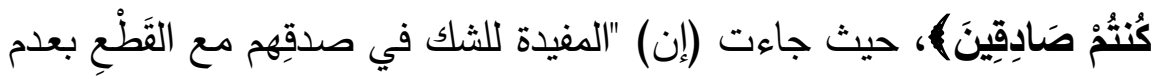

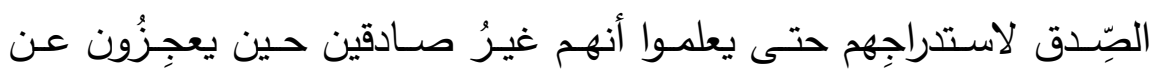

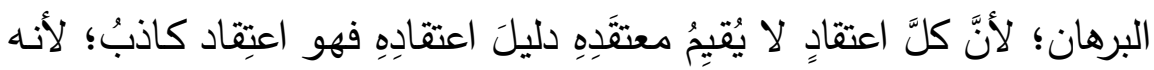
لو كان له دليلُ لاستطاعَ التعبير عنه" ('). ويمكن تلخيص ما سبق في الآتي:

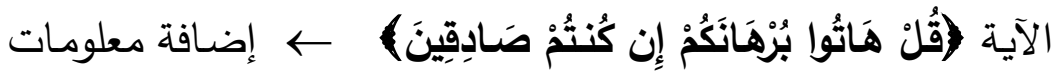
Ł خرق قاعدة الكم ـ خروج الأمر إلى معنى التعجيز •

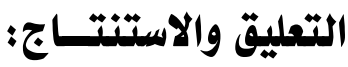

اشتملت هذه الآيات السابقة على صيغة من صيخ الأمر (اسم الفعل الأمر) يطلب بها على وجه التكليف والإلزام حصول شيء لم يكن حاصـلاً وقت الطلب، وبالتأمل في صيغتها رُؤى طالب الفعل فيها أعظم وأعلى ممن طُلب الفعل منه، وهذا هو الأمر الحقيقي. وعليه يمكن القول إن في استخدام الفعل (هاتوأ) توجيهًا تداوليًا من معنى الإنشاء إلى معنى التعجيز • ثانيًا ــ الفعل المضارع المقروذ بلامر الأمر بصيفة (لِتَفْعَلْ) : توطئة : ها هي ذا صورة أخرى تبرز بجـاء سعة اللغـة، واستيعابها للمعاني المختلفة باختلاف التعابير "ولاقتصار فعل الأمر على مقام المخاطب، احتيج

$$
\text { (1) (1) التحرير والتتوير ، (1) }
$$


إلى صيغة أخرى يتوصل بها إلى إفادة معنى الأمر ، في مقام الغيبة والتكلم،

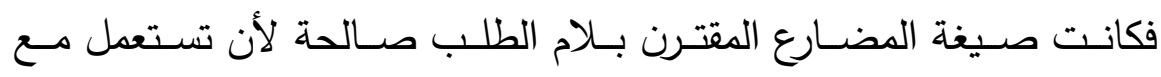

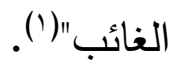

ويتم الأمر في هذا الجانب باللام، وهي التي تسمى بـ(لام) الأمر، أو

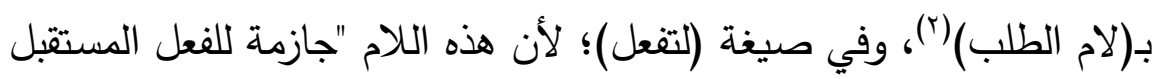

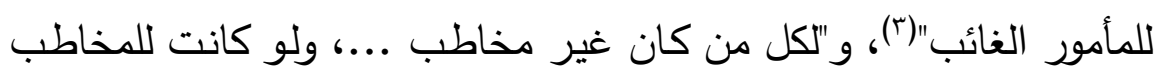
لكان جيدًا على الأصل"(\{)، والفرق بين بناء (افعل) وبناء (ليفعل) يكمن في:

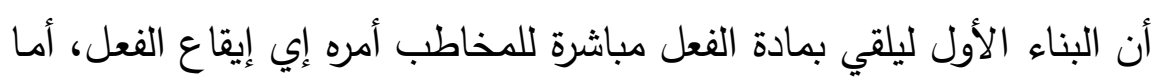
البناء الثاني، (لتقعل) أو (ليفعل) فإن دلالـة التجدد والحدوث يكون شئًا فشيئًا، أي التجزئة مـا تزال كامنـة في البناء، فإذا مـا دلّ على التلطف في الأمر، فإن في بناء (يفعل) ما يوحي بالتجزئة، وحدوث الحدث شيئًا فشيئًا، والأمر بهذا البناء أقرب إلى التلطف عن الأمر التام القاطع الذي يلقي دفعة واحدة مباشرة، وأمسا أن يدل بناء (لتفعل) على التشدد والقوة في الأمر ولام الطلب تدل على طلب الفعل على سبيل الاستعلاء فان (اللام) تحمل الدلالة على التوكيد، فيظهر التوكيد والثدة في الأمر بسببها(ه).

(1) مـن نحو المباني إلى نحو المعـاني (بحث في الجملـة وأركانها)، محمد طـاهر

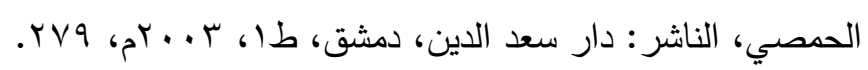

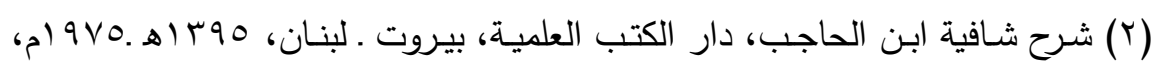

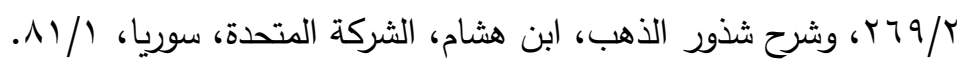

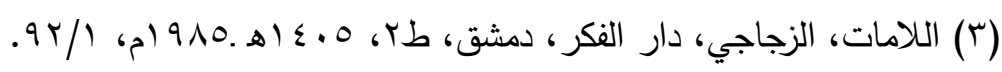

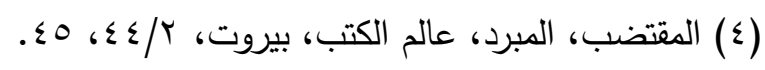

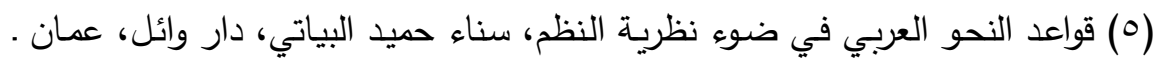

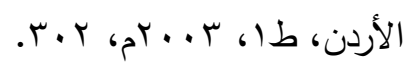


وقد يخرج الأمر بها إلى دلالة التعجيز تفهم من خلال السياق، ومن الآيات الدالة على ذلك:

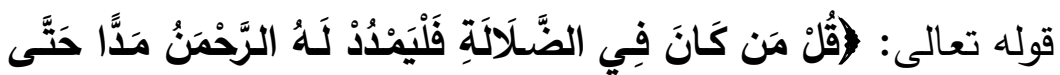

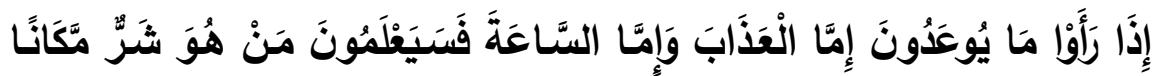

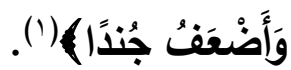

\section{المعنى العامر للآيةة: - المية}

"قل من كان في الضـلالة فليمدد لـه الرحمن مدا فيمده ويمهله العمر

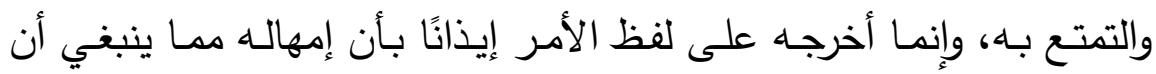

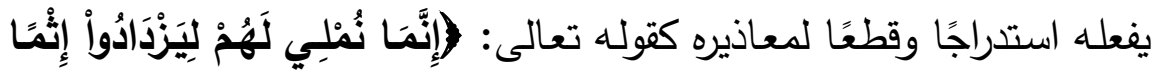

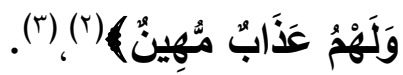

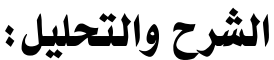

الناظر إلى هذه الآيـة قد لا يتبادر إلى ذهنه هذا المقصد؛ ذلك أن اللغة تشتمل على عدة كلمات، لا تقتصر دلالتها على معناها المتبادر إلى الذهن، وإنما تتجاوز ذلك المعنى (؛)، وهذا من بديع مقاصد القرآن في أساليب خطاباته، فأسلوب القرآن الكريم "يظهر بعض وحدات الكلام وعناصره بما

$$
\begin{aligned}
& \text { (1) مريم: الآية (Yo). }
\end{aligned}
$$

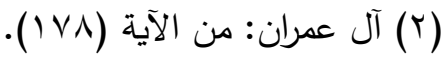

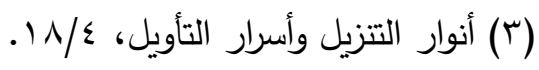

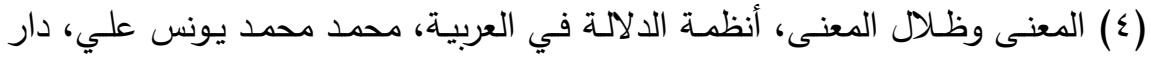

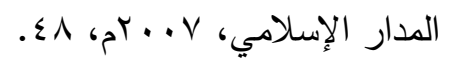


يحمل القـارئ على الانتبـاه إليها، وهذه الوحدات أو العناصـر لهـا دلالات

تميزية خاصة تجعل الانتباه إليها ضرورة والغفلة عنها تشويه للكلام"('). يقول الشوكاني: "هذا وإن كان على صيغة الأمر، فالمراد بـ الخبر ، وإنما خرج مخرج الأمر لبيان الإمهال منه ـ سبحانه ـ للعُصَاة، وأن ذلك كائن

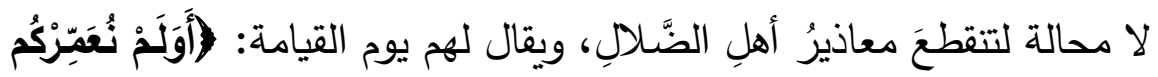

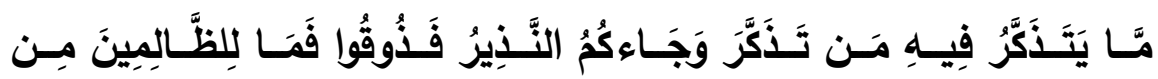

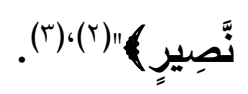

قال الزجاج: "هذا لفظ أمر في معنى الخبر ، وتأويله أن الله . عز وجل

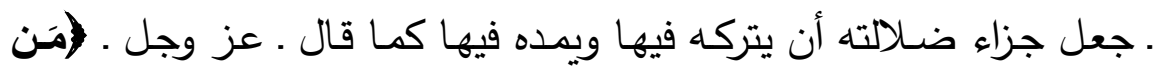

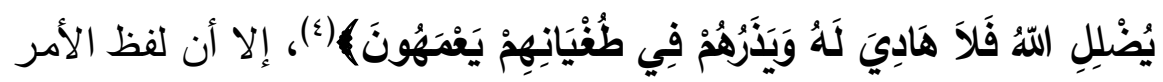

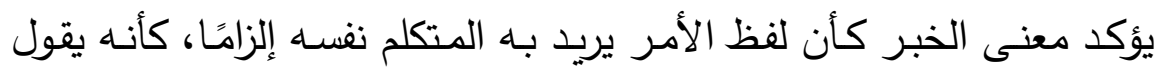

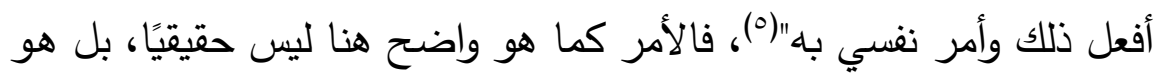
مجازي أفاد معنى الخبر، فأعطى معنى ثانيًا، وهو: التعجيز .

\section{الفعل الإنجازي المتضمن في القول:}

أسلوب الفعل الأمر (فليمدد) يظهر البعد التداولي؛ إذ هناك قصد غير مباشر في هذه الآية، وهذا القصد يكثفه المتلقي بإعمال الفكر، تستدعي إثارة العاطفة وذلك وفق القرائن والسياقات التي يُنتج فيها النص، وهذا الأمر بـر

(1) الأسلوبية والأسلوب، عبدالسلام المسدي، الدار العربية للكتاب، طرابلس، طس، س؟م.

$$
\begin{aligned}
& \text { (r) فاطر : من الآية (rV). }
\end{aligned}
$$

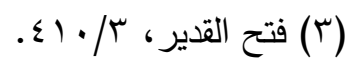

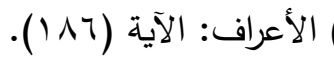

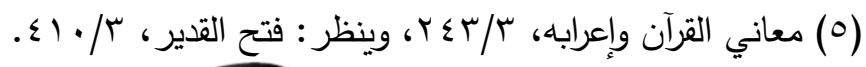


يلوح لنا مقصد غير ظاهر أو غير مباشر في قوله: (فليمدد) القصد منـه التعجيز ، جاء اللفظ بصـيغة لام الأمـر إيذانًا بوجـوب ذلك، ويحمل معنى الكى الخبر ؛ لأن الرحمن لا يأمر نفسه (1).

\section{تعليق واستنتـاج:}

الملاحظ في هذه الآية الكريمة أن الله ـ تعالى ـ يقول لبنيه ئس قل لهم

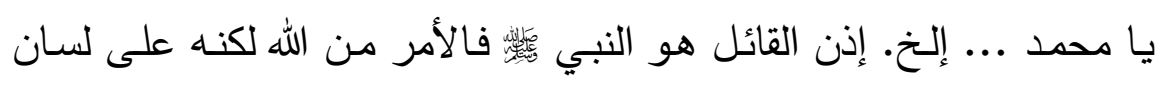
النبي ئلة وكأن الله يأمر نفسـه بأن يمد لهم، وهذا مبالغـة في تأكيد الإمهال لهج في الانيا، يقول الزمخشري: "فأخرج على لفظ الأمر إيذانًا بوجوب ذلك، لكان

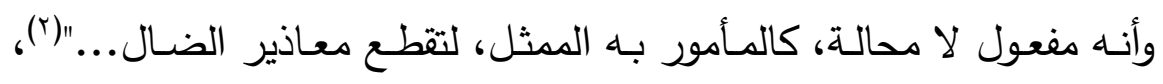
ويقول ابن عطية: "لام أمر دخلت في معنى الخبر ليكون أوكد وأقوى وهذا

موجود في كلام العرب وفصاحتها"(؟).

ثالثًا ـ الأمر المستفاد من معنى اللفظ والجملة: (الجملة الخبرية الدالة ءــلى

الطلب)

توطئة : - n

خاض علماؤنا الأوائل كثيرًا في مسألة تقسيم الكلام إلى خبر وإنشاء،

من أمثال: (السكاكي)، و(التفتازاني)، و(القزويني)، و(الجرجاني)، و(أبي

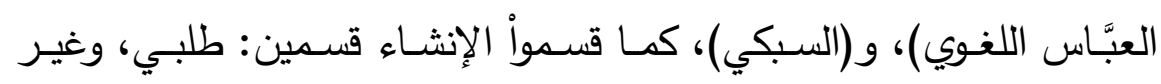

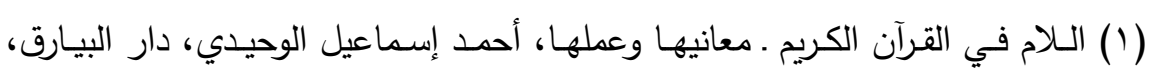

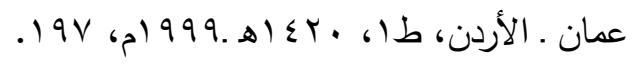

الكثاف،

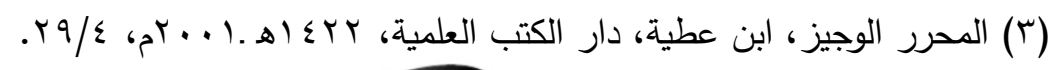




\section{الأفعال الكلامية في آيات التعجيز في القرآن الكريدر دراسة تداولية}

طلبي، ويُعدّ الأمر من الأسـاليب الإنشائية الطلبية التي تتردد على الألسن كثيرًا بصور مختلفة، غير أن البحث التداولي أكد مجيء الأمر خبرًا، ونشمّ الإِ عبق الفكرة في قول الخطيب القزويني: "ثم الخبر يقع موقع الإنشاء، إمـا للتفاؤل، أو لإظهار الحرص في وقوعده، والدعاء بصيغة الماضي من البليغ يحتمل الوجهين، أو للاحتراز عن صورة الأمر، كقول العبد للمولى إذا حَوَّل عنـه وجهها: ينظر المولى إليّ سـاعة، أو لحمل المخاطَب على المطلوب، بأن يكون المخاطب ممن لا يجيب أن يكََب الطَّالب أو لنحو ذلك"('). إذًا نستشـف مـن هـذا القـول تفطن الرّعيـل الأول مـن علمائنـا، إلىى إمكانية إنشاء أفعال من خـلال الجملة الخبريـة، بعدما أكدّ المهتمون بشؤون اللغة إنجاز الأفعال بأقوال إنشـائية، تستفاد من السياقات المختلفة، تتاولها أسلافنا باسم أغراض الكلام، في حين سمّاها المعاصرون بمتضمنات القول. وإذ أبحث في أسلوب الأمر القرآني لآيات التعجيز ، ألفيت عدد من الآيات في مختلف السور، تبرز ورود الأمر على شاكلة الخبر الحامل على إنجـاز فعل مـا، ومـن آيـات الذكر الحكيم الدالـة على الأمـر المتخذة شكل

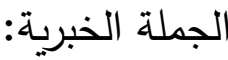

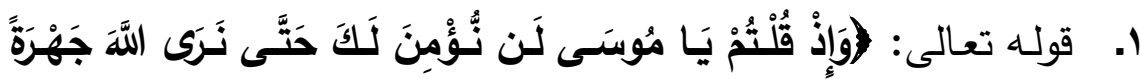

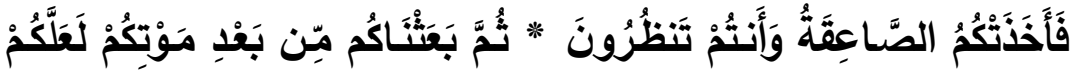

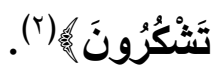

(1) الإيضاح في علوم البلاغة، القزويني، دار الكتب العلمية، 9. . بم، 0 ـ1.

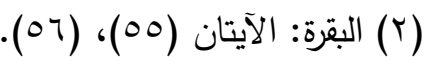


المعنى اللفوي:

جهرة: "جَهِر يقال لظهور الثيء بإفراطِ، أما بحاسة البصر فنحو رأيتُه

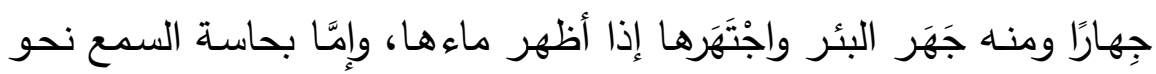

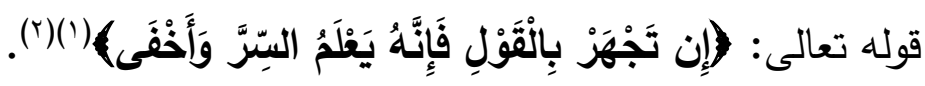

المعنى العام للآية:

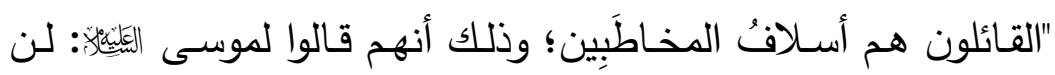

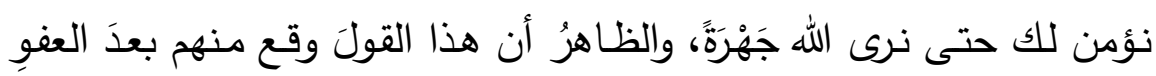

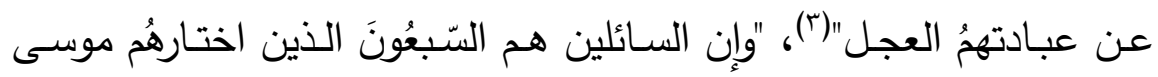

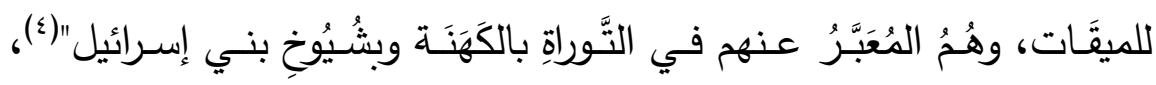

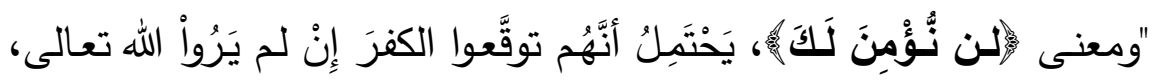

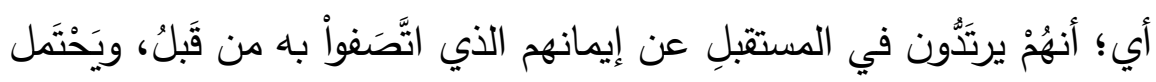

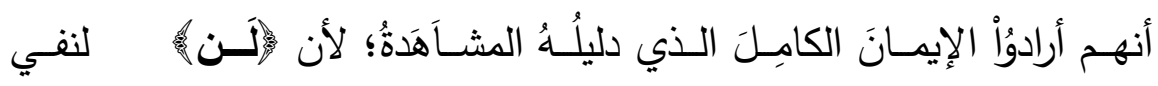

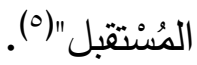

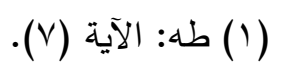

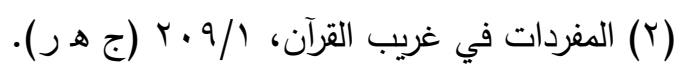

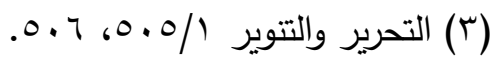

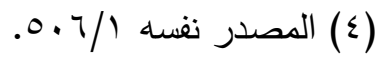

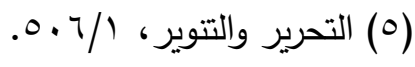




\section{الأفعال الكلامية في آيات التعجيز في القرآن الكريدر دراسة تداولية}

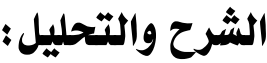

قال سيبويه: "لا لنفي يفعل، ولن لنفي سيفعل"()، وهذا التصرف الذي جاء من بني إسرائيل يدل على قلة اكتراثهم بما أوتوا من النّعم، وقلة اعتبارهم

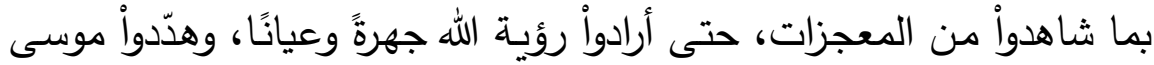

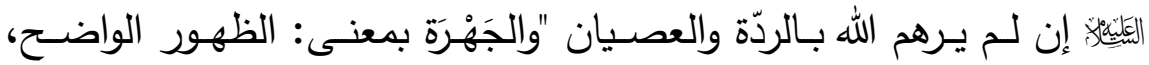
وانتصب (جهرة) على الهفعول المطلق لبيان نوع فعل (ترى)؛ لأن من الرؤية

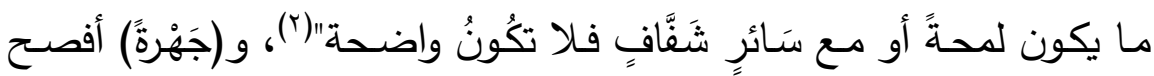

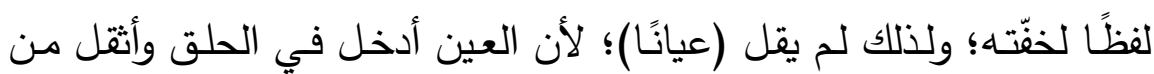
الجيم، وإيقاع الجيم المشربة والهاء والراء حَسَنُ على السّمحع، والقرآن الكريم قمّة في الفصاحة والبيان (r). يقول ابن كثير : "طلب الرؤية ليس لذاته، ولم يكونواً صـادقين فيه،

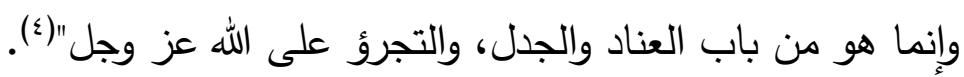

\section{الفعل الإنجازي المتضمن في القول : المي}

فعل القول (نرى) يتضـن معنى الأمـر أو الطلب مـن المشركين،

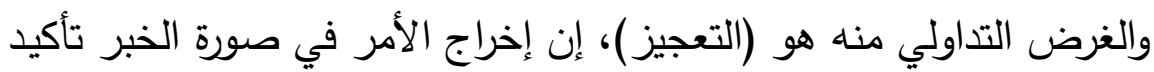

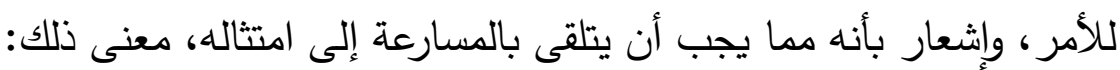

$$
\begin{aligned}
& \text { (1) الكتاب، 1/ 1. } \\
& \text { (Y) التحرير والتتوير ، V/ (Y) }
\end{aligned}
$$

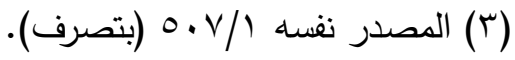

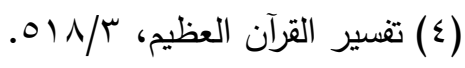


أن هذا التركيب لهو أوضـح مثال على أن شكل الصيغة التي أتي عليها غير كاف لإدراك المقصود، فقد جاء بصيغة الماضي لحمل المخاطب على هذا الفعل كأنه أصبح واقعًا (كما ذكر أوستين)، أو يمكن القول بأنـه هنا جاء بلفظ الخبر لكنها إنشاء عرفًا، ولعل قرينة الصيغة التي أتي عليها التركيب لها دور كبير في بيان مقصودية الأمر منه.

وملفوظ (نرى) يتضمن فعلاً إنجازيًا قوته الإنجازيـة كامنـة فيه والذي يدل عليه سياق الكـلام ومَا يستوجبه من الإلزام فالغرض التداولي هنا هو التعجيز

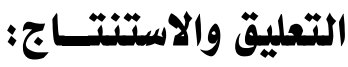

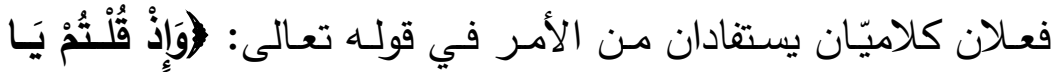

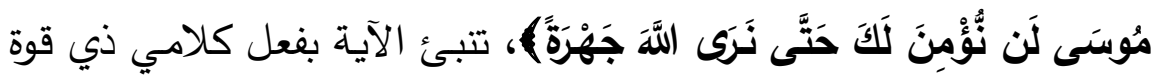

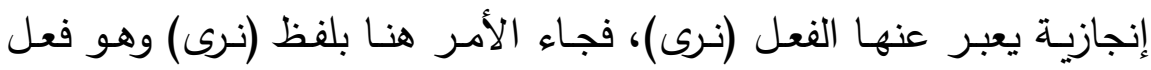
ماض يجعل من الجملة خبرية في ظاهرها، أمرية طلبية في مضمونها، وهو من الأوامر المدرجة في المواقف الحوارية، ضمن القصص القرآني.

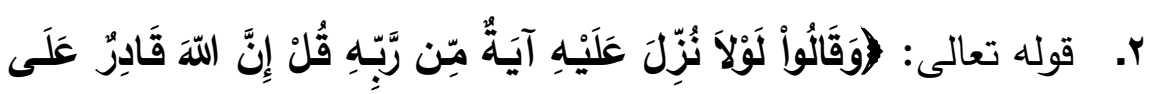

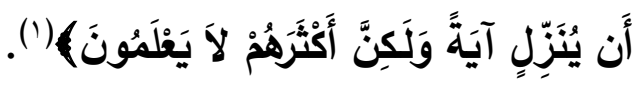


المعنى اللفوي: - nمي

"لولا: حرف تحضيض بمعنى (هَلَّ))، والتحضيض هنا لقطع الخصم

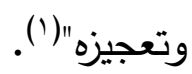

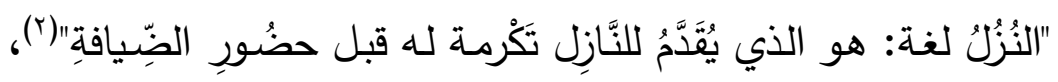

فجاءت الآية واستعملت بقصد مضاد لمعناها تمامًا.

\section{المعنى العام للآية : - المية}

تضمنت الآيـة بحسب النزول طلب المشركين من النبي

بالمعجزات الحسية المشاهدة، وكان هذا ـ كما قال الشيخ ابن عاشور ـ تعنتًا منهم بعد ظهور البراهين وإقامة الحجة بالقرآن الذين عجزواً أن يأتواُ بسورة

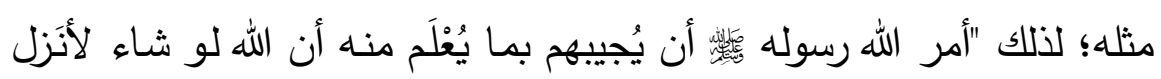
آية على وَفْق مقترَحهم تقوم عليهم بها الحجة في تصديق الرسول، ولكن الله

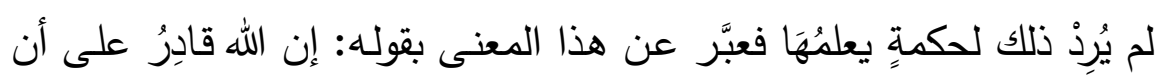
ينزِل آية وهم لا ينكرون أن الله قادر ؛ ولذلك سألواْ الآية"(").

\section{الشرح والتحليل: - (الشيل}

هذا القول منهم وبين أيديهم أفضل الآيات (القرآن الكريم) الذي كان

يتزل عليهم سورة سورة، وآية آية، يتلى عليهم حينًا بعد حين، تعين أن الآية

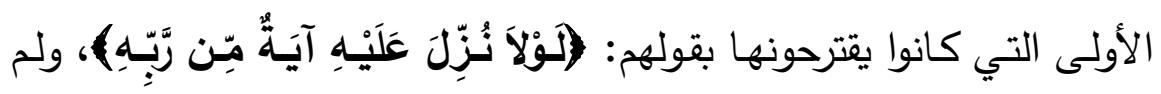

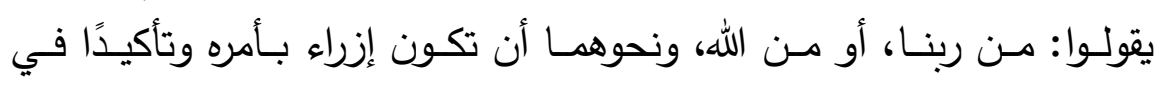

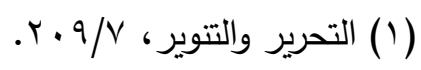

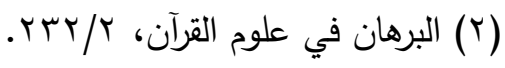

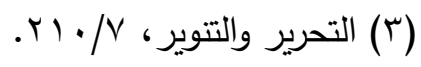


تعجيزه، أي لو كان ما يدعيه ويدعواً إليه حقًا فليغير له ربـه الذي يدعواً إليه ولينصره وليتززل عليه آية تدل على أحقية دعواه"('). فالجهـل بالمقـام الألـوهي هـو الذي بعـثهم إلى اقتراح الآيــة بـداعي التعجيز .. وذكر لفظ الجلالة (الله)؛ للإشارة إلى أنهم لا يوجهون الطلب إلى

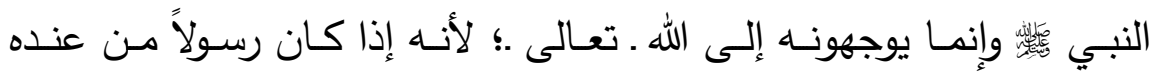
فليجب لـه هذا المطلب الذي نتمنـاه ونكون من بعده مؤمنين، فهم جعلواً

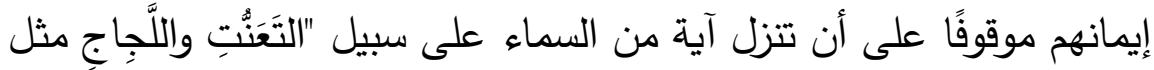
إنزالِ الملائكةِ وإسقاط السماء كسفَا وسائر ما حكَاهُ عن الكافِرِين"(؟).

\section{الفمل الإزجازي المتضمن في القول:}

فعـل القول (نـزل) يتضــن معنـى الأمـر أو الطلب مـن المشـركين، والغـرض التـداولي منــه هـو التعجيـز ، "إن اسـتعمال نـزّل قـد يكـون للتـدرج

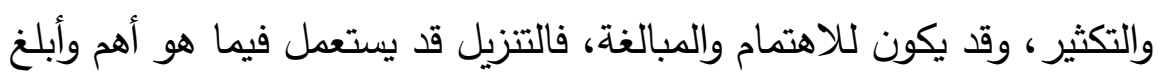

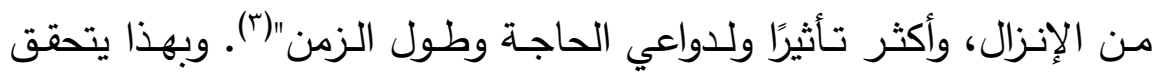

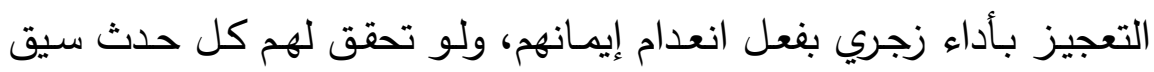
على وجه التحدي بتقابل متجسد في:

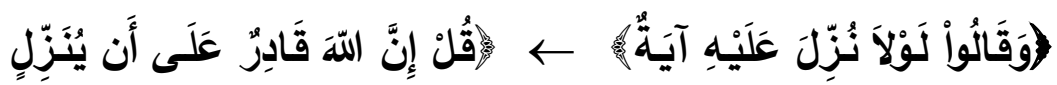

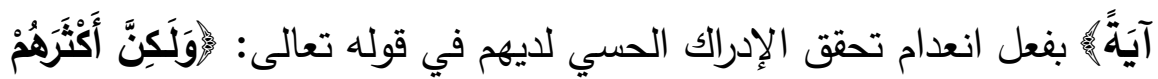

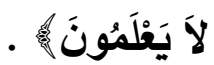

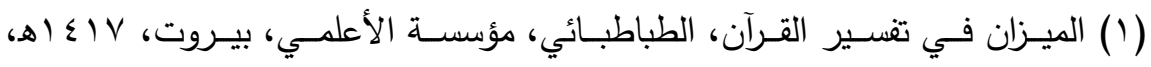

$$
\text { . } 70 / 1
$$

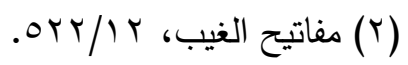

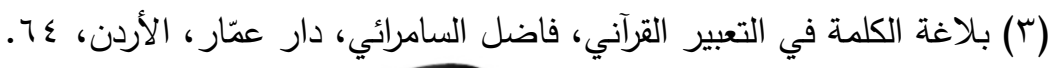


"إن المقدِّماتِ والنَّتِجـة تُدلُّ عَقْلاً على المطلُوبِ المستَدلِّ عليه، وإنَّ النتيجَةَ هي عَيْنُ المطلُوبِ في الواقِع، وإن كانت غيَرهُ في الاعتبَّار ؛ فلذلك

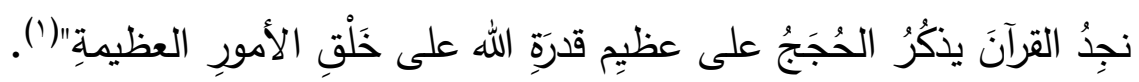

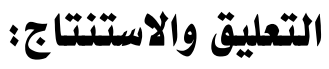

أ ) أعطت الآية الكريمة معنى التعجيز ، وجاء التعجيز مبدوءًا بـ(لو) متلوة بفعل، وجيء بـ(لو): "للبيان تحقيق مـا يفيده الكـلام السـابق مـ الحكم على كل حال مفروض من الأحوال المقارنـة لله على الإجمال بإدخالها على أبعدها منه وأثدها منافاة له ليظهر تحققه مع ما عداه من الأحوال بطريق الأولوية، أي: أتفعل فيّ ذلك حال عدم مجيء بشيء مبيء مبين وحال

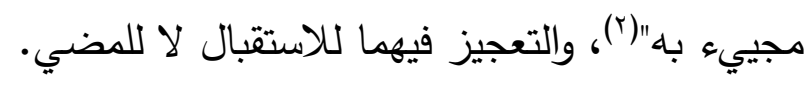
ب) جاء الفعل (نُزَّل) مبنيًا للمجهول جاريًا مـع سياق الآيـات متوافقًا على انتظـام السـياقات، وجـاء الفعـل (نُزل) بصـيغة الماضـي دون المضــارع

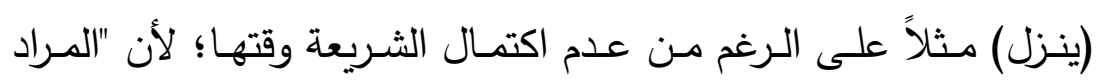
المنزل كله، وإنما عبر عنه بلفظ المضـي وإن كان بعضـاه مترقبًا، تغليبًا

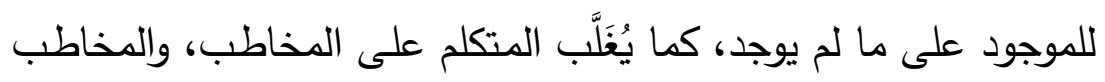
على الغائب، فيقال أنا وأنت فعلنا، كأن كله قد نزل وانتهى لنزوله، ويدل يله

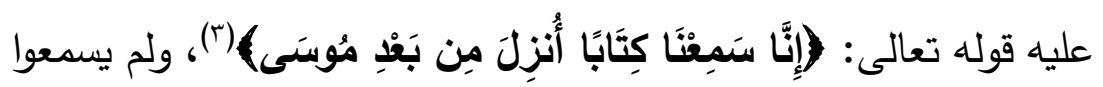

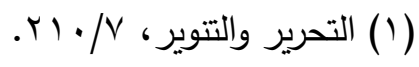

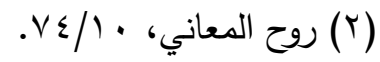

$$
\begin{aligned}
& \text { (r) الأحقاف: من الآية (·r) (ب). }
\end{aligned}
$$


جميع الكتاب، ولا كان كله نزولا"(')، وعبرواً بالإنزال دون الإعطاء؛ لأن

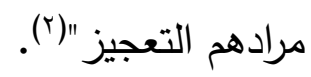

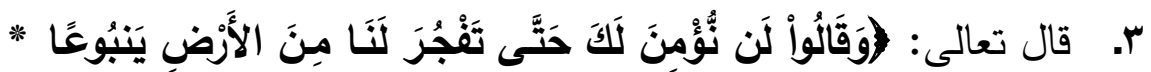

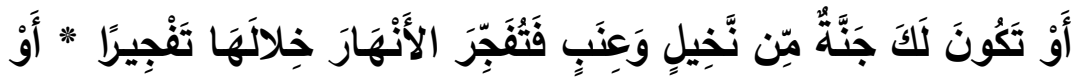

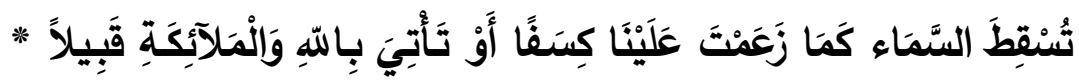

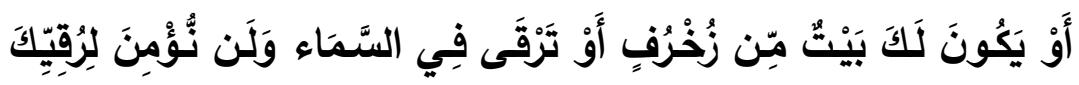

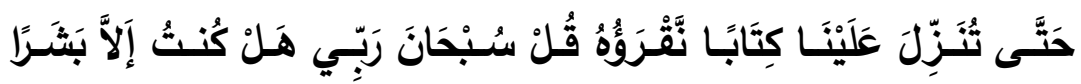

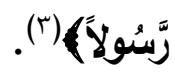

\section{المعنى العام للآيةه:}

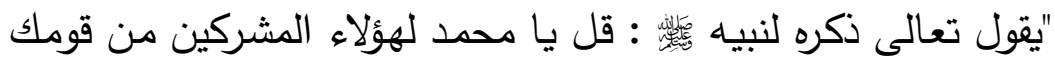
القائلين لك هذه الأقوال، تتزيهًا لله عما يصفونه به، وتعظيمًا له من أن يؤتي لئي

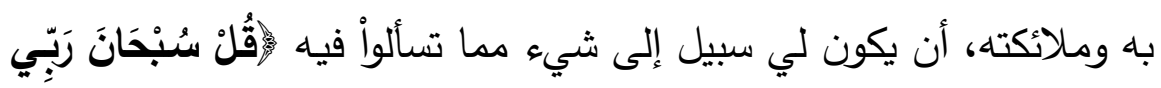

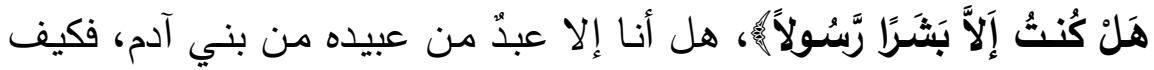

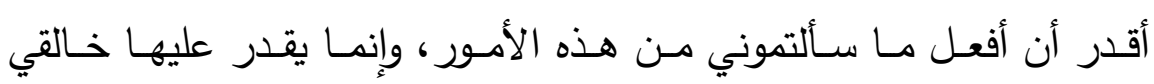

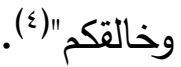

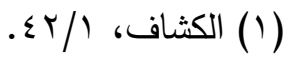

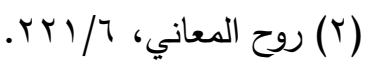

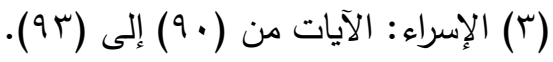

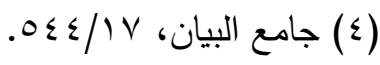




\section{الشرح والتح ليل : بليل}

يجسد الحوار في هذه الآيات مدى عناد ومكابرة المشركين من قريش، فهم يطلبون من الرسول يُّل أشياء لا يقبلها العقل مقابل إيمانهج بدعوة الدين

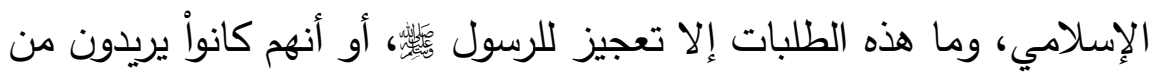
الرسول أل أن يكون مختلفًا من البشر ، ويتمتع بقدرات غير طبيعية تختلف

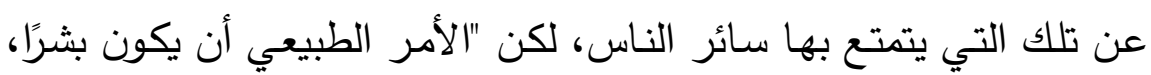

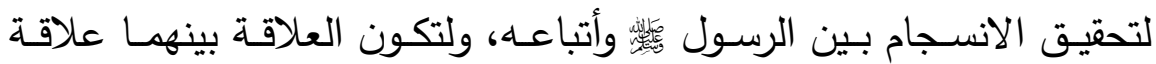
طبيعيـة؛ لأن مهمتهـ ليسـت البلاغ فحسب، بـل التجسيد الحي للفكرة في

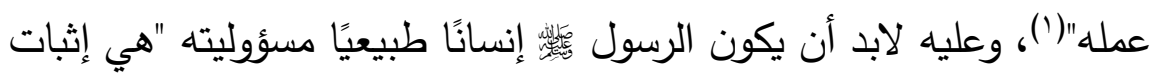

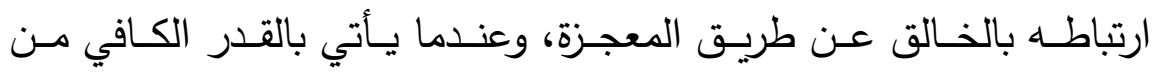
المعجزات، فليست عليه أية مسؤولية أخرى"(؟).

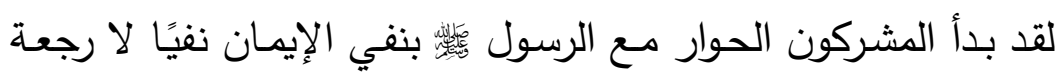
فيه، إلا بعد تنفيذ مطالبهم التي طلبوها، وكان الهدف من هذه الطلبات هو الاستمرار في دينهم، وعدم ترك عبادة الأوثان والأصنام التي كان يدعوا إلى ولى

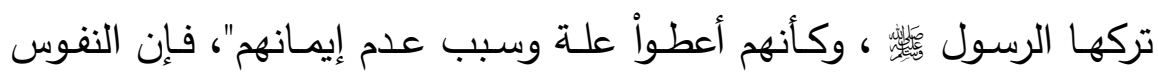

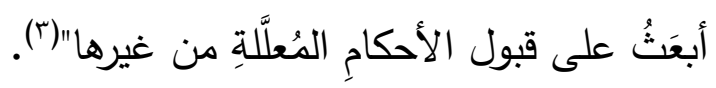

(1) الحوار في القرآن، محمد حسين فضل الله، دار الملاك للنشر ، لبنان، طه، V V إ اهـ (1) . 1 ro 1997.

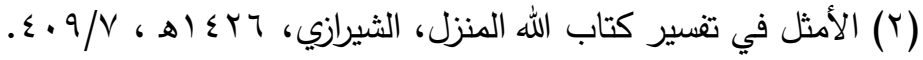

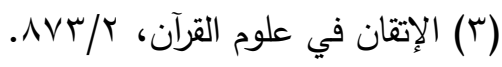




\section{الفعل الإنجازي المتضمن في القول :}

استخدم في هذه الآية أساليب فعلية متتوعة، منها:

1. طالعنا النص القرآني بمحور الفعل الكلامي في قولهه تعالى: (وقالوأ)، بوصفه إيمانًا مشروطًا يحقق أفعال مساقة على وجه الطلب في أحداث نسقية متعاقبة على وفق الآتي:

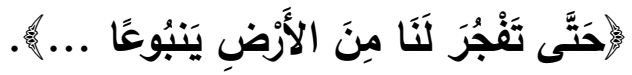

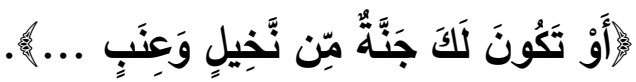

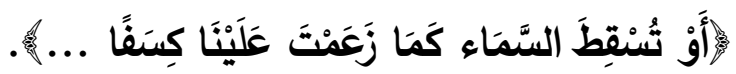

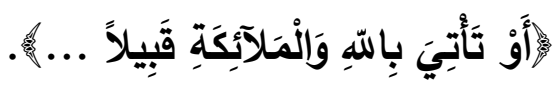

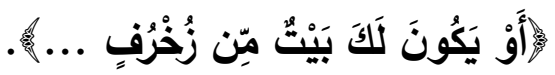
"كانوا يقترحون الآيـات فكان يَودُّ أن يجابواً إليها لتمادي حرصـه على

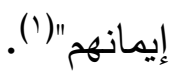
وعلى أسـاس توجيـه دلالــة المضـارع للإفـادة بـالأمر "جعـل كـل مـن (أوستين)، و(سيرل) المقاصد مركزًا في التفريق بين المعنى التعبيري

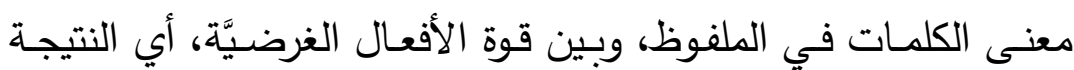
التي يقصد المتكلم نقلها [...]، وقد ركّز فلاسفة اللغة على الطرق التي يبحث عنهـا المـكلم لنقـل مقاصـده إلى المتلقِّي، وذلك بكل الوسـائل التعبيريَّة والغرضيَّة، ولكن بنفس القدر من الأهمية، يجب أن ندرك أن

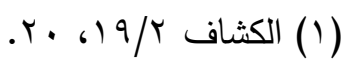


فهم مقاصد الآخرين، شيء مركزيّ لنجاح التخطيط في التفاعل"('). ويلاحظ من خـلال هذا القول: التركيز على مبدأ القصدية الذي ركَّز عليه التداوليون تحليلاتهم، وهم يسعون وراء إظهار علاقة التواصل بين المتكلم والمخاطب.

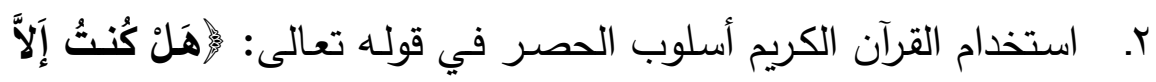

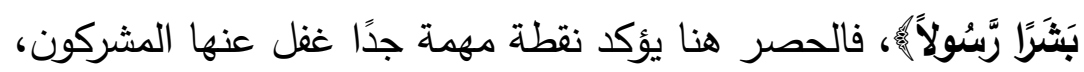

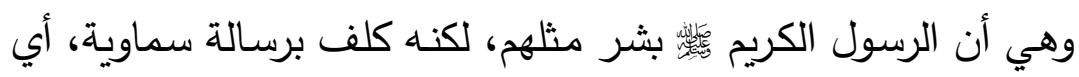

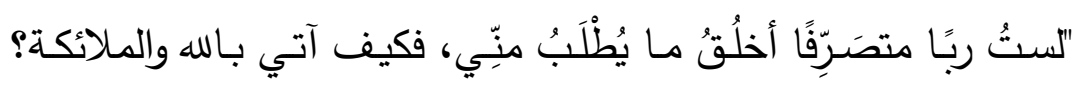

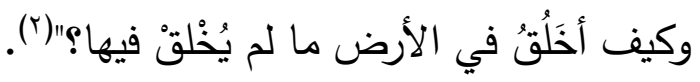

r. الاستفهام المسبوق بالتعجب في كلمة (سبحان) استفهام إنكاري توبيخي

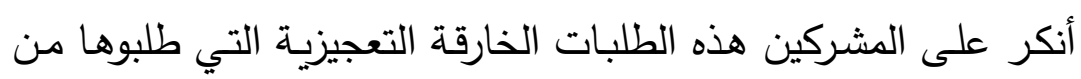

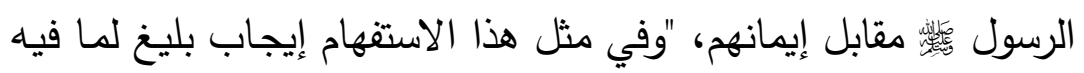
معنى الطلب والتتبيه على قيام الموجب وزوال العذر" "(". ع. استخدام المشركين بعض الألفاظ التي تدل على الموجودات الكونيـة التي أشارت إليها الآيات السابقة، فقد ذكرت الأرض والسماء والينبوع والجنــة والنخيـل والعنـب والأنهـار والملائكـة والبيــت والزخـرف، وهـذهـ

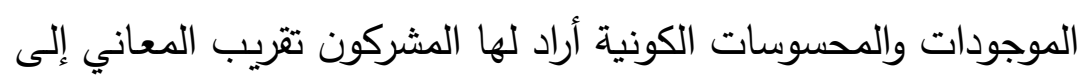
المخاطب بأن هذه الطلبات ما هي إلا تعجيز للرسول

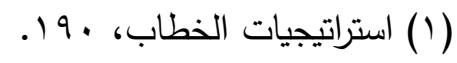

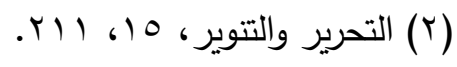
(r) حاشية محي الدين شيخ زاده على تقسير القاضي البيضـاوي، محي الدين شيخ زاده،

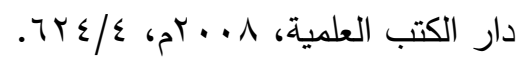


๑. استخدام التوكيد بالمفعول المطلق؛ "لأن إدخال المفعول المطلق على هذه الأفعال يجعل للأفعال فيها مقتضيات فات أوان نفيها أو الاعتراض لاض التون عليها، فقد جاء المفعول المطلق يفي المقتضى من هذه الأفعال إمكان أن يُنْني أو يدحض أو يعترض فئ" (1).

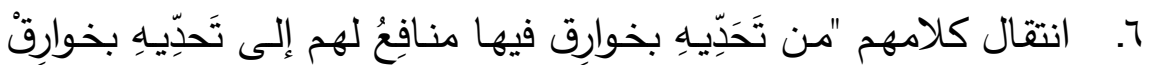

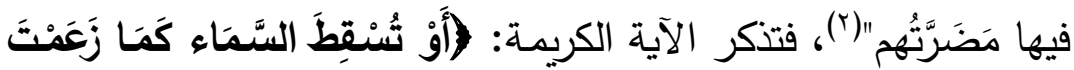

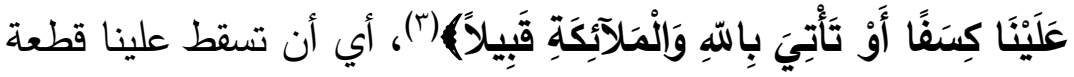
من القطع الموجودة من السماء "وتبدو طفولـة الإدرالك والتصسور، كمـا يبـدوا التعنـت في هـذه المقترحسات السـاذجة وهــ يسـون بـين البيــت المزخـرف والعـروج إلى الســاء!، أو بـين تفجيـر الينبـوع مـن الأرض ومجيء الله ـ سبحانه ـ والملائكة قبيلا!، والذي يجمع في تصورهم بين هذه المقترحات كلها هو أنها خوارق، فإذا جاءهم بها نظرواً في الإيمان له والتصديق به"(£).

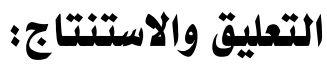
يظهر مما سبق ما يأتي:

I. بما أن هذه الطلبات كلها خوارق، والخوارق ليست من عمل الرسول بل هي تقدير وصنع الله ـ سبحانه وتعالى ـ متى ما قدر لها يفعلها، وقد

(1) الحجـاج في القرآن من خـلال خصائصسـ الأسلوبية، عبدالله صـولة، دار الفـارابي،

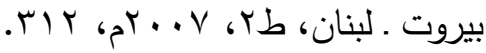

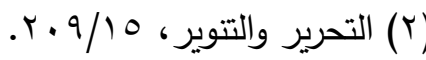

$$
\begin{aligned}
& \text { (r) الإسراء: الآية (r) (1). }
\end{aligned}
$$

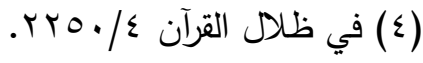




\section{الأفعال الكلامية في آيات التعجيز في القرآن الكريدر دراسة تداولية}

تبين مدى عناد المشركين، وأنهم أرادواً بهذه الطلبات نفي الإعجاز عن رسول الله

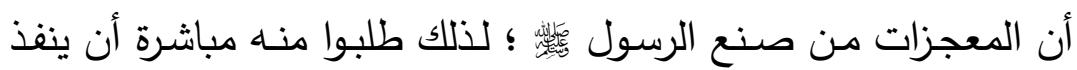
لهم هذه المطالب، ولم يقولواً ادع لنا ربك أن يفعل كذا، وكذا؛ لذا جاء

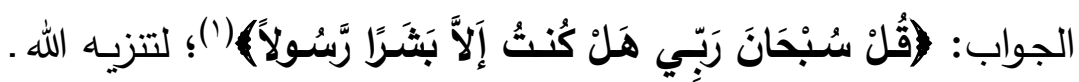
سبحانه وتعالى ـ أولاً، ثم إزالة كل هذه المعتقدات والأوهام من عقولهم "ويثبت لهم بأنه ليس هو الله ولا هو شريكه، والمعجز من الله . سبحانه وتعالى ـ دون سواه، فأنا بشر مثلكم"(؟).

r. تدرجت تلك الأحداث على وفق أداء تصاعدي غير ممكن التحقق؛ إذ استهلت بتفجير العيون بعدها تكوّن الجنـان بعدها يقـع التحدي في طلبهم في سقوط كسف من السماء، ثم تحدي رابع ثم العودة إلى الحسّ

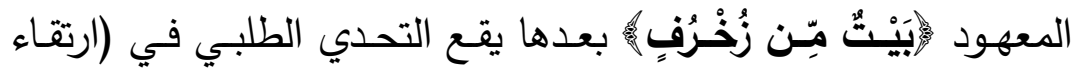
السماء)، وكل تلك الأحداث غير متحققة في نفوس المعاندين بفعل يقينهم التام من انعدام تحققها، وإن تحقتت فلا يتحقق معه إيمانهم بفعل

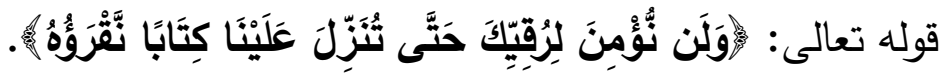
r. تلك الأحداث تُعدّ الأصل المعيشي بالحس المدرك بالفناء على وفق ما عُرض من تسلسل منطقي؛ لإثبات القدرة الإلهية المقدسة. 
تعقيب عام على هذا المبحث:

من خلال ما سبق، تبين:

ا. "أن الأمر استراتيجية من استراتيجيات اللفظ التي يستعملها المتكلم قصد تهيئة المتلقي، أو لفت انتباهه، أو تتبيهه واستمالته، وقد ورد هذا الفعل كثيرًا في آيات التعجيز في القرآن الكريم، مما يدلل على مراعاة القرآن

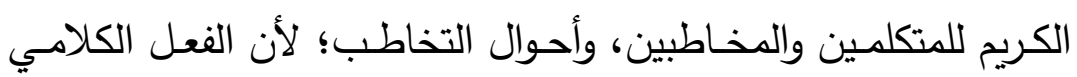
"ينظر إلى عملية التخاطب بمدى اكتشاف المتلقي للموقف المعبر عنـه خلافهم قصد المتكلم"('). فالمتلقي لا يصل إلى قصد المتكلم إلا بعمية ذهنية استدلالية، وبمعونة السياق وأحواله، وقرائنه. r. جاء الأمر التعجيزي المستحيل التتفيذ أمر تخلف فيه عنصر مهم من عناصر إتيان الأمر على حقيقته، وهو عنصر (إمكان الحصول)، مما

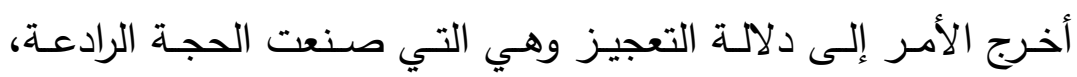
فالتعجيز دال على شدة العقوبـة، ولقوة الحجـاج بنيـة الأمـر التعجيزي اكتفى بـه حجة وحيدة في الأمر ذاته في مقامات آخر ، كان الخطاب فيه عامًا موجهًا إلى المتلقي الكوني. r. امتدت سلسـلة الأفعـال الكلاميـة الأمريـة (مباشـرة وغيـر مباشـرة) في كي الآيات القرآنية السـابقة، فكان مسـار القوة الإنجازيـة يتضـاعف مع كل فعل كلامي لاحق، وكانت القوة الآمرة تعلو بتتابع البنيات التركيبية، فالأمر الموجه مباشرة بأفعال الأمر أكثر شدة من الأمر الضمني واسم

(1) مقدمة في علمي الدلالة والتخاطب، محمد محمد يونس علي، دار الكتاب الجديد

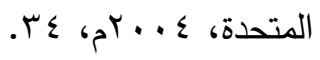




\section{الأفعال الكلامية في آيات التعجيز في القرآن الكريدر دراسة تداولية}

فعل الأمر (هاتو) دلالته أشد وأقوى من فعل الأمر الصريح، فتظهر الأفعال الكلامية بالتدرج من الأدنى قوة إلى الأشد قوة.

ع. هذه الأفعال تؤثر في المخاطب بشرط معرفته السياق التواصلي، فإن فات المخاطب معرفة هذا السياق فات الأثر ، الذي تُحدثه هذه الأفعال

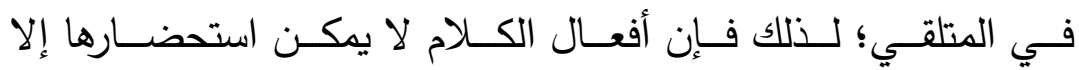
باستحضار الشروط التداولية، ومقتضيات المقام والحال؛ لأنه لا يكفي أن يتلفظ بالفعل ليحصل بذلك ما يترتب عليه؛ بل قد يعرض أن يتلفظ بالفعل، ومن ثم لا يوجد لله أثر في الخارج، ومن ثم يشترط في إنجاز التلفُظ بالعبارة أن تكون مطابقة لمقتضى الحال (1).

(1) نظرية أفعال الكلام العامة، أوستين، YV، وينظر : مدخل إلى علم النص ـ مشكلات

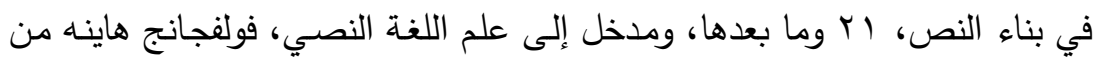

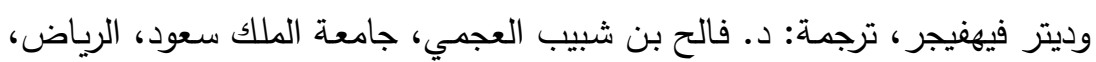
ط1، 


\section{المبحث الثالث}

\section{الأثر التداولي لأففال الكلاه في أسلوب الاستفهاه}

توطئهة:

لقد اهتدى (سيرل) إلى أنواع أخرى من الأفعال الكلامية، ميزتها أن دلالاتها الفعلية لا تظهر صريحة في عبارة المتكلم، إنما تأويل هذه الدلالة وفهمها يحتاج إلى العودة لعوامل السياق المحيطة بالمتخاطبين، وهو الأمر الـي جعـل المخاطب يـؤول اسـتفهام المخاطب على أنـه طلب، أو لنقـل استفهامًا طلبيًا.

والاستقهام مصدر الفعل (استفهم)، "واستفَهَمهُ": سـأَلَهُ أن يُفَهِهَهَه، وقد

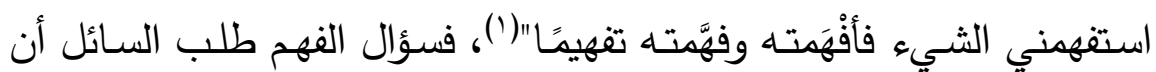
يخبره المسؤول عمَّا يسـأل؛ ولذلك سـاوى ابن فـارس بين معنى الاستقهام والاستخبار ، فقال: "الاستخبار : طلب خُبْر مـا ليس عن المستخبر ، وهو

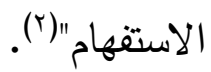

هذه الدلالة اللغوية انطلق منها بلاغيونا القدامى في تقسيم الاستفهام إلى حقيقي ومجازي أو بلاغي، والحقيقي: ما طلب بـه السائل أن يعلم مـا ليس عنده علم به، والمجازي: ما انحرف من هذه الدلالة إلى دلالات أخر أو بأ معانٍ أخرٍ حسب الموقف والسياق وقرائن الأحوال.

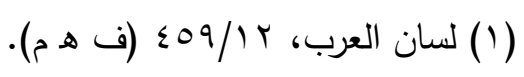

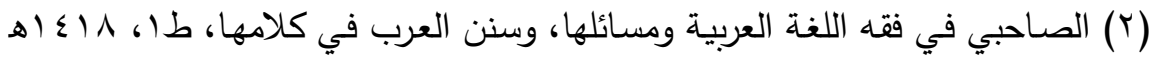

$$
\text { . }
$$


ولأسلوب الاستفهام أثرُ طيبٌ في آيات التعجيز في القرآن الكريم، كما

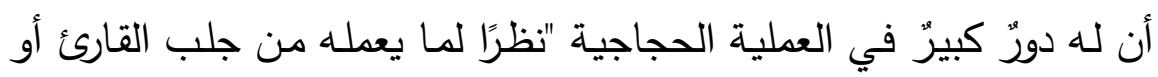
المسـتمع في عمليـة الاسـتـلال، بحيـث إنـا يثـركه بحكم قـوة الاسـتفهام

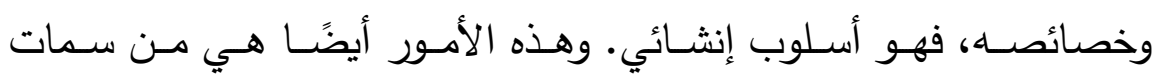
الاستفهام البلاغي في القرآن الكريم، بحيث إنـهـ يخدم مقاصــ الخطـاب،

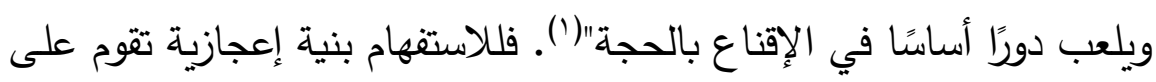
طرح القضية المخصوصة، ثم تقديم ما يشرحها ويعلّلها.

وقد وُظِّف الاستفهام في آيات التعجيز حول قضية تتحصور حولها الآيـات، وهي قضية (الأفعال الكلاميـة)، فهي تقتضـي البيان وقرع الحجَّة

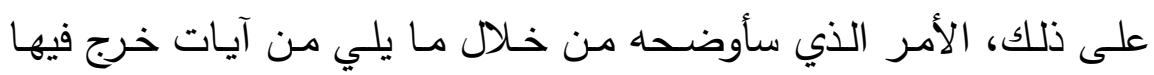
الاستفهام عن معنـاه الحقيقي إلى معنى التعجيز نتوصـل إليـه مـن خـلال

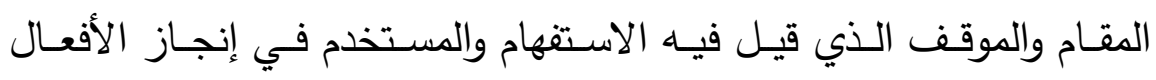

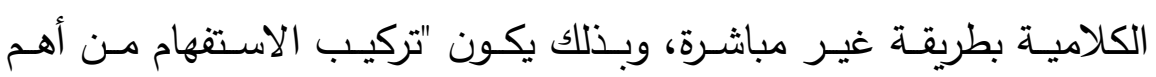
التراكيب التي اعتمدها القرآن الكريم في المجادلة، لما لهذا الأسلوب من قدرة على حمل المجادل على التفكير والتأمل؛ ليدخل دائرة الاقتناع، ويسير على فلى خطى الحقيقة، فيصل إلى القناعة الذاتية"(؟). ولعل من أهم الآيات الاستفهامية التي أعطت دلالة التعجيز من خلال عدد من السياقات التي وردت فيها:

(1) البنية الحجاجية في القرآن الكريم، (سورة النمل نموذجًا)، الحواس مسعودي، مجلة

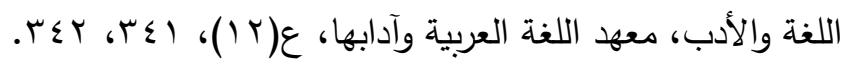

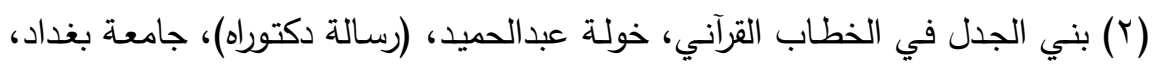
كلية التربية للبنات، 7 . . بام، 110. 


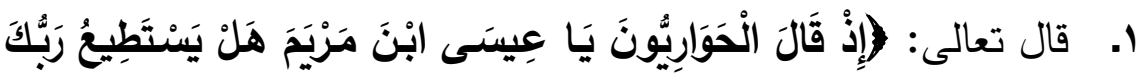

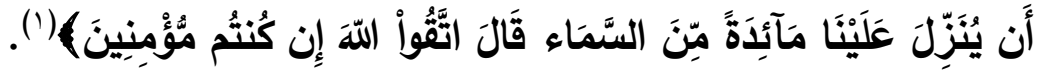

\section{المعنى العام للآيةه:}

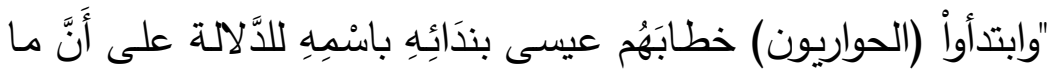

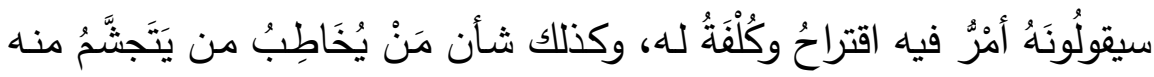

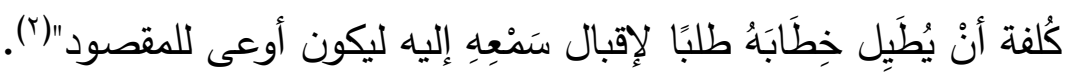
الشرح والتحليل: - | (الشيل

يرى ابن عاشور أن في هذا الاستفهام تأدبًا ولطفًا، إذ يقول: "وجرى

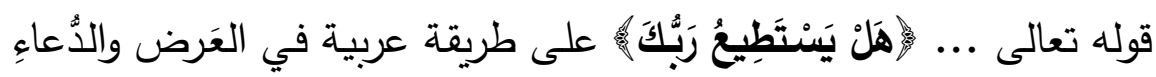

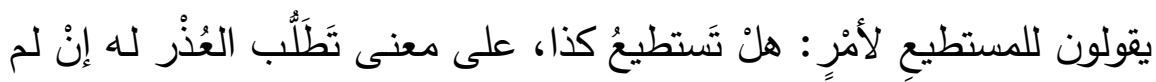

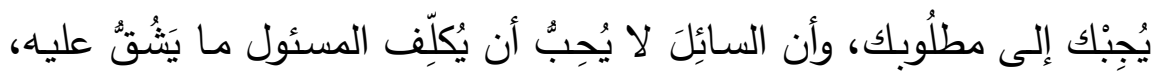

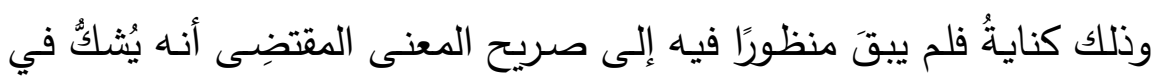
استطاعة المسئول، وإنما يقول ذلك الأدنَى للأعلى منه، وفي شيء يعلمُ أنهـ

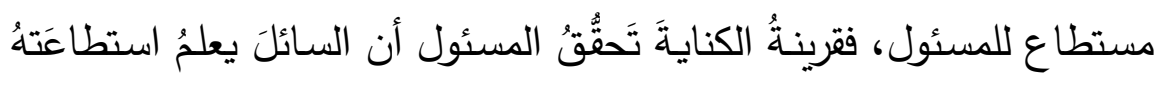
.... فليس قولُ الحواريِّن المحكِيُ بهذا التَّفظِ في القرآن إلا لفظًا من لغتِهِ يدلُّ على التَلَطُف والتأدُّب في السُؤال، كما هو مناسِبُ أهل الإيمان الخَالَص

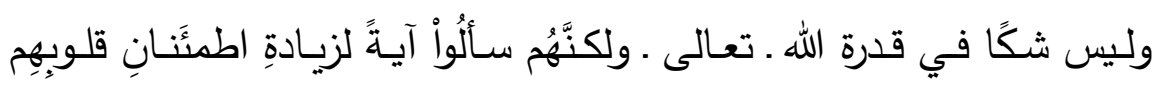

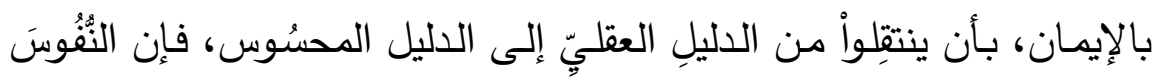

$$
\begin{aligned}
& \text { (1) المائدة: الآية (Y) (I) (Y). }
\end{aligned}
$$

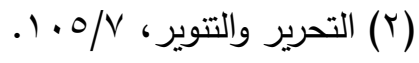




\section{الأفعال الكلامية في آيات التعجيز في القرآن الكريمدراسة تداولية}

بالمحسُوسِ آنسُ"(')، وهذا وجـه من عدة وجوه في رفع الثك في اقتدار الله

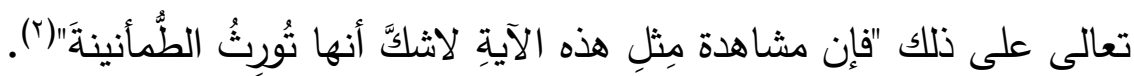

\section{الفعل الإنجازي المتضمن في القول:}

جاء في هذه الآية الفعل الإنجازي غير مباشر (الاستفهام بوصفه فعلاً

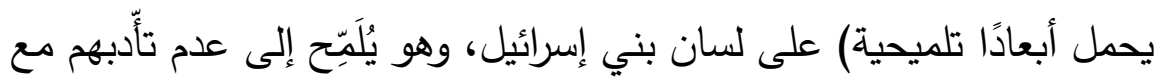

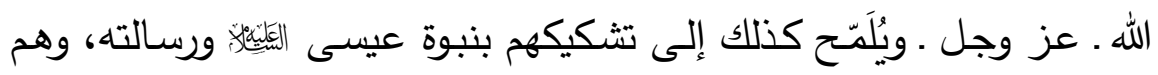

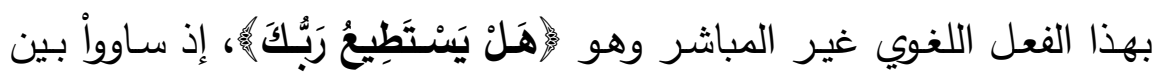
الخالق والمخلوقين، فـ(هل يستطيع) فعل لغوي غير مباشـر يستعمل بين متخاطبين من نفس المستوى، أي بين البشر، وليس بين الخالق والمخلوق،

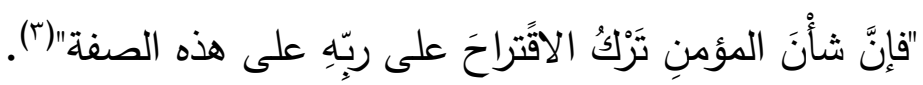
وتتمثل القوة الإنجازيـة المباشرة لهذه الآيـة القرآنية في الاستفهام في

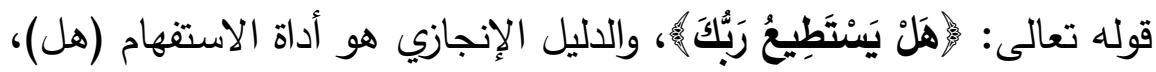
وأما القوة الإنجازية غير المباشرة المتضمنة في القول هي التعجيز.

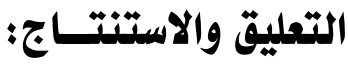

بناءً على ما سبق من تحليل لأسلوب الاستفهام في هذه الآية يتبين أن: استكاره ـ سبحانه ـ لعدم تأدبهم فيه تلميح إلى أنهم على معرفة بحقيقة

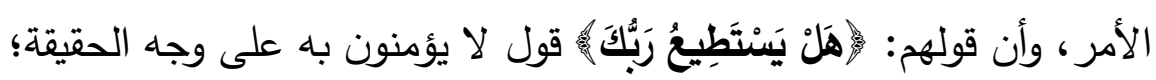

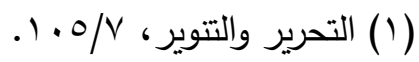

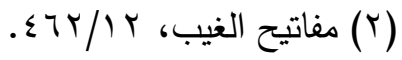

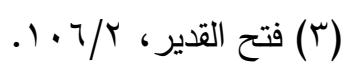


لأن المقـام مقـام إنكـار وليس مقـام دعـوة، وهذا تلمـيح بـديع؛ لأنــه يستلزم عصيانًا دعائمه الكبر والعناد وقوته الإنجازية هي التعجيز •

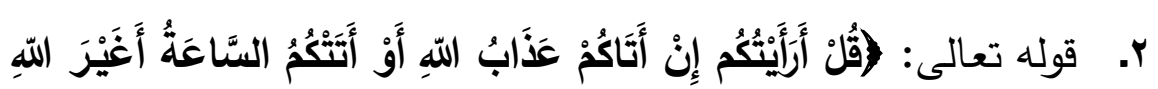

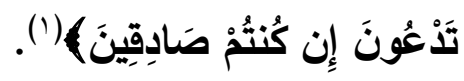

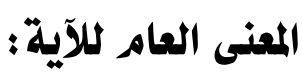

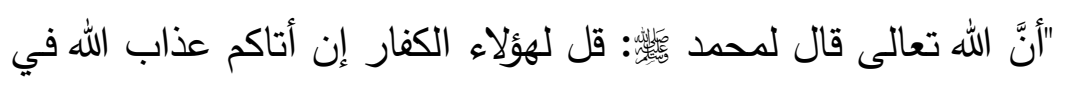
الدنيا وأتاكم العذابُ عند قيامٍ السـاعَةِ، أَتَرجِعونَ إلى غير الله في دفع ذلك

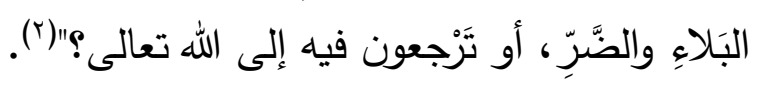

الشرح والتحليل:

جاءت الآية القرآنية متضمنة تعجيز أحداث يكون وقوعها حاصلاً في المستقبل لا محالة، فقد جاءت الآية مؤكدة للكفار إتيان العذاب لهم، إما في الحياة الدنيا وإما الآخرة، ومعلوم أن العذاب واقع بهم إما في الدنيا وإما في

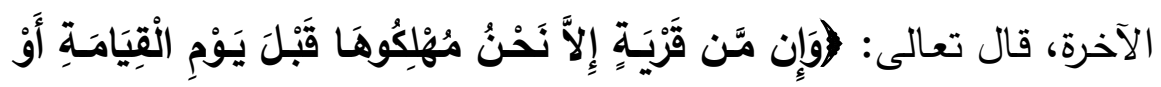

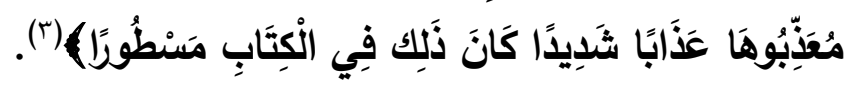

فالآيـة الكريمـة "احتجـاج على المشـركين، وإقامـة حجـة على بطـلان شركهم من وجه، وهو أنها تفرض عذابًا آتيًا من جانب الله أو إتيان الساعة إليهم، ثم تفرض أنهم يدعون في ذلك من يكثف العذاب عنهم على ما هو التهاب

$$
\begin{aligned}
& \text { (1) الأنعام: الآية (••). }
\end{aligned}
$$

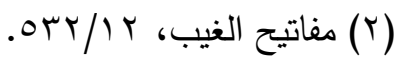

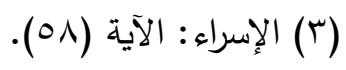


المغروز في فطرة الإنسـان أن يتوجه بالمسألة إذا بلغت بـه الثدة نحو من يقدر أن يكثف عنه"(').

ومعنى قوله تعالى: (أََأَيْتَكُم) ): أخبروني، والضمير الثاني (الكاف) لا محل لله من الإعراب(ז)، ويبدو أن في المعنى قلبًا للضمير المخاطب إلى ولى ضمير المتكلم الذي يكون محله النصب على المفعولية، "ومتعلق الاستخبار محذوف، تقديره: إن أتاكم عذاب الله أو أتتكم الساعة مَنْ تدعون، ثم يبكّتهم بقوله تعالى: عادتكم إذا أصابكم ضرّ ، أم تدعون الله دونها"(").

\section{الفعـلـل الإنجازي المتضمن في القول:}

الآية لها قوتين إنجازتين تواكبان نفس المحتوى القضوي حيث تتجز

فعل السؤال المدلول عليه حرفيًا بقرينـة بنيويـة وهي أداة الاستفهام (الهمزة)،

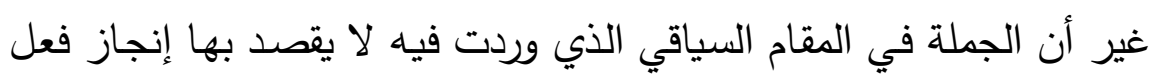
السؤال، وإنمـا أنجز بها فعل (التعجيز) والذي يمثل لنا فعـلاً كلاميًا غير مباشر؛ لأن الفعل المباشر هو فعل السؤال.

وقد بدأ التعجيز بـ(قل) التلقينية "وهي في كل تلك المواضع لم تكن إلا خطابًا للرسول محمد ولئل وهو خطاب يدل على أن من وراء الرسول وحيًا

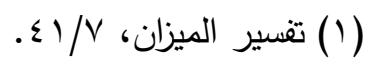

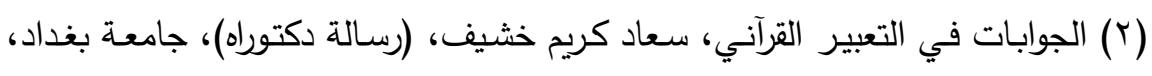

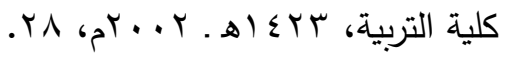

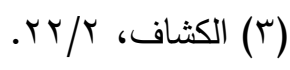


يوحي إليها بالإجابة عما سُئل عنـه، والتبليغ بالأحكام والثـرائع، ومن وراء الوحي رب العزة عظم شأنه"(').

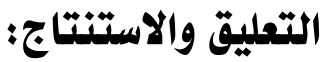

لقد اشتملت هذه الآيـة على فعل الاستفهام الذي يعود إلى الجانب الوصفي المتمثل في وصف الكافرين (أَتَأَنْتُعُم) فعل تلفظي كلامي وصفي

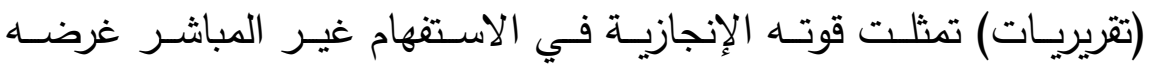

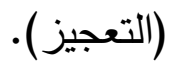
ويمكن توضيح بنية الفعل الكلامي كما يلي: المعنى الصريح . الاستفهام ـ فعل كلامي مباشر

/ المعنى المستلزم ـ التعجيز. فعل كلامي غير مباشر

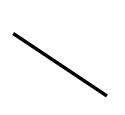

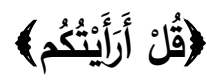

فلما خلص الاستفهام إلى الإفصاح بالمعنى التعجيزي، اختفى الطلب، بمعنى أن عنصر الإرادة يغيب عن الاستفهام الإفصساحي، بحيث لا يكون

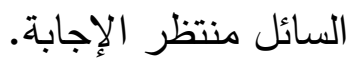

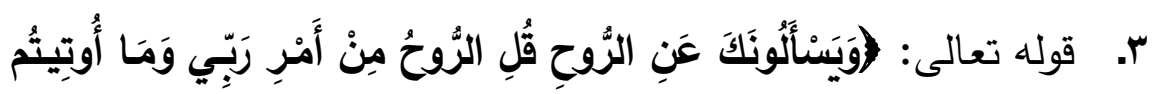

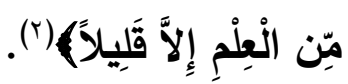

(1) الدصدر السابق، الصفحة نفسها.

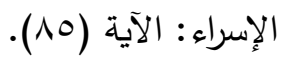




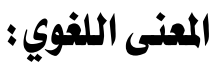

"الرَّوح والرُّوح في الأصل واحد، وجعل الرّوح اسمًا للنفس؛ وذلك لكون

النفس بعض الروح كتسية النوع باسم الجنس، وهو المذكور في قوله تعالى:

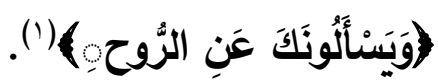

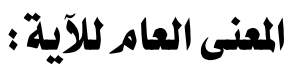

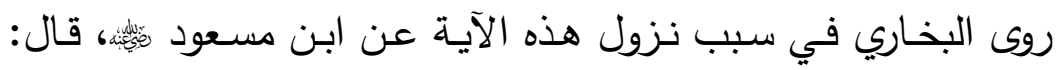

"كُنتُ مـع النبي

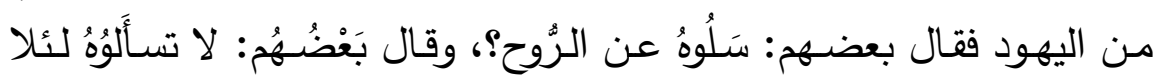

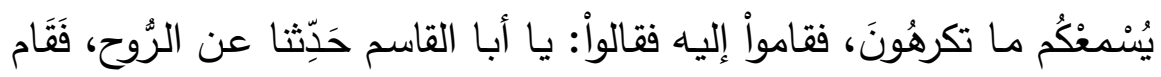

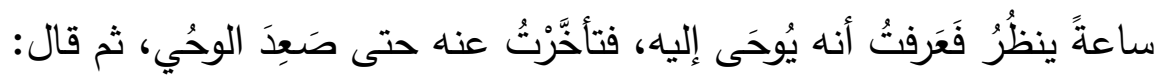

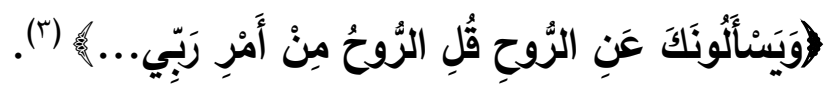

وقد اخْتُلفَ في السائلين عن الروح في هذه الآية، فسبب النزول يُبين

أن اليهود هم الذين سألواً عنها، وقال القرطبي فيروي عن ابن عباس ـ رضي الله عنهما ـ قوله: "إن السائلين عن الرُّوح هم قُريش، قالت لهم اليهودُ: سَلُوهُ

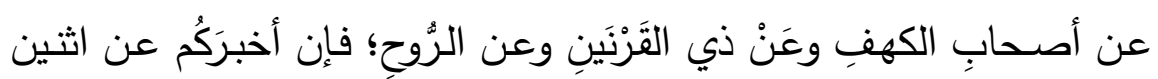

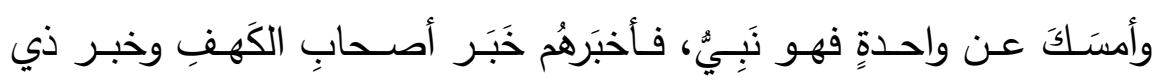

$$
\begin{aligned}
& \text { (1) المفردات في غريب القرآن، /97 (ر و ح ح). } \\
& \text { (Y) عسيب: عصا من جريد النخيل. }
\end{aligned}
$$

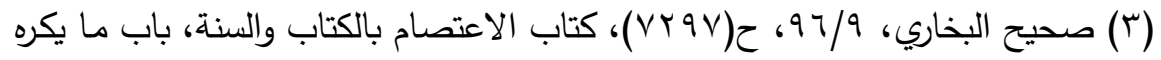

من كثرة السؤال وتكلف ما لا يُعنيه. 


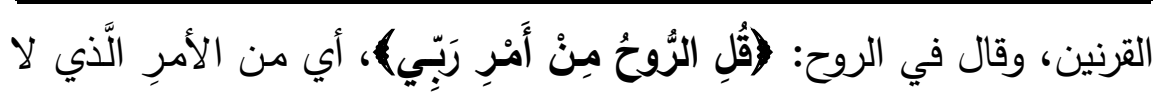
يعلَمَعُ إلا الله" (').

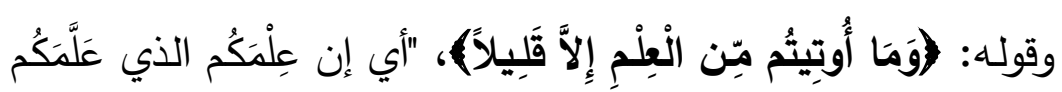

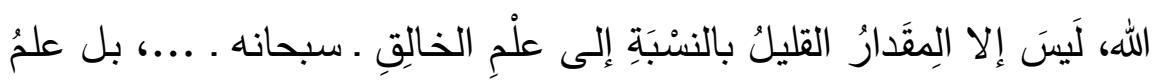

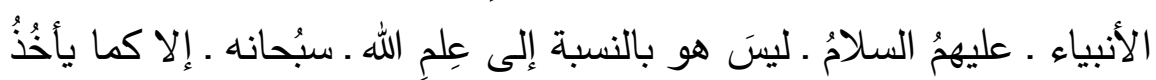

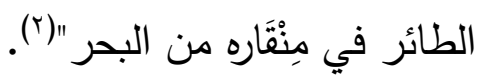

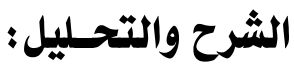

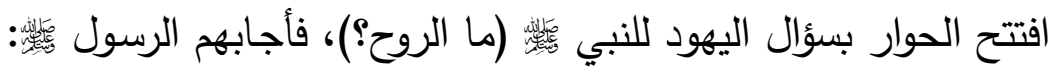

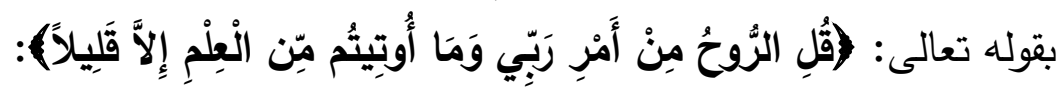

أ ) الافتراضات المسبقة(r): اليهود على علم مسبق بماهية الروح باطلاعهم

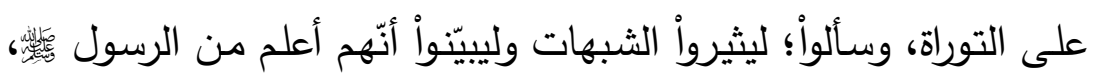

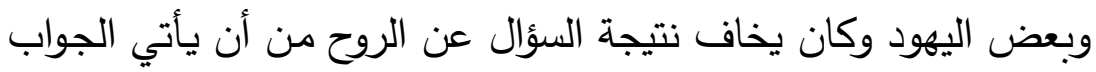

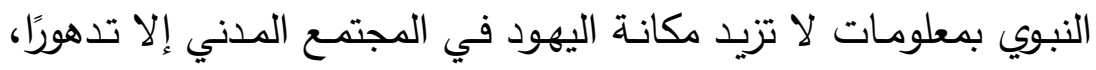

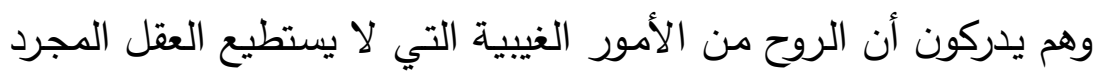

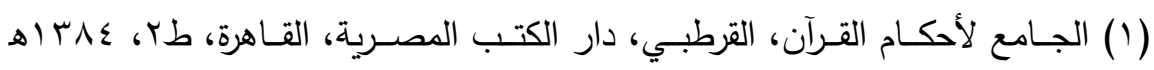

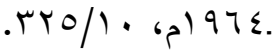

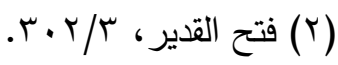

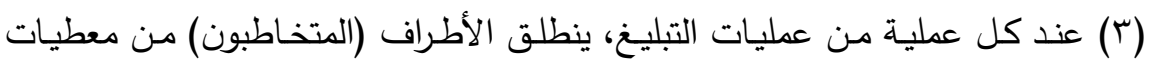

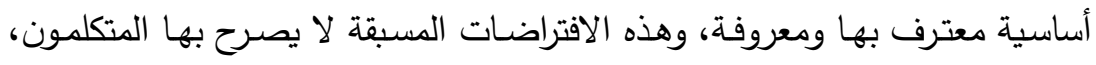

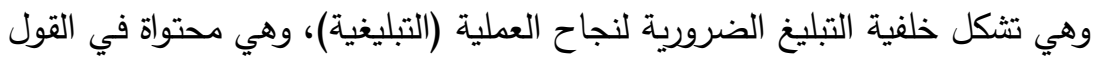

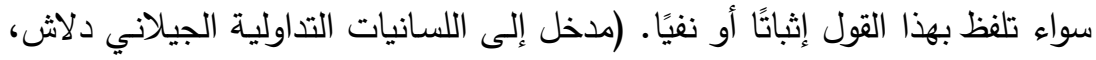

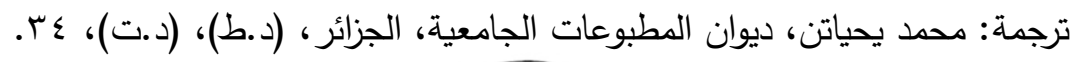




\section{الأفعال الكلامية في آيات التعجيز في القرآن الكريدر دراسة تداولية}

أن يبحث فيها دون الرجوع إلى النص معنى الملفوظ ليس هو القصد الدال على المتكلم بالذات، بل هو المعنى الذي يستخرجه المخاطب إن الملفوظ منطلقًا في ذلك من بنيته الدالة ومعتمدًا على مجموع الكفايات التي يمتلكها المتكلم وحادسًا قصده الدلالي. والاقتضاء يظهر الحيرة التي كان عليها اليهود والخوف الذي انتابهم.

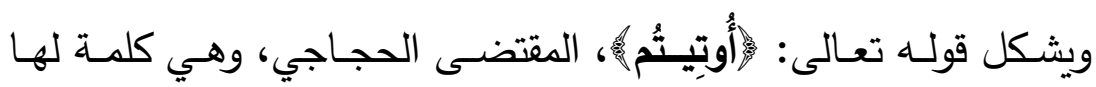
حمولتها الدلالية حاجج بها متلقيه دون غيرهـا من الكلمات؛ لأن أصل العطاء من الله لا من غيره.

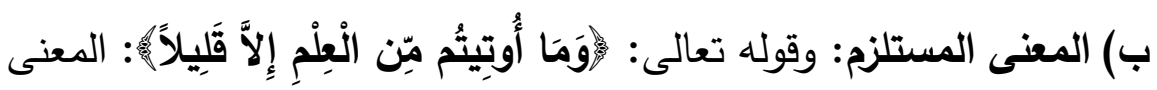

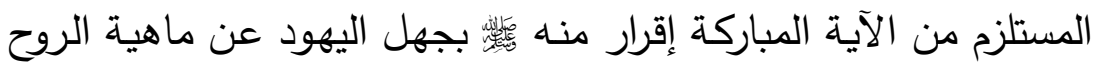

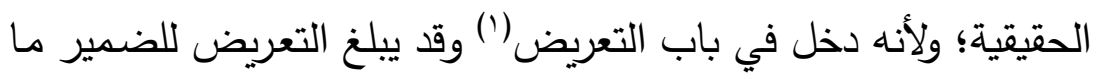
لا يبلغـه التصـريح، ويُعد التعريض مـن أسـاليب التداوليـة؛ لأن المرسـل يمكن استعماله؛ لأنـه أبلـن للفهم "والتعريض مـن الآليات الاستراتيجية التلميحيـة المستعملة عند العرب بكثرة في خطابـاتهم، فقد اعتبر مـن علامات الكفاية التداولية عند الرسل ودليلاً على النبوغ الخطابي يستعمل لغايات معينة ومقاصد متنوعة ومراعاةً لما يتطلبه السياق، "حيث يرتبط

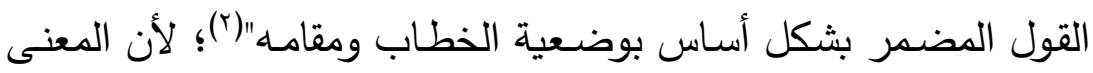
الناتج من هذه التقنية لا يدل عليه ظاهر اللفظ، وإنما يستنبط من خلال

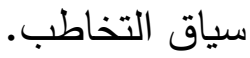

(1) التعريض: "وهو اللفظ الـال على الثـيء مـن طريق المفهوم بالوضـع الحقيقي

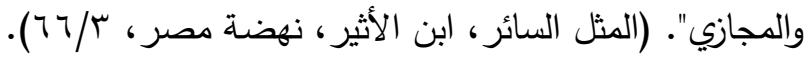

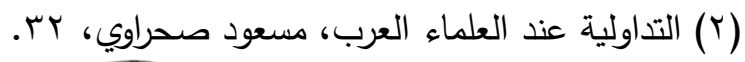




\section{الفعل الإنجازي المتضمن في القول: الم}

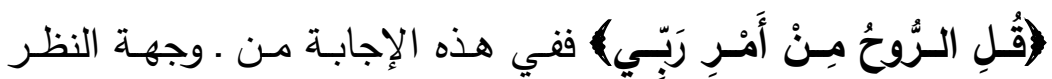

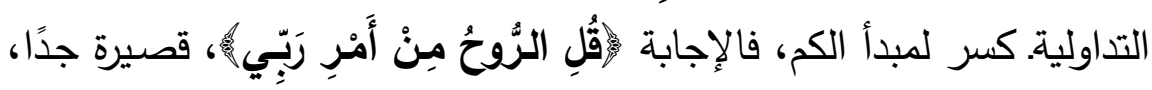

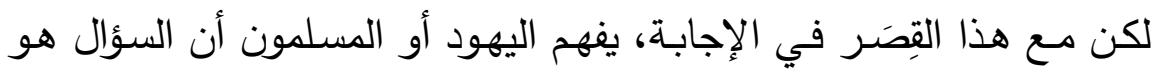
أكبر من فهمه وإدراكهم؛ لذلك كانت الإجابة بمعنى صرف عن مثل مثل هذه الإنه

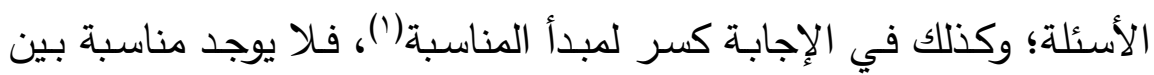

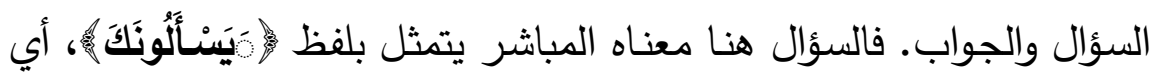
استفهم واسـأل وطلب الفهم عن شيء مجهول، وأمسا معناه غير المباشر

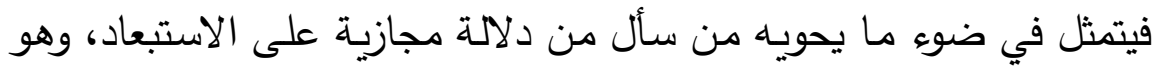
سياق إنتاجي توكيدي ترشَّح من التتابع الكلامي.

وهنا يكمن البُعد الضمني للتعريض والتداولية إذ أنهما "معًا يعملان إنان

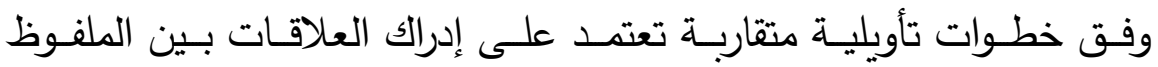

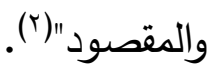

إذن فالآية تدل على الإخبار بحسب الفعل الكلامي اللفظي المباشر

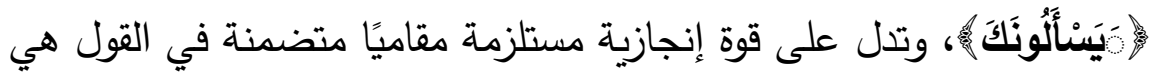

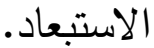

(') يتفرع عن مبدأ التعاون أربعة مبادئ فرعية، تتدرج تحت كل واحدة منها قواعد أكثر

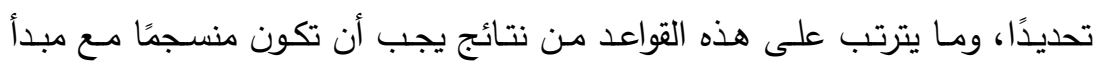

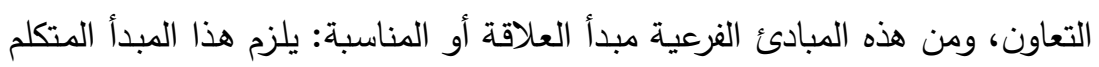

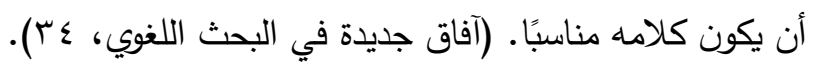

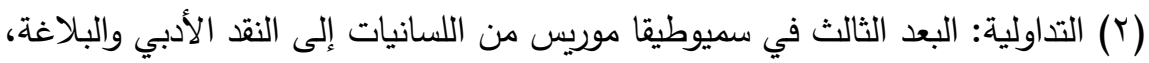

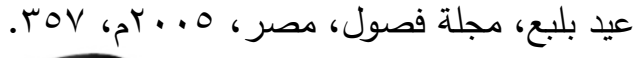




\section{الأفعال الكلامية في آيات التعجيز في القرآن الكريدر دراسة تداولية}

وتأسيسًا على مـا تقدم يمكن أن نلمح القوة الإنجازيـة للفعل الكلامسي كما يأتي: - n - n

المحتوى اللفظي ٪ سأل، الواو (فاعل)، الكاف (مفعول بـه) عن

والمحتوى القَضَوِي ـ ـ

القوة الإنجازية والتأثيرية ـ الاستبعاد والتشكيك والتعجيز •

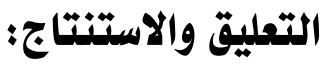

ومما يحسن قوله أن الاستفهام لم يرد بإحدى أدوات الاستفهام، لكنـه

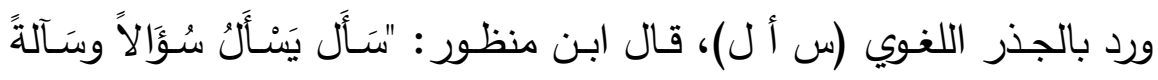

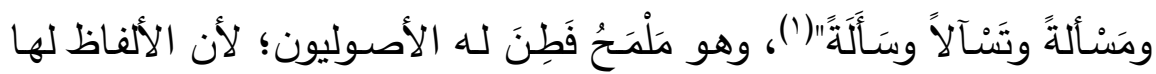
مؤدَى واقعي، ويترتب عليها قوة إنجازيـة وتأثيريـة في توجيه الحكم الثرعي،

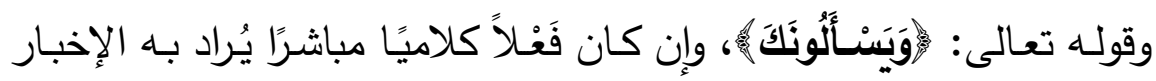
عمن لم يسبق ذكرهم وحسن ذلك ههنا؛ لأن حالة النزول كان السائل هذا

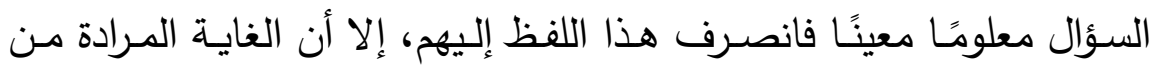
السؤال هنا الاستبعاد والتعجيز • 


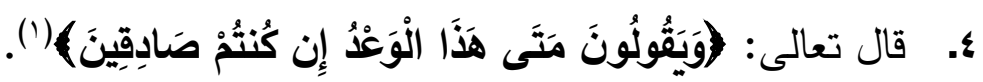

المعنى العامر للآيةه:

تكررت هذه الآيـة ست مرات في ست سور ، فهي مكونـة من ثلاث

جمل تكررت في سور متفرقة(؟)، والملاحظ في تكرار هذه الآية أن جميع السور التي تكررت فيها سور مكيّة، وقد تفرقت هذه السور على أجزاء المصحف، وفي هذا إشـارة إلى إكثار الكفار من هذا السؤال: (مَتَّى هَذَا

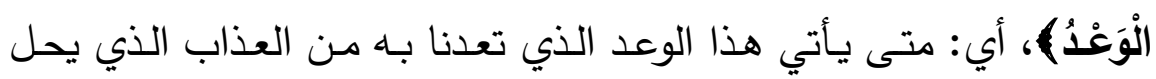

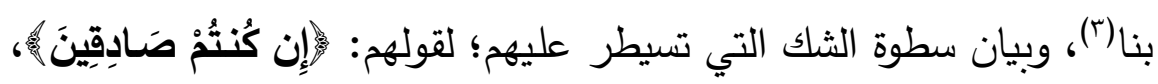
ولمــا في سـؤالهم مـن تهكم وســرية، وهـو "سـؤال متعنـت مسـتبعد لقيـام

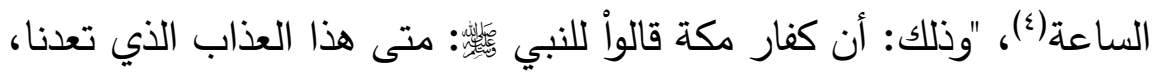

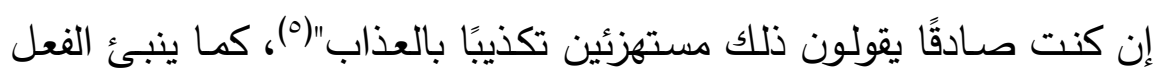
المضــارع (يقولـون) بالاسـتمرارية على ذلـك السـؤال، وهـو واقـع مـن قِبَـلن المعرضين إلى يومنا هذا.

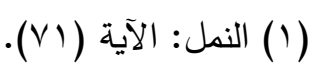

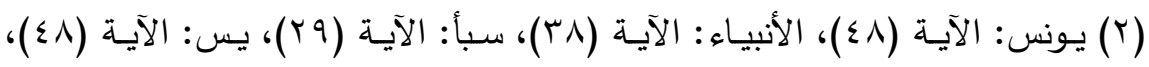

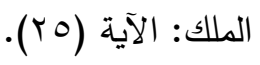

(ץ) الهاية إلى بلوغ النهاية، مكي بن طالب القيسي، تحقيق: مجموعة من الباحثين،

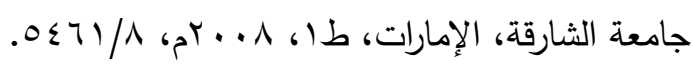

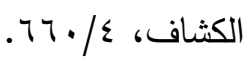

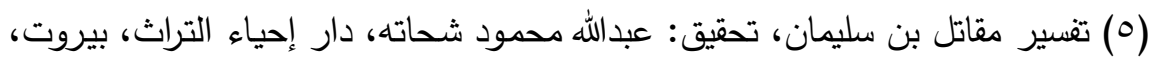

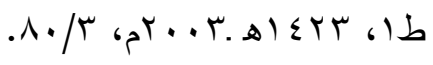




\section{الشرح والتحـليل:}

وردت (متى) مرة واحدة في سورة النمل لتفيد الاستبعاد، أي بيان سفه

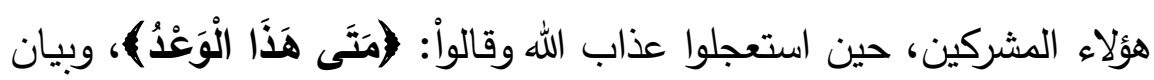
عُشُوهم وطغيانهم؛ لأن هذا الاستفهام كان على سبيل السخرية من هؤلاء المشركين وإنهم يقولون إن ما تعدوننا كذب بدليل أنه لم يقع، وهو دليلٍ أيضًا

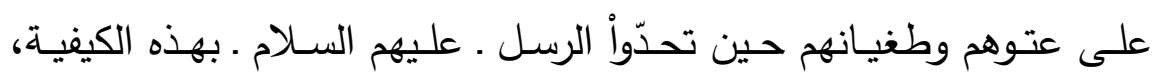
والظاهر أنه من باب التحدي والتعجيز ، يدل عليهم قوله تعالى : (إِن كُنتُمْ صَادِقِينَ)، ومثل هذه العبارة تكون تحدي ('). ولقد وضح الشوكاني غرض الاستفهام بقوله: "والاستفهام منهم للإنكار والتوبيخ والاستبعاد وللقدح في النبوة"(؟)؛ لأن الله يخبرنا عن استبعاد الكفرة

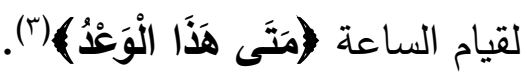

\section{الفعل الإنجازي المتضمن في القول:}

إن مجرد التكذيب كغرض للاستفهام في هذه الآيـة الكريمـة ليس لـه

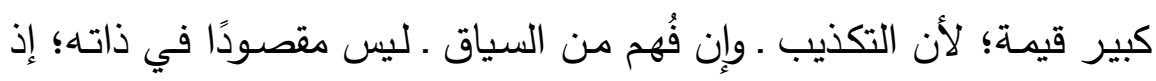
هم يعتقدون هذا القول، فوجب أن يقترن بالتكذيب معاني أخر هي: التعجيز

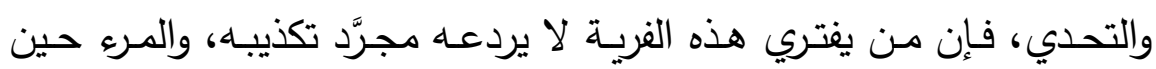

(1) تفسير القرآن (سورة النمل) محمد بن صـالح العثيمين، مؤسسـة الثيخ محمد بـن

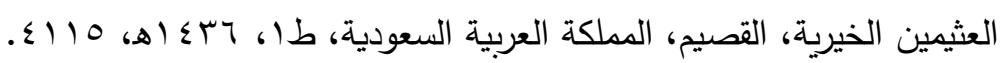

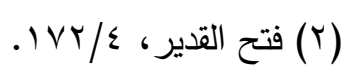

(r) إعراب القرآن الكريم وبيانه، محيي الدين درويش، دار الإششاد، حمص ـ سوريا، طء،

$$
. r \cdot 9 / 1
$$


يخطئ ثم يصرٌ على خطئه ويدافع عنه من دون علم، فهو أهل لهذا المعنى (التعجيز)؛ لأنه استمساك بخطأ جسيم دون استناد إلى على أو دليل. إذا كان هذا دليلاً منطقيًا، فإن في السياق ما يؤيد هذا المعنى كتأكيد

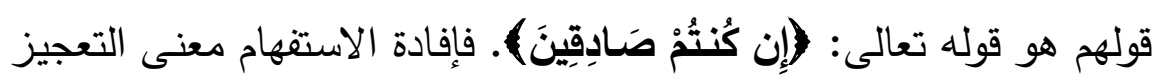

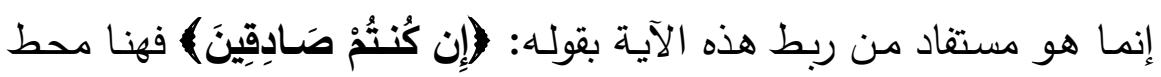
التعجيز وانطلاقًا من صيغة لغوية واحدة، نلاحظ ثلاث درجات في المعنى، أو ثلاث قوى إنجازية: ا. معنى الصيغة: السؤال (قوة إنجازية حرفية). r. معنى معنى : التوبيخ (قوة إنجازية مستلزمة). r. معنى معنى المعنى: الاستبعاد (قوة إنجازية مستلزمة).

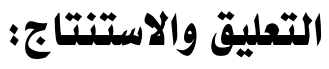

جاء الاستقهام هنا للتوبيخ والإنكار بقرينة المقام، ولعدم استقامة حمل الاستفهام على الاستفهام الحقيقي، ويتولـد منـه معنى الاستبعاد مـن حال

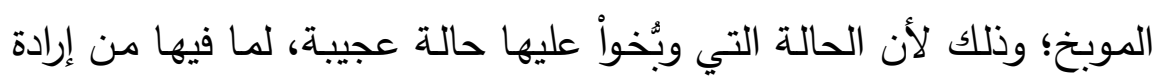
الخير للغير وإهمال النفس، فبعد أن تحدث الثوكاني عن خروج الاستفهام إلـى التـوبيخ أخـرج التوبيخ وهـو مسن قبيـل المعنـى المسـتلزم مقاميًا إلىى الاسـتبعاد، فقد تم العـدول مـن: الاستقهام إلى التوبيخ، ومـن التوبيخ إلى الاستبعاد. 


\section{الأفعال الكلامية في آيات التعجيز في القرآن الكريدر دراسة تداولية}

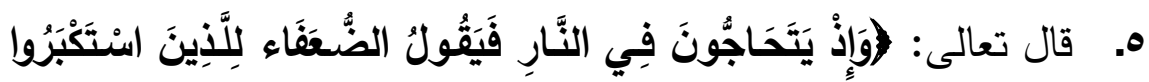

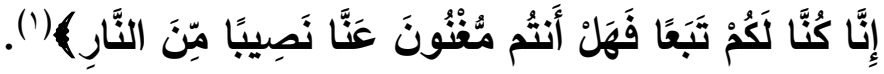

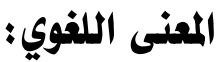

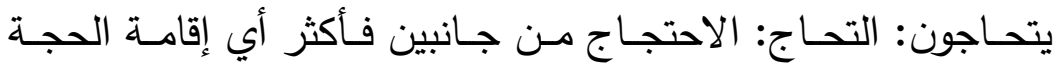

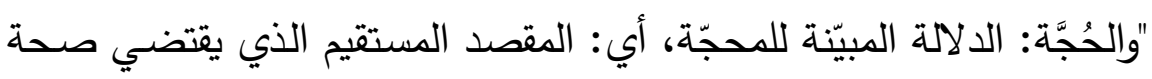

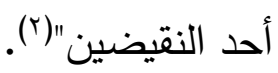

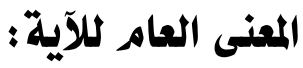

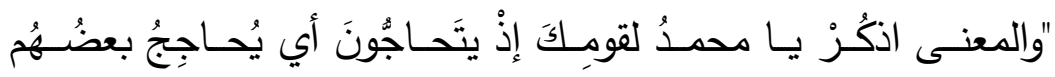

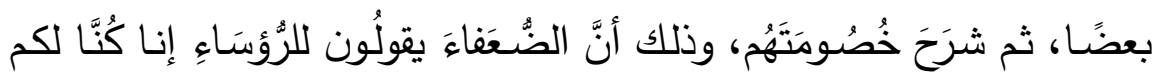

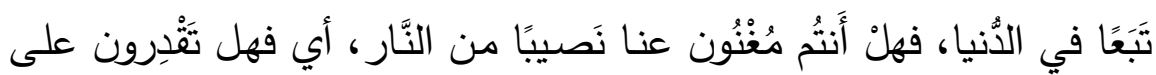

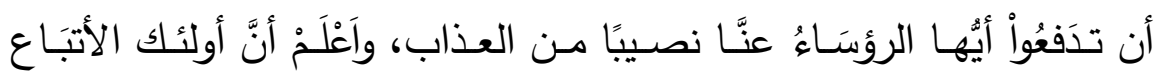

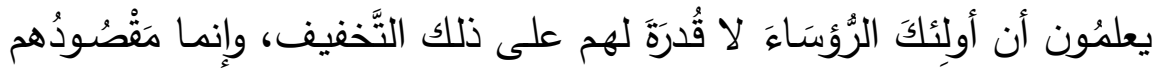

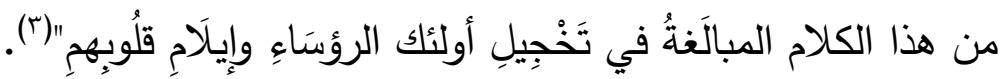

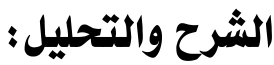

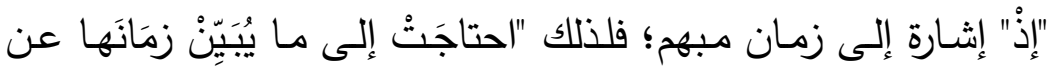

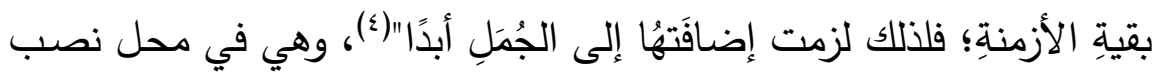

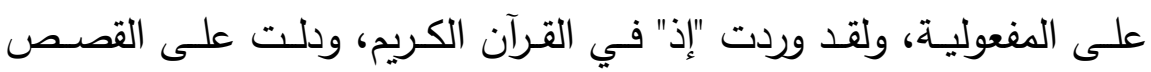

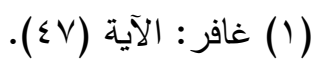

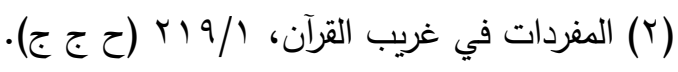

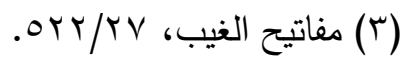

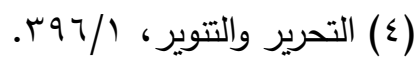


العجيبة، وابتدئت بها، وهذه القصص كانت دالة على قدرة الله تعالى، وتقدر "إذ" بفعل "أذكر"، ونظيره كثير في القرآن الكريم، وهو حذف، والحذف مطية للتضمين في البُعد التداولي، وقد حذف هنا المسند إليه فقامت القرينة مكانه وهي "إذ"، والغاية من الحذف هنا هي الاحتراز عن قول ما ليس لله فائدة، وهو للاختصار أيضًا ولإيجاز .

ويُعدّ ذكر المحذوف زيـادة عن الحاجـة، من نواقض قاعدة الكم في مبدأ التعاون عند (غرايس، Crice)، الذي ينص على "ألا تجعل مساهمتك إخبارية بالقدر الذي يفوق المطلوب"('). فكان معنى الاستفهام واضحًا، وهو الإنكار مـع التوبيخ، أي إنا فعلنا في الدنيا من ظلم وتكذيب ما كان ينبغي أن يكون.

ونلاحظ في الآية أن الاستفهام دخل على جملة اسمية، مع أن "هل"

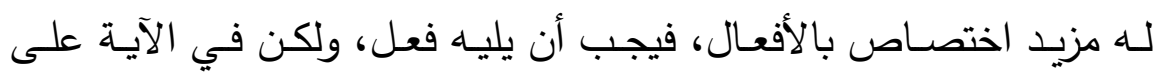
خلاف ذلك، ولا يكون ذلك إلا لهدف ومعنى، يقول بعض البلاغيين: "إن

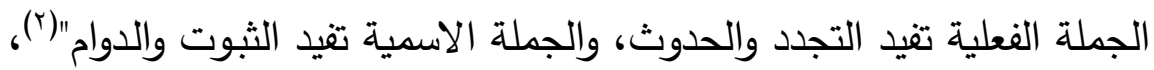
فالمراد منه، وضـع ما سيتجدد في موضع الثبوت والدوام، لزيادة على حصول ذلك، ورغبتهم الثديدة في حصول الإغناء من عذاب النار، فكان: "هل أنتح" قبل دخول الاستفهام أقوى على طلب الدفع والاهتمام بوقوعه من أن تعتبر بالجملة الفعلية (تغنون عنا) بعد ما دخل عليها الاستفهام وهو يفيد الإنكار

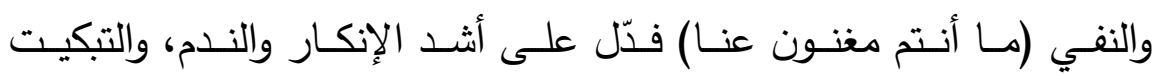
والتعجيز 


\section{الفعل الإنجازي المتضمن في القول:}

عمل الاستفهام معنى الطلب وهو الأمر ؛ لأنهم حينئذ يحتاجون إلى لى

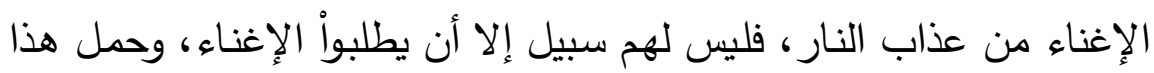

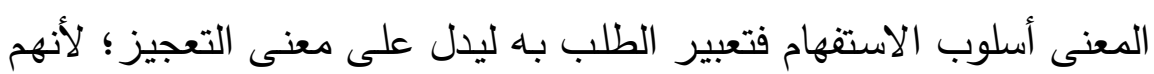

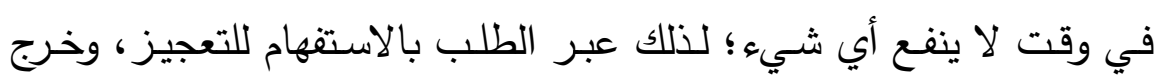
الفعل الإنجازي المباشر إلى معنى إنجازي غير مباشر يفسره المقام الذي لإني ورد فيه، وهو غرض التعجيز.

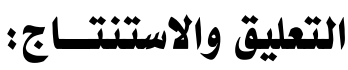

بعد عرض هذه الآية تبين أنها قد احتوت على التركيب الذي يمثل

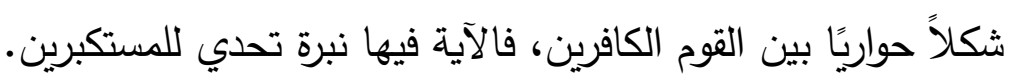

\section{تعقيب عــاه على هذا المبحث:}

في هذا المبحث تناولت الآيـات القرآنيـة التطبيقيـة لنظريـة الأفعـال

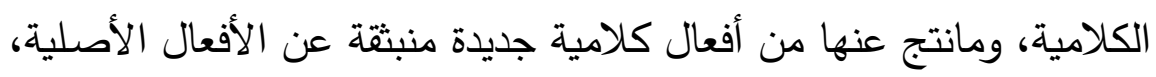

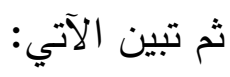

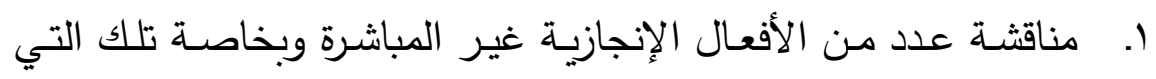
تكون استفهامًا مقصودًا به الطلب، فلا يقصد القول فحسب، بل يتعدى الإنى القصد إلى ما هو أكثر منه وهو غرض التعهان التعجيز. r. الأفعال الإنجازية غير المباشرة لا تدل هيئتها التركيبية على زيادة في

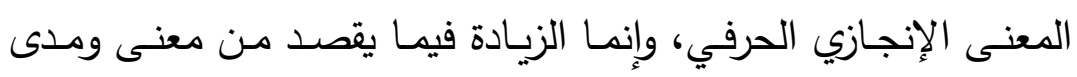

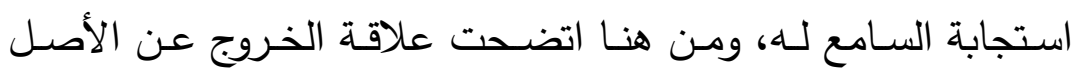

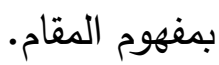

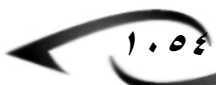




\section{المبحث الرابع}

\section{الاسترسال التداولي لأفهال الكلاه بيز الأمر والاستفهاه}

توطئهة :

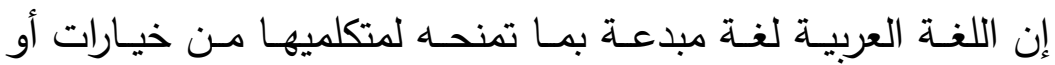
استراتيجيات لغويـة وتركيبية وفقًا لأبعاد كثيرة، منها: المتكلم، والمخاطب، والسياق، والمقام بظروفهه وملابسـاته ... إلخخ. يظهر مـن ذلك أن "المرسل يستطيع أن ينجز أكثر من فعل من الأفعال اللغويـة في آن واحد، إذا اعتمد على الثنائيات التي تتتمي إلى صنف واحد، كما في إنجاز فعل الأمر وفعل النهي في آن واحد مـن خـلال التلفظ بأحدهما"(')، ولكن كل ذلك مرهون بسياق الموقف وظروفه المختلفة، وليس على إطلاقه "لكن ذلك لا يكون إلا عن طريق الاقتضـاء"(؟)، ووجدت ما يشير إلى ذلك من آيات التعجيز في القرآن الكريم للآيات التالية:

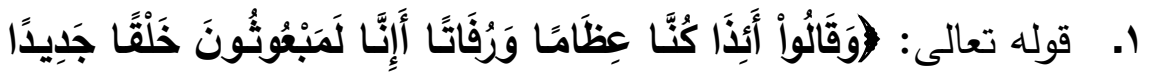

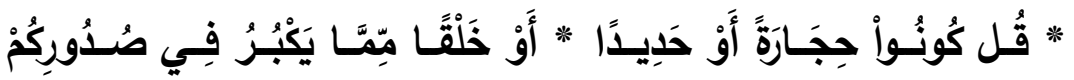

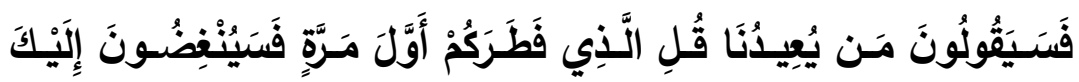

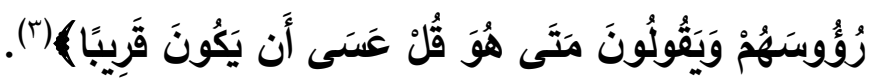

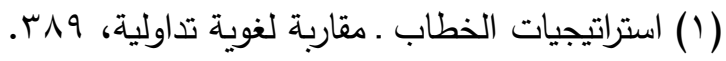

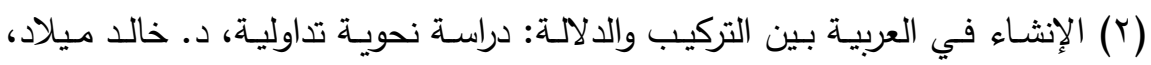

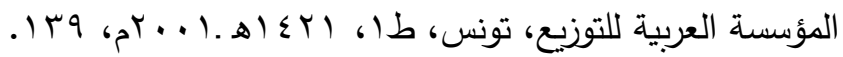
الإسراء: الآيات من (9 §) إلى الآية (1) (1). 
المعنى اللفوي: - nمي

عظام: "العين والظاء والميم أصلُ واحد صحيح يُدلُّ على كِبَر وقُوَّة،

وعَظْمَةُ الإِّراع: مُسَتَغْلظُهَاِ" (1).

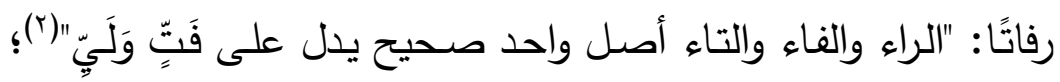

فسينغضون: "الإنغاض: تحريكُ الرأس نحو الغير كالمتعجِب منه"(־).

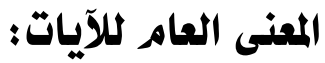

"يقول تعالى مخبرًا عن قيل هؤلاء الذين لا يؤمنون بالآخرة من مشركي

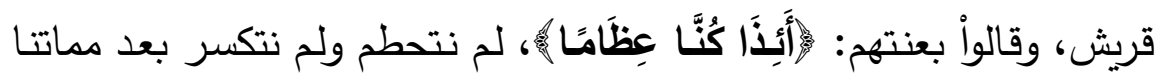
وبلانا (ورفاتا) يعني ترابًا في قبورنا"(؛)؛ "لهذا كانت جُملةُ قل كونوا حجارةً ... إلخ غير معطوفة، ... ، واعلم أن ارتباطَ ردّ مقالَتِهح بقوله: كُونُوا حجارةً

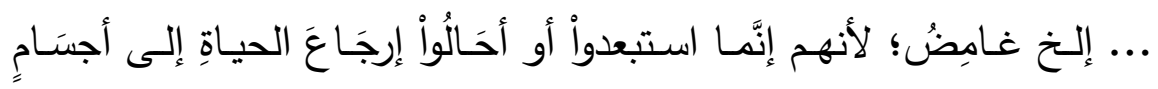

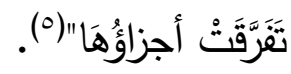

\section{الشرح والتحليل: - | (الثيل}

دلَّ التعبير القرآني بتأثير عن سياقه السابق على التعجيز مع الإهانة "في مقام عدم الاعتداد بالمخاطب وقلة المبالاة على أي وجه كان ... [ف] الأمر في الآية (كونواً) لا يُراد بـه حقيقته، وإنما المراد منـه (الإهانـة)؛ لأن

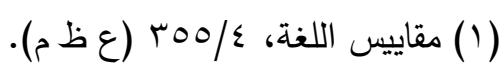

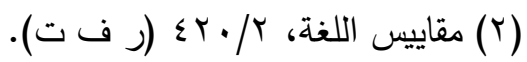

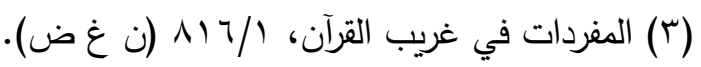

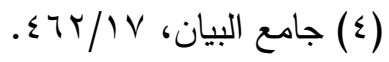

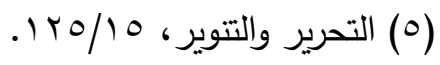


الفعل ليس في طاقة المخاطبين، وطلب أن يكونوا حجارة أو حديدًا فيه إهانـة لهم، وسر بلاغة التعبير إظهار التهكم بهم حتى يلتفتوا إلى ما هم فيه من

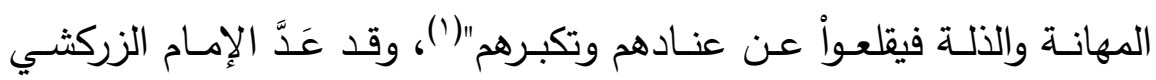
التعبير من باب التعجيز (؟). وخروج الأمر عن دلالته الحقيقية إلى دلالة التحدي والتعجيز بعاملين اثثين، هما: ا. السياق السابق للنّص: المتمثل في سؤالهم الاستنكاري حول يوم البعث والمقترن بشيء يرونه مستحيلاً ألا وهو خلقهم من جديد، إذ قالوا:

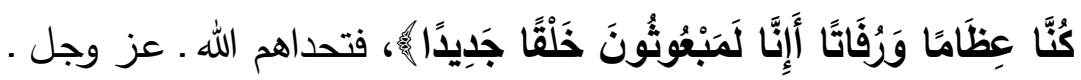
بمـا هو أكبر وهـو خلق الحجـارة أو الحديـد، أو خلق ممـا يكبر في صدورهم "فإن قدرته تعالى لا تقتصر عن إحيائكم لاشتراك الأجسام في قبول الأعراض، فكيف إذا كنتم عظامًا مرفوته"(r). r. المصـاحبة اللغويـة: يقول عرفات فيصل المناع: "إذًا لا توجد في اللغـة

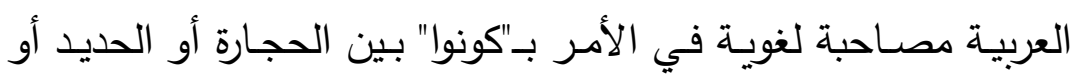
الخلق الذي يكبر في صدورهم وهو المـوت، فدلّ هذا على انحراف معنى الأمر إلى معنى آخر تدلّ عليه عناصر السياق الأخرى"(£).

(1) أساليب المعاني في القرآن، السيد جعفر باقر الحسيني، 11 اـ بام، 01.

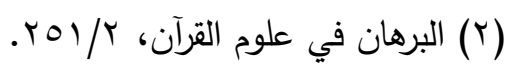

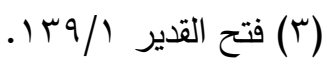

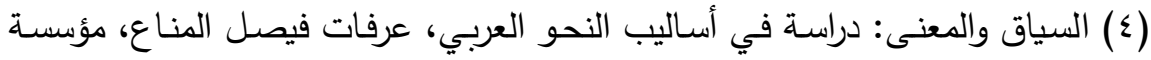

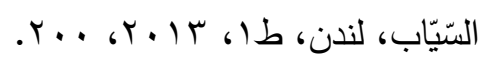




\section{الأفعال الكلامية في آيات التعجيز في القرآن الكريدر دراسة تداولية}

\section{الفعل الإنجازي المتضمن في القول:}

1. في الآيات السابقة هناك معان مضمرة غير المعاني الصريحة التي دَلّ

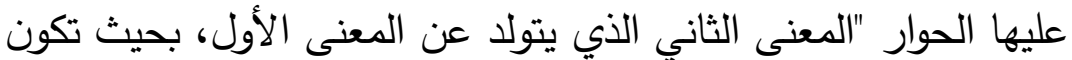

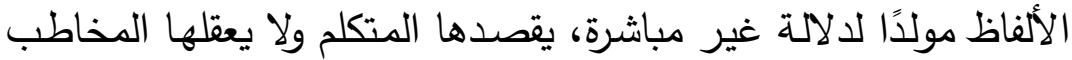

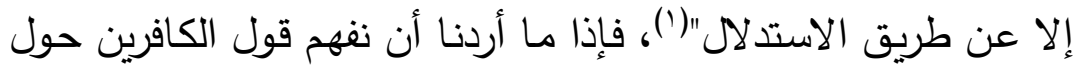

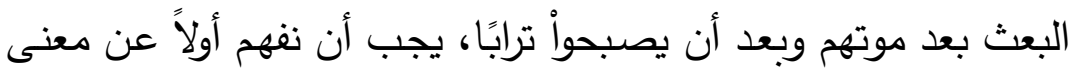

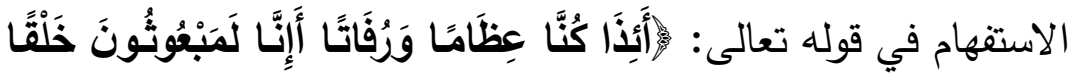

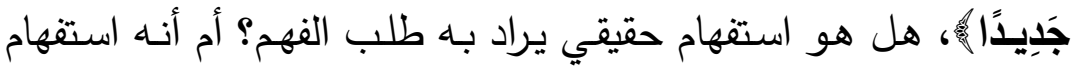
إنكار يراد به إنكار هذا اليوج؟ "الهمزة للاستفهام الإنكاري مفيدة لكمال

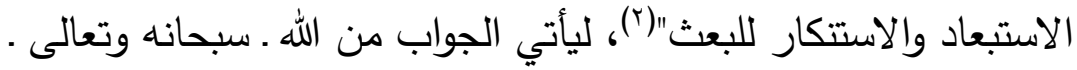

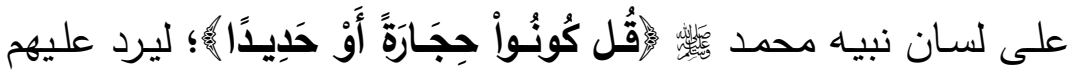
إنكارهم واستبعادهم ليوم البعث بعد موتهم وبعد أن يصبحواً عظامًا

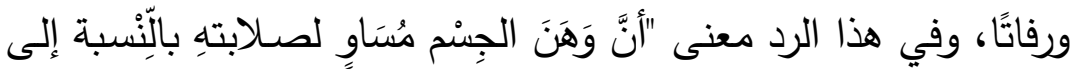
قدرة الله تعالى على تَكْيِيفه كيف يَيَّاءُ" ("). r. جاء هذا الرد خرقًا لقاعدة المناسبة، حيث لا مناسبة بين قول الكافرين والرد عليهم، فهم يتساءلون عن إمكانية بعثهم وإعادة خلقهم من جديد

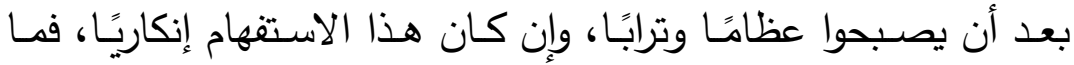
علاقة الجواب (قل كونوا حجارة أو حديدا) بالسؤال؟ إن الإجابة التي

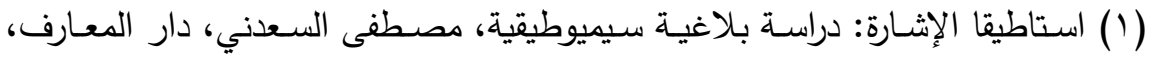

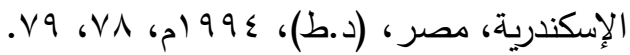

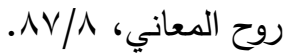

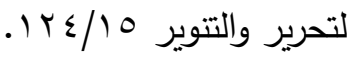


كان ينتظرها الكافرون قد يكون (نعم إنكم مبعوثون)، أو (لا تبعثون)،

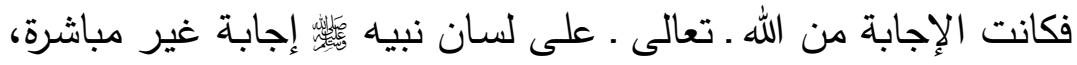
لكن هذه الإجابة مفهومة جيدًا من قبل الكافرين، وهذا هو مبدأ التعاون. r. من وجهة النظر التداولية: أن الأفعال الكلامية التوجيهية في هذه الآية، هي الاستفهام، الذي هو طلب الاستمرار والثبات على الإيمان، كمـا يوجد أيضًا جملـة من الأفعال الكلامية غير المباشرة، منها: التوبيخ والتعجب والإنكار والتأنيب.

\section{تمليق واستنتاج: - n}

1. جيء بالفعل (كونوا) ليقابل الفعل (كنا) وتقابُل الألفاظ (عظامًا ورفاتًا) مـع (حجارة أو حديدا) ويكون المعنى في ذلك: (إنكم مبعوثون سواء أكنتم عظامًا ورفاتًا أم كنتم حجـارة أم حديدا تتبيهًا على أن قدرة الله تعالى لا يتعاصى عليها شيء"('). r. والاستفهام في قولـه تعالى: (مَنْ يُعِيدُنَا)، استفهام تهكمي (؟) يُراد بـه التثكيك من قدرة الله، ثم يأتي الحوار حول شكهم في هذه القدرة، فقال

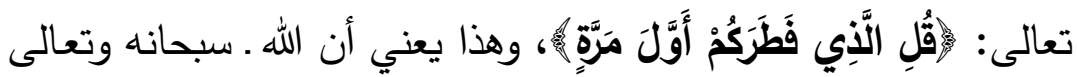

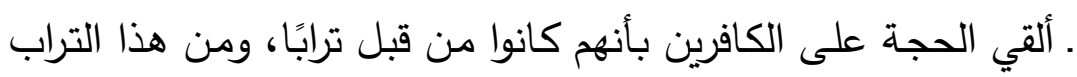
خلقهم، فالذي يخلق من التراب مرة يستطيع أن يخلقكم منـه مرة ثانية وثالثة. 


\section{الأفعال الكلامية في آيات التعجيز في القرآن الكريد دراسة تداولية}

r. انتقال الحوار إلى شك آخر الذي يظهره سؤالهم عن زمان هذا اليوم،

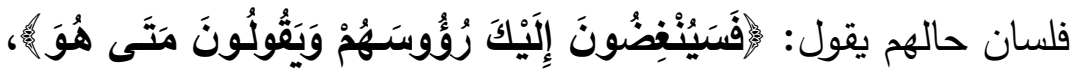
ففي سؤالهم هذا معنى التسليم بالثَّكَيْن السـابقين، فقد سلمواُ بقدرتهـ ـ. سبحانه وتعالى . على إعادتهم من جديد بعد أن صسارواْ ترابًا ليتساءلواً عن زمـن هذا اليوم الذي يبعـث فيـه الإنسـان مـن جديد (متى) اسـ اسـتفهام يحـال عـن الزمـان، ويمكن أن يكـون هــا الاسـتفهام تهكمًا وتشكيكًا، فمـا كـان الجواب إلا ردًا على تهكمهم وشكهم، فجـاء قولـه

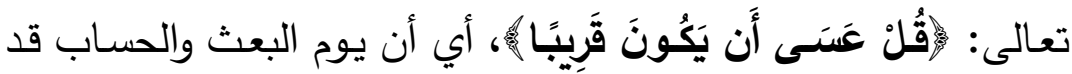
يكون قرببا "فإن ما هو محقق إتيانه قربب، ولم يُعين زمانهـ؛ لأنه من لن

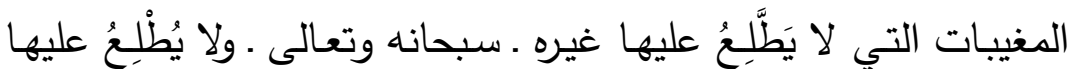

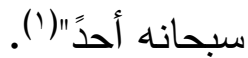

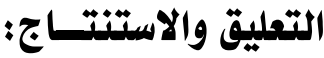

وعليه .. يجب أن ننظر إلى الأسلوب في محيطه اللغوي الكامل، إن أردنا أن نعطي فهمًا دقيقًا لمعناه؛ "لأن الأساليب في العربية تأخذ بعدًا شكليًا وآخر سياقيًا، يتمثل الثكليّ في ما اتَّقق عليه النحاة والبـاغيون، من صيغ وأدوات تميّزها عن غيرها، أمَّا السياقيّ فيتمنَّل في تفاعلها مـع عناصر لغويـة أو غير لغويـة، فينتج عن ذلك تغيير مدلولات تلك الأسـاليب، بـل إنـا قد نحصل على نقيض تلك الأسـاليب نتيجة لهذا التأثير والتأثر المتبادل فيما

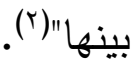

$$
\text { (1) روح المعاني } 10 \text { (1/19. }
$$
(r) السياق والمعنى، عرفات فيصل المناع، r. r. T. 


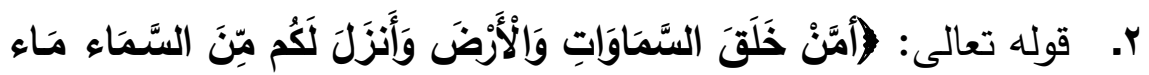

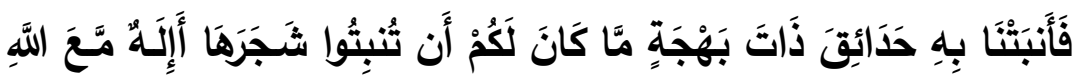

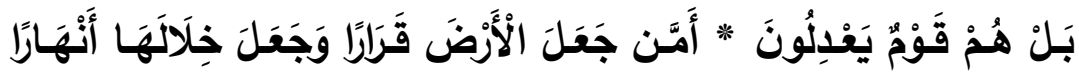

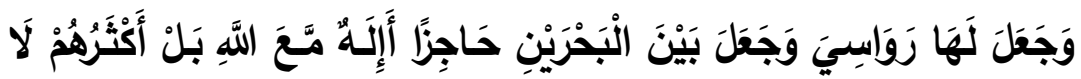

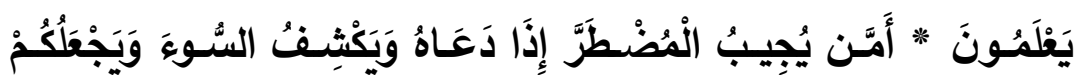

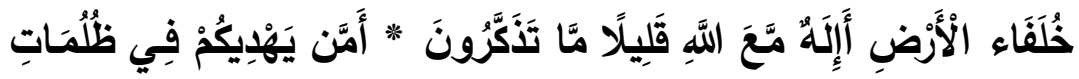

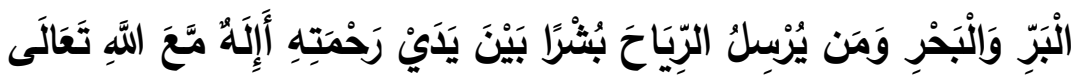

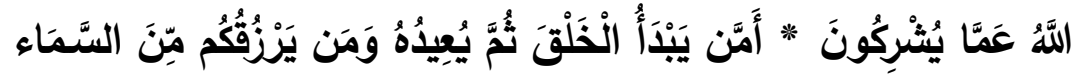

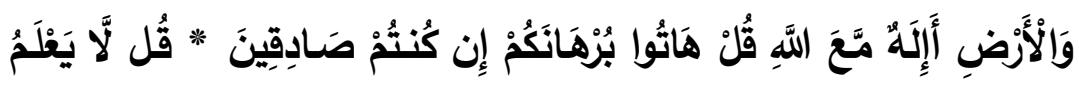

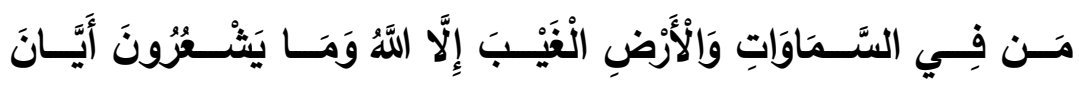

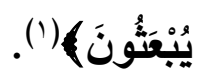

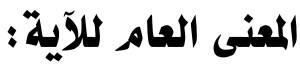

"أي: أعبادة ما تعبدون أيها المشركون من أوثانكم التي لا تضر ولا تنفع خير أم عبادة الذي جعل الأرض مستقر للإنسـان والدواب، وجعل في

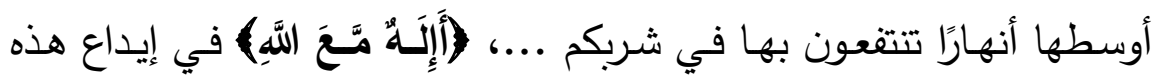

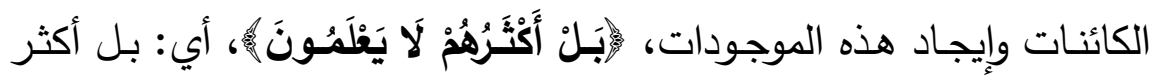

هؤلاء المشركين لا يعلمون قرر عظمة الله"(r).

$$
\text { (1) النمل: الآيات من (· (7) إلى (70). }
$$

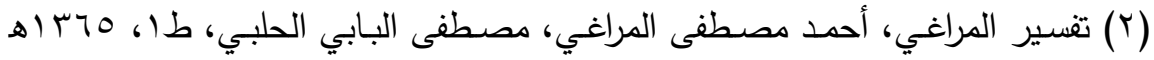

$$
.96 \Lambda / Y \cdot 619 \leq 7 .
$$


الشرح والتحـليل:

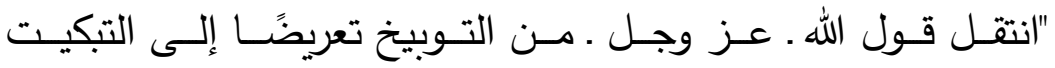

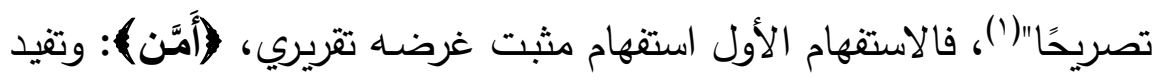

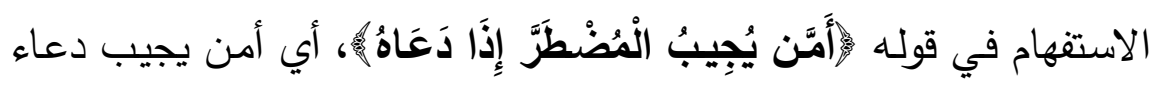

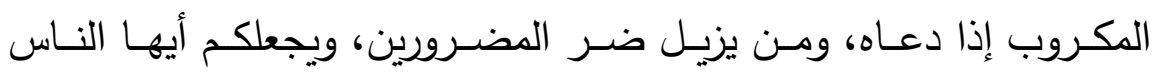

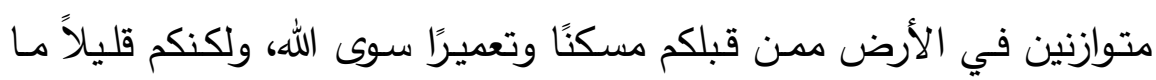
تتعظون"(r).

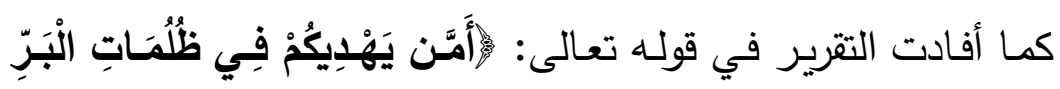

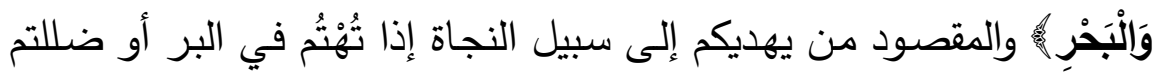

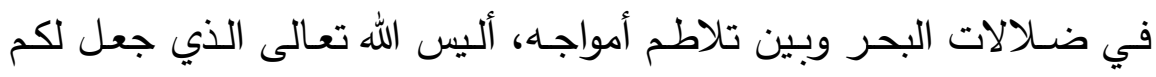

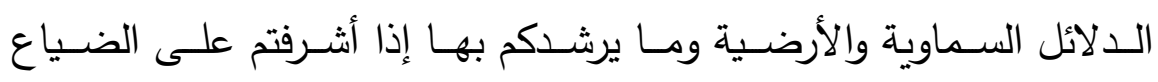

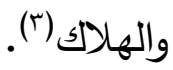

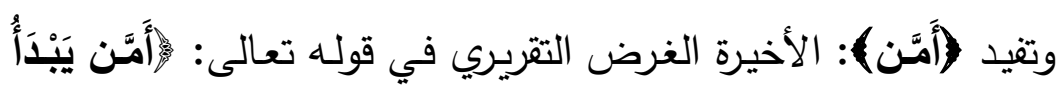

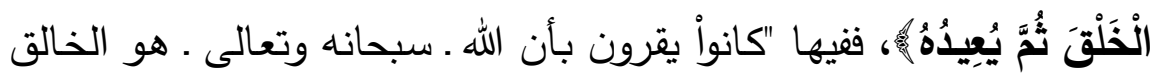
فألزمهم الإعادة، أي: إذا قدر على الابتداء قدَر على الإعادة، ومن يرزقُكُم

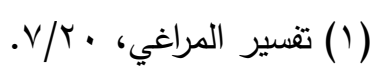

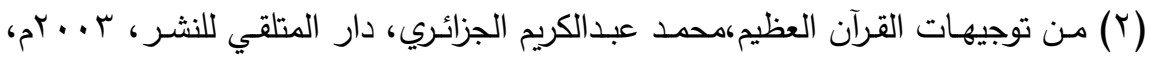

(r) التفسير المأمون على منهج التنزيل والصحيح المسنون، مأمون أحمد راتب حموش،

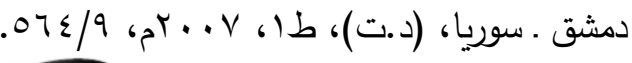


من السماء بالمطر والنبات، أي: هو خيرُ أم ما تجعلُونَهُ شريكًا لـه مما لا لا يقدر على شيءٍ من ذلك"(')

\section{الفعل الإنجازي المتضمن في القول:}

يرى (سيرل) أن مثل هذه الجملة (الجملة الاستفهامية) تتجز فعلين كلاميين، أحدهما مباشر تستدل عليه من المعنى الحرفي للملفوظ، وآخر غير مباشر يفهم من سياق الكلام وتنقل من أولهما إلى ثانيهما عبر سلسلة

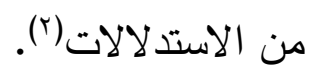

وأسلوب الاستفهام المصدر بـ(أمن) والتي تلته أفعال ماضية (خلق)، (جعل)، وأفعال مضارعة (يجيب)، (يهديكم)، (يبدأ)، وهذه الاستفهامات كلها مثبتة جاءت لتحمل المشركين على الإقرار والاعتراف والتدبر في الخلق، ملكها برهان على عظمـة ووحدانية الله، وأفادت (أيان) تعظيم المستفهم منهـ

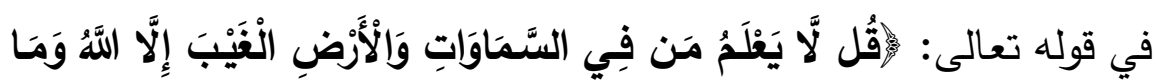

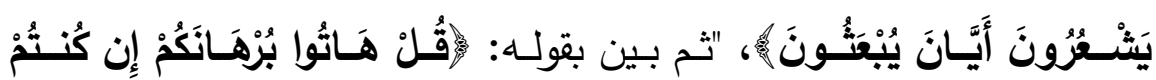
صَادِقِينَ

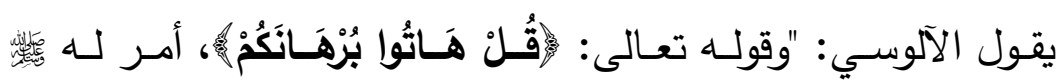

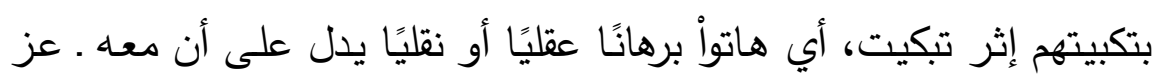

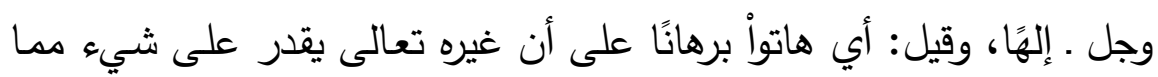
ذكر من أفعاله ـ عز وجل ـ وتعقب بأن المشركين لا يدعون ذلك صريحًا ولا إلا

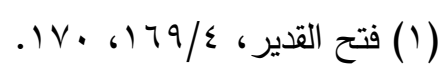

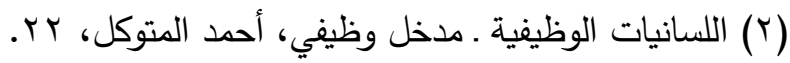

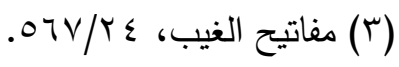




\section{الأفعال الكلامية في آيات التعجيز في القرآن الكريدر دراسة تداولية}

يلتزمون كونه من لوازم الألوهية وإن كان منها في الحقيقة فمطالبتهم بالبرهان عليـه لا على صـريح دعـواهم مدـا لا وجـه لـه، وفي إضـافة البرهـان إلـى

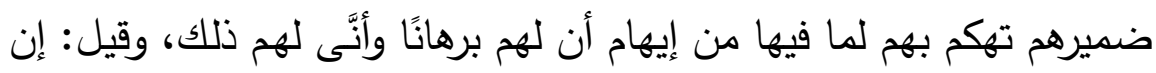

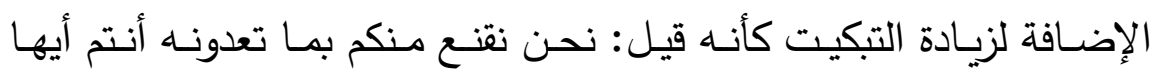
الخصوم برهانًا يدل على ذلك، وإن لم نعده نحن ولا أحد من ذوي العقول كذلك، ومع هذا أنتم عاجزون عن الإتيان به (إِن كُنتُمْ صَادِِِينَ)، أي في تلك الدعوى، واستدل به على أن الدعوى لا تقبل ما لم تتور بالبرهان"(').

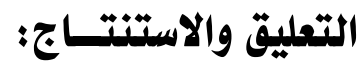

إذا كان النص القرآني قد وكل إلى المتلقي تأويل المعنى ما يتيح لـه

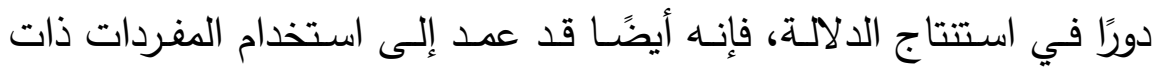
المعاني العامة، ويرجع الآلوسي تفضيلها إلى التأثير المتلقي؛ إذ تحديد معنى خاص يحدد مجال التأثير بهذا المعنى، أمسا استخدام الكلمات التي تحمل التوسي

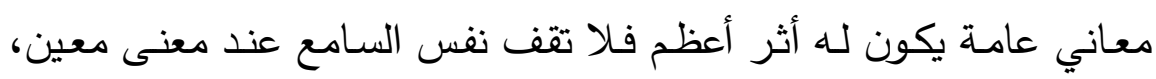
وهذا يتيح للمتلقي مجالاً أوسع وأرحب في استتتاج الدلالات المختلفة.

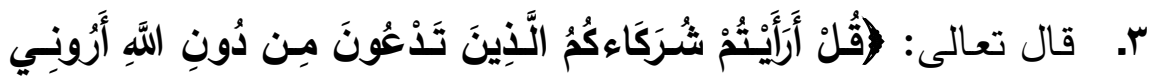

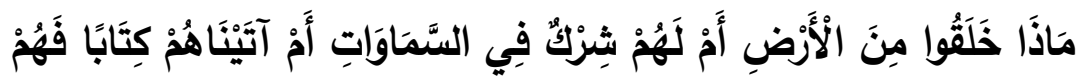

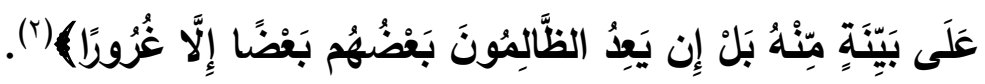

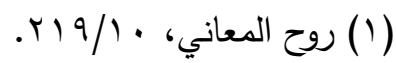

$$
\begin{aligned}
& \text { (r) فاطر : الآية (•ع). (1). }
\end{aligned}
$$




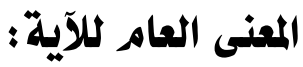

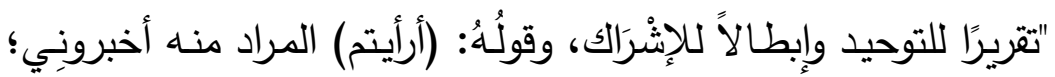

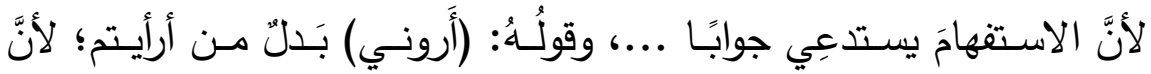

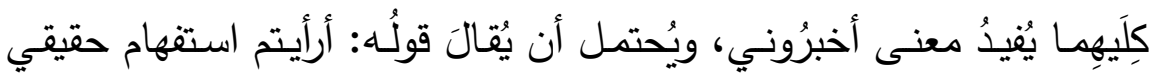

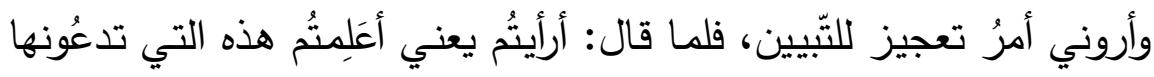

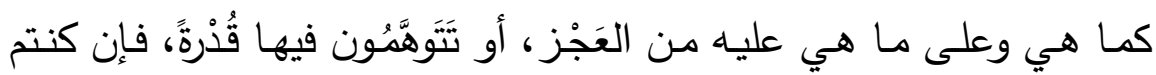
تعلمُونَها عاجزةً فكيف تعبُدونَها؟" (1).

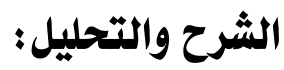

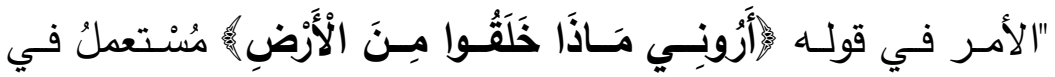

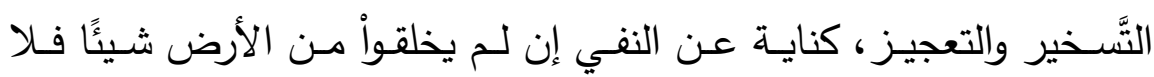

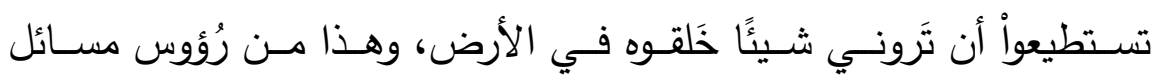

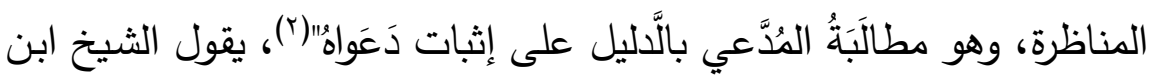
عاشور : "(أرأيتم) استفهام تقريري فهو كناية عن معنى (أخبروني)، و(ماذا) بمعنى ما الذي خلقوه والاستفهام في (ماذا خلقوا) إنكاري، والاستفهام المقدر فئري

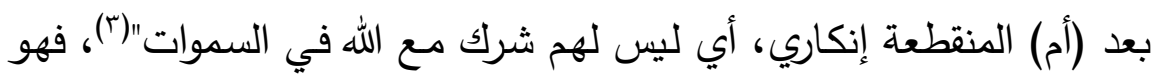

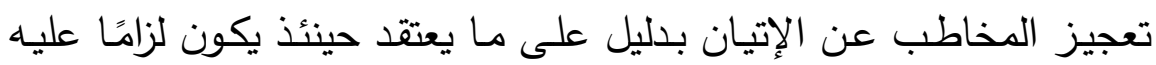

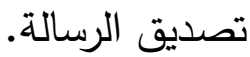

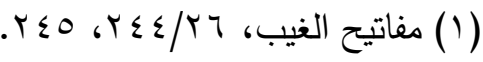

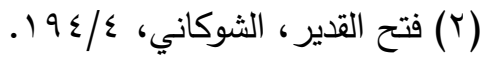

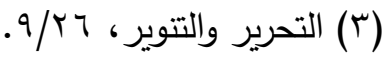




\section{الأفعال الكلامية في آيات التعجيز في القرآن الكريدر دراسة تداولية}

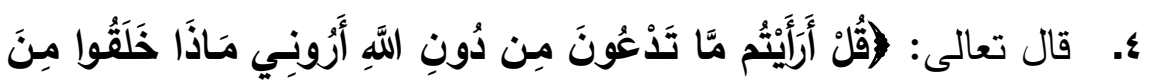

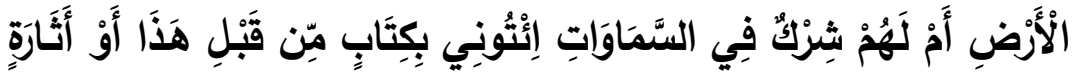

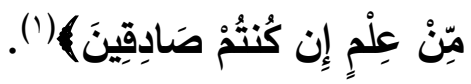

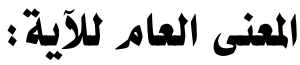

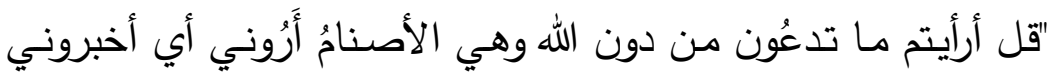

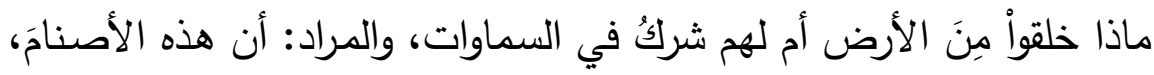

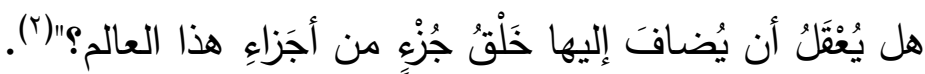

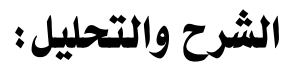

يظهر في الآية الكريمة دور الاستفهام والأمر في تتبيه المتلقي على

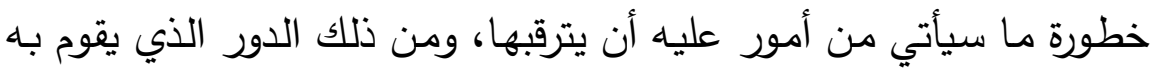
الخطاب في هذه الآية من أساليب الإقتاع لما فيه من التتبيه على التناقض لتض التصن

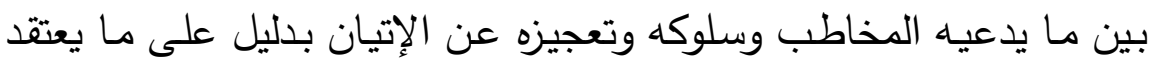

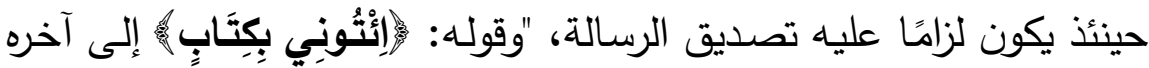
تبكيت لهم بتعجيزهم عن الإتيان بسند نقلي بعد تبكيتهم بالتعجيز عن الإتيان بسند عقلي فهو من جملة القول، أي: ائتوني بكتاب إلهي كائن لإمِّن قَبْْلِ هَذَا الكتاب، أي القرآن، الناطق بالتوحيد وإبطال الثرك دال على صلى صحة

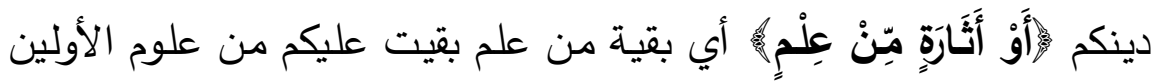

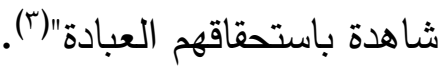

$$
\begin{aligned}
& \text { (1) الأحقاف: الآية (ع). }
\end{aligned}
$$

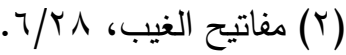

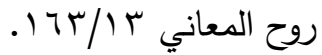




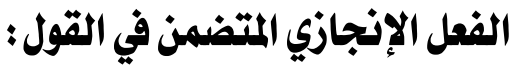

"في هذه الآية قوة التسجيل على المشركين بالعجز، وفي ذلك لفتهر

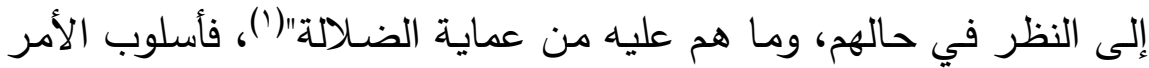

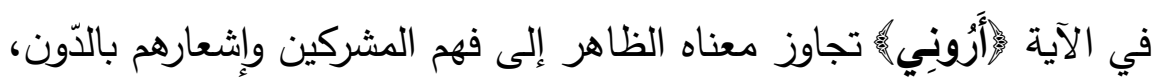

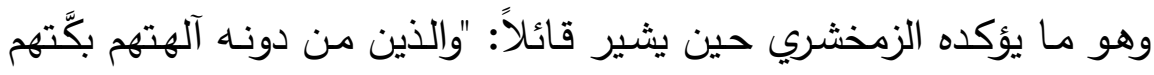

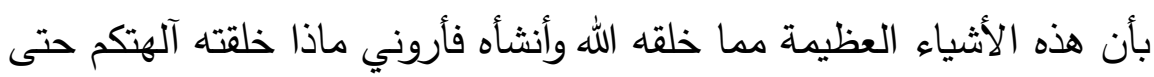

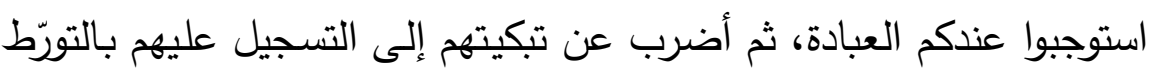

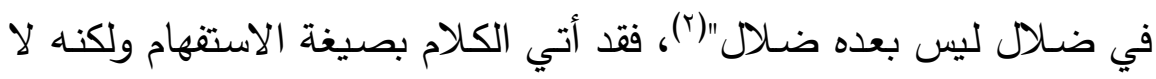

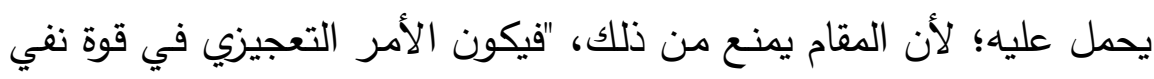

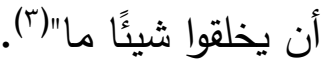

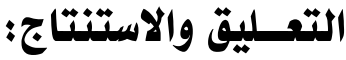

لعل الأشياء المسئول عنها في هذه الآيات تُعد من البديهيات التي لا

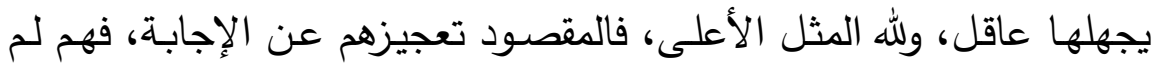

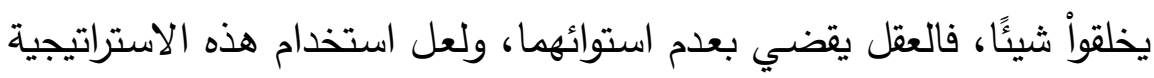

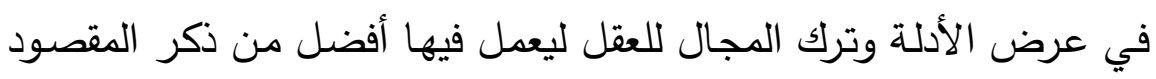

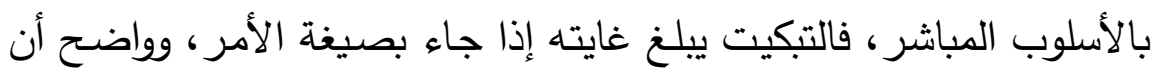

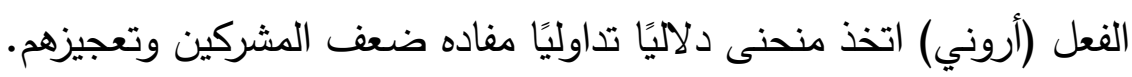

(1) من بلاغة النظم العربي: دراسة تحليلية لمسائل علم المعاني، عبدالعزيز عبدالمعطي

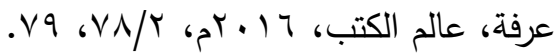

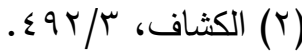

$$
\begin{aligned}
& \text { (r) التحرير والتتوير، r ro/r) }
\end{aligned}
$$




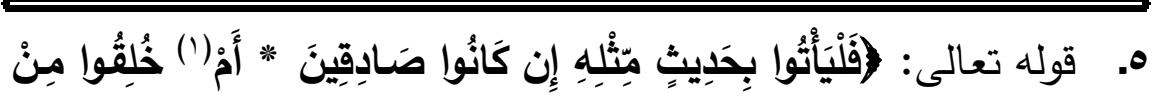

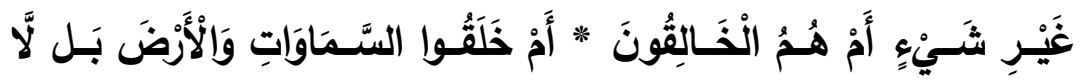

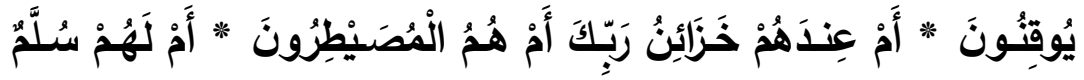

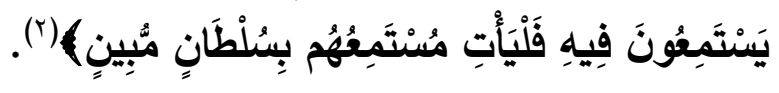

\section{المعنى العام لملآيةة:}

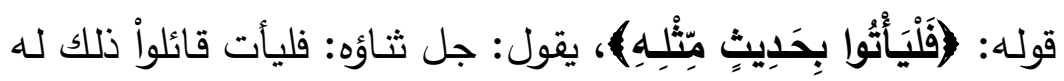

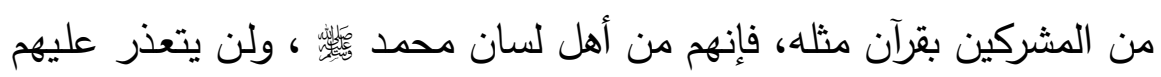

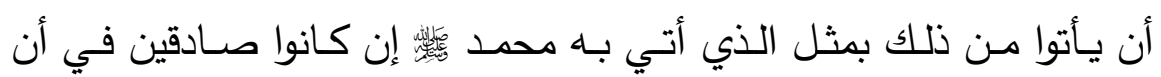

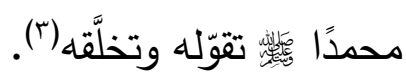

\section{الشرح والتحليل: - | (الشيل}

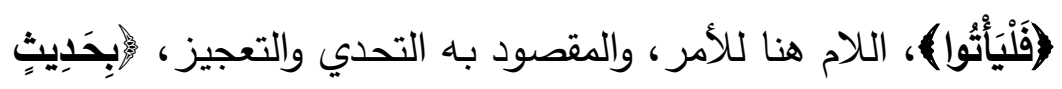

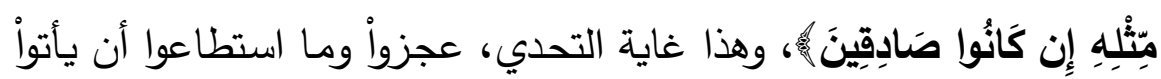

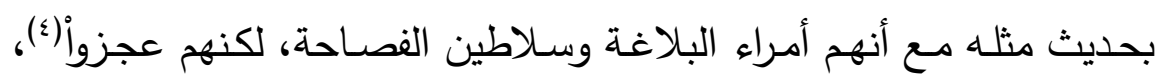

(1) أمْ المنقطعة: أم نوعـان: متصـلة ومنقطعـة، فالمتصـلة تربط مـا قبلهـا بمـا بعدها،

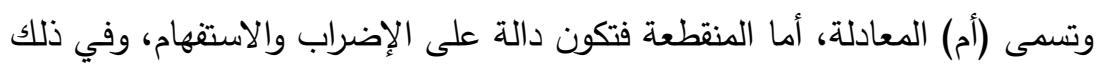

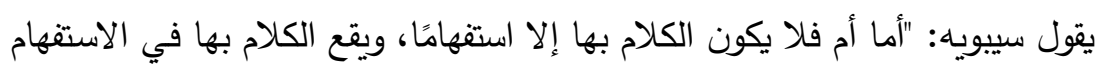

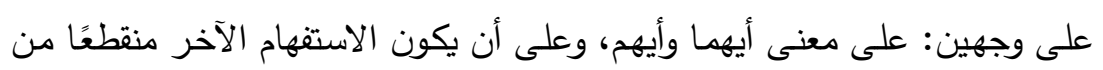

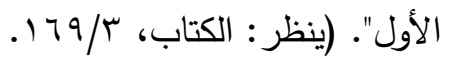

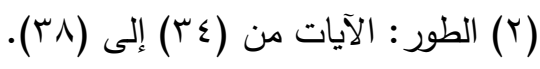

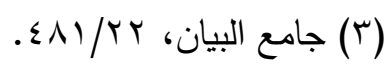

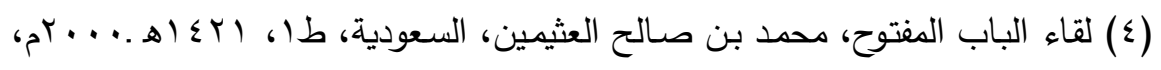

$$
.17 \% / \Lambda
$$


يؤكد هذا المعنى ابن عاشور في قوله: "ولام الأمر في (فَلَيَأْتُوا) مستعملة

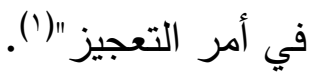

ولقد شكلت مجموعـة الآيـات مـن الآيـة (· ب) إلى (r) ) مـن سورة

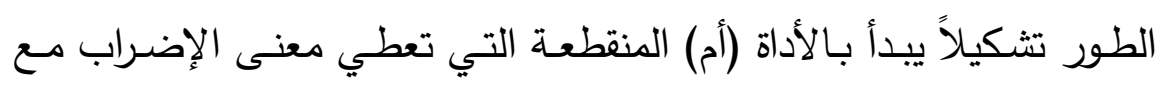
الاستفهام، وكل آية "إضراب انتقالي إلى إبطال ضرب آخر من شبهتهم في إنكارهم البعث"(r)، والآية الكريمة تحمل في طياتها إضرابين مع استفهاميين: وذلك بأن المحاججة معهم تستتطقهم، هل خلقواً من عدم، أم أنهم أوجداً أنفسهم بأنفهه "ووجودهم هكذا من غير شيء أمر ينكره منطق الفطرة ابتداءً

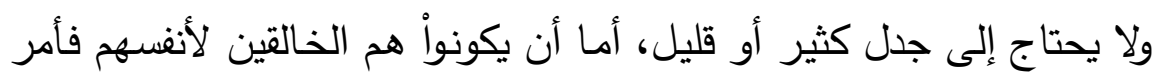
لم يدَّعوه ولا يدّعيه مخلوق، وإذا كان هذان الفرضيان لا يقومان بحكم منطق الفطرة، فإنه لا يبقى إلا الحقيقة التي يقولها القرآن الكريم، وهي أنهم جميعًا

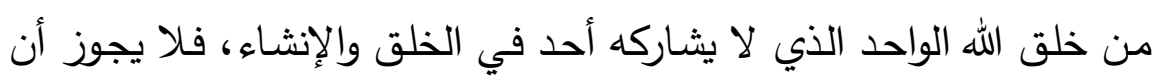
يشاركه أحد في الربوبية والعبادة"(؟).

ويلحظ أن التعبير التعجيزي جاء مصدرًا بـ(أم) المنقطعة الدالة على لهى الاستفهام والإضراب، وجيء بالفعل (خلقواً) مبنيًا للمجهول، ولعل فيه دلالة على عدم امتلاكهم لأمرهم، وجاء التعبير بقوله (شيء) النكرة، ليعطي دلالة

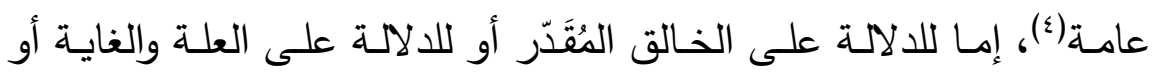
الحيّ، فهم لا يؤمرون ولا ينهون كالجمادات، ثم جاء التعبير الثاني لُأَمْ هُمُ

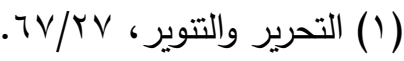

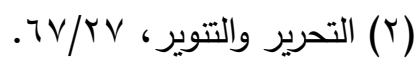

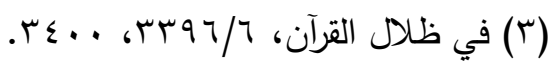

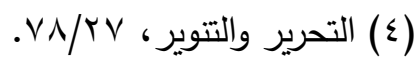




\section{الأفعال الكلامية في آيات التعجيز في القرآن الكريدر دراسة تداولية}

الْخَالقُونَّهُ، والتعبير فيـه يخاطبهم مخاطبة الغائب، ولعل في ذلك تهكمًا وتعجيزًا لهه.

\section{الفعل الإنجازي المتضمن في القول:}

يبدو أن فعل الأمر في (فَََْأْتُوا) قد حمل قوة إنجازيـة فعلية دل فيها

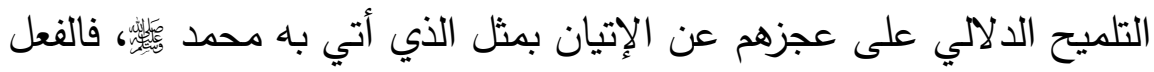
الإنجازي ينقل الكلام من حدوده الضيقة إلى آفاقه البعيدة، التي تتطلب طاقة ذهنيـة عاليـة من الكفايـة التداولية، وقد حدد السياق طبيعـة القوة الكلاميـة المتضـــنة، فـالمتكلم هـو الله ـ عـز وجـل ـ والمخاطب هـم المشـركون، هـذا السياق يجعل الحدث غير اللفظي للفعل (افعل) يفيد التعجيز وهي الدلالـة المدركة على مستوى هذا الحدث.

وقد أتت نمطية التعجيز ضمن النسق الحواري العام في الكتاب العزيز

موافقة لعادة العرب في تخاطبهم، ولخصوصسية لسـانهم، واستوفى المـلى . عـز وجـل ـ في التراكيـب اللغويـة المسـعملة لغـرض الإقنـاع كـل الأشـكال اللسانية الممكنة التي نعرفها، والتي لا نزال نستكثفها، بقدر ما أتُيح لنا من فهم لكتاب الحق ـ سبحانه .، قول الإمـام الزركثي في نص مؤبِّسٍ لقاعدة معرفية تداولية: "... فالمائل إلى دقيق المحاجة هو العاجز عن إقامة الحجة بالجليل من الكلام، فإن من استطاع أن يفهم بالأوضح الذي يفهمه الأكثرون لم ينحط إلى الأغمض الذي لا يعرفه إلا الأقلون، ولم يكن ملغزًا، فأخرج تعالى مخاطباته في مُحاجة خلقه في أجَلِّ صورة، تشتمل على أدق دقيق؛ 
لتفهم العامة من جليلها ما يقنعهم ويلزمهم الحجة، وتفهم الخواص من أثنائها ما يوفي على ما أدركه فهم الخطباء" (1).

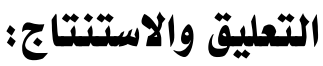

أ ) وقعـ سـرية المشركين المستمرة مـن آيـات القرآن الكريم إلى إعـادة

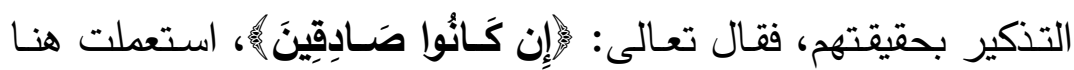

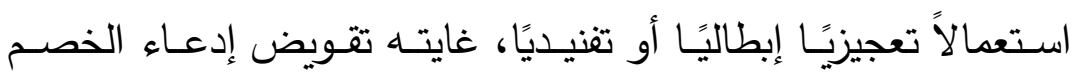
(المشركون) وتبكيتهم.

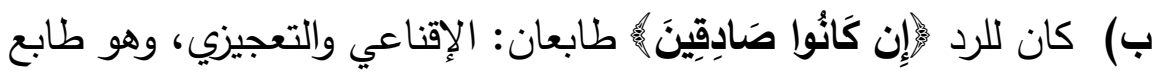
يومئ إلى سد باب الحوار وإغلاقه نهائيًا لاستشعارهم ضـف موقفهم

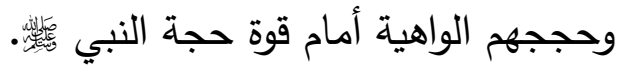

\section{تعقيب عــاهر على هذا المبحث:}

بهذا الذي ذُكر من آيات تحمل أسلوبي الأمر والاستفهام تبين الآتي:

ا. أصبح من الخطأ اعتقاد التطابق بين نظام المعاني ونظام المباني، أو تقييد المباني مبنى مبنى بالدلالـة على معنى معنى فإننا نفترض أن

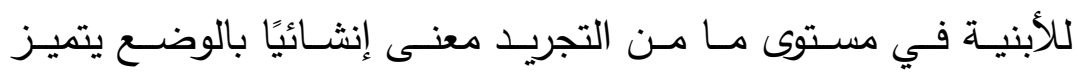
بخصـائص تخاطبية مجردة ومرشحًا لأداء عمل لغوي ما يوافق معناه الإنشائي الوصفي أو يفارقه بقرينـة أو علاقة من العلاقات التي تيمِّر الانتقال من الوضع إلى غير ما يدل عليه الوضع.

(1) البحر المحيط في أصـول الفقـه، الزركثـي، تحقيـق: عبـدالقادر عبـدالله العـاني،

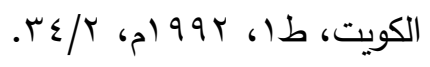


r. إذا كان الفعل اللغوي المباشر هو الذي يؤديه الأمر أو الاستقهام، فإن

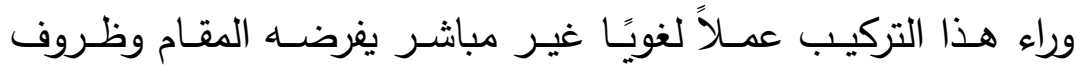

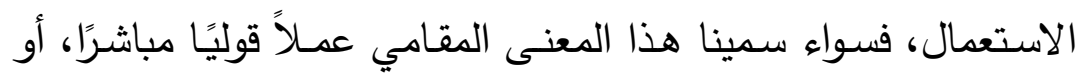
عملاً لغويًا غير مباشر ، أو عملاً تخاطبيًا على الحقيقة، أو معنى أولاً،

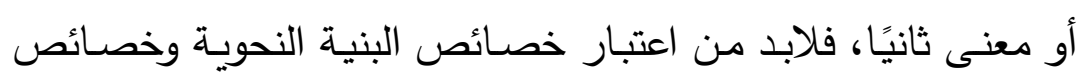

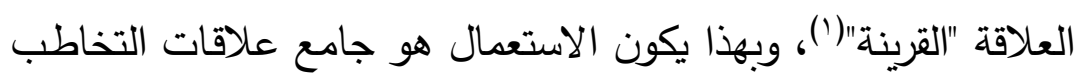
والأحوال المقامية.

(1) ينظر : إنثـاء النفي وشروطه النحويـة والدلاليـة، د. شكري المبخوت، مركز النشر

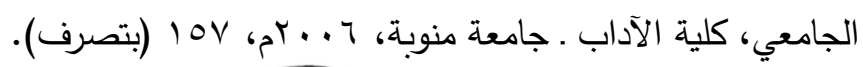




\section{الخاتمــــة}

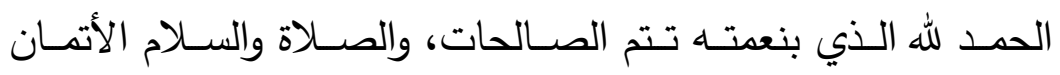
الأكمالان على صاحب الثفاعة سيدنا محمد لئل وعلى آله وصحبه أجمعين.

\section{وبعد 666}

فبعد أن عشنا في رحاب تلك البساتين الندية، والنفحات الإلهية، مـع كتاب ربنا ـ سبحانه وتعالى ـ من خلال تلك الآيات المباركات مقامًا ودراسة نظميـة، عرضـت في دراستي الجانب النظري لأفعـال الكـلام والتداوليـة من ونـ الإرهاصـات الأولى التي دفعت بالبحث اللغوي إلى إيجاد مستوى ثالث بعد مسـتويـ التركيـب والدلالـة، ومـرورًا بمرحلـة المفهوم والنشـأة، ذاكرة اللبنـات الأولى التي شكلت صـرح هذا العلم في الفلسفة عند كل مـن (أوستين)، و(سيرل)، ثم ذكرت الجهود العربية الحديثة في إثراء هذه التداولية، فكان هذا

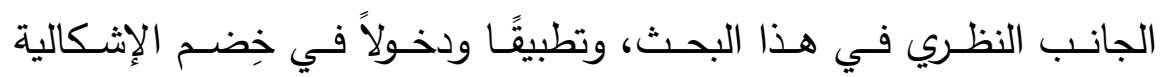
المطروحسة للدراسـة، تعاملـت مـع الـص القرآنـي وارتأيــت أن تكـون آيـات التعجيز خطابًا تُطبق عليه تلك المرتكزات لهذه النظريـة وللأفعال الكلاميـة

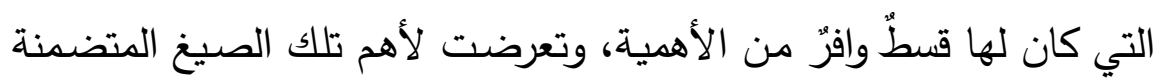
لأفعال الكلام (أسلوب الأمر والاستفهام)، ولم أغفل في دراستي دور السياق؛

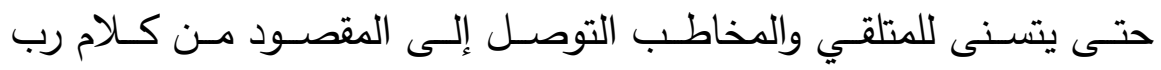
العالمين.

\section{وما يمكن استخلاصه من هذا البحث من نتائج، هي:}

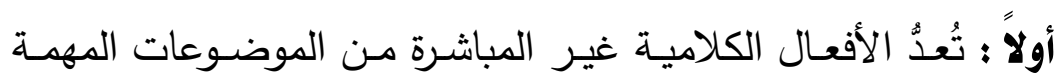
التي أسست لظهور علم التداولية في العصر الحديث، وهي الأفعال التي 
يكون لها إنجاز دلالي يقتضيه المقام أو السياق، فيخرج الملفوظ من معناه الحرفي إلى معنى آخر هو المقصود، يعتمد تفكير العقل والبرهان والحجة

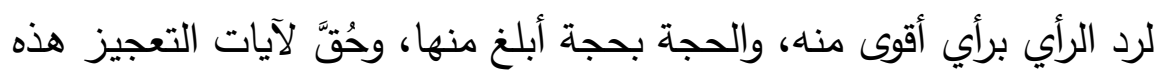

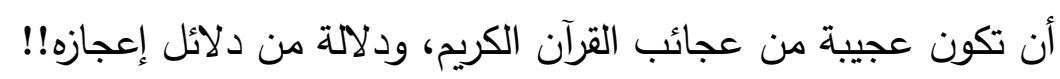
ثانيًا : أن التلميح بالأفعال الكلامية غير المباشرة تتعدد فيه النظرة العميقة للفعل في مقامه السياقي، ومن الطبيعي ألا يسجِّل القرآن الكريم كل مراحل الحوار تسجيلاً كاملاً كما سجلت أدوات التسجيل، فذلك مما لا تقبله بلاغـة القرآن، ولا يحتمله إيجـازهُ وإعجـازْه، وإنمـا يمسك القرآن مـن الموقف الحواري بالعناصر الحية منه، وبالمشاهد البارزة فيه، مما من شأنه أن يُجَلِّي الموقف ويحدد معالمه، ويكثف حقيقته، ثم يكون للناظر بعد ذلك أن يمـأ الفراغات ويلونها بما يسعفه إدراكه، ويمده بـه خياله. وهذا الأفق لا يتحصَّل بهذا العمقي لولا النظم القرآني البديع. ثالثًا : قوة الفعل الكلامي .كما بيَّنه أوستين ـ هو كل فعل كلامي دلَّ على المعنى بأسلوب غير مباشر ؛ وذلك بخروج اللفظ من معنـاه ودلالته الحقيقية إلى معنى آخر هو المقصود الدلالي من هذا القول، كخروج الأمر

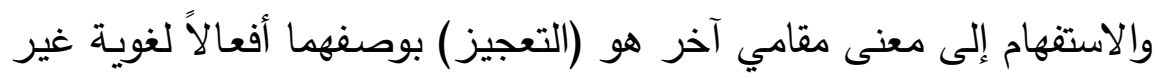

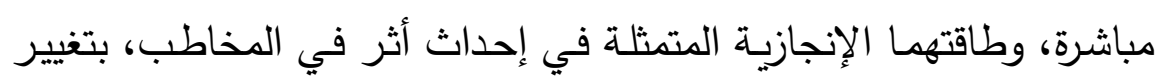
سلوك، أو تهذيبه، أو العدول عن شيء آخر بالالتزام بالمطلوب.

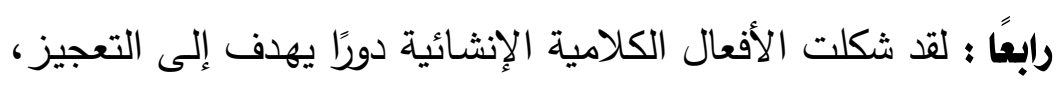
وهذا مـا يـدل على أن الخطاب القرآني فيـه مـن أسـاليب الحـوار ومظـاهر التواصل ما يعجز الدرس الحديث عن الإلمام بها، وكلها "تجسد الاستراتيجية الإقناعية والمنهجية المثلى في التحاور، حتى يتسنى للطرف الآخر استيعاب 
الآليات وتفهم الخطاب، ومن ثم تبني الاعتقاد، وهي أساليب متصلة بمعاني أفعال الكلام غير المباشرة"(1).

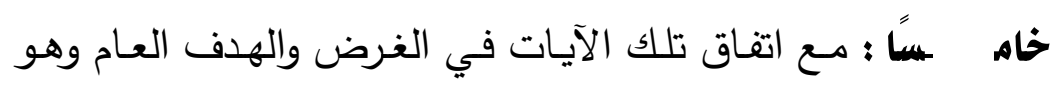
التعجيز ، إلا أننا وجدنا اختلافًا في المقامات، فتارة يكون المقام طلب تبديل القرآن، أو تغييره، وتارة يكون احتقارًا للمؤمنين وسخرية منهم، وتارة يكون تجهمًا وعبوسًا وشرًا يبدو على وجوه الكافرين، وتارة يكون بمحاولة الهروب بتعجيز المؤمنين بطلب الإتيان بآباء الكفار ... وهكذا، ثم وجدنا التلاؤم

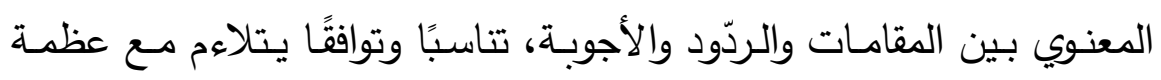

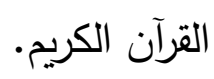

سادساً : يلاحظ أن ردود أفعال الكافرين في كل الآيات دارت حول:

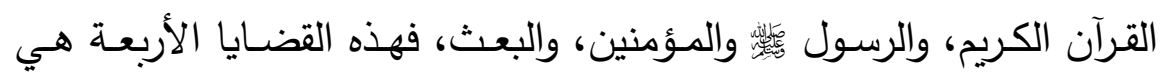
شــلهم الثـاغل، وعليهـا دارت فكرة البحـث، وراء ذلك إلمـاح إلى جـوابهم المتوقع ورد فعلهم الخبيث وهو التعجيز • سابعًا : ليس المقصود بالتعجيز إثبات العجز للخلق لذاته، من غير ترتب مطلب على هذا العجز، بل المقصود لازم هذا التعجيز وهو: إقامـة

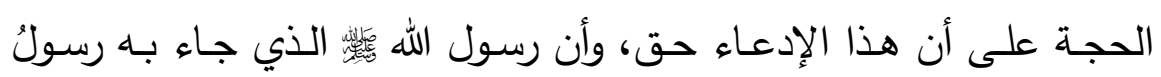
صـدقٍ، فينتقل النـاس من الثـعور وعجزهم إزاء تلك الآيـات إلى شـعورهم

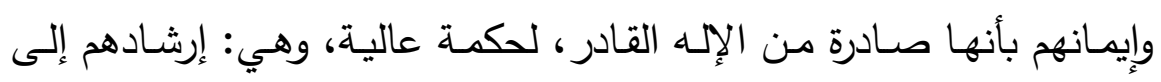
تصديق من جاء به، ليسعد في الدنيا والآخرة.

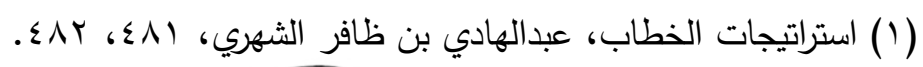




\section{الأفعال الكلامية في آيات التعجيز في القرآن الكريدر دراسة تداولية}

ثامنًا : لو نصت آيات الذكر الحكيم على وجوه التعجيز لكفر جاحدها أو الثالك فيها، وهذا من رحمة الله تعالى بنا، أن القرآن الكريم لم يتركنا في حيرة، بل وجها في الآية بعد الآية إلى تدبر مواطن التعجيز التي تقود إلى إدراك ما لا يتتاهى فيرى كل متدبر حسب سلامة فطرته وقوة بصيرته، فقد يدرك الباحث وجهًا من وجوه التعجيز ، بينما يدرك أهل عصر ما لا يدركه غيرهم في عصر آخر (').

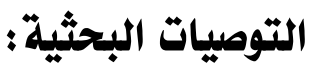

1. توصي الباحثة إلى إعادة قراءة التراث من منظور حديث، لمعرفة موقع ومكانة منجزات التراث اللغوي العربي من الفكر اللغوي المعاصر . r. توظيف المستوى التداولي في تعليم اللغـة العربية للناطقين بها، وغير الناطقين بها؛ لفهم الإعجاز اللغوي للقرآن الكريم من خـلال السياق،

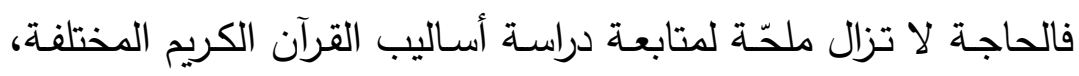
حتى يغدو نبراسًا في محاكاة تراثنا اللغوي، وهاديًا إلى تبسيط فنون القول المختلفة.

وبهذا أكون قد انتهيت من هذا البحث، وهو عمل إنشـائي وصف بالنسيان والنقّصان، فاله أسأل أن تكون الهنات والعثرات أقل مما قد يُسيء وهيء أو يُصَـنِف عملي بالأخطـاء، فـاللهم لك الحمد كمـا يليق بوجهك وعظيم سلطانك على ما كل ما أنعدت به علينا، والله من وراء القصد وهو الهادي لهاءي إلى سواء السبيل.

\section{وآخر دعوانا أن الحمد للّه رب العالمين.}

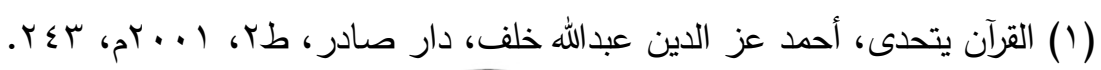




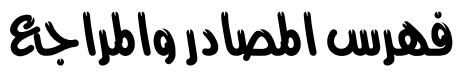

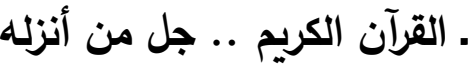

1. الإتقان في علوم القرآن، السيوطي (عبدالرحمن بن أبي بكر جـلال

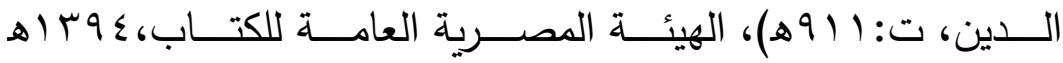
$. \wedge ، V / \varepsilon$ م $) \backslash 9 V \varepsilon$.

r. الإتيان والهجيء فقه دلالتهما واستعمالهما في القرآن الكريم، محمود

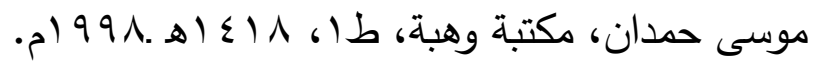
r. أحكام القرآن، الجصاص (علي بن علي أبي بكر الرازي، ت: • • آته)،

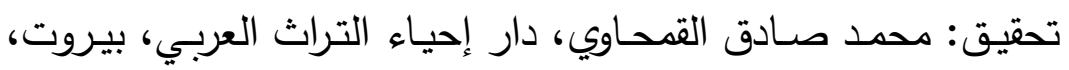
. $1 \leq 10$

ع. إرشاد العقل السليم إلى مزايا الكتاب الكريم، أبو السعود (محمد بن العبا.

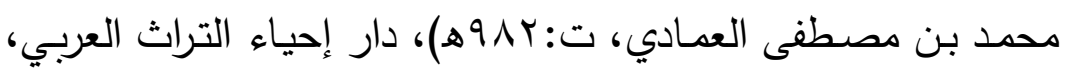

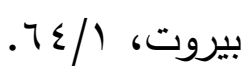

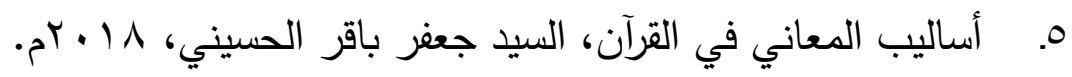
T. أسـباب نـزول القـرآن، الواحـدي، تحقيـق: عصــام بـن عبدالمحسـن

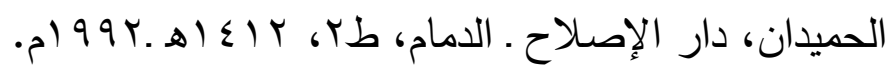

V . استاطيقا الإثارة: دراسة بلاغية سيميوطيقية، مصطفى السعدني، دار المعارف، الإسكندرية، مصر ، (د.ط)، ؛ 99 ام.

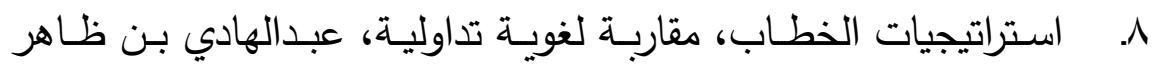
الثهري، دار الكتاب الجديد المتحدة، طا، ـ ـ. بام. 


\section{الأفعال الكلامية في آيات التعجيز في القرآن الكريدر دراسة تداولية}

9. الاسـتلزام الحـواري في التـاول اللسـاني مـن الـوعي بالخصوصـيات

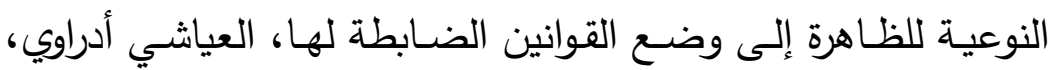

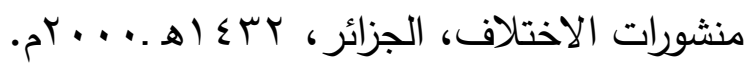
• ا. الأسـلوبية والأسـلوب، عبدالسـلام المسـدي، الـدار العربيـة للكتــاب،

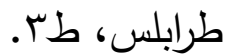

ا ا. إعجاز القرآن الكريم بالصّرفة: دراسة ناقدة، محمود توفيق محمد سعد، .ه I $\leqslant Y \leqslant$

r. إعجـاز القرآن، محمد بن الطيب أبو بكر البـاقلاني، دار المعـارف،

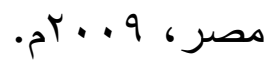

سا. الإعجاز اللغوي والبياني في القرآن الكريم، جمع وإعداد: علي بن نايف الشحود.

ع ا. إعراب القرآن الكريم وبيانه، محيي الدين درويش، دار الإرشاد، حمص . سوريا، طع.

1. أعـلام النبـوة، المـاوردي (أبـو الحسـن علـي بـن محمـــ البصـري،

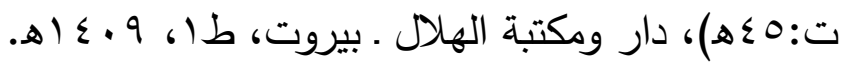

ج ا. آفاق جديدة للبحث اللغوي المعاصر، محمود أحمد نحلة، دار المعرفة

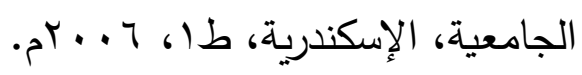

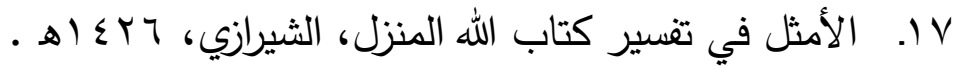


1 ا. الإنثـاء في العربيـة بين التركيب والدلالـة: دراسـة نحويـة تداوليـة، د.

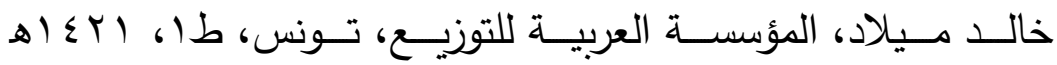

$$
\text { . }
$$

9 1. إنشـاء النفي وشـروطه النحويـة والدلالية، د. شكري المبخوت، مركز

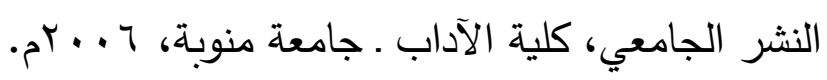

• r. أنوار التنزيل وأسرار التأويل، البيضاوي (ناصر الدين أبو سعيد عبدالله

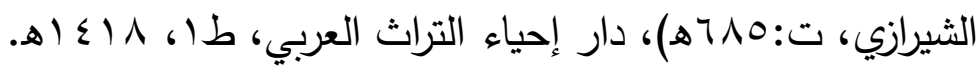

ا r. الإيضـاح في علوم البلاغة المعاني والبيان والبديع، القزويني (محمد

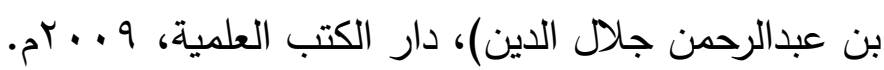

r.r. البحر المحيط في أصـول الفقـه، الزركثي (أبو عبدالله بدر الدين،

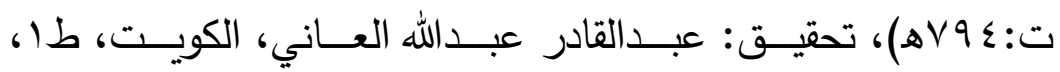
. $) 99 r$

r r. البحر المحيط في التفسير، أبو حيان (محمد بن يوسف بن علي أثير

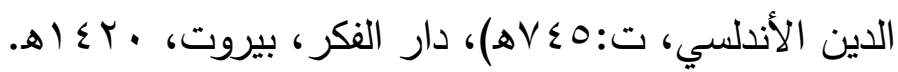
ع ז. بحوث في الإعجاز والتقسير في رسائل النور، أحمد خالد شكري،

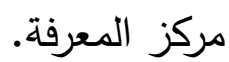

ه. البرهان في علوم القرآن، الزركشي، تحقيق: محمد أبو الفضل إبراهيم،

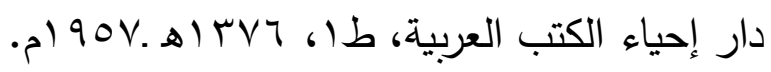

جr. البلاغـة العربيـة أصـولها وامتداداتها، محمد العمري، أفريقيـا الشـرق،

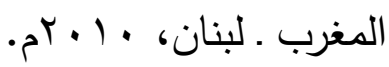




\section{الأفعال الكلامية في آيات التعجيز في القرآن الكريدر دراسة تداولية}

rV

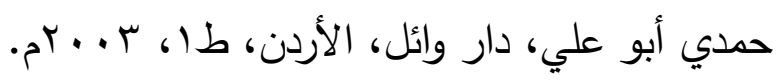

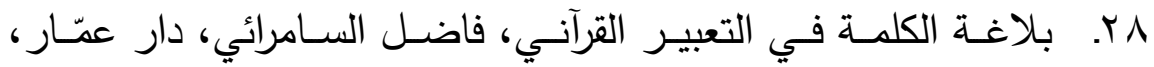

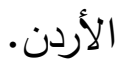

9. . البلاغة والأسلوبية نحو نموذج سيمائي لتحليل النص، هنري بليث،

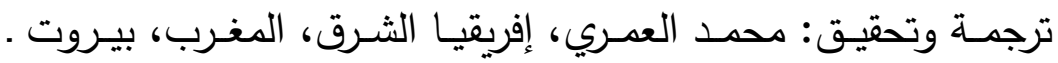
لبنان،

•r. بيان إعجاز القرآن (ضمن ثلاث رسائل في إعجاز القرآن)، الخطابي،

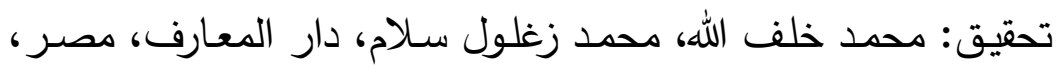

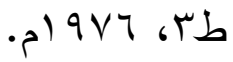
اr. البيان والتبيين، الجـاحظ (عمرو بـن بحر بـن محبوب أبو عثــان،

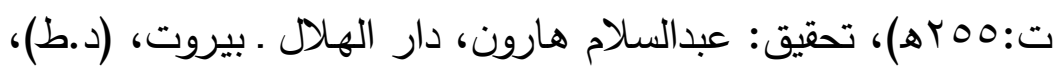
. ه I $\leqslant r$

rr. التبيان في أقسام القرآن، ابن القيم (محمد بن أبي بكر بن أيوب بن

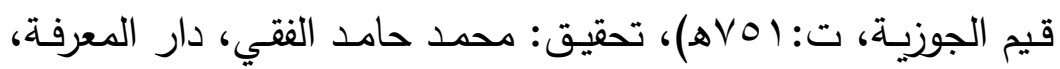

$$
\text { بيروت . لبنان. }
$$

بr. التحريـر والتتـوير ، الطـاهر بـن عاشـور (محمــ الطـاهر بـن محمــ

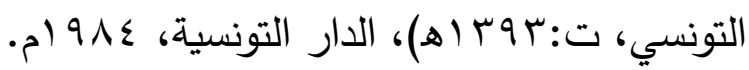

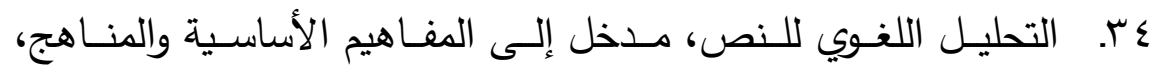
كلاوس برينكر ، تحقيق: سعيد حسن بحيري، مؤسسة المختار للنشر ،

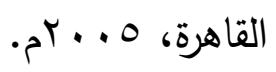


هr. التداولية: البعد الثالث في سميوطيقا موريس من اللسانيات إلى النقد الأدبي والبلاغة، عيد بلبع، مجلة فصول، مصر، 0 . . بام.

بس. التداوليـة، جورج يـول، ترجمـة: قصسي العتابي، دار الأمـان، الربـاط،

$$
\text { ط) }
$$

rV

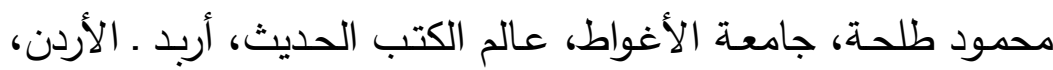

$$
\cdot 4 r \cdot 1 r
$$

مَ. التداولية عند العلماء العرب: دراسة تداولية لظاهرة (الأفعال الكلامية) في التـراث اللسـاني العربـي، د. مسـعود صـحراوي، دار الطليعـة،

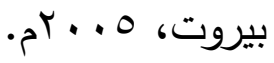

q. التسـهيل لعلوم التنزيل، محمد بن أحمد بن جزي الكلبي أبو القاسم (ت: (1) (ه)، دار أم القرى، مكة المكرمة، (د.ط).

• ع. تقفير القرآن (سورة النمل) محمد بن صالح العثيمين، مؤسسة الثيخ

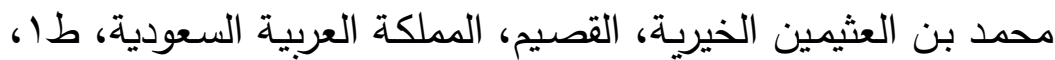
ד

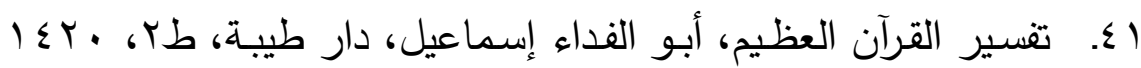

$$
\text { . }) 999 \text {. }
$$

Y

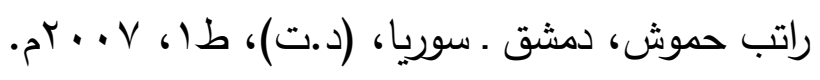

بع. تقفير المراغي، أحمد مصطفى المراغي، مصطفى البابي الحلبي،

$$
\text { ط }
$$




\section{الأفعال الكلامية في آيات التعجيز في القرآن الكريدر دراسة تداولية}

ع ع. تقفسير مقاتل بـن سليمان، (أبو الحسين مقاتل بـن سليمان الأزدي،

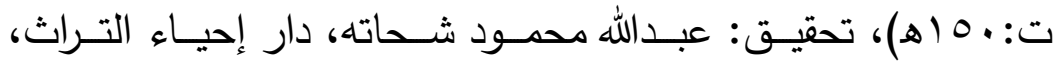

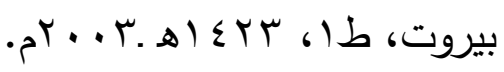

هـ. تقسير من وحي القرآن، محمد حسين فضل الله، دار المـلاك، طب، - ) 991

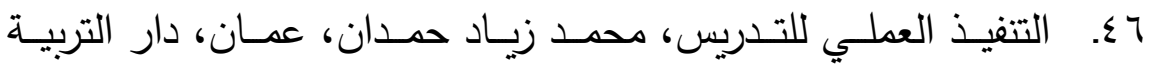

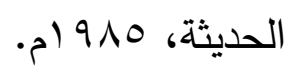

ع V . التواصـل اللسـاني والثـعرية، الطـاهر بو مزبر ، الدار العربية للعلوم،

$$
\text { ط }
$$

^ء. جامع البيان في تأويل القرآن، الطبري، (محمد بن جرير بن يزيد بن

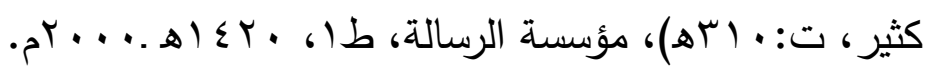

9. الجامع لأحكام القرآن، القرطبي، (أبو عبدالله محمد بن أحمد بن أبي

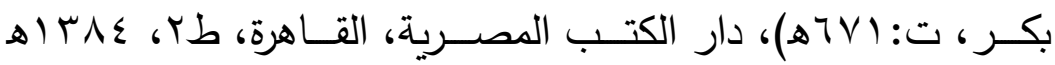
. ) $97 \varepsilon$.

•. الجــدول فـي إعـراب القـرآن، محمــود بــن عبــدالرحيم صــافي

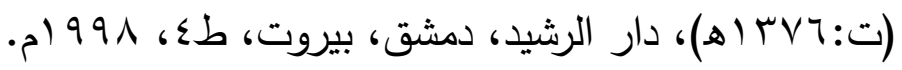

0. جمهرة الأمثال، أبو هلال العسكري، (أبو هلال الحسن بن عبدالله، ت:00 بهـ)، دار الفكر ، بيروت.

ror حاشية محي الدين شيخ زاده على تفسير القاضسي البيضـاوي، محي الدين شيخ زاده، دار الكتب العلمية، 1 . . rم. 
r. الحجاج في القرآن من خلال خصائصه الأسلوبية، عبدالله صولة، دار

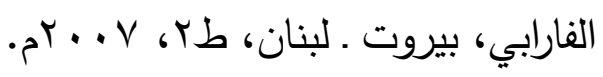

ع. الحوار في القرآن، محمد حسين فضل الله، دار الملاكَ للنشر، لبنان،

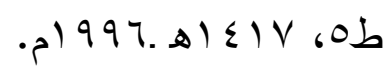

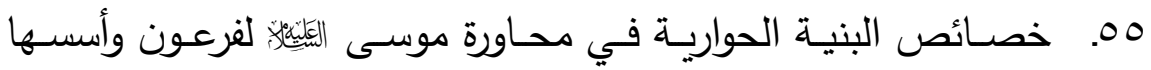
الحجاجية، د. بـو شعيب بـن مسعود راغين، جامعـة طيبـة، المدينـة المنورة.

07. خصـائص التراكيـب: دراسـة تحليليـة لمسـائل علم المعـاني، د. محمد

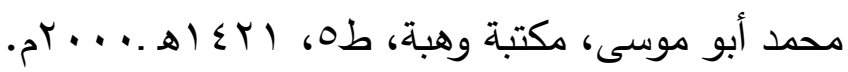
ov . الدلاليات والتداوليات، أشكال الحدود، منشور ضـن البحث اللسـي والسيميائي، طه عبدالرحمن، الرباط، المغرب، طا ، ع 9 (م. ^ه. روح المعـاني في تفسير القـرآن العظيم والسـبع المثـاني، الألوسـي

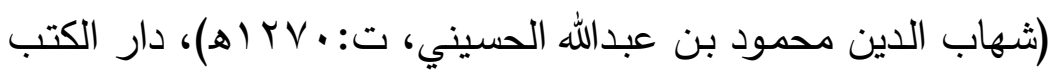

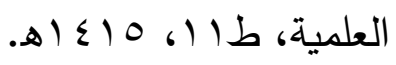

ه. زاد المسـير فـي علــم التقسـير، الجـوزي (جمــال الـدين أبـو الفـرج عبدالرحمن، ت: تهوهـ)، ابن القيم الجوزية، المكتب الإسلامي. • T. السياق والمعنى: دراسـة في أسـاليب النحو العربي، عرفـات فيصـل

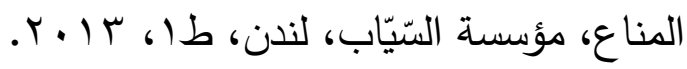
آ. شـرح ابـن عقيـل علـى ألفيـة ابـن مالـك، ابـن عقيـل (عبـدالله بـن

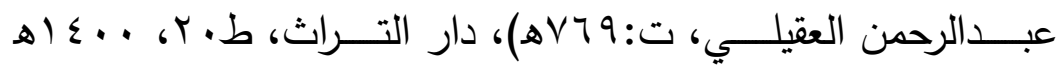
• ค) 91 . 


\section{الأفعال الكلامية في آيات التعجيز في القرآن الكريدر دراسة تداولية}

rا. شرح شافية ابن الحاجب (محمد بن الحسن الرضي الاستراباذي، نجم

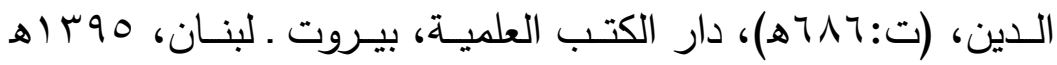

$$
.479 / 4 \text { 6 5) } 980 .
$$

بآ. شـرح شـذور الـذهب، ابـن هشـام (عبـدالله بـن يوسـف بـن أحمـــ، ت: (آحه)، الشركة المتحدة، سوريا.

ـا. الصـاحبي في فقه اللغـة العربية ومسائلها، وسنن العرب في كلامها،

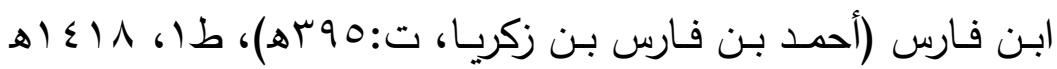
. $99 \mathrm{~V}$.

هـ. صحيح البخاري، البخاري (محمد بن إسماعيل أبو عبدالله)، تحقيق:

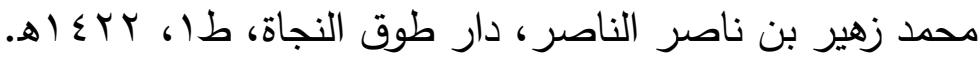
77. صور الأمر في العربية بين التظير والاستعمال، سعود بن غازي أبو

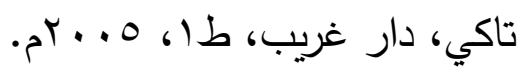

TV. علم اللغة الاجتماعي، محمد حسن عبدالعزيز، مكتبة الآداب، القاهرة،

$$
\text { ط) }
$$

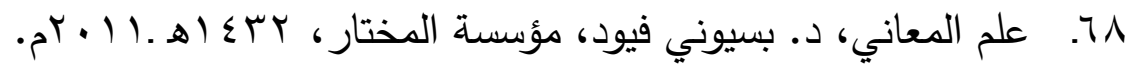
79. علـم المعـاني (في البلاغـة العربيـة)، عبدالعزيز عتيق، دار النهضــة

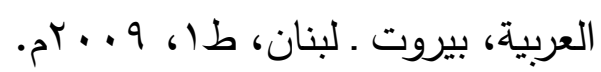

• . . غرائب القرآن ورغائب الفرقان، النيسـابوري (نظام الدين الحسن بن

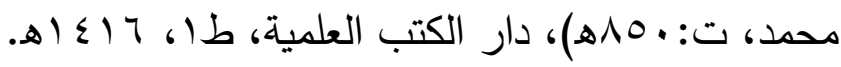




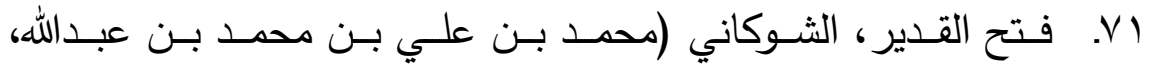

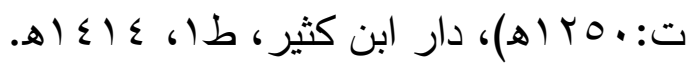

الفعل الكلامسي في سورة الأنفال: قراءة تداولية، حسين جعفر عبيد، جامعة بابل للعلوم الإنسانية.

r.V. الفلسفة واللغة (نقد المنعطف اللغوي في الفلسفة المعاصرة)، الزواوي بغوره، دار الطليعة، بيروت ـ لبنان، طا، 0 ـ. . . . ع V. في تداوليـة الخطاب الأدبـي (المبادئ والإجراء)، نـواري سـودي أبو زيد، بيت الحكمة العلمة، الجزائر، طا لـ ه. في ظـلال القرآن، الثيخ سيد قطب، دار الشروق، بيروت، القاهرة، طVا،

TV. في فلسفة اللغة، محمود فهمي زيدان، دار النهضة العربية، 910 ام.

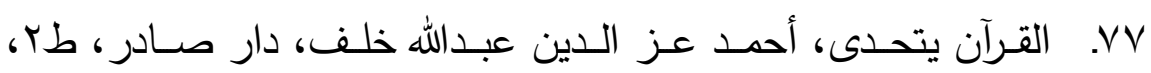
$\cdot r^{2} \cdot 1$

VA . قطـوف دانيـة في علـوم البلاغـة، فـلاح حسن محمد الجبّوري، دار

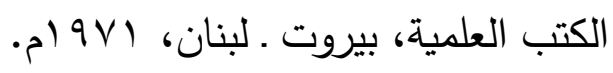

9. قواعد النحو العربي في ضوء نظريـة النظم، سناء حميد البياتي، دار

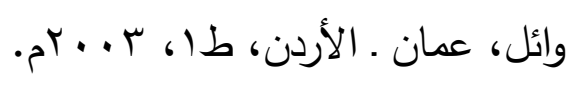

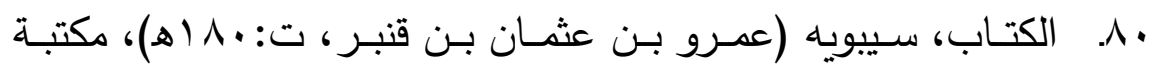

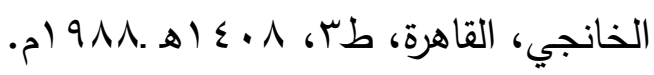




\section{الأفعال الكلامية في آيات التعجيز في القرآن الكريدر دراسة تداولية}

1. 1. الكثاف عن حقائق غوامض التنزيل، الزمخشري (أبو القاسم محمود

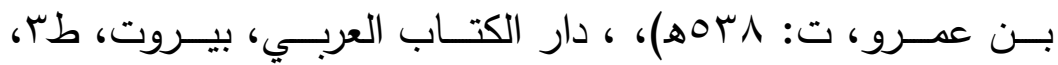

$$
\text { . ) } \varepsilon \cdot V
$$

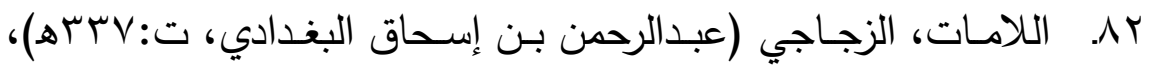

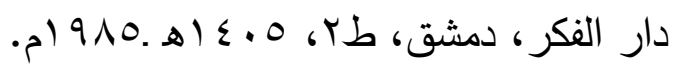

بی. اللام في القرآن الكريم ـ معانيها وعملها، أحمد إسماعيل الوحيدي، دار

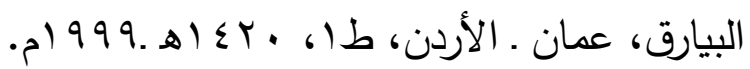

ع. ـ لسـان العرب، ابن منظور (محمد بـن مكرم بـن علي أبـو الفضـل،

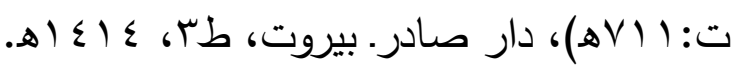

هـ. لسانيات النص (مدخل إلى انسجام الخطاب)، محمد خطابي، المركز الثقافي العربي، الدار البيضاء، المغرب، طاه، (99 (م.

جـ. اللسـان والميزان أو التكوثر العقلي، طـه عبدالرحمن، المركز الثقافي

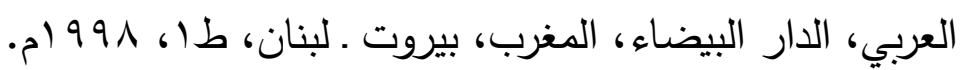

AV

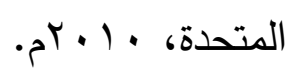

11. لقاء الباب المفتوح، محمد بن صـالح العثيمين (ت: اب ؛ (هـ)، المملكة

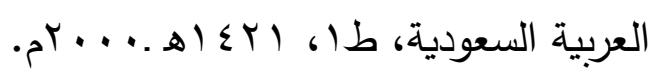

19. مباحث في علوم القرآن، منّاع خليل القطّان، مؤسسة الرسالة، طץ. •9. المثل السائر، ابن الأثير (ضياء الدين بن الأثير، ت:VTr هـ)، نهضة 


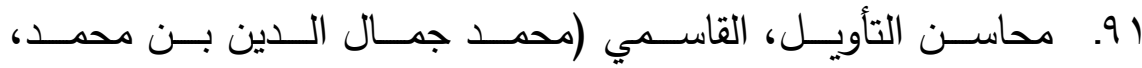

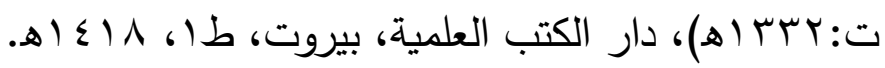
r9. محاضـرات في المدارس اللسـانية المعاصـرة، نعمان بوقرة، منشورات

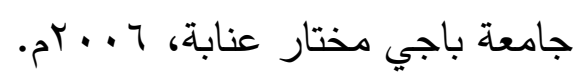

بو. المحرر الوجيز في تقسير الكتاب العزيز ، ابن عطية (عبدالحق بن غالب الأندلسي)، تحقيق: عبدالسـلام عبدالثـافي محمد، دار الكتب

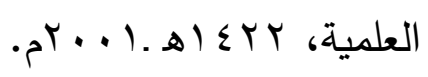

؟. مدخل إلى علم اللغـة النصسي، فولفجـانج هاينـه من وديتر فيهفيجر ،

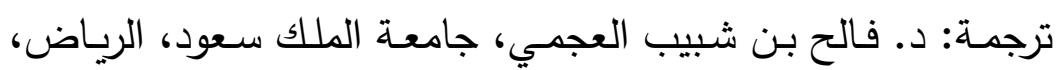

$$
\text { ط ط }
$$

9. مدخل إلى علم النص ـ مشكلات بناء النص ـ زتسيسلاف واورزنياك،

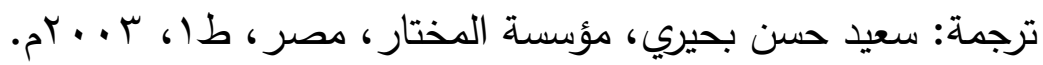
99. مدخل إلى اللسانيات التداولية الجيلاني دلاش، ترجمة: محمد يحياتن، ديوان المطبوعات الجامعية، الجزائر ، (د.ط)، (د.ت).

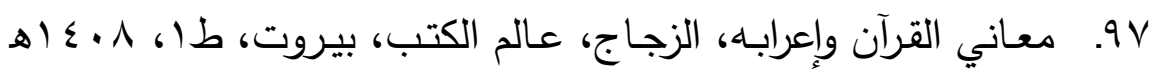
- ค) $9 \wedge \Lambda$.

91. المعجم الأوسط، الطبراني (سليمان بن أحمد بن أيوب، ت: . جسه)،

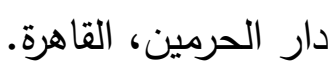

99. علي، دار المدار الإسلامي، ل •. . rم. 


\section{الأفعال الكلامية في آيات التمجيز في القرآن الكريم دراسة تداولية}

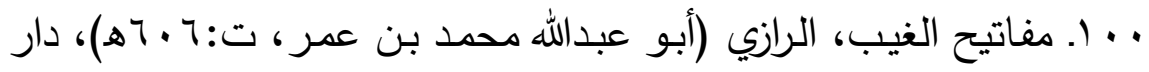
إحياء التراث العربي، بيروت، طץ، • بـ أه.

1 ـ ا. المفردات في غريب القرآن، الأصفهاني (أبو القاسم الحسين بن محمد،

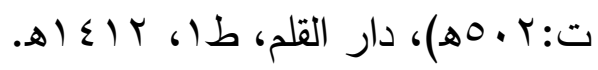

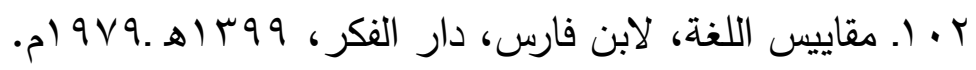

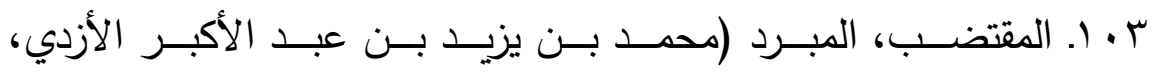
ت:1 ب هـ)، عالم الكتب، بيروت.

ع • ا. مقدمـة في علمي الدلالـة والتخاطب، محمد محمد يونس علي، دار

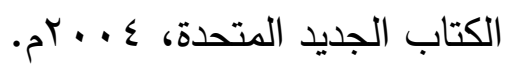

ه ـ ا. مناهل العرفان في علوم القرآن، محمد عبدالعظيم الزقاني، عيسى

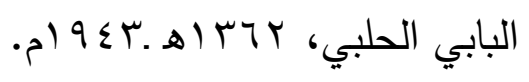

T ـ ا. مـن بلاغـة الـنظم العربـي: دراسـة تحليليـة لمسـائل علم المعـاني،

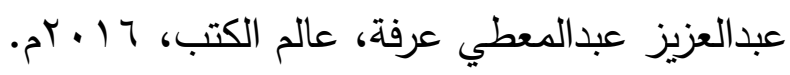

V • ا. من توجيهات القرآن العظيم، محمد عبدالكريم الجزائري، دار المتلقي

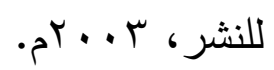

1 • 1. من نحو المباني إلى نحو المعاني (بحث في الجملة وأركانها)، محمد طاهر الحمصي، الناشر: دار سعد الدين، دمشق، طا، بـ +. .بم. 9 ـ ا. الميـزان في تفسير القرآن، الطباطبائي، مؤسسـة الأعلمي، بيـروت، . $1 \leqslant 1 V$ 
•11. نحو النص، اتجاه جديد في الدرس النحـوي، أحمد عفيفي، مكتبـة

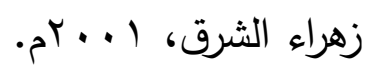

111 إ. نحـو النص (إطـار نظري ودراسـة تطبيقيـة)، عثــان أبو زيـد، عـالم

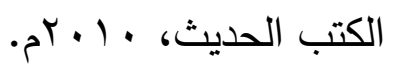

با ا. نـزول آيـات القرآن الكريم وسـوره، أحمـد خالد عمـران سـيح، تقديم ومراجعـة: أحمد محمد مفلح، جمعيـة المحافظـة على القرآن الكريم،

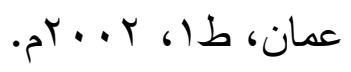

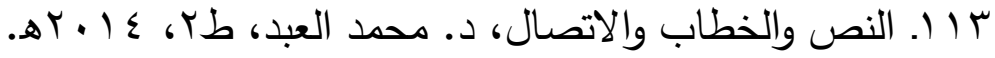
ع إ. نظريـة أفعـال الكـلام العامـة .كيف نتجز الأشـياء بـالكلام، أوستين، ترجمة: عبدالقادر قنيني، الدار البيضاء، إفريقيا الشرق، 99 (م. 11 ا. نظريـة الأفعـال الكلاميـة بـين فلاسـفة اللغـة المعاصـرين والبلاغيـين العرب، طالب سيد هاشم الطبطائي، جامعة الكويت، ؛ 99 (م. ד 11 . الهداية إلى بلوغ النهاية، مكي بن طالب القيسي (أبو محمد مكي بن

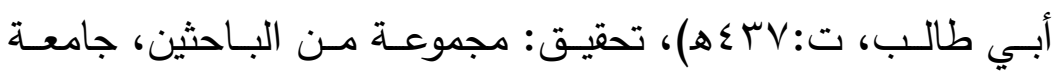

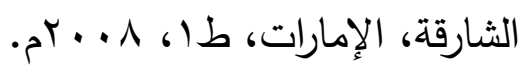

\section{الرسائل الجامعية : - (الجية}

ا. أفعال الكلام في سورة مريخ: دراسـة تداولية، صباح حدادي، وسوسن

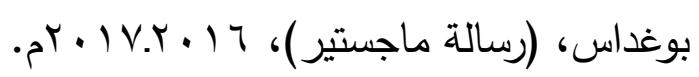

r. الأفعال الكلامية في سورة الكهف: دراسة تداولية، آمنـة لعور ، (رسالة

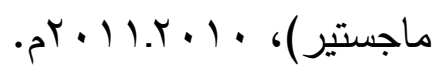




\section{الأفعال الكلامية في آيات التمجيز في القرآن الكريم دراسة تداولية}

r. الأفعال الكلامية في القرآن الكريم (سورة البقرة: دراسـة تداولية)، محمد مدور ، (رسالة دكتوراه)، جامعة الحاج الخضر ، باتتة، با ا ـ بم.

ع. بني الجدل في الخطاب القرآني، خولـة عبدالحميد، (رسالة دكتوراه)،

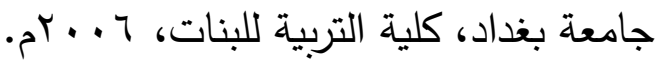

ه. تجليـات مفـاهيم التداوليـة في التـراث العربـي، تقسـير الـرازي لسـورة المؤمنــون أنموذجًا، (رسـالة ماجسـتير)، موسـى جمـال، الجزائـر ، $\cdot p^{r} \cdot q$

T. الجوابات في التعبير القرآني، سعاد كريم خثيف، (رسـالة دكتوراه)،

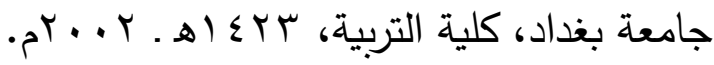

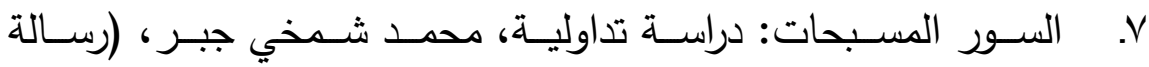

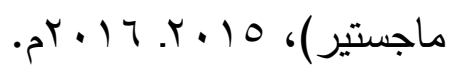

^. لغة الخطاب القرآني في بني إسرائيل: دراسـة أسلوبية دلالية، (رسالة

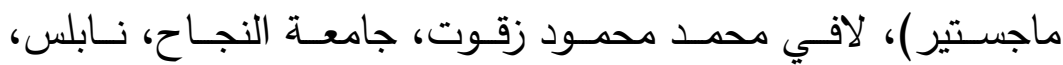
فلسطين.

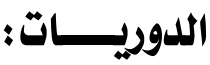

9 . البنيـة الحجاجيـة في القرآن الكريم، (سورة النمل نموذجًا)، الحواس مسعودي، مجلة اللغة والأدب، معهد اللغة العربية وآدابها، ع(Y ( ).

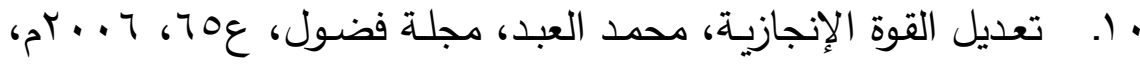
$.1 T V$ 


\section{فهرس الموضوعات}

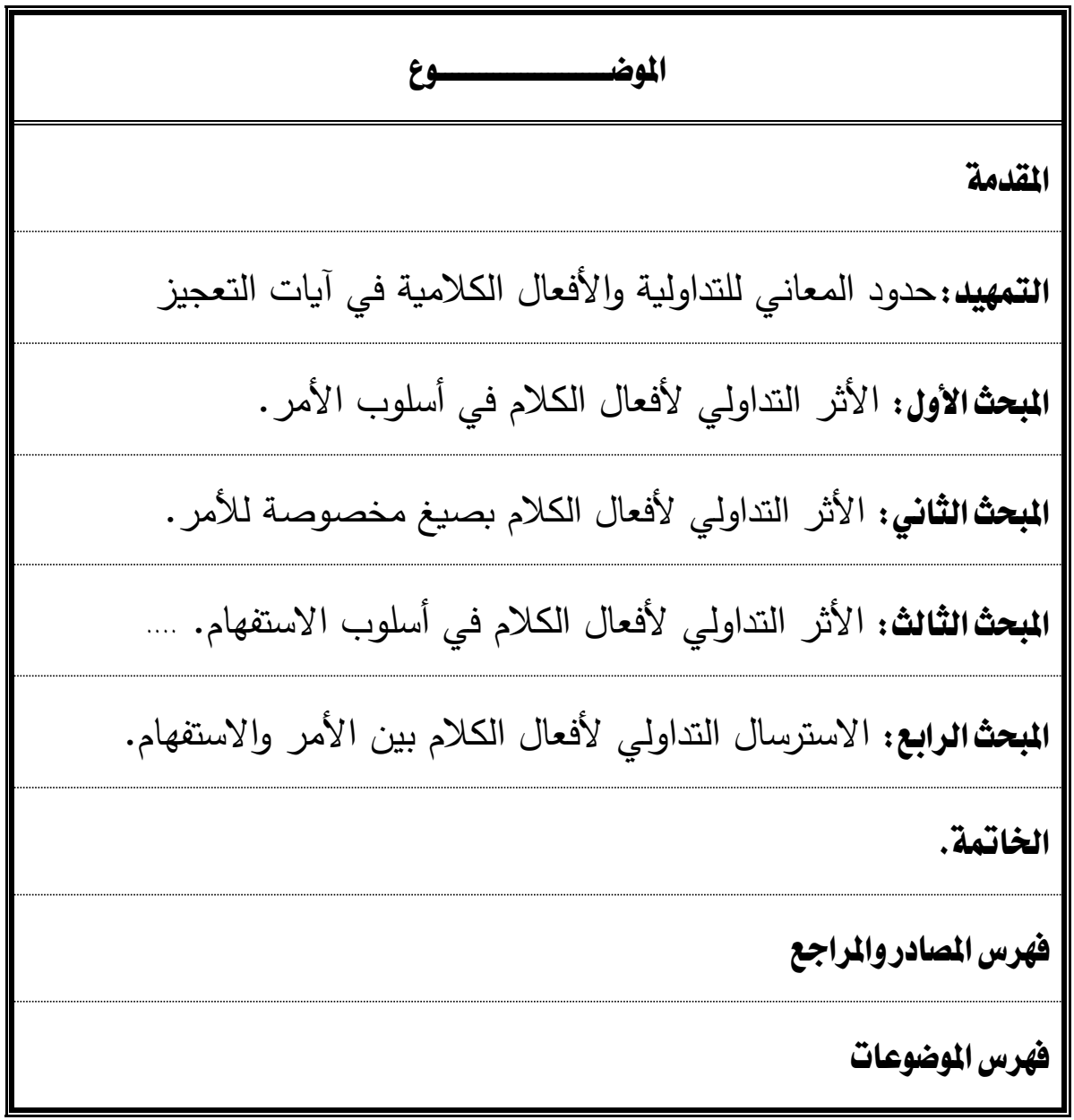


